Geology of the Southern

Salinas Valley Area,

California

GEOLOGICAL SURVEY PROFESSIONALAPAPER 819

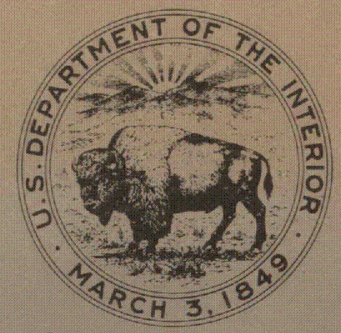

CALIFORNIA INSTITUTE OF

AUG 211974

TECHNOLOGY 
6) 


\section{Geology of the Southern Salinas Valley Area, California}

By DAVID L. DURHAM

GEOLOGICAL SURVEY PR OFESSIONAL PAPER 819

Stratigraphy, structure, and economic geology

of parts of Monterey, San Luis Obispo, and

San Benito Counties

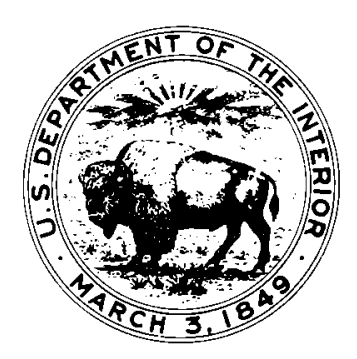

$\overline{\text { UNITED STATES GOVERNMENT PRINTING OFFICE, WASHINGTON : } 1974}$ 


\section{UNITED STATES DEPARTMENT OF THE INTERIOR}

ROGERS C. B. MORTON, Secretary

\section{GEOLOGICAL SURVEY}

V. E. McKelvey, Director

Library of Congress catalog-card No. 74-600020

For sale by the Superintendent of Documents, U.S. Government Printing Office Washington, D.C. 20402 - Price $\$ 4.55 \quad$ (paper cover)

Stock Number 2401-02471 


\section{CONTENTS}

Abstract

Introduction

Location and geologic setting

Purpose and scope.

Acknowledgments

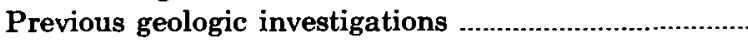

Geomorphic features

Topographic subdivisions

Principal streams

Drainage pattern

Old land surfaces

Stratigraphy

Pre-Tertiary basement complex

Metamorphic rocks

Granitic rocks

Cretaceous and Tertiary Systems

Unnamed formation

Tertiary System

Eocene Series

Reliz Canyon Formation.

Oligocene(?) Series

Berry Formation

Miocene Series

Vaqueros Formation

Tierra Redonda Formation

Monterey Formation

Nomenclature

Members

Sandholdt Member

Hames Member

Buttle Member

Distribution and thickness

Lithology

Porcelaneous rocks

Mudstone and shale..

Diatomaceous rocks

Chert

Dolomite

Sandstone

Phosphorite

Volcanic rocks

Stratigraphic relations

Fossils

Age and conditions of deposition

Santa Margarita Formation

Pliocene Series

Pancho Rico Formation

Nomenclature

Distribution and thickness

Lithology

Sandstone

Mudstone

Conglomerate
Stratigraphy-Continued

Tertiary System-Continued

Pliocene Series-Continued

Pancho Rico Formation-Continued

Stratigraphic relations ............................... 51

Fossils ..................................................... 51

Age and conditions of deposition.............. 54

Tertiary and Quaternary (?) Systems............................. 54

Pliocene and Pleistocene(?) Series........................... 54

Paso Robles Formation .................................... $\quad 54$

Quaternary System ............................................... 58

Pleistocene and Holocene Series............................. $\quad 58$

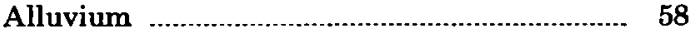

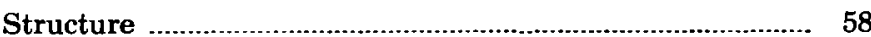

General features ......................................................... 58

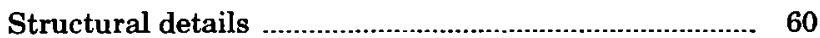

A rea southwest of Jolon-Rinconada fault zone..... 60

Jolon-Rinconada fault zone ................................... 60

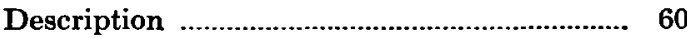

Bee Rock fault zone......................................... 61

Displacement ................................................. 65

Area northeast of Jolon-Rinconada fault zone...... 67

Configuration of the basement complex......... 67

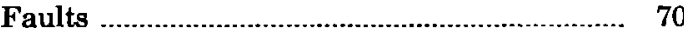

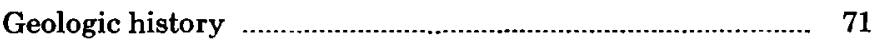

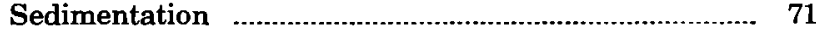

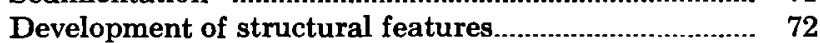

Structural interpretation of topography ....................... 73

Summary of geologic history ……............................... $\quad 75$

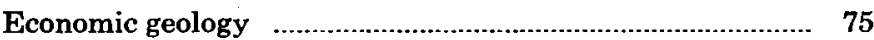

Petroleum 75

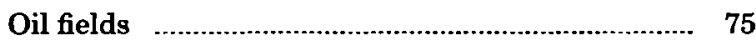

San Ardo oil field ............. $\quad 75$

Paris Valley oil field........................................... $\quad 77$

King City oil field.

Monroe Swell oil field ......................................... 78

Lynch Canyon oil field...................................... 78

McCool Ranch oil field................................... 78

Bituminous rock ................................................ 78

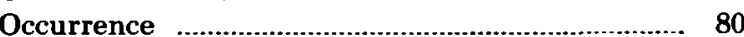

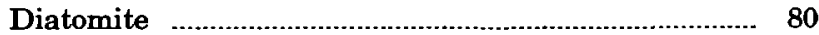

Gold

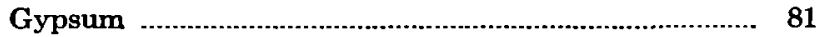

Lime and limestone ....................................................... 81

Mineral water ................................................................ 81

Phosphate

Sand and gravel ....................................................... 82

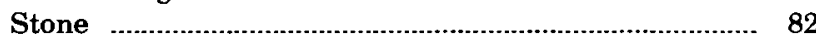

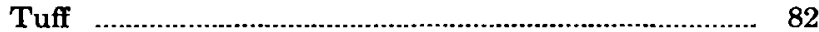

Collection-locality descriptions …………........................... 82

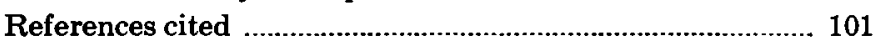

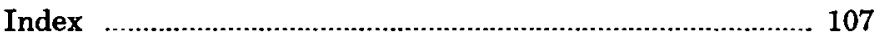




\section{ILLUSTRATIONS}

[Plates are in pocket]

Plate 1. Geologic map of the southern Salinas Valley area, California.

2. Structure sections of the southern Salinas Valley area, California.

3. Maps showing structure contours on the surface of the basement complex and complete Bouguer gravity, southern Salinas Valley area, California.

4. Economic geology map of the southern Salinas Valley area, California.

Figure 1. Index map showing location of the southern Salinas Valley area

2. Index map showing quadrangles in the southern Salinas Valley area

3. Map showing topographic subdivisions and drainage pattern in the southern Salinas Valley area

4. Diagram showing longitudinal profiles of the Salinas River and principal tributaries in the southern Salinas Valley area.

5. Photograph showing terraces near the mouth of Reliz Canyon

6. Photograph showing terraces above the Nacimiento River

7. Map showing approximate reconstruction of some old land surfaces in upland tracks of the southern Salinas Valley area.

8. Photograph showing even-crested ridges near the mouth of Pancho Rico Creek

9. Map showing approximate distribution of units that lie on the basement complex northeast of the Jolon-Rinconada fault zone

10. Schematic diagram showing generalized relations of rock-stratigraphic units in the southern Salinas Valley area

11. Diagram of stratigraphic nomenclature in the southern Salinas Valley area

12. Map showing approximate distribution of the unnamed formation of Cretaceous and Paleocene age and the Reliz Canyon Formation in the southern Salinas Valley area

13-15. Photographs:

13. Hackly mudstone in the unnamed formation of Cretaceous and Paleocene age.

14. Massive sandstone in the type Reliz Canyon Formation

15. Hackly mudstone in the type Reliz Canyon Formation

16. Map showing approximate distribution of the Berry Formation in the southern Salinas Valley area.......... 23

17. Photograph showing cross-stratified conglomeratic sandstone in the Berry Formation............................... 24

18. Map showing approximate distribution of the Vaqueros Formation in the southern Salinas Valley area....... 26

19-21. Photographs:

19. Massive cavernous sandstone in the Vaqueros Formation ................................................................

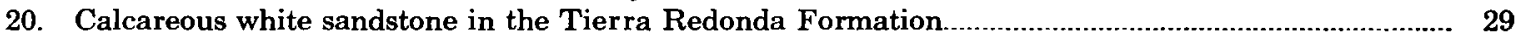

21. Boulder of granitic rock from the Tierra Redonda Formation

22. Map showing approximate distribution of the Tierra Redonda Formation and the Sandholdt Member of

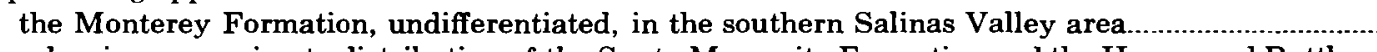

23. Map showing approximate distribution of the Santa Margarita Formation and the Hames and Buttle 24-29. Photographs: Members of the Monterey Formation, undifferentiated, in the southern Salinas Valley area..

24. Shaly calcareous mudstone in the Sandholdt Member of the Monterey Formation..

25. Calcareous shale in the Sandholdt Member of the Monterey Formation.

26. Well-bedded porcelaneous rock in the Hames Member of the Monterey Formation

27. Massive porcelaneous rock in the Hames Member of the Monterey Formation...

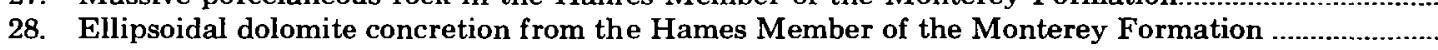

29. Internal features of dolomite concretions in the Hames Member of the Monterey Formation..

30. Maps showing general distribution of foraminif eral faunas of the Miocene Saucesian, Relizian, and

Luisian Stages of Kleinpell (1938) in the southern Salinas Valley area..

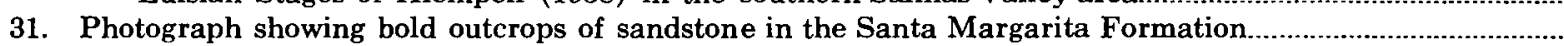

32. Map showing approximate distribution of the Pancho Rico Formation in the southern Salinas Valley area.

33-36. Photographs:

33. Massive very fine grained sandstone in the Pancho Rico Formation................................................. 50

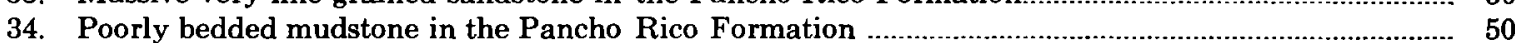

35. Cross-stratified pebble conglomerate in the Paso Robles Formation................................................. 56

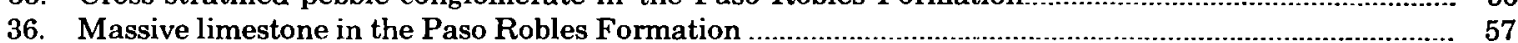

37. Map showing relation of the southern Salinas Valley area to the Salinian block...................................... 59

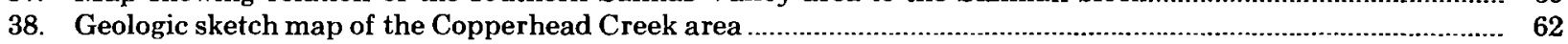

39. Geologic sketch map of the lower San Antonio River area ................................................................................... 64

40. Photograph showing deformed beds in the Sandholdt Member of the Monterey Formation above the

Bee Rock fault zone......

41. Geologic sketch map of the Bee Rock area.. 
Figures 42-45. Photographs:

42. Thrust fault in the Sandholdt Member of the Monterey Formation

43. Bituminous sandstone at the base of the Paso Robles Formation.

44. Lenticular bituminous sandstone body near the top of the Monterey Formation

45. Massive gypsum interbedded in the Paso Robles Formation

46. Map showing surveyed land boundaries in the southern Salinas Valley area.

81

\section{TABLES}

TABLE

1. Summary of geologic history

Page

2. Oil production from the southern Salinas Valley area, 1947-69

3. Gas production from the southern Salinas Valley area, 1948-69 



\title{
GEOLOGY OF THE SOUTHERN SALINAS VALLEY AREA, CALIFORNIA
}

\author{
By David L. Durham
}

\begin{abstract}
The southern Salinas Valley area lies in parts of Monterey, San Luis Obispo, and San Benito Counties, Calif. It is in the Coast Ranges - a geomorphic province between the Great Valley and the Pacific Ocean - and contains upland tracts of hills and mountains separated by lowland areas of moderate relief. The mapped area is entirely within the drainage basin of the Salinas River; the northwesterly course of the river dominates the drainage pattern, which is modified by local structural features. Even-crested hills and ridges are apparently remnants of old land surfaces that have been dissected by modern streams.

Sedimentary rocks in the mapped area that range in age from Cretaceous to Pliocene and Pleistocene(?) are assigned to 11 rock-stratigraphic units. Cenozoic strata lie on a preTertiary basement complex composed of granitic and associated metamorphic rocks.

The oldest strata in the area constitute an unnamed formation of Cretaceous and Paleocene age that has been identified in the mapped area only southwest of the Jolon-Rinconada fault zone. The thickness of the formation is unknown because the base of the unit is concealed and wells have failed to reach the rocks beneath. The formation contains conglomerate, sandstone, siltstone, and mudstone. Fossils are abundant at a few localities; they indicate a Late Cretaceous and Paleocene age and demonstrate the marine origin of at least part of the formation.

The stratigraphically lowest beds in the northwestern part of the mapped area constitute the Reliz Canyon Formation. The formation in Reliz Canyon is nearly 2,000 feet thick. The unit is chiefly sandstone; mudstone forms a local member in the lower part, and sandstone near the base is conglomeratic locally. Foraminifers in mudstone in the lower part of the formation indicate an Eocene age and establish that at least part of the unit is marine.

The Berry Formation overlies the Reliz Canyon Formation in the conformable stratigraphic succession exposed in the northwestern part of the area. The Berry generally is 600 $1,500 \mathrm{ft}$ thick, and the unit is chiefly conglomerate and conglomeratic sandstone. The Berry lacks fossils but the stratigraphic position of the Berry indicates that the unit is probably Oligocene. The formation appears to be nonmarine.

The Vaqueros Formation is the oldest widespread sedimentary-rock unit in the mapped area. The Vaqueros generally is $800-2,000 \mathrm{ft}$ thick; the unit is chiefly and characteristically sandstone. The Vaqueros conformably overlies and intertongues with the Berry Formation in the northwestern part of the mapped area, and unconformably overlies the unnamed formation of Cretaceous and Paleocene age between the San

Antonio and Nacimiento Rivers. Fossils and the stratigraphic position of the Vaqueros indicate that the unit is early Miocene; fossils demonstrate the marine origin of most of the formation.

The Tierra Redonda Formation contains sandy beds that are stratigraphically equivalent to finer grained rocks in the Sandholdt Member of the Monterey Formation. The Tierra Redonda is thickest at the type area near Tierra Redonda Mountain, where it is about $1,650 \mathrm{ft}$ thick. The formation is mainly and characteristically sandstone. Where exposed, it conformably overlies the Vaqueros Formation north of the Nacimiento River, unconformably overlies the unnamed formation south of the Nacimiento River, and unconformably overlies basement complex near the Sierra de Salinas and La Panza Range. Fossils and the stratigraphic position of the formation indicate that the unit is Miocene; fossils demonstrate that the formation is at least partly marine.

The Monterey Formation in the mapped area has three members: the Sandholdt, the Hames, and the Buttle. The Sandholdt is mainly calcareous mudstone and shale, which together with associated chert, porcelanite, sandstone, and dolomite make up the lower part of the formation. The Hames is chiefly siliceous mudstone, porcelaneous rocks, chert, and associated dolomite that form the upper part of the formation. The Buttle consists of diatomaceous rocks that occur locally near the top of the formation. The thickness of the Monterey varies considerably from place to place; it is as great as 8,000$10,000 \mathrm{ft}$ in the Reliz Canyon and Hames Valley quadrangles. The Sandholdt Member conformably overlies the Vaqueros Formation where both units are exposed between the Arroyo Seco and Nacimiento River, and conformably overlies and intertongues with the Tierra Redonda Formation north of the Arroyo Seco and south of the San Antonio and Estrella Rivers. The Hames Member conformably overlies the Sandholdt where both members occur, and the Buttle conformably overlies and locally intertongues with, or grades laterally into, the Hames. Both the stratigraphic position and the fossils of the Monterey establish a Miocene age for the unit; the abundance of marine fossils throughout the Monterey demonstrates the marine origin of the formation.

The Santa Margarita Formation contains sandy beds that are stratigraphically equivalent to finer grained rocks in the Hames Member of the Monterey Formation. The lenticularity and intertonguing of the Santa Margarita make thickness estimates for the formation uncertain, but the exposed thickness of the unit generally is at least $500 \mathrm{ft}$. The formation is chiefly and characteristically sandstone; it conformably overlies and intertongues with the Hames Member of the Monterey For-
\end{abstract}


mation. Fossils and the stratigraphic position of the Santa Margarita indicate that the unit is late Miocene; fossils demonstrate the shallow-water marine origin of most of the formation.

The Pancho Rico Formation consists of marine beds that conformably overlie the Monterey Formation at most places in the northern part of the mapped area, and unconformably overlie the basement complex where the Monterey is absent in that part of the area. The formation is thickest near the mouth of the Arroyo Seco, where it is about $1,250 \mathrm{ft}$ thick, and east of Reliz Canyon, where it may be greater than $1,000 \mathrm{ft}$ thick. The Pancho Rico is chiefly and characteristically sandstone, but it also contains conglomerate, mudstone, diatomite, and porcelanite. Fossils in the unit indicate a Pliocene age and provide ample evidence of the marine origin of most of the formation; they commonly suggest a shallow-water nearshore marine environment.

The term "Paso Robles Formation" applies to strata that accumulated after withdrawal of the Tertiary sea and before deposition of sediments classed as alluvium. The distribution of the Paso Robles suggests that at one time the formation covered most, if not all, of the area. The thickness of the formation varies considerably, largely because the upper part of the unit has been lost by erosion. The Paso Robles is mainly sandstone and conglomerate, with some mudstone and limestone, and minor amounts of gypsum and woody lignite. Although there is little direct fossil evidence concerning the age of the Paso Robles, the stratigraphic position of the unit between the Pancho Rico Formation and alluvium indicates Pliocene and Pleistocene (?) age. Crude bedding, poor sorting, cross-stratification, and channeling in parts of the formation suggest that the unit is nonmarine and largely fluviatile in origin. Sediments younger than the Paso Robles are classed as alluvium and include: (a) old alluvium associated with old land surfaces in the hills (b) old alluvium in valleys and lowland areas (c) modern alluvium in stream beds (d) debris-flow material and (e) dune sand.

The southern Salinas Valley area lies mainly on the Salinian block, a structural element of the Coast Ranges that is characterized by a basement of granitic and high-grade metamorphic rocks. The basement rocks of the Salinian block contrast markedly with rocks of the Franciscan Formation in adjacent regions. Outcrops of the unnamed formation of Cretaceous and Paleocene age mark structural highs southwest of the Jolon-Rinconada fault zone-in the part of the area that seems to lie beyond the southwest border of the Salinian block. The fault zone itself extends for more than 50 miles through the area, from the San Antonio River valley to the western margin of the La Panza Range. At most places the zone is flanked on the southwest side by easily deformed shaly rocks of the Monterey Formation that are thrust southwestward over less easily deformed sandy rocks of older units. The Monterey beds are severely deformed at many places, but the underlying sandy rocks generally are no more than moderately tilted. The contrast between rocks on the east and west sides of the Jolon-Rinconada fault zone indicates two distinctly different episodes of displacement: (a) a Late Cretaceous or early Tertiary episode of crustal shortening perpendicular to the continental margin, and (b) a late Tertiary or early Quaternary episode of right-lateral strike-slip displacement more nearly parallel to the continental margin.

The surface of the basement complex northeast of the Jolon-Rinconada fault zone has high areas - the Gabilan, Junipero Serra, Lockwood, and La Panza highs - separated by a series of interconnected troughlike depressions, all appar- ently formed by warping and faulting of the basement rocks. Faults are uncommon over the Gabilan high but are common at most other places in the mapped area where rocks older than the Paso Robles Formation crop out. Relief features on the basement-complex surface are of two types: Those formed during or before early Tertiary time, and those formed during or after latest Tertiary time, when most of the structural features in the sedimentary-rock cover also developed. Some topographic features in the area are closely related to the structure of underlying rocks.

Rocks and sediments in the mapped area have yielded a variety of commercially valuable commodities, including oil and gas, bituminous rock, diatomite, gold, gypsum, mineral water, sand and gravel, stone, and tuff. Surface indications of oil attracted pioneer oil prospectors to the area near the end of the 19th century, but the first commercial production began 50 years later; oil and gas produced in the area are mainly from the San Ardo oil field. Bituminous rock is conspicuous at several localities and was mined for paving material. Diatomite produced commercially came from the Buttle Member of the Monterey Formation; gypsum produced commercially came from the Paso Robles Formation. Placer gold was recovered from alluvium in the San Antonio River, Nacimiento River, and San Marcos Creek. Lime was produced on a small scale during the late 19th century, mainly from deposits of fossil shells; coarsely crystalline limestone in the basement complex just south of the Arroyo Seco is undeveloped. Hot and cold mineral-water springs and wells were the basis for development of popular spas at several places late in the 19th century. Phosphate in the Monterey and Pancho Rico Formations has been prospected but not produced commercially. Sand and gravel are produced mainly for short-term or intermittent local needs. Rock from the Monterey Formation is used for riprap and for ornamental building stone. Miocene tuff was mined for use as an abrasive or polish.

\section{INTRODUCTION}

\section{LOCATION AND GEOLOGIC SETTING}

The southern Salinas Valley area lies in parts of Monterey, San Luis Obispo, and San Benito Counties, Calif. (fig. 1), and includes part or all of 16 15-minute, or $417 \frac{1}{2}$-minute quadrangles (fig. 2). It is in the southern Coast Ranges, where a thick blanket of Upper Cretaceous and Cenozoic clastic rocks overlies and partly conceals two distinctly different kinds of basement terrane (fig. 37) - one characterized by an assemblage of Jurassic and Cretaceous eugeosynclinal rocks commonly referred to as the Franciscan Formation, and the second composed of Cretaceous granitic rocks and associated older metamorphic rocks. The two terranes are mutually exclusive in that they are everywhere separated by faults. The rocks of the Coast Ranges seem to record two principal modes of deformation. One involves crustal shortening nearly perpendicular to the continental margin; the other is characterized by right-lateral shear more nearly parallel to the margin. The first mode could explain the enigmatic juxtaposition of Franciscan and granitic 


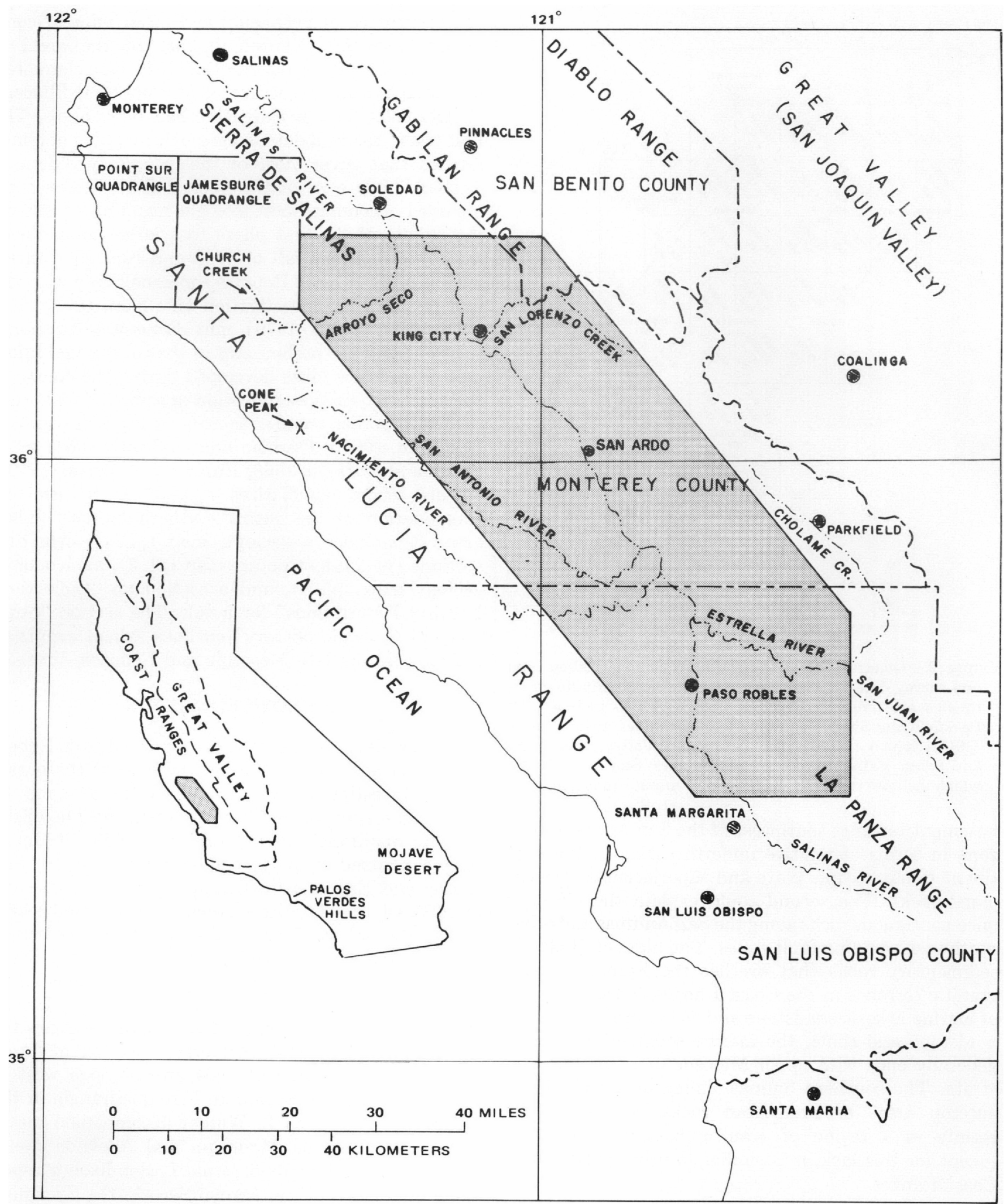

FIGURE 1.-Location of the southern Salinas Valley area (shaded). 


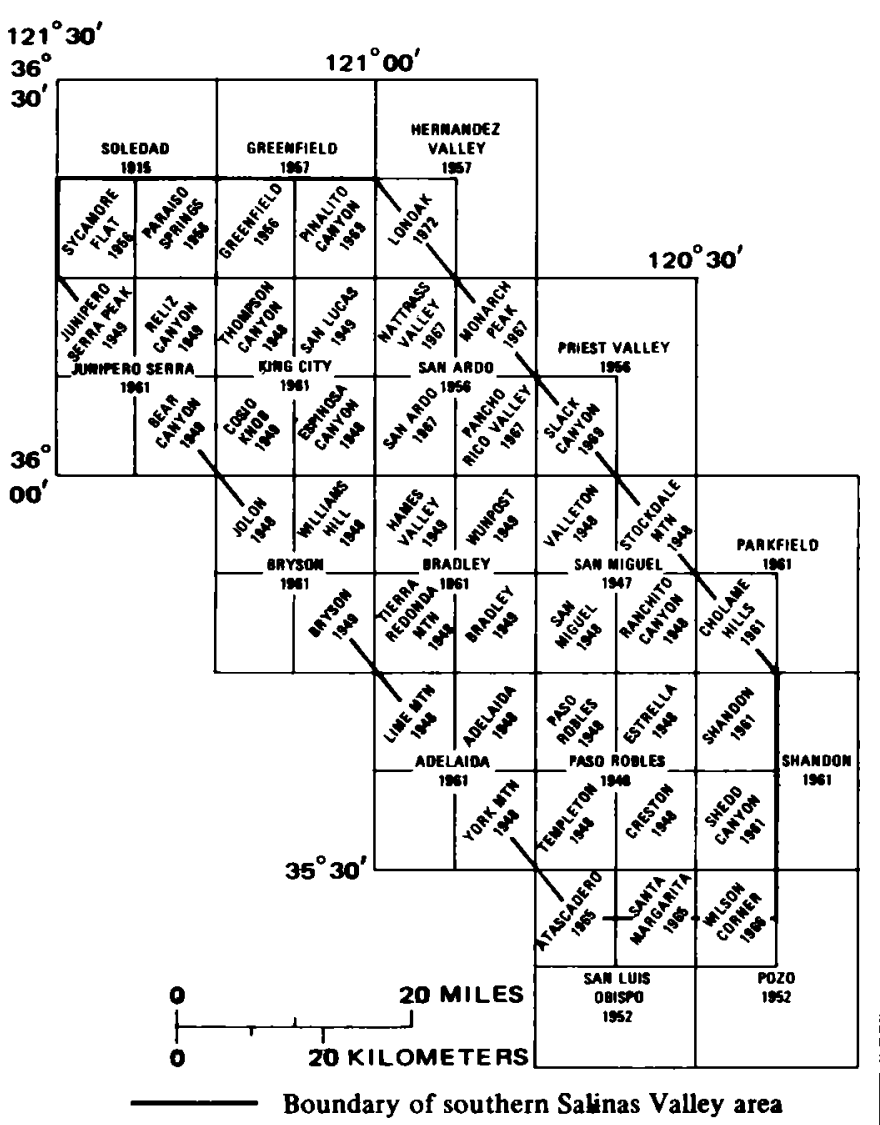

FiguRE 2.-Quadrangles in the southern Salinas Valley area and survey date for each. The following old 30-minute quadrangles are omitted: Cholame (1915), which includes the Parkfield and Shandon 15-minute quadrangles; Priest Valley (1915), which includes the Hernandez Valley, San Ardo, and Priest Valley 15-minute quadrangles; San Luis (1903), which includes the San Luis Obispo 15-minute quadrangle.

basement terranes southwest of the San Andreas fault zone in terms of relative underthrusting of the continent by an oceanic plate and superjacent eugeosynclinal rocks. The second could explain the offset of once-contiguous rocks along the San Andreas and other northwest-trending fault zones. The blanket of clastic sedimentary rocks that overlies the Franciscan and granitic terranes in the Coast Ranges consists mainly of marine arkosic sandstone and richly organic marine mudstone and shale; the marine sedimentary record generally ends with upper Miocene or lower Pliocene strata. The southern Salinas Valley area lacks large outcrop areas of Franciscan rocks because it lies mainly in a region of granitic basement complex; except for this lack, it is similar to other parts of the Coast Ranges.

\section{PURPOSE AND SCOPE}

U.S. Geological Survey investigation of the southern Salinas Valley was concerned mainly with relating the occurrence of petroleum and other mineral commodities to the Cenozoic history of the area; it emphasized study of distribution, lithologic character, stratigraphy, and structure of Miocene and Pliocene marine beds. The investigation had two phases. The first phase involved detailed geologic mapping of quadrangles that cover most of the complexly deformed Tertiary beds west of the Salinas River; the second included reconnaissance geologic mapping to extend the results of the first phase to a larger area. Fieldwork began in the fall of 1958 and continued intermittently until 1969. Reports concerned only with the first phase of the investigation (Durham, 1963, 1964, 1965a, 1966, 1968a, 1970) omit discussion of regional relations and are preliminary in that additional information and new ideas developed during the course of the study required modification of some details; other reports describe broader aspects of the investigation (Durham, 1965b; Durham and Addicott, 1964, 1965; Smith and Durham, 1968; Burch and Durham, 1970).

This report summarizes results of the geologic investigation of the entire southern Salinas Valley area. It includes a geologic map (pl. 1), structure sections (pl. 2), a structure map (pl. 3), an economic geology map (pl. 4), and a section on "CollectionLocality Descriptions" for fossils. The section "Summary of Geologic History" outlines salient events in the area during late Mesozoic and Cenozoic time.

\section{ACKNOWLEDGMENTS}

Eight assistants participated in the fieldwork. Robert $P$. Hunter accompanied me in the field at the outset of the investigation in the fall of 1958. John C. Robinson mapped near Pine Canyon in the Thompson Canyon quadrangle in the spring of 1959. Phillip J. Pattee mapped in parts of the Reliz Canyon, San Lucas, and Espinosa Canyon quadrangles in the fall of 1959. Charles L. Rice mapped and collected fossils east of the Salinas River in the San Ardo quadrangle in the spring of 1960. David C. Wiese worked south of the San Antonio River in the Jolon and Williams Hill quadrangles in the spring of 1962 and in the Hames Valley and Tierra Redonda Mountain quadrangles the following fall. Robert J. McLaughlin worked at Camp Roberts in the spring of 1964 and mapped west of Piney Creek in the Sycamore Flat quadrangle in the fall of 1967. Thomas $L$. Winder accompanied me in the Tierra Redonda Mountain and Adelaida quadrangles in the fall of 1965 . Roald L. Bendixon mapped along and south of the Arroyo Seco in the Sycamore Flat, Paraiso Springs, and Junipero Serra Peak quadrangles in the fall of 1966 . I am greatly indebted to them all for their labor, forbearance, and good cheer. 
Warren O. Addicott identified most of the larger invertebrate fossils and provided valuable information on their age and ecologic significance; he also collected fossils in the field on several occasions. Ellen J. Moore identified larger invertebrate fossils collected before 1962; J. Wyatt Durham identified fossil echinoids from several localities. Patsy B. Smith identified foraminifers from the Monterey and Pancho Rico Formations and provided significant data on the age and ecologic interpretation of the fossils. Merle C. Israelsky identified Eocene and Paleocene foraminifers from the Reliz Canyon and Jolon quadrangles. Richard L. Pierce collected and identified Eocene and Pliocene foraminifers from Reliz Canyon and identified Cretaceous foraminifers from the Bryson quadrangle.

I profited considerably from discussion of the geology of the southern Salinas Valley area with Thomas W. Dibblee, Jr., Edward A. Gribi, Jr., Walter S. Harris, Earl W. Hart, and Richard R. Thorup. Well data provided by Edward A. Gribi, Jr., Walter S. Harris, H. H. Haun, Richard R. Thorup, and Arthur R. Weller was valuable. K. J. Murata kindly provided information on isotope ratios of some carbonate rocks and on interpretation of the data.

\section{PREVIOUS GEOLOGIC INVESTIGATIONS}

Geologic studies in the southern Salinas Valley area began in the mid-19th century, mainly in connection with federal surveys for railroad routes. Other geologic work done before the end of the century was sponsored chiefly by the State of California and generally was related to mineral resources. University geologists began more general geologic inquiries near the end of the century, and U.S. Geological Survey studies began about 1900 . Investigations of stratigraphy and paleontology increased markedly after 1900 , and studies of foraminifers began in earnest about 1925. A conspicuous increase in publications concerned with petroleum resources followed discovery of the San Ardo oil field in 1947. The number of papers on structural geology that were published after 1960 reflects increased interest in Coast Range tectonics and the San Andreas fault.

\section{GEOMORPHIC FEATURES}

The southern Salinas Valley area is in the Coast Ranges, a geomorphic province (Jenkins, 1943, p. 8687) between the Great Valley and the Pacific Ocean (fig. 1). The province is characterized by ridges and valleys that trend $N$. $30^{\circ}-40^{\circ} \mathrm{W}$. and dominate the gross topography of the mapped area. The relief in the area is greater than $5,000 \mathrm{ft}$; the lowest point is the bed of the Salinas River at $200 \mathrm{ft}$ in the Greenfield quadrangle, and the highest is the top of Pinyon Peak at $5,264 \mathrm{ft}$ in the Junipero Serra Peak quadrangle. Many topographic features in the area are closely related to the structure and structural history of the underlying rocks; these relations are discussed in the section "Structural Interpretation of Topography."

\section{TOPOGRAPHIC SUBDIVISIONS}

The mapped area contains upland tracts of hills and mountains separated by lowland areas of moderate relief (fig. 3). Landforms in the area include: (a) steep-mountain terrain, as in the Junipero Serra Peak quadrangle, (b) rounded hills, as between the Salinas and San Antonio Rivers, (c) deeply dissected tableland, as east of the Salinas River, (d) flat areas along major streams, as near King City, and (e) dissected old land surfaces, as south of the Estrella River. Fans composed of debris from the upland tracts encroach upon lowland areas at many places, most notably near the mouth of the Arroyo Seco and north of Lockwood.

\section{PRINCIPAL STREAMS}

The mapped area is entirely within the drainage basin of the Salinas River. The Salinas descends from an elevation of about $900 \mathrm{ft}$ in the Santa Margarita quadrangle to about $200 \mathrm{ft}$ in the Greenfield quadrangle for an average gradient of nearly $8 \mathrm{ft}$ per mile (fig. 4). The river enters the mapped area through a narrow gorge that is clearly the result of superimposition of an earlier stream course into the basement complex of the La Panza Range (Fairbanks, 1940a, p. 13). It flows northwestward from the gorge to the Estrella River through a lowland area of moderate relief on a flood plain a quarter to a half mile wide; the flood plain lies between hills that are generally $100-300 \mathrm{ft}$ above the river. The Salinas, from its junction with the Estrella River to the junction with the San Antonio River, flows on a flood plain that generally is no wider than a quarter of a mile. Nearby hills to the east that are 700-1,000 ft above the flood plain have blunt steep faces and numerous slides; both features suggest erosion at the base of the hills by the Salinas River. North of its junction with the San Antonio River, the Salinas flows through a narrow canyon one-third to one-half mile wide; north of the narrow canyon, the river has a flood plain that generally is three-fourths to 1 mile wide in a valley 2-5 miles wide. Opposite the mouth of San Lorenzo Creek, the Salinas River is on the west side of the valley; farther north opposite the mouth of the Arroyo Seco, it is on the east side. These positions suggest that the fans of the tributaries influence the location of the Salinas.

The Arroyo Seco is the northernmost major tribu- 


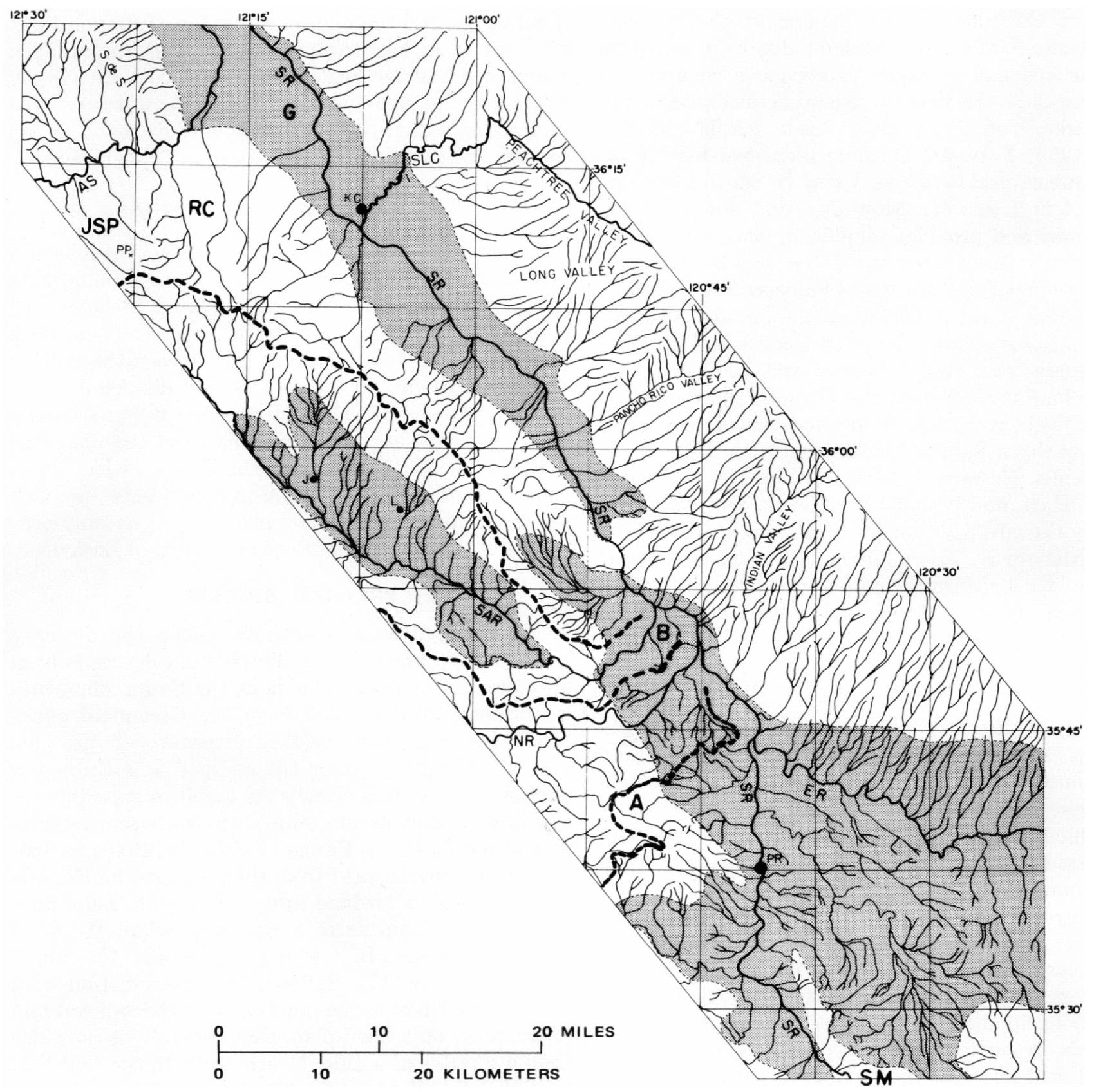

Figure 3.-Topographic subdivisions and drainage pattern in the southern Salinas Valley area. Lowland areas (shaded) generally have less than $400 \mathrm{ft}$ of relief within circles 1 mile in diameter; upland tracts (unshaded) have greater relief. Heavy dashed lines indicate major drainage divides. (Quadrangles identified in fig. 2.) Abbreviations: A, Adelaida quadrangle; AS, Arroyo Seco; B, Bradley quadrangle; ER,
Estrella River; G, Greenfield quadrangle; J, Jolon; JSP, Junipero Serra Peak quadrangle; KC, King City; L, Lockwood; NR, Nacimiento River; PP, Pinyon Peak; PR, Paso

Robles; RC, Reliz Canyon quadrangle; SAR, San Antonio River; S de S, Sierra de Salinas; SLC, San Lorenzo Creek; SM, Santa Margarita quadrangle; SR, Salinas River.

tary to the Salinas River in the mapped area and the only stream that breaches the upland tract in the northwestern part of the area (fig. 3). It heads in the Santa Lucia Range and flows eastward through a deep narrow canyon at the south end of the Sierra de Salinas to meet the Salinas River just north of the mapped area (fig. 1). Hills within half a mile of the Arroyo Seco are as high as $1,200 \mathrm{ft}$ above it in the Junipero Serra Peak quadrangle and as high as $800 \mathrm{ft}$ above it in the Paraiso Springs quadrangle. Terraces at several levels flank the Arroyo Seco; the most prominent is about $80-100 \mathrm{ft}$ above the stream in the Junipero 


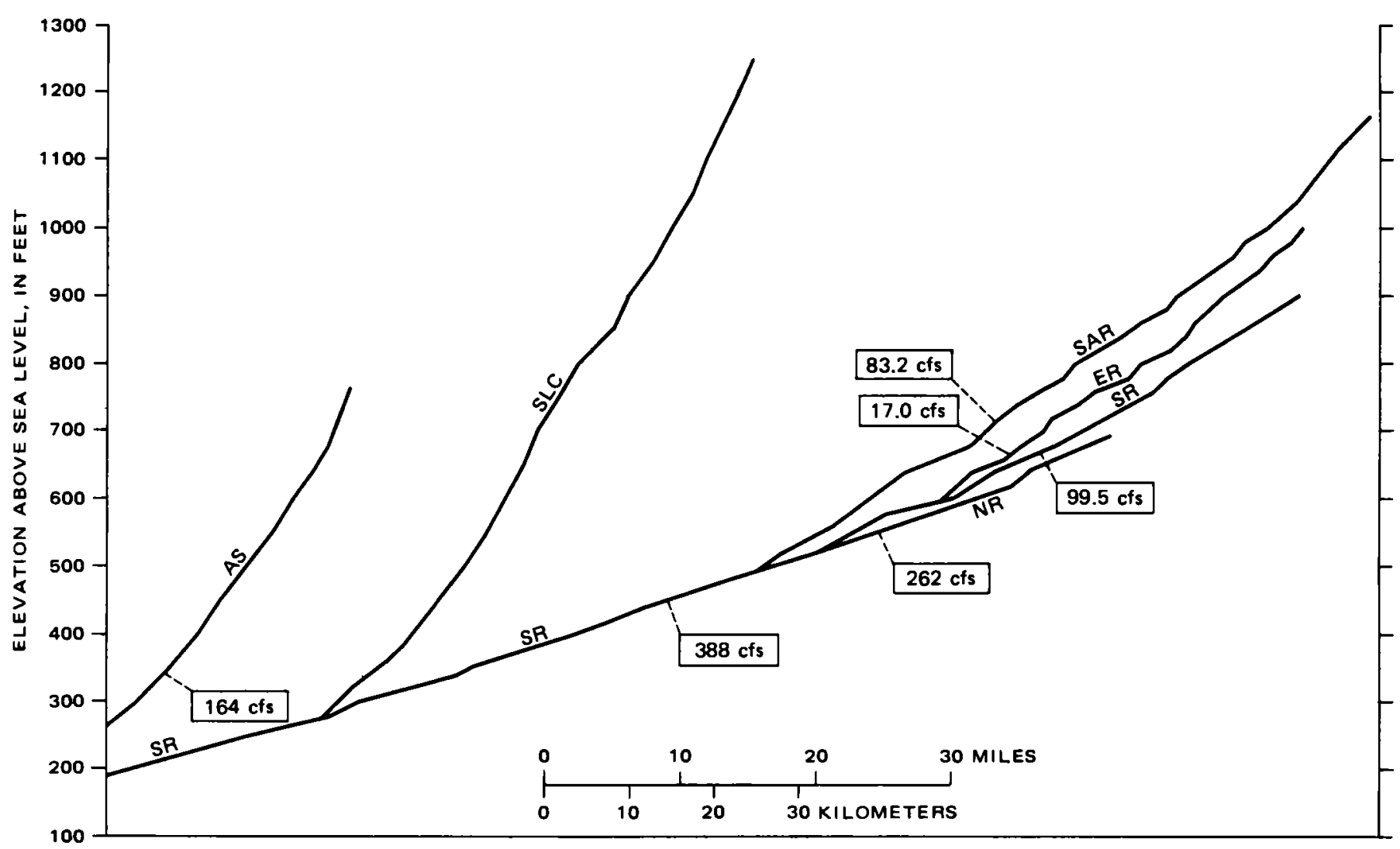

FiguRE 4.-Longitudinal profiles of the Salinas River and principal tributaries in the southern Salinas Valley area. Numbers in boxes are average discharge figures in cubic feet per second (cfs) measured at stream-gaging stations indicated by dashed lines (U.S. Geol. Survey, 1964, p. 205-213). Abbreviations: AS, Arroyo Seco; ER, Estrella River; NR, Nacimiento River; SAR, San Antonio River; SLC, San Lorenzo Creek; SR, Salinas River.

Serra Peak quadrangle and $40-60 \mathrm{ft}$ above the stream in the Paraiso Springs quadrangle (fig. 5). The terraces are obviously remnants of an old valley floor on which the ancient Arroyo Seco flowed in looping meanders; the modern Arroyo Seco is incised below the old valley floor and has a winding course inherited from the ancient stream. Two lakes at the west edge of the mapped area, about $100 \mathrm{ft}$ above the modern stream, occupy a cutoff meander of the ancient Arroyo Seco. Patches of gravel on ridges high above the Arroyo Seco record early stages in the history of the stream; some gravel deposits in the Paraiso Springs quadrangle that are within $1 \frac{1}{4}$ mile of the stream are as much as 1,500 $\mathrm{ft}$ above it.

San Lorenzo Creek flows northwestward along Peachtree Valley, then westward through a narrow canyon to reach the Salinas River at King City (fig. 3). The course of the stream along Peachtree Valley seems structurally controlled because it parallels the nearby San Andreas fault zone (fig. 37). The narrow canyon west of Peachtree Valley, cut mainly in basement complex, follows a meandering course that suggests super- imposition of an ancient stream that flowed on a low gradient across the soft sedimentary rocks that cover the basement complex. Streams between Peachtree Valley and the Salinas River are beheaded by San Lorenzo Creek. Long Valley, for example, extends eastward from the Salinas River for about 15 miles and ends abruptly less than half a mile from, but about $350 \mathrm{ft}$ above, San Lorenzo Creek; the valley lacks even an intermittent stream along most of its length (fig. 3) although a large stream obviously formed the feature. The absence of a modern stream in Long Valley suggests that after capture of the upper reaches of the ancient stream, too little drainage area was left to maintain surface runoff in the remaining stream course.

The San Antonio River, which heads outside the mapped area in the Santa Lucia Range, flows southeastward to meet the Salinas River (fig. 1). The valley or canyon of the San Antonio is no wider than a quarter of a mile through most of the Bear Canyon quadrangle, but it is as much as $21 / 2$ miles wide in the Jolon quadrangle. The valley bifurcates farther east in the Williams Hill quadrangle, where the river flows south- 


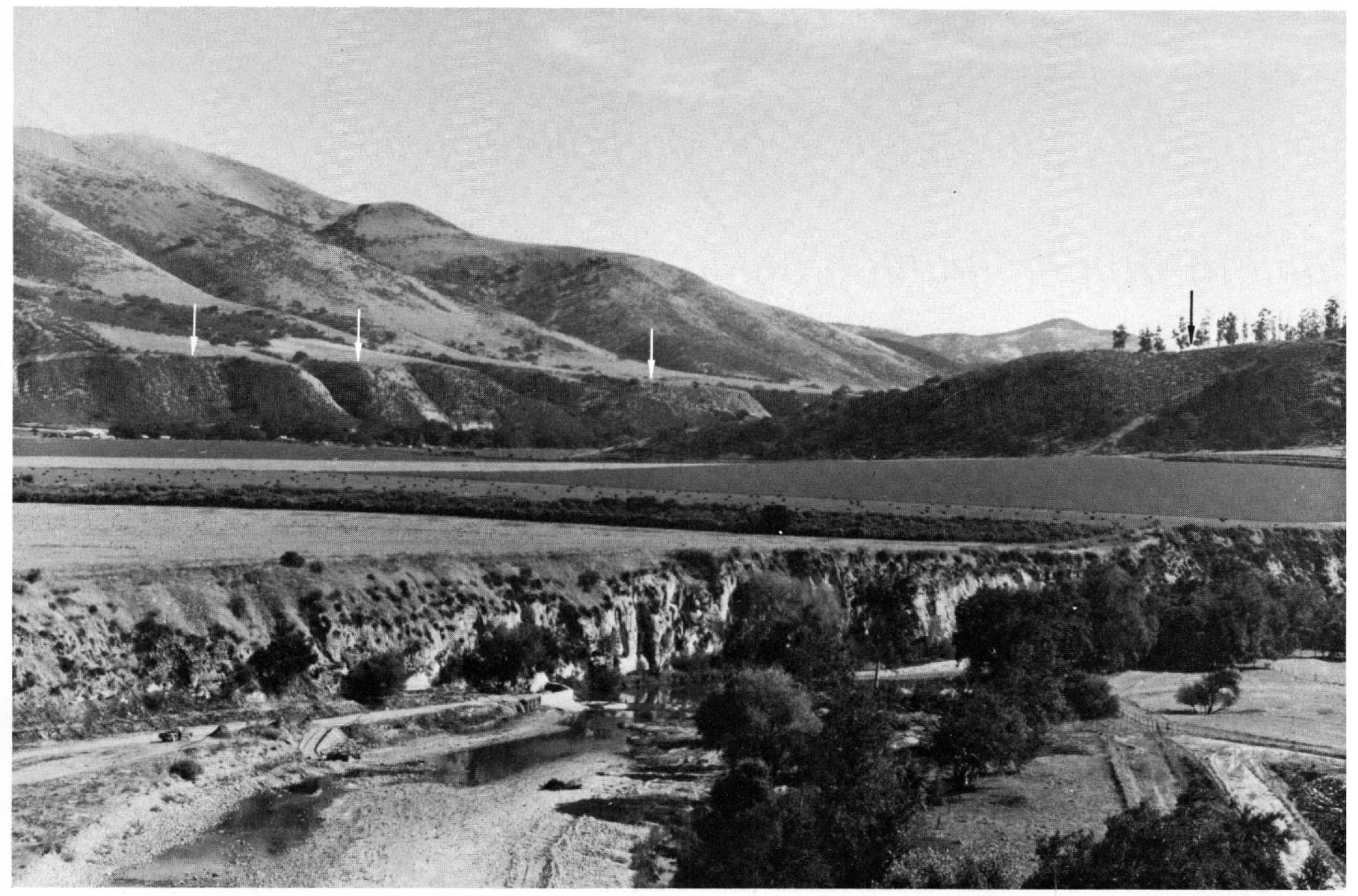

Figure 5.-Terraces near the mouth of Reliz Canyon, Paraiso Springs quadrangle. The Arroyo Seco is incised about $40 \mathrm{ft}$ below the terrace in the foreground. Terraces on both sides of Reliz Canyon (arrows) are about $200 \mathrm{ft}$ higher.

eastward in a narrow canyon a quarter to a half mile wide between hills that are $200-400 \mathrm{ft}$ above the stream, and the main broad valley extends eastward without a trunk stream from Jolon to Lockwood. Most streams that debouch from the hills north of Lockwood fail to cross the broad valley, and therefore, they fail to reach the San Antonio; other streams that head in the valley near Lockwood carry runoff from the Lockwood area to the San Antonio River (fig. 3). In the Tierra Redonda Mountain quadrangle, the San Antonio River flows through a canyon a quarter to a half mile wide (fig. 39) between hills that are 400$1,000 \mathrm{ft}$ above the stream. The river leaves the canyon in the Bradley quadrangle, where it turns northeastward across a lowland area of moderate relief to reach the Salinas River. The San Antonio is flanked along the last 4 miles of its course by rounded or nearly flat hills that are $200-300 \mathrm{ft}$ above the stream.

The Nacimiento River flows nearly parallel to the San Antonio River; in the Tierra Redonda Mountain and Bradley quadrangles, the two streams are only
2-4 miles apart (fig. 3). Like the San Antonio, the Nacimiento heads outside the mapped area in the Santa Lucia Range and flows through a deep canyon before turning northeastward across a lowland area of moderate relief to reach the Salinas River. The winding course of the Nacimiento through the deep canyon suggests superimposition of an ancient meandering stream that flowed on a low gradient across an old land surface well above the modern stream. The Nacimiento is bordered in the canyon by terraces 40-60 (fig. 6) and $140-160 \mathrm{ft}$ above the river. The Nacimiento has a lower gradient and a greater discharge than the Salinas River above their junction (fig. 4); in terms of runoff, the Nacimiento is the principal headward continuation of the lower reaches of the Salinas.

The Estrella River joins the Salinas River from the east and drains most of the southeastern part of the mapped area. The Estrella has great loops and meanders that suggest superimposition of an ancient stream that flowed on a low gradient across an old land surface well above the modern stream. 


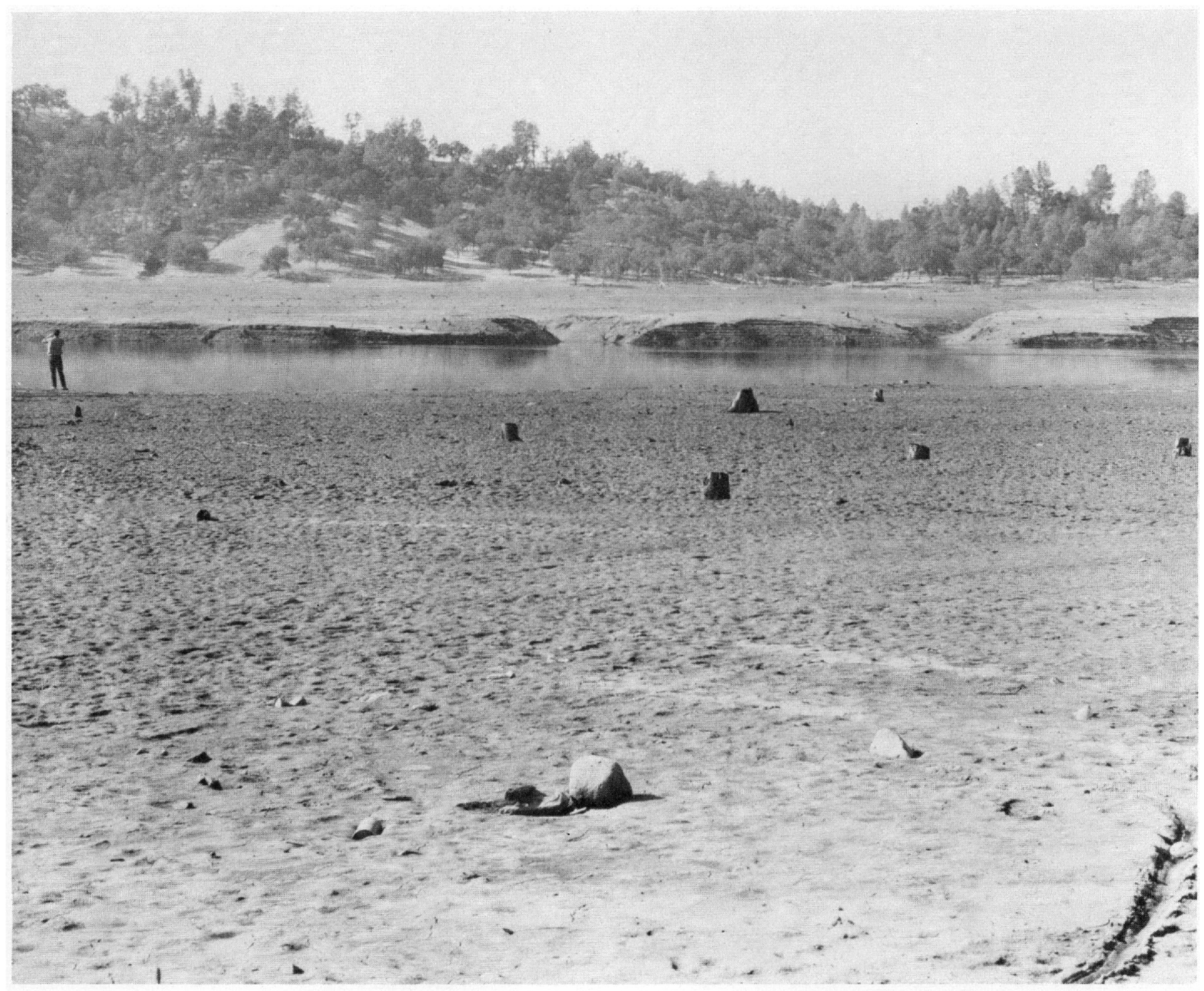

FIGURE 6.-Terraces 40-60 ft above the bed of the Nacimiento River near the north edge of the Lime Mountain quadrangle. The terraces are exposed when the water level behind the Nacimiento Dam is low.

\section{DRAINAGE PATTERN}

The northwesterly course of the Salinas River dominates the mapped-area drainage pattern (fig. 3 ), which is modified by local structural features. Streams east of the Salinas and north of the Estrella River generally flow southwestward, are long and straight, and have few large tributaries. Most major canyons between San Lorenzo Creek and Indian Valley have steeper hillsides and fewer tributaries on the south and southeast sides than they have on the north and northwest sides; this asymmetry is especially noticeable in Long Valley and along Pancho Rico Creek (fig. 8). Streams south of the Estrella and Nacimiento Rivers generally have more bends and branches than streams farther north; streams south of the Nacimiento River flow in a modified radial pattern from a hub in the Adelaida quadrangle. The San Antonio and Nacimiento Rivers are peculiar in that both streams flow southeastward nearly parallel to the Salinas River, but in a direction opposite to the Salinas for most of their length (fig. 1) before turning northeastward to join the Salinas in the Bradley quadrangle. Most streams north of the San Antonio River have long, straight courses and generally branch only in their upper reaches. The stream pattern north of the Arroyo Seco outlines the south end of the Sierra de Salinas.

\section{OLD LAND SURFACES}

Even-crested hills and ridges in the mapped area are apparently remnants of old land surfaces that have 


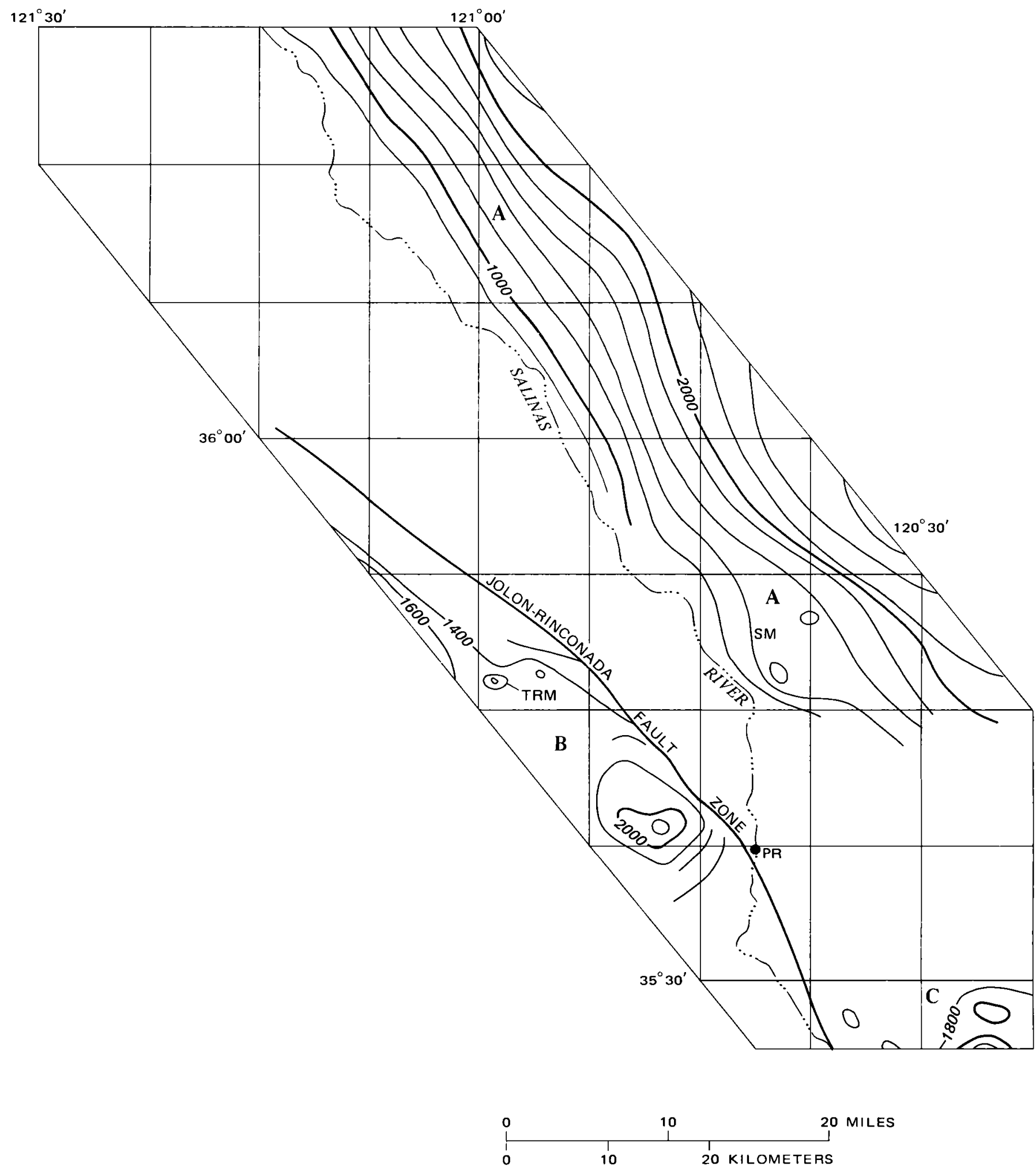

Figure 7.-Approximate reconstruction of some old land surfaces (A, B, C) in upland tracts of the southern Salinas Valley area based on the present elevation of prominences on accordant hill and ridge tops. Contour interval $200 \mathrm{ft}$ (quadrangles identified in fig. 2). Abbreviations: PR, Paso Robles; SM, San Miguel quadrangle; TRM, Tierra Redonda Mountain. 


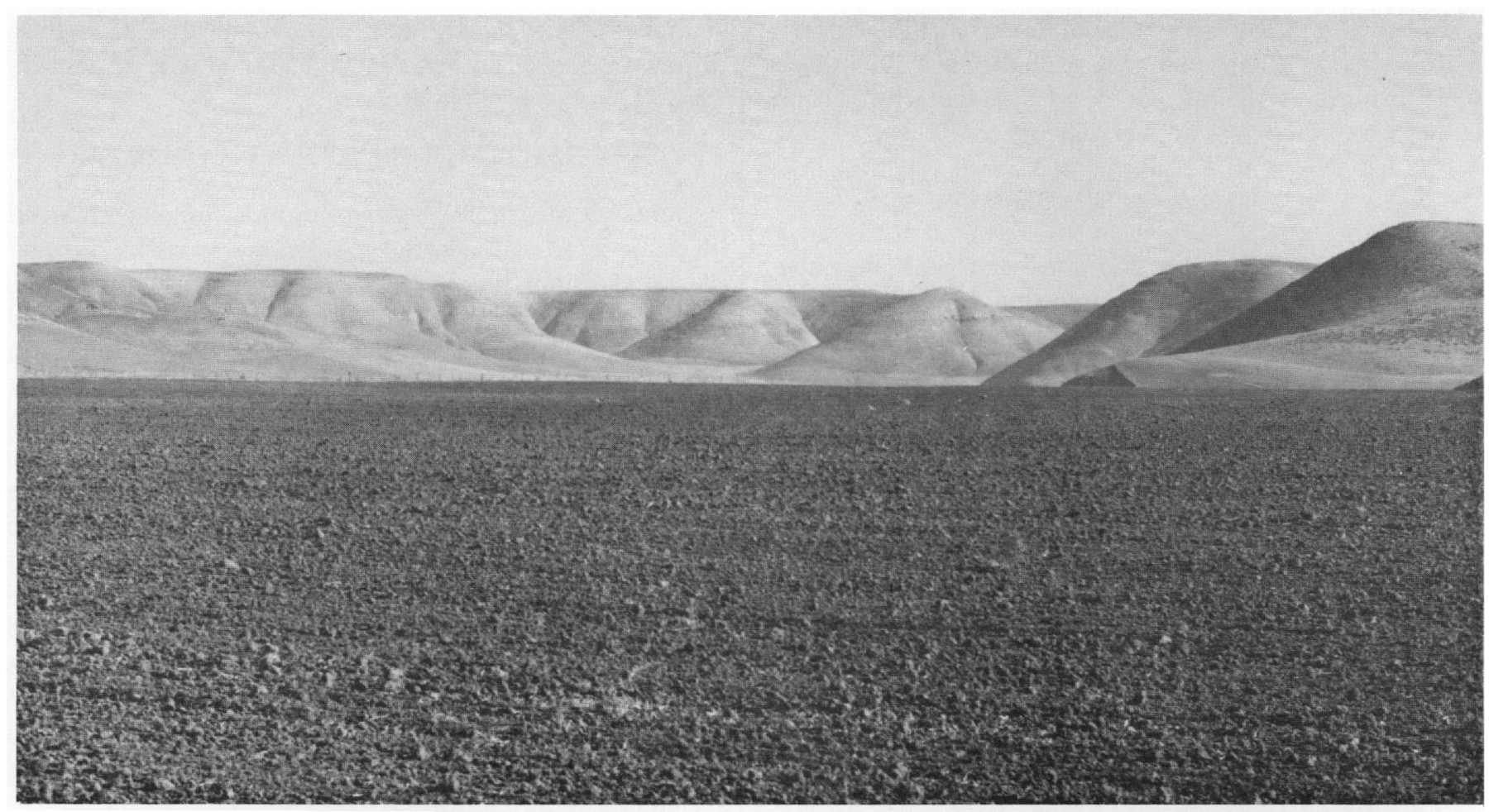

Figure 8.-Even-crested ridges near the mouth of Pancho Rico Creek. Hillsides generally are steeper and tributaries fewer on the south (right) side of the valley than on the north (left) side. The ridgetops are about $600 \mathrm{ft}$ above the valley floor.

been dissected by modern streams. Flat areas that are incongruous with respect to modern streams, and that are being destroyed by the streams, are probably relics of the old surfaces. Most old land surfaces in upland tracts obviously antedate the present drainage system, but old land surfaces in lowland areas seem related to early stages in development of modern streams. Reconstruction of some old land surfaces in upland tracts. (fig. 7) provides clues to the later Cenozoic history of the mapped area.

Hills in the upland tract in the northeastern part of the mapped area are an extension of the Gabilan Range. Hill and ridge tops there are conspicuously even (fig. 8) and represent a dissected old land surface that, if restored, would strike northwest and slope southwest about 125-180 ft per mile (A, fig. 7). The reconstructed surface is remarkably uniform; the regularity of the surface is noticeably disrupted only near the San Miguel quadrangle, where some hills stand prominently above the reconstructed-surface level.

Hill and ridge tops in the upland tract west and northwest of Paso Robles define a dissected old land surface that if reconstructed ( $B$, fig. 7) would be $400-$ $1,000 \mathrm{ft}$ above the nearby lowland area and would terminate along the Jolon-Rinconada fault zone. Tierra Redonda Mountain is well above the general level of the reconstructed surface; this fact suggests that the mountain was a topographic high on the old land surface. Even-crested hills in the upland area near the south edge of the mapped area ( $\mathrm{C}$, fig. 7) define a similar old land surface.

The Salinas River and its larger tributaries in and south of the Bradley quadrangle are flanked by a lowland area of moderate relief (fig. 3) that generally is 200-300 $\mathrm{ft}$ high; in places the lowland area may be as high as $500 \mathrm{ft}$ above the streams. Hills and flat areas between canyons in this lowland area have accordant levels that probably are remnants of a dissected old land surface. Distribution of the remnants with respect to the Salinas, San Antonio, Nacimiento, and Estrella Rivers implies that these streams once flowed on the old land surface in the lowland area. In contrast, old land surfaces in the upland tracts (fig. 7) apparently antedate modern streams.

Accordant ridge and hill tops in the upland tract north of the San Antonio River (fig. 3) define a broad arch that if restored would be 6-8 miles wide and generally as high as 1,500-2,000 $\mathrm{ft}$ above the bordering lowland areas. Surface profiles across the upland tract (pl. 2, structure sections $\mathrm{F}-\mathrm{F}^{\prime}, \mathrm{G}-\mathrm{G}^{\prime}, \mathrm{H}-\mathrm{H}^{\prime}$ ) outline the arch, which lacks broad areas of moderate relief except along the crest. Semas Mountain, which appears to be the southeasternmost tip of the arch, is severed from the main feature by the Salinas River. 
Accordant ridges and isolated flat areas in the northwest part of the mapped area probably are evidence of one or more dissected old land surfaces, but reconstruction of these surfaces is difficult.

\section{STRATIGRAPHY}

Sedimentary rocks in the southern Salinas Valley area range in age from Cretaceous to Pliocene and Pleistocene(?). Pre-Miocene rocks are unlike on the two sides of the Jolon-Rinconada fault zone. Cretaceous and Paleocene beds are recognized in the mapped area only southwest of the fault zone, where their base is concealed and the character of subjacent rocks is unknown; Eocene and Oligocene(?) beds are recognized only northeast of the fault zone, where they and younger beds overlie granitic and metamorphic rocks of the pre-Tertiary basement complex. The distribution of units that lie on the basement complex northeast of the Jolon-Rinconada fault zone (fig. 9) suggests progressive burial of an irregular basement-complex surface by Tertiary sediments. Beds near the basement complex invariably are sandy or conglomeratic, although stratigraphically equivalent beds farther away from the basement commonly are finer grained; the lithologic contrast between sandy and finer grained beds is the basis for subdivision of the Miocene strata.

Age assignment and correlation of collections of larger invertebrate fossils from Tertiary localities are in terms of the Pacific coast megainvertebrate sequence of Weaver and others (1944, chart 11), with subsequent modifications by Corey (1954) and Durham (1954). European series-epoch terminology therefore reflects the provincial age classification of these reports. Tertiary stages of the Pacific coast megainvertebrate sequence are enclosed in quotation marks as a means of differentiating them from rock-stratigraphic units bearing the same name, and, for post-Eocene stages, to indicate that they are not formally defined. Pliocene age assignments are based on an informal two-fold subdivision of the epoch (Durham and Addicott, 1965, p. A16-A17; Zullo, 1969, p. 2-3; W. O. Addicott, written commun., 1971).

Fossil localities are shown in figures 12, 18, 22, 23, and 32 ; more exact locations and additional data are given in section on "Collection Locality Descriptions."

Sedimentary rocks in the mapped area are assigned to 11 rock-stratigraphic units that are defined by a combination of lithologic character and stratigraphic position general enough to apply throughout the area (fig. 10). The stratigraphic succession varies considerably from one part of the area to another; nowhere are all of the units listed for either side of the JolonRinconada fault zone present in a single stratigraphic sequence. The stratigraphic nomenclature used here differs from the nomenclature of some earlier reports (fig. 11).

\section{PRE-TERTIARY BASEMENT COMPLEX}

Cenozoic strata lie on a basement complex composed of granitic and associated metamorphic rocks, typical of the Salinian block (fig. 37), that crops out in the north, northwest, and southeast parts of the mapped area (pl. 1). Reports of granitic-rock outcrops between San Marcos Creek and the San Antonio River (Fairbanks, 1894, p. 517; Vander Leck, 1921, p. 86) undoubtedly resulted from confusion of huge boulders of granitic rock in the Tierra Redonda Formation (fig. 21) with basement-complex outcrops. Presence of the basement complex beneath a sedimentary-rock cover northeast of the Jolon-Rinconada fault zone is confirmed by information from wells (pl. 3). Outcrop and well information concerning basement rocks southwest of the fault zone is lacking, but gravity data suggest that sedimentary rocks there may overlie and conceal the Franciscan Formation rather than Salinian-block basement complex (Burch and Durham, 1970, p. B13).

\section{METAMORPHIC ROCKS}

Gneiss and schist are the most common metamorphic rocks exposed in the mapped area. Schist is conspicuous north of Paraiso Springs and east of King City; gneiss is abundant in the Junipero Serra Peak and Reliz Canyon quadrangles. Crystalline limestone crops out south of the Arroyo Seco near Horse Canyon and locally farther east. Compton (1966b, p. 1364) reported that metamorphic rocks in and near the Junipero Serra 15-minute quadrangle "were metamorphosed to highest-grade amphibolite facies and granulite facies," and "are mainly medium-grained quartzites, quartzo-feldspathic gneisses and granofelses*** amphibolites, pelitic schists, marbles, and metadolomites." On the basis of present associations and bulk compositions, about 70 percent of the original sedimentary rocks were feldspathic or argillaceous sandstones and siltstones associated with argillaceous limestones and dolomites, calcium-poor claystones, nearly pure limestones and dolomites, and quartzose sandstones (Compton, 1966a, p. 278). Christensen (1963, p. 111) described coarse-grained muscovite quartzites and schistose fine- to medium-grained biotite-muscovite metasandstones from the basement complex at the south end of the Gabilan Range near San Lorenzo Creek and mentioned (p. 112) that granitic rock from about $31 / 2$ miles east of Greenfield contains poikilitic feldspars that suggest metamorphic rock. 


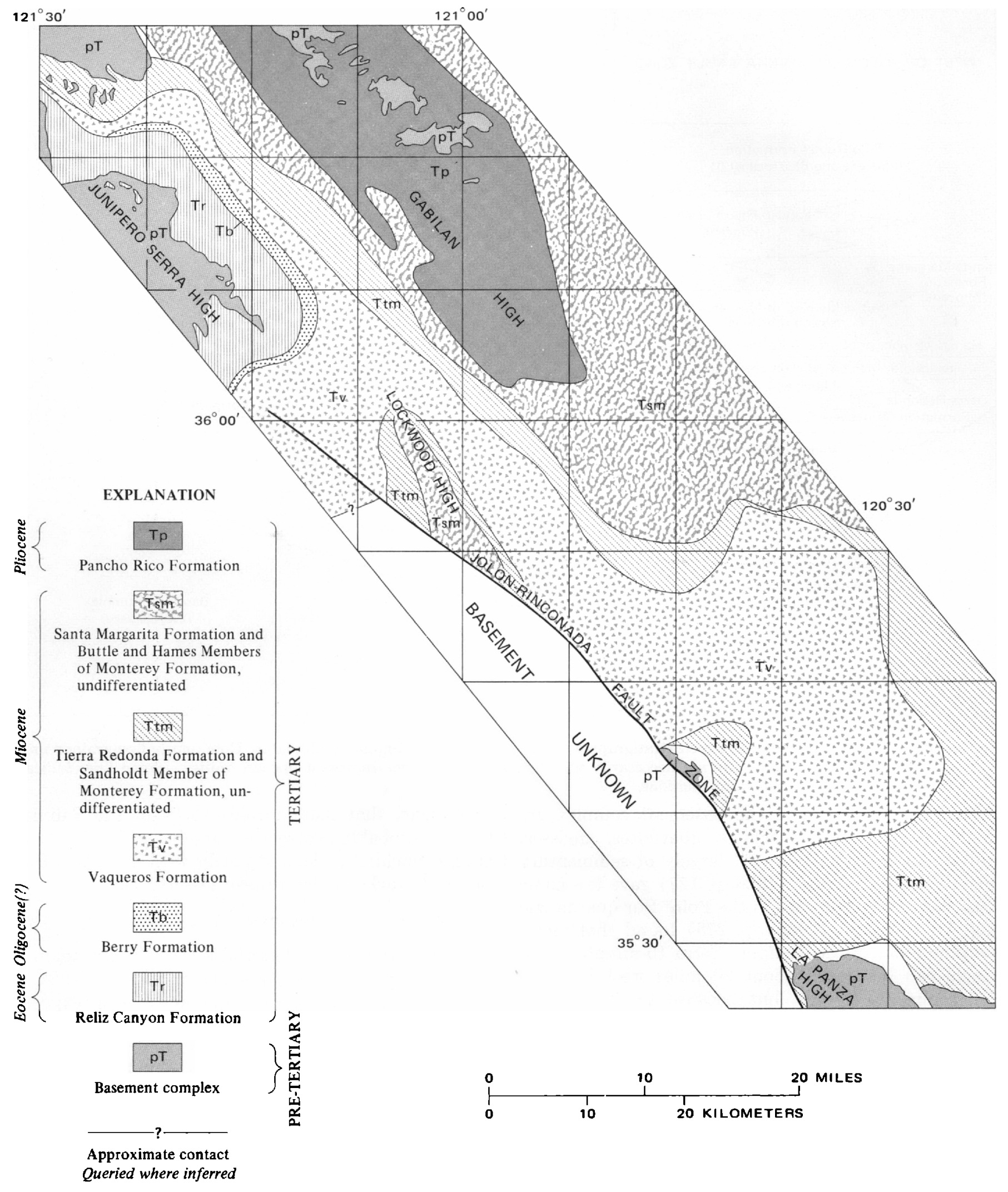

FIGURE 9.-Approximate distribution of units that lie on the basement complex northeast of the Jolon-Rinconada fault zone. The units are the ones shown in the subsurface on structure sections (pl. 2); the Paso Robles Formation and alluvium are omitted. (Quadrangles identified in fig. 2) 


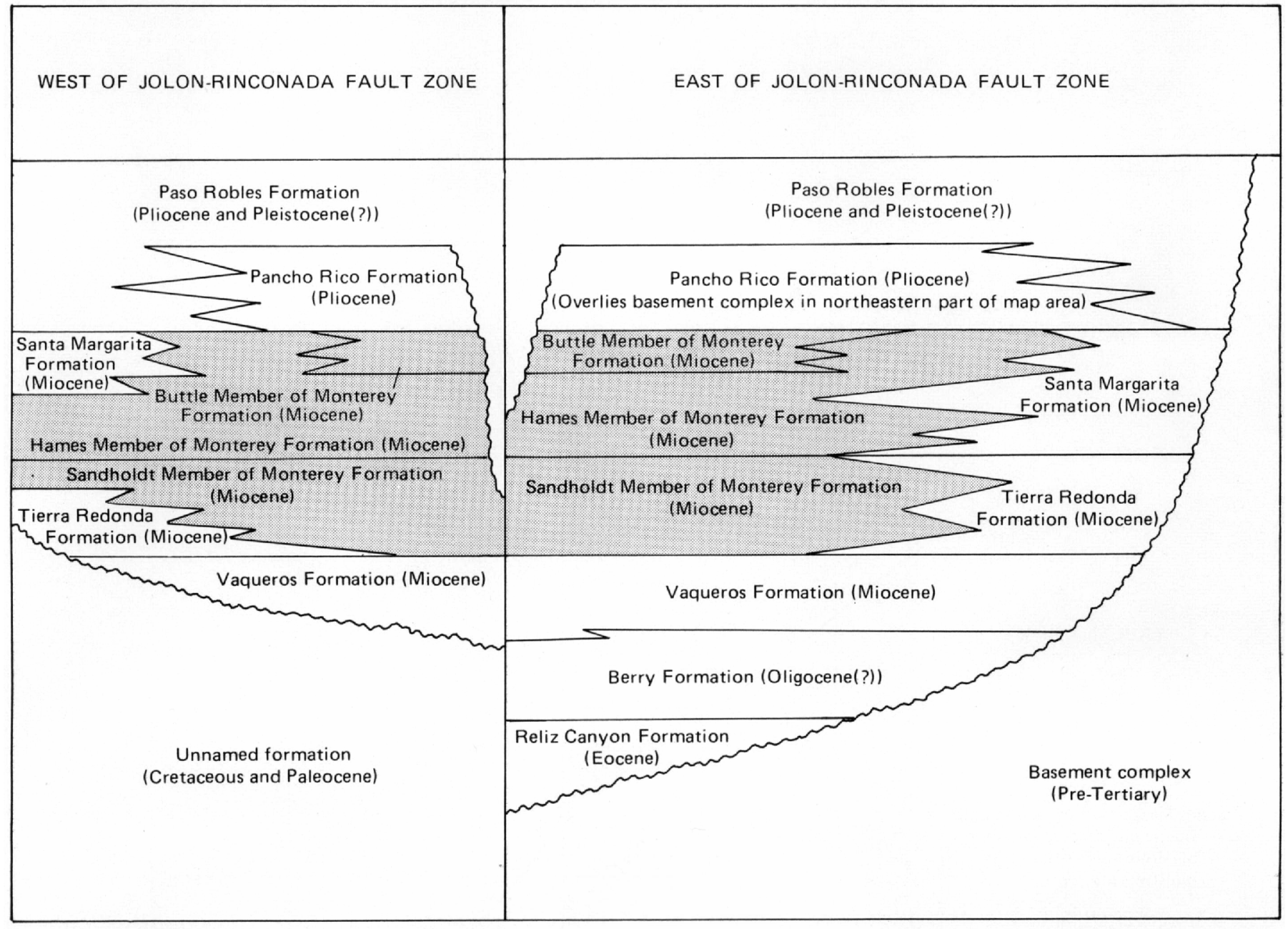

FIGURE 10.-Generalized relations of rock-stratigraphic units in the southern Salinas Valley area. Dominantly fine-grained units are shaded. Horizontal lines are not necessarily time horizons; wavy lines represent unconformities; jagged lines indicate lateral gradation or intertonguing relations.

Metamorphic rocks in the basement complex are similar to "a series of schists, quartzites, gneisses, and crystalline limestones*** largely of sedimentary origin" to which Trask $(1926$, p. 127) gave the name "Sur Series" for outcrops in the Point Sur quadrangle (fig. 1). Compton (1966a, p. 278) found that metamorphic rocks of the Junipero Serra 15-minute quadrangle can be traced about 20 miles west into the Point Sur quadrangle, but because the term "Sur Series" is poorly defined, it is not used in this report.

The metamorphic rocks are of unknown age, but they obviously antedate the Cretaceous granitic rocks that intrude them. According to Compton (1966b, p. 1366), they underwent two severe deformations that involved "folding, deep-seated metamorphism, and emplacement of plutonic igneous rock," all before latest Cretaceous time. Wiebe (1970, p. 1841) concluded, on the basis of lithologic similarities and allowance for large displacement along the San Andreas

fault zone, that metamorphic rocks of the Salinian block "probably correlate largely with Paleozoic miogeosynclinal rocks and partly with presumed Precambrian rocks of the Mojave Desert" (fig. 1).

\section{GRANITIC ROCKS}

Coarse-grained varieties of the granodiorite, adamellite, and granite clans (Williams and others, 1954, p. 121-148) are the most common granitic rocks exposed in the southern Salinas Valley area. Pegmatite and aplite dikes and quartz dikes and veins are common in the basement complex; some deeply weathered granitic rocks are most easily identified in the field because of included dikes.

According to Compton (1966b, p. 1365), plutons in the Junipero Serra 15-minute quadrangle "consist chiefly of adamellite, granodiorite, and tonalite, with some potassic granite and basic-to-ultrabasic rocks"; the rock texture ranges from granular to gneissose. 


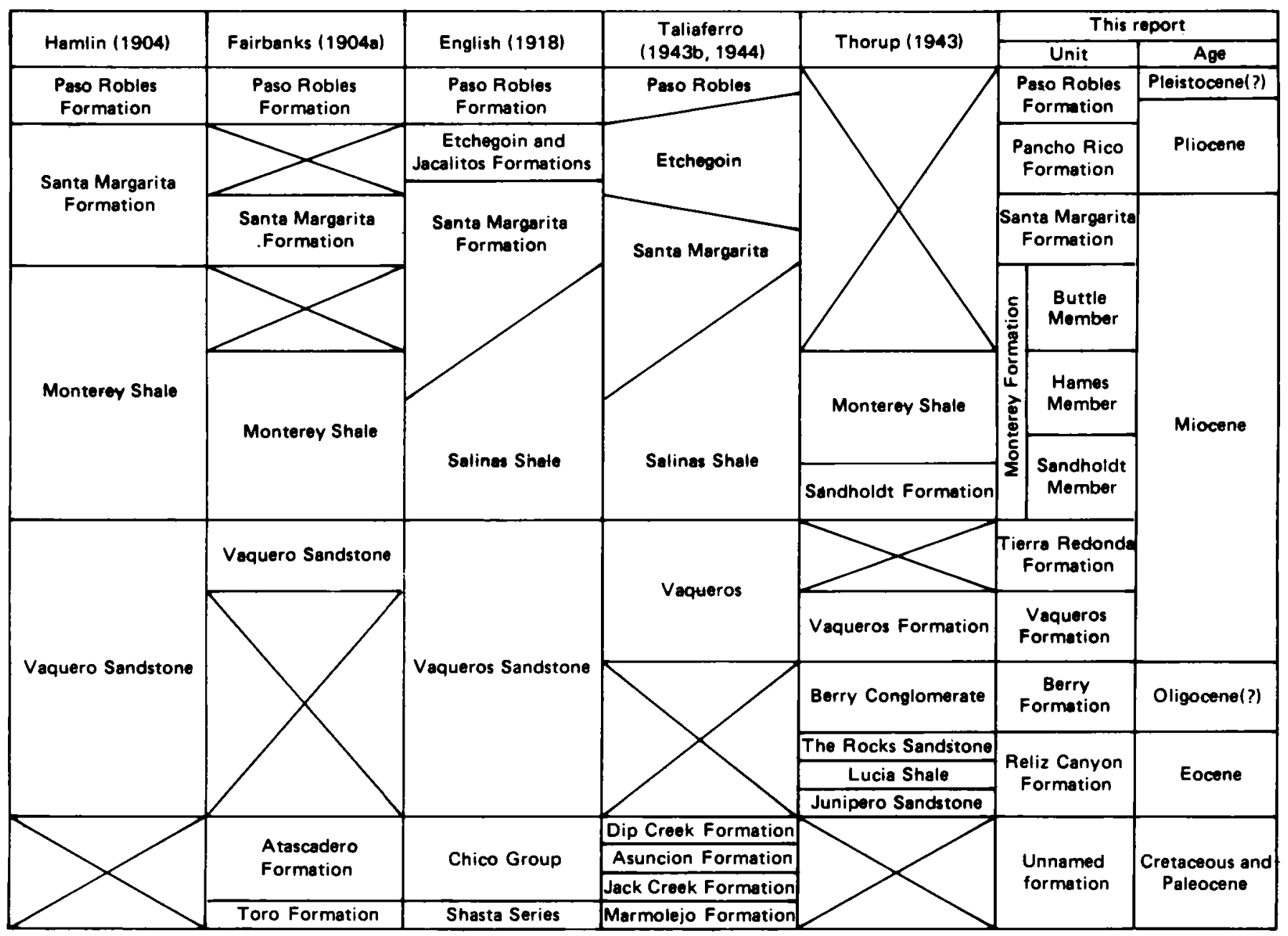

FIGURE 11.-Stratigraphic nomenclature in the southern Salinas Valley area.

Compton (1966a, p. 285) also mentioned a body of quartz diorite at the south end of the Gabilan Range, and he described (p. 277) adamellite from the La Panza Range.

Christensen (1963, p. 111) described biotite granite from the south end of the Gabilan Range near San Lorenzo Creek (NW1/4 sec. 15, T. 19 S., R. 9 E.) that contains large poikilitic orthoclase-perthite crystals, quartz, plagioclase, and biotite, as well as zircon, apatite, and titanite accessory minerals. He also described coarse-grained biotite-hornblende granodiorite from nearby (SW $1 / 4$ sec. 10 , T. 19 S., R. 9 E.), and $(1963$, p. 112$)$ fine- to coarse-grained biotite granite from about $31 / 2$ miles farther northwest (NE $1 / 4$ sec. 1, T. 19 S., R. 8 E.).

Granitic rocks occur in all major outcrop areas of the basement complex in the mapped area. At some places they form plutons, as around Pinyon Peak near the west edge of the Reliz Canyon quadrangle; at other places, they are iitimately mixed with metamorphic rocks. Compton (1966b, p. 1364) noted that in the Junipero Serra 15-minute quadrangle, granite dikes form 5-50 percent of most outcrops in the metamorphic rock terrane. He also stated (p. 1365) that some plutons in the quadrangle "are sharply bounded, whereas others grade broadly to diked metamorphic rocks."

Published radiometric ages for granitic rocks in the mapped area are lacking, but $\mathrm{K}$-Ar age determinations from nearby areas are helpful for establishing the apparent age of the rocks. Compton (1966a, p. 278) reported radiometric ages of 70.2 and $69.0 \mathrm{~m} . \mathrm{y}$. (million years) for biotite from quartz diorite collected about three-quarters of a mile southwest of the southwest corner of the Reliz Canyon quadrangle, and 75.0 m.y. for biotite from pyroxene-biotite-plagioclase granofels from about $7 \frac{1}{2}$ miles farther southwest at the summit of Cone Peak (fig. 1). Curtis, Evernden, and Lipson (1958, p. 9) gave a radiometric age of 83.8 m.y. for quartz diorite from about $3 \frac{1 / 2}{2}$ miles north of the 
Greenfield quadrangle in the Gabilan Range; Compton (1966a, fig. 1) recalculated this figure to $79.9 \mathrm{~m} . \mathrm{y}$. Curtis, Evernden, and Lipson (1958, p. 10) also gave a radiometric age of $84.1 \mathrm{~m} . y$. for granodiorite from about $1 \frac{1}{2}$ miles south of the center of the Santa Margarita quadrangle in the La Panza Range; Compton (1966a, fig. 1) recalculated this figure to $80.2 \mathrm{~m} . \mathrm{y}$. All these apparent ages fall within the last half of the interval from about 65 to $136 \mathrm{~m} . \mathrm{y}$. before the present that generally is accepted as the age range for the Cretaceous Period (Harland and others, 1964). From these data, we know that granitic rocks of the southern Salinas Valley area are of Cretaceous, probably Late Cretaceous, age; however, Compton (1966a, p. 287) suggested that the youngest ages represent a "postgranite event, for example the deformation that produced the fine-grained recrystallized marbles."

\section{CRETACEOUS AND TERTIARY SYSTEMS}

\section{UNNAMED FORMATION}

\section{NOMENCLATURE}

The oldest strata in the southern Salinas Valley area constitute an unnamed formation of Cretaceous and Paleocene age. The unit includes beds that Fairbanks (1904a, p. 3) called Toro and Atascadero Formations, and Taliaferro (1944, p. 458, 475, 486, 512) named Marmolejo, Jack Creek, Asuncion, and Dip Creek Formations. Fairbanks (1904a, p. 3) considered his Toro Formation "the local representative of the Knoxville Group" and his Atascadero Formation "the local representative of the Chico Group." Taliaferro (1944, p. 459) used the name "Marmolejo Formation" for the "Lower Cretaceous of the Santa Lucia Range," the name "Jack Creek Formation" as a "local formational name for the representative of that part of the [lower Upper Cretaceous] Pacheco Group present in the Santa Lucia Range" (p. 474), and the names "Asuncion Group" and "Asuncion Formation" for "coarse clastics deposited after the [middle-late Cretaceous] Santa Lucian orogeny and resting unconformably on all the older rocks" (p. 474). Taliaferro (1944, p. 513) applied the name "Dip Creek Formation" to "the Paleocene beds in the central and south Santa Lucia Range." The unnamed formation belongs mainly to the Asuncion and Dip Creek Formations of Taliaferro; a few small outcrop areas of the Franciscan Formation in the Atascadero quadrangle are included in the unnamed formation on the geologic map (pl. 1).

\section{DISTRIBUTION AND THICKNESS}

The Cretaceous and Paleocene unnamed formation has been identified in the mapped area only south- west of the Jolon-Rinconada fault zone (fig. 12), but Turritella pachecoensis, which is restricted to the Paleocene Martinez Stage of Weaver and others (1944) in the Pacific Coast megainvertebrate sequence, occurs just west of the mapped area. (See following localities, W. O. Addicott, written communs., 1963, 1967.)

USGS Locality M1677 (field No. 624380). On ridge, $725 \mathrm{ft} \mathrm{S.,}$ $300 \mathrm{ft}$ E. of NW. cor. sec. 36, T. 21 S., R. 5 E., Cone Peak quadrangle (SW1/4 Junipero Serra 15-minute quadrangle). Fossils: mollusks. Collectors: D. L. Durham and D. C. Wiese, 1962.

USGS locality M2901 (field No. 664089). Along road, 2,650 ft S., 1,200 ft E. of NW. cor. sec. 12, T. 20 S., R. 4 E., Junipero Serra Peak quadrangle. Fossils: mollusks. Collectors: D. L. Durham and R. L. Bendixon, 1966.

An unpublished report of Paleocene fossils in the mapped area near Coleman Canyon (Nicholls, 1924) has not been verified, but the reported occurrence suggests that some of the beds there assigned to the Reliz Canyon Formation may be Paleocene. (Nicholls listed the following fossils from his loc. 18, near SE. cor. sec. 10, T. 21 S., R. 6 E., Bear Canyon quadrangle: Turritella pachecoensis, Turritella infragranulata, Turritella susanaensis, Cucullaea mathewsonii, Phacoides diaboli, Ampullaspira martinezensis, Cardium lintium, brachiopod, small oyster. The fossils were collected by O. G. McDonald and E. N. Pennebaker in 1923.)

The thickness of the unnamed formation is unknown because the base of the unit is concealed and wells have failed to reach the rocks beneath. Data from the Reserve Oil and Gas Devries 37-25 well (pl. 4, No. 528) suggest a thickness greater than 7,000 feet; the well spudded at least 2,500 feet below the top of the formation, drilled 5,200 ft, apparently through moderately dipping beds, and did not reach the base of the unnamed formation.

\section{LITHOLOGY}

The unnamed formation contains conglomerate, sandstone, siltstone, and mudstone. Sandstone is the most common; conglomerate is interbedded with the sandstone at many places, and locally it forms most of the formation. Mudstone and siltstone are less common than either sandstone or conglomerate, but they too are abundant locally; the distribution of rock types in the formation seems unrelated to stratigraphic position. The composition of the clasts indicates that the unit was derived from the Salinian-block basement complex rather than from the Franciscan Formation. In many areas the unnamed formation forms bold ridges, cliffs, and bare dip slopes, but in other areas it underlies rounded hills that have few exposures. The plant cover ranges from grass to dense chaparral.

The sandstone is fine to coarse grained, and some 


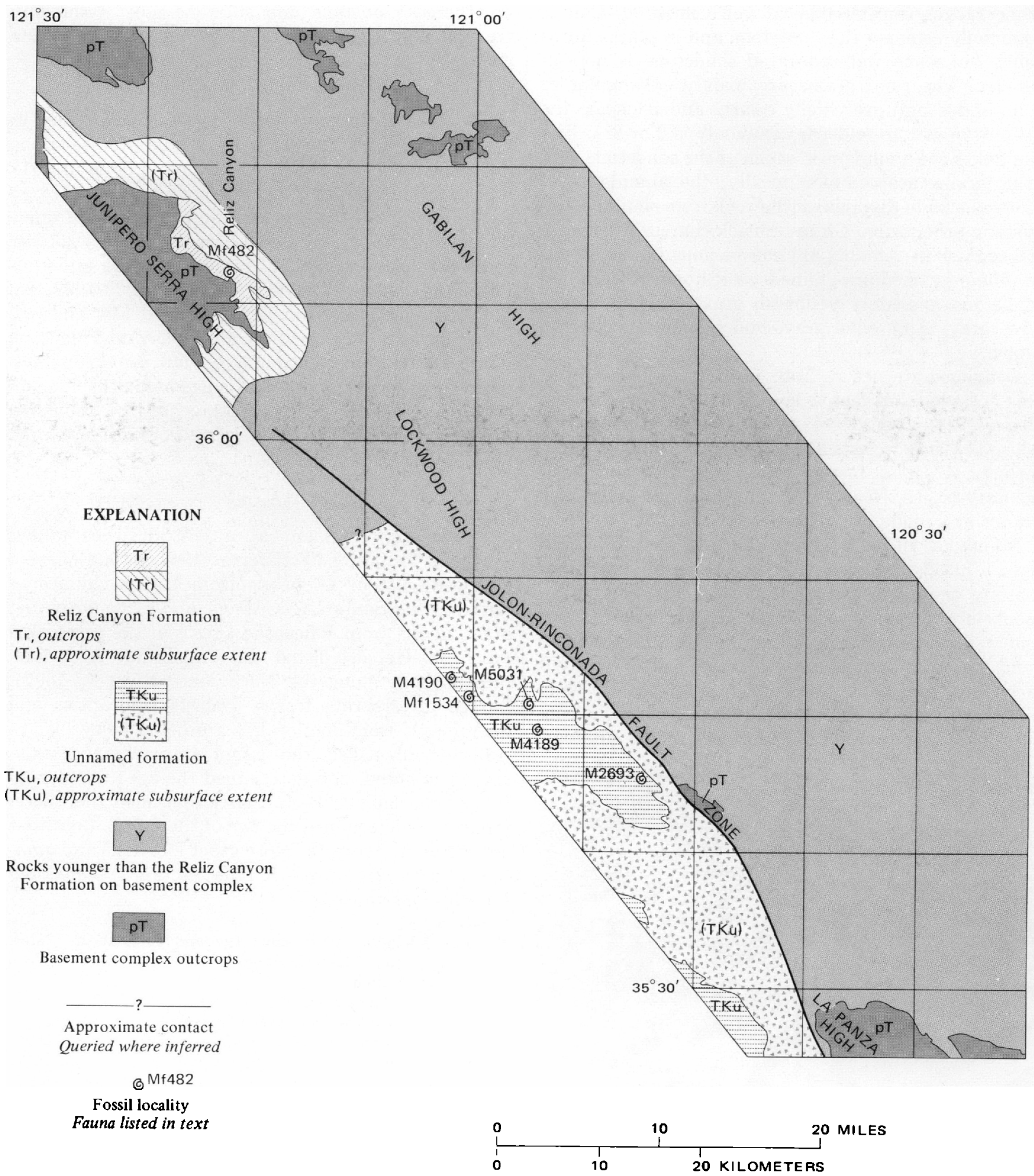

Figure 12.-Approximate distribution of the unnamed formation of Cretaceous and Paleocene age, and the Reliz Canyon Formation in the southern Salinas Valley area. Small outcrop areas are omitted (quadrangles identified in fig. 2).

is conglomeratic. The coarse-grained rock, generally $\mid$ in contrast, the fine-grained rock is more commonly poorly sorted, forms massive beds as thick as 3-10 ft; $\mid$ well sorted, well bedded, and thin bedded. The sand- 
stone ranges from friable to well cemented. Calcite commonly cements the sandstone and in places forms veins, but some well-indurated sandstone is noncalcareous. The sand grains are mainly subangular or subrounded and are chiefly quartz and feldspar; the ratio of quartz to feldspar commonly is 2 or $3: 1$. Biotite flakes are abundant in much of the sandstone, and lithic grains are common locally; the abundance of biotite helps to distinguish the rock from similar sandstone in other units. Chips of black charcoallike material and plant remains are conspicuous in some beds of fine- to medium-grained sandstone. Weathered sandstone is mainly yellowish gray, grayish orange, olive gray, light olive gray, and moderate yellowish brown.

Conglomerate occurs both in massive beds and in sets of beds a few feet to several tens of feet thick; it also occurs as thin streaks and lenses in sandstone beds. The larger clasts are generally well rounded and include volcanic, metamorphic, granitic, and sedimentary rocks. Weathered conglomerate is grayish orange and moderate yellowish brown.

Mudstone and siltstone in the unnamed formation have a hackly fracture habit and generally are either massive or in beds 1-6 in. thick (fig. 13). They commonly are noncalcareous, or only slightly calcareous, and well indurated. The mudstone contains scattered sand grains and abundant small mica flakes; locally it is pebbly. Limestone beds and concretions are associated with the mudstone locally. Plant debris is conspicuous on certain bedding surfaces in the siltstone.

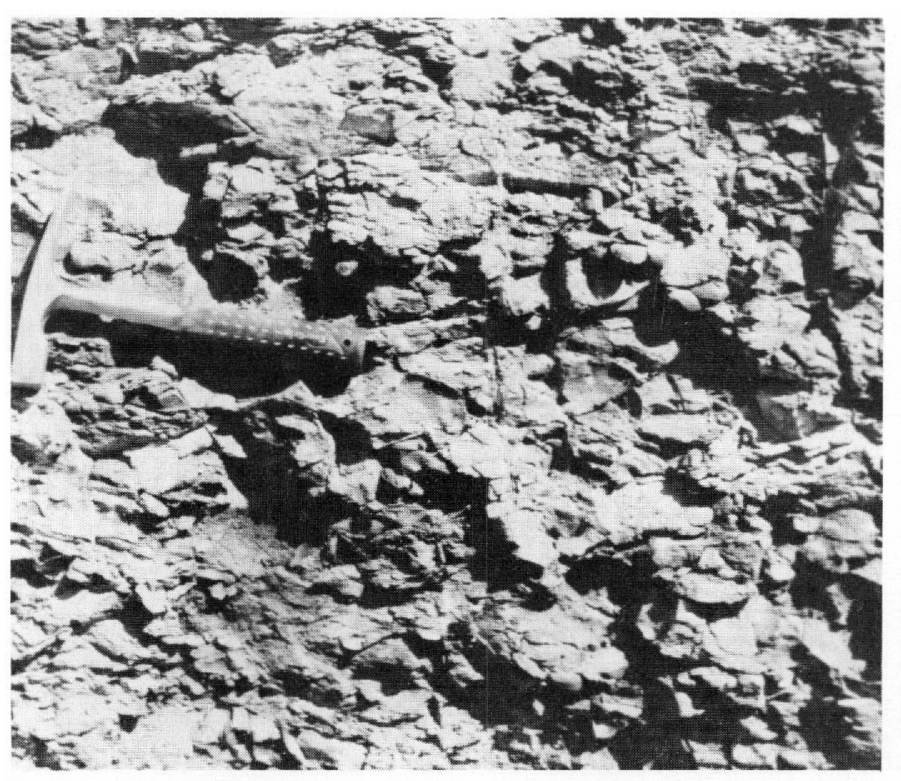

Figure 13.- Hackly mudstone in the unnamed formation of Cretaceous and Paleocene age at fossil locality Mf1534, along Kavanaugh Creek, Bryson quadrangle.
Weathered mudstone and siltstone most commonly are olive gray, light gray, reddish brown, and yellowish gray.

\section{STRATIGRAPHIC RELATIONS}

The base of the unnamed formation is concealed in the mapped area, and wells have failed to reach the rocks beneath the unit. Dickinson $(1965$, p. 31) reported that marine Paleocene beds near the Arroyo Seco just west of the Junipero Serra Peak quadrangle lie unconformably on crystalline rocks, but farther south a thick sequence of Cretaceous strata underlies Paleocene beds. Taliaferro $(1944$, p. $457,469,484$, 517) described three major unconformities and one minor unconformity in the Cretaceous and Paleocene strata of the Santa Lucia Range, but convincing evidence of these unconformities is lacking in the mapped area. Geophysical data indicate that the unnamed formation overlies the Franciscan Formation (Burch and Durham, 1970, p. B13).

\section{FOSSILS}

Fossils are abundant at a few localities in the unnamed formation. Taliaferro $(1944$, p. 502) gave a composite list of 24 fossils from Upper Cretaceous strata in the Santa Lucia Range, and a composite list of 12 fossils from Paleocene strata in the same area (p. 516). He also listed six foraminifers from Cretaceous beds along the Nacimiento River (p. 505). Larger invertebrate fossils from four localities and microfossils from one locality are listed below. W. 0 . Addicott identified the larger invertebrate fossils, except as noted, and determined the age and correlation of the faunas; R. L. Pierce identified the microfossils and determined the age of the fauna. Localities are shown in figure 12. More exact locations and additional data are given in the section "CollectionLocality Descriptions."

USGS loc.

M2693. Adelaida quadrangle. Age and correlation: Paleocene, "Martinez Stage."

\section{Gastropods:}

Amauropsis martinezensis Dickerson?

Mesalia martinezensis (Gabb)

Priscoficus cf. P. caudata (Gabb)

Tornatellaea pinguis (Gabb)

Turritella infragranulata Gabb

Pelecypods:

Cucullaea mathewsoni Gabb

Nemocardium cf. $N$. linteum (Conrad)

M4189. Lime Mountain quadrangle. Age: Cretaceous or Paleocene.

Gastropods:

Ampullina concipio Dailey and Popenoe ${ }^{1}$

Anchura sp.1

Turritella cf. T. chicoensis perrini Merriam peninsularis Anderson and Hanna 
USGS loc. M4189.

Pelecypod:

Venericardia cf. $V$. venturensis Waring ${ }^{1}$

M4190. Bryson quadrangle. Age: Late Cretaceous. Gastropods:

"Concothyra" hamula (Gabb) 1

Turritella cf. T. chicoensis perrini Merriam peninsularis Anderson and Hanna

Pelecypods: Ostrea sp.

M5031. Tierra Redonda Mountain quadrangle. Age: Late Cretaceous.

Gastropods:

Pugnellus sp.2

Tessarolax sp. ${ }^{2}$

Turritella cf. T. chicoensis perrini Merriam peninsularis Anderson and Hanna

Pelecypods:

Glycymeris?

Septifer cf. S. susanaensis Nelson

Solen?

Scaphopod:

Dentalium sp.

Cephalopod: Baculites sp.

Mf1534. Bryson quadrangle. Age and correlation: Late Cretaceous, probably lower Maestrichtian or Campanian Stage.

Foraminifers:

Allomorphina cf. A. cretacea Reuss

Bathysiphon sp.

Cribrostomoides cretaceous Cushman and Goudkoff

Dorothia ellisorae (Cushman)

Gaudryina bentonensis (Carman) cf. G. tailleuri (Tappan)

Haplophragmoides cf. H. excavatus Cushman

Praebulimina kickapooensis (Cole)

Reophax sp.

Silicosigmoilina californica Cushman and Church

Spiroplectammina cf. S. chicoana Laliker

Radiolarians:

Dictyomitra multicostata Zittel

IIdentified by W. P. Popenoe.

Identified by N. F. Sohl.

\section{AGE AND CONDITIONS OF DEPOSITION}

Fossils indicate a Late Cretaceous and Paleocene age for the unnamed formation. Because Cretaceous beds are generally indistinguishable from Paleocene beds by lithologic character, both Cretaceous and Paleocene beds are included in the mapped unit. Taliaferro (1944, p. 503-507) reviewed the opinions of several paleontologists concerning the age of the fauna from his Asuncion Formation, and he concluded (p. 508) that the fauna "represents the late Senonian and the Maestrichtian and probably extends into the Danian (using Danian in the sense of the latest stage in the Upper Cretaceous)." Popenoe, Imlay, and Murphy (1960, chart 10e) placed the Asuncion Group of Taliaferro in the Campanian and Maestrichtian Stages; they considered the Jack Creek Formation of Taliaferro as Early Cretaceous.

Fossils in the unnamed formation demonstrate the marine origin of at least part of the unit. The foraminiferal fauna in mudstone at locality Mf1534 indicates outer neritic, or deeper, water (R. L. Pierce, oral commun., 1971). The megainvertebrate assemblages are indicative of a shallower, inner neritic environment (W. O. Addicott, written commun., 1971). The coarseness and poor sorting of some sandstone and conglomerate beds suggest shallow-water conditions; red beds give parts of the formation a nonmarine aspect.

\section{TERTIARY SYSTEM}

\section{EOCENE SERIES}

\section{RELIZ CANYON FORMATION}

\section{NOMENCLATURE}

The stratigraphically lowest beds in the northwestern part of the mapped area constitute the Reliz Canyon Formation, which is named for typical exposures in upper Reliz Canyon (Durham, 1963, p. Q7). Hamlin (1904, p. 14) included these beds in his "Vaquero Sandstone"; he named the unit for exposures 1-2 miles west of Reliz Canyon along upper Vaqueros Creek. Thorup (1941) divided the beds into three formations: The Junipero Sandstone at the base, the Lucia Shale in the middle, and The Rocks Sandstone above. These three units are here considered members of the Reliz Canyon Formation (Durham, 1963, p. Q7); at those places where the middle shaly member is absent, the upper and lower sandy members are indistinguishable. The formation is undivided on the accompanying geologic map (pl. 1).

\section{DISTRIBUTION AND THICKNESS}

The Reliz Canyon Formation crops out around basement complex exposures in the Junipero Serra Peak, Reliz Canyon, and Bear Canyon quadrangles. Well data indicate that the subsurface extent of the formation is limited to the vicinity of the outcrops (fig. 12).

The Reliz Canyon Formation in Reliz Canyon is nearly 2,000 ft thick. Estimates for the thickness of the formation outside the Reliz Canyon quadrangle are uncertain because the structure is complex, and the upper part of the unit has been removed by erosion.

\section{LITHOLOGY}

The Reliz Canyon Formation is chiefly sandstone; mudstone forms a local member in the lower part of 


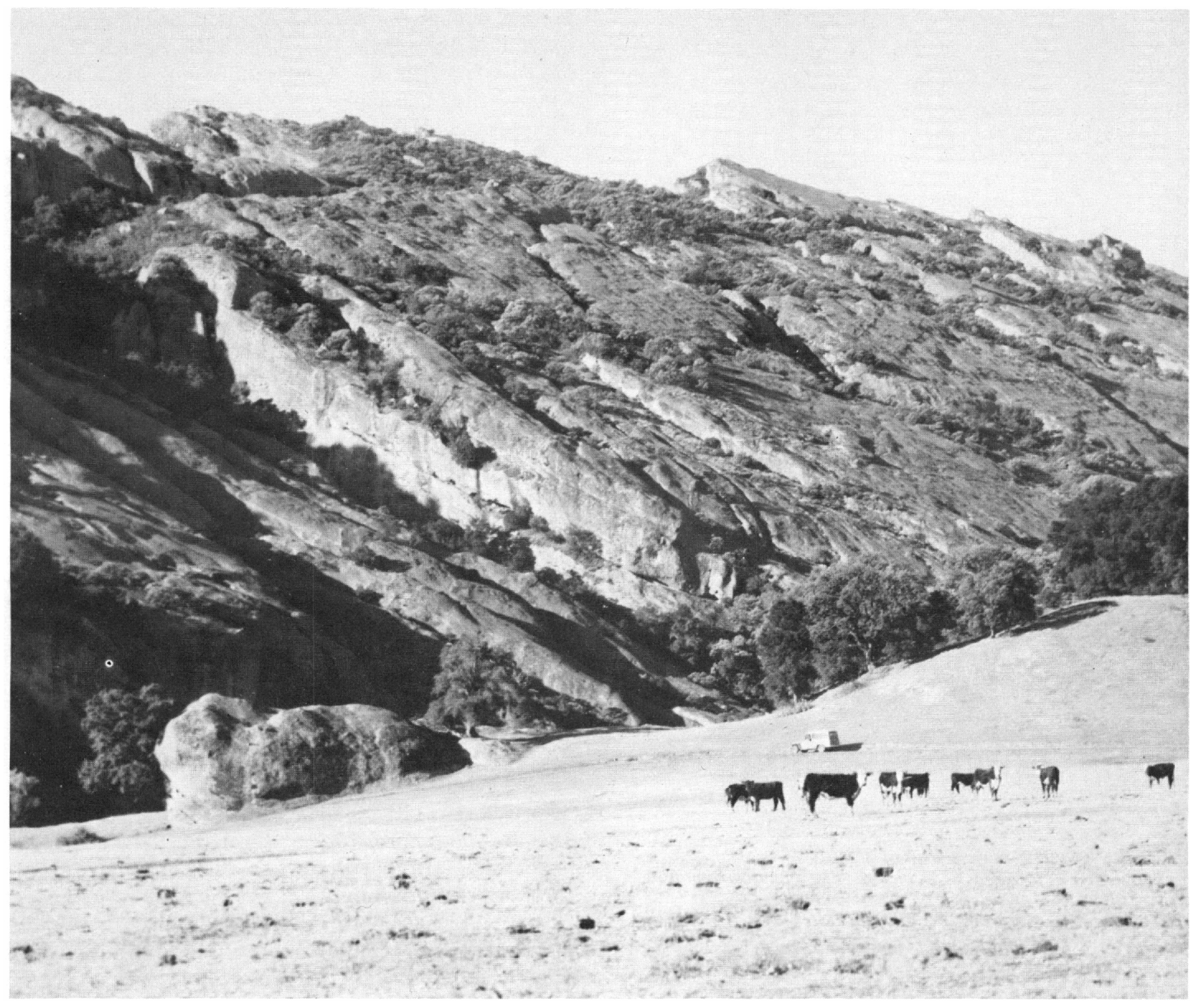

Figure 14.-Massive sandstone in the type Reliz Canyon Formation along upper Reliz Canyon, Reliz Canyon quadrangle. These huge outcrops are named "The Rocks."

the unit, and sandstone near the base is conglomeratic locally. The sandstone forms bold outcrops and huge bare slopes (fig. 14); the mudstone generally crops out poorly, except in stream banks or in artificial exposures.

The sandstone is fine to coarse grained and commonly is poorly sorted. Beds range from $2-20 \mathrm{ft}$ thick. The sandstone generally is calcareous and well cemented. Ellipsoidal limy concretions as long as $3 \mathrm{ft}$ are common and conspicuous in the upper part of the formation. The sand grains, angular to subrounded, are mainly quartz and feldspar in about equal amounts. Weathered sandstone is mainly yellowish gray, pale olive, grayish orange, and light olive gray.

Mudstone in the Reliz Canyon Formation (fig. 15) is generally massive and has a hackly fracture. It is mainly noncalcareous and well indurated, and it contains ellipsoidal limy. concretions 3-12 in. long. The rock contains scattered fine sand grains and mica flakes. Weathered mudstone is chiefly grayish orange and light olive gray, and less commonly pale yellowish brown and dusky yellow.

\section{STRATIGRAPHIC RELATIONS}

The Reliz Canyon Formation unconformably overlies the basement complex. Nowhere in the mapped area is the formation known to overlie the unnamed formation of Cretaceous and Paleocene age (fig. 12), although Compton (1957) reported that Eocene beds 


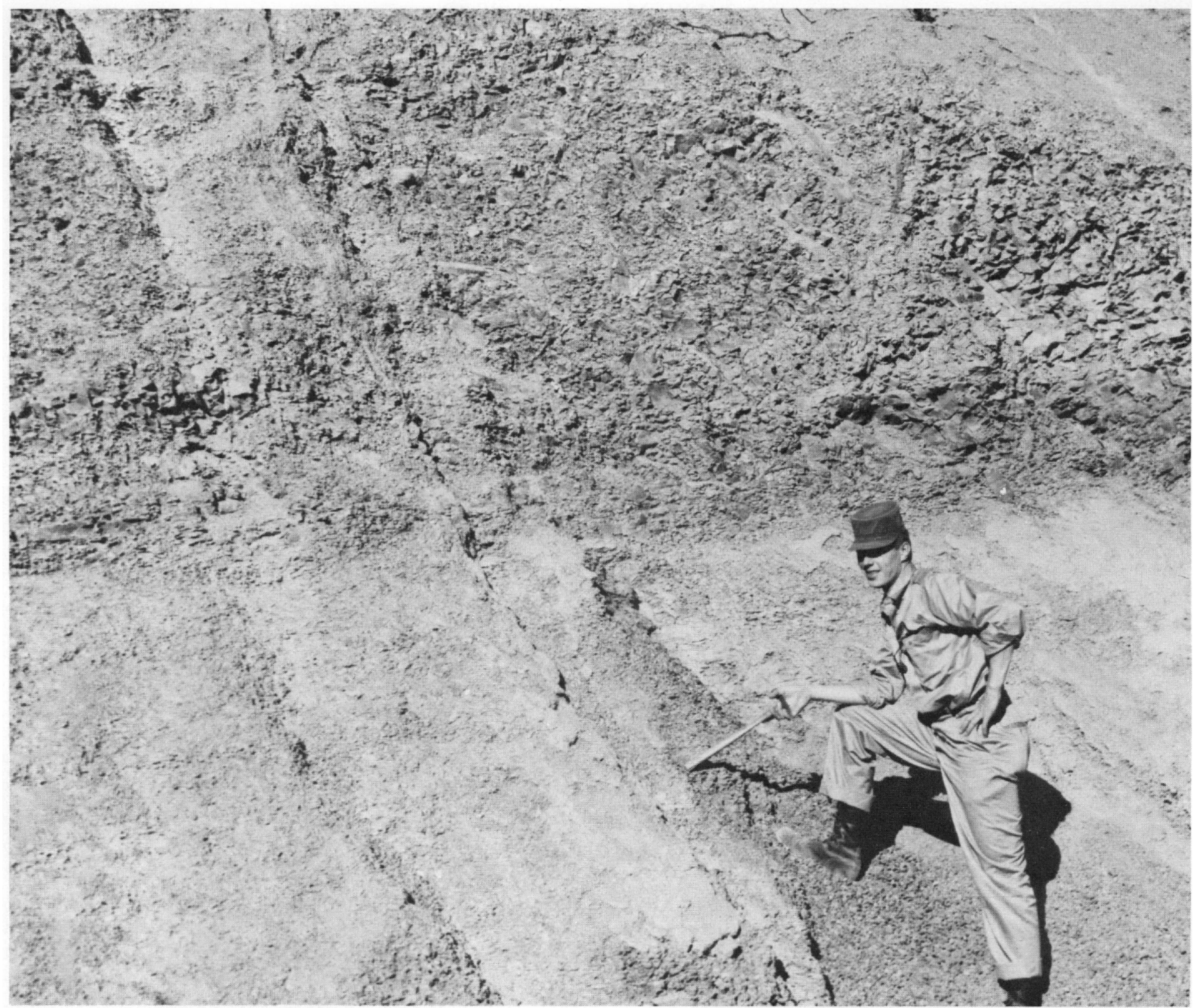

Figure 15.-Hackly mudstone in the type Reliz Canyon Formation at fossil locality Mf482 along upper Reliz Canyon, Reliz Canyon quadrangle.

unconformably overlie Paleocene sedimentary rocks just west of the area near the San Antonio River in the Junipero Serra 15-minute quadrangle. Features of the Reliz Canyon Formation that help to distinguish the unit from the unnamed formation are scarcity of conglomerate, lack of abundant biotite, massiveness of sandstone beds, and stratigraphic position below the Berry Formation.

\section{FOSSILS}

Mudstone in the lower part of the Reliz Canyon Formation contains fossil foraminifers. Mallory (1959, p. 52-53) listed the fauna, and Wardle (1957) studied foraminifers from the type locality of the unit in upper Reliz Canyon. Fossil foraminifers from U.S. Geological
Survey locality Mf482 are listed below. R. L. Pierce identified the fossils and determined the age of the fauna.

USGS loc.

Mf482. Reliz Canyon quadrangle. Age and correlation:

Eocene, probably Penutian Stage of Mallory (1959).

Foraminifers:

Ammodiscus cf. A. incertus d'Orbigny Anomalina regina Martin

Buliminella cf. B. curtissma Cushman and Siegfus grata convoluta Mallory

Cibicides spiropunctatus Galloway and Morrey

Dentalina cf. D. multilineata Bornemann

Eponides umbonata (Reuss)

Globigerina cf. G. soldadoensis Bronnimann yeguaensis Weinzierl and Applin 
Globorotalia aragonensis Nuttall cf. G. broedermanni Cushman cf. G. quetra Bolli

Hastigerina micra Cole

Karreriella cf. K. arenasensis Cushman and Bermudez

Loxostomum applinae (Plummer)

Martinottiella eocenica Cushman and Bermudez

Nodosarella ignota Cushman and Siegfus

Nodosaria cf. N. latejugata Gümbel

Parrella culter midwayana (Cushman and Todd)

Plectofrondicularia kerni Cook

Rhabdammina eocenica Cushman and G. D. Hanna

Spiroplectammina richardi Martin

Trifarina advena californica Mallory

Trochammina cf. T. globigerinaformis (H. B. Brady)

Vaginulinopsis asperuliformis (Nuttall)

Verneuiliana triangulata Cook

\section{AGE AND CONDITIONS OF DEPOSITION}

Foraminifers in mudstone in the lower part of the Reliz Canyon Formation indicate an Eocene age. The fauna from locality Mf482 is most characteristic of the Penutian and lower Ulatisian Stages of Mallory (1959), and therefore it probably indicates an early Eocene age (R.L. Pierce, written commun., 1968). The faunal locality is near the base of the formation, therefore, the oldest beds in the unit are probably also early Eocene. Mallory (1959, p. 53) assigned the fauna from Reliz Canyon that he listed to his Ulatisian Stage; Wardle (1957) assigned faunas from Reliz Canyon to the "Juniperan" (Penutian) and lower Ulatisian Stages of Mallory (1959).

The upper limit of the age range of the Reliz Canyon Formation is uncertain because the upper part of the unit lacks fossils, and so does the overlying Berry Formation. However, the Vaqueros Formation, which overlies the Berry, contains Miocene fossils, consequently, both the Berry and the upper part of the Reliz Canyon Formation are limited to an age no younger than early Miocene. If, as seems likely, the Berry is at least partly Oligocene, then the upper part of the Reliz Canyon is no younger than Oligocene. For convenience, and for want of direct contradictory evidence, the Reliz Canyon Formation is considered Eocene on the basis of forminifers in the lower part.

Foraminifers in mudstone in the lower part of the Reliz Canyon Formation establish that at least part of the unit is marine. The foraminiferal fauna at locality Mf482 indicates probable bathyal depth (R. L. Pierce, oral commun., 1971). Sandstone that forms the bulk of the formation appears to be marine; although it lacks fossils, it also lacks the crude bedding, crossstratification, and channels that are common in nonmarine sediments.

\section{OLIGOCENE(?) SERIES}

\section{BERRY FORMATION}

\section{NOMENCLATURE}

The Berry Formation overlies the Reliz Canyon Formation in the conformable stratigraphic succession exposed in the northwestern part of the mapped area. Thorup $(1941,1943)$ gave the name "Berry Conglomerate" to beds between the Reliz Canyon and Vaqueros Formations in the Reliz Canyon quadrangle, and he gave (1941) as the type locality the $\mathrm{SE}^{1 / 4}$ sec. $26, \mathrm{~T}$. 20 S., R. 6 E., in upper Reliz Canyon. Bramlette and Daviess (1944) used the name "Berry Formation" for the same beds. The unit was considered a lower, unnamed nonmarine member of the Vaqueros Formation in previous reports (Durham, 1963, p. Q9; 1964, p. $\mathrm{H6}$ ), largely because it is limited in areal extent and intertongues with the Vaqueros, but because the beds are distinct, they are here considered a formation. Bramlette and Daviess' term (1944) "Berry Formation" is preferred to the name "Berry Conglomerate" because the unit contains appreciable amounts of sandstone and mudstone in addition to conglomerate.

\section{DISTRIBUTION AND THICKNESS}

The Berry Formation crops out near basementcomplex exposures in the Junipero Serra Peak, Reliz Canyon, Bear Canyon, and Cosio Knob quadrangles, and it probably is restricted to the same vicinity (fig. 16) in the subsurface. Although the terms "Berry Formation" and "Berry Conglomerate" have been applied to conglomerate and red beds over much of the mapped area, the use of the name "Berry" is here restricted to beds in the stratigraphic context of the type locality, that is, to beds that lie between the Reliz Canyon and Vaqueros Formations. If the name "Berry" is not restricted in this way, then conglomerate and red beds of Cretaceous through Miocene age are likely to be included in the Berry Formation and the term "Berry" is stripped of most of its stratigraphic significance. For example, certain red beds in the Adelaida quadrangle belong to the unnamed formation of Cretaceous and Paleocene age, and some conglomeratic red beds in the Stockdale Mountain quadrangle belong to Santa Margarita Formation. Red beds and conglomerate commonly are reported overlying the basement complex in wells, but the lithologic character of these strata is generally related to the position of the beds at the base of the sedimentary sequence rather than to the stratigraphic correlation of the beds with the Berry. Any errors introduced by too severe a restriction of the term "Berry" seem less likely to confuse an understanding of the geologic 

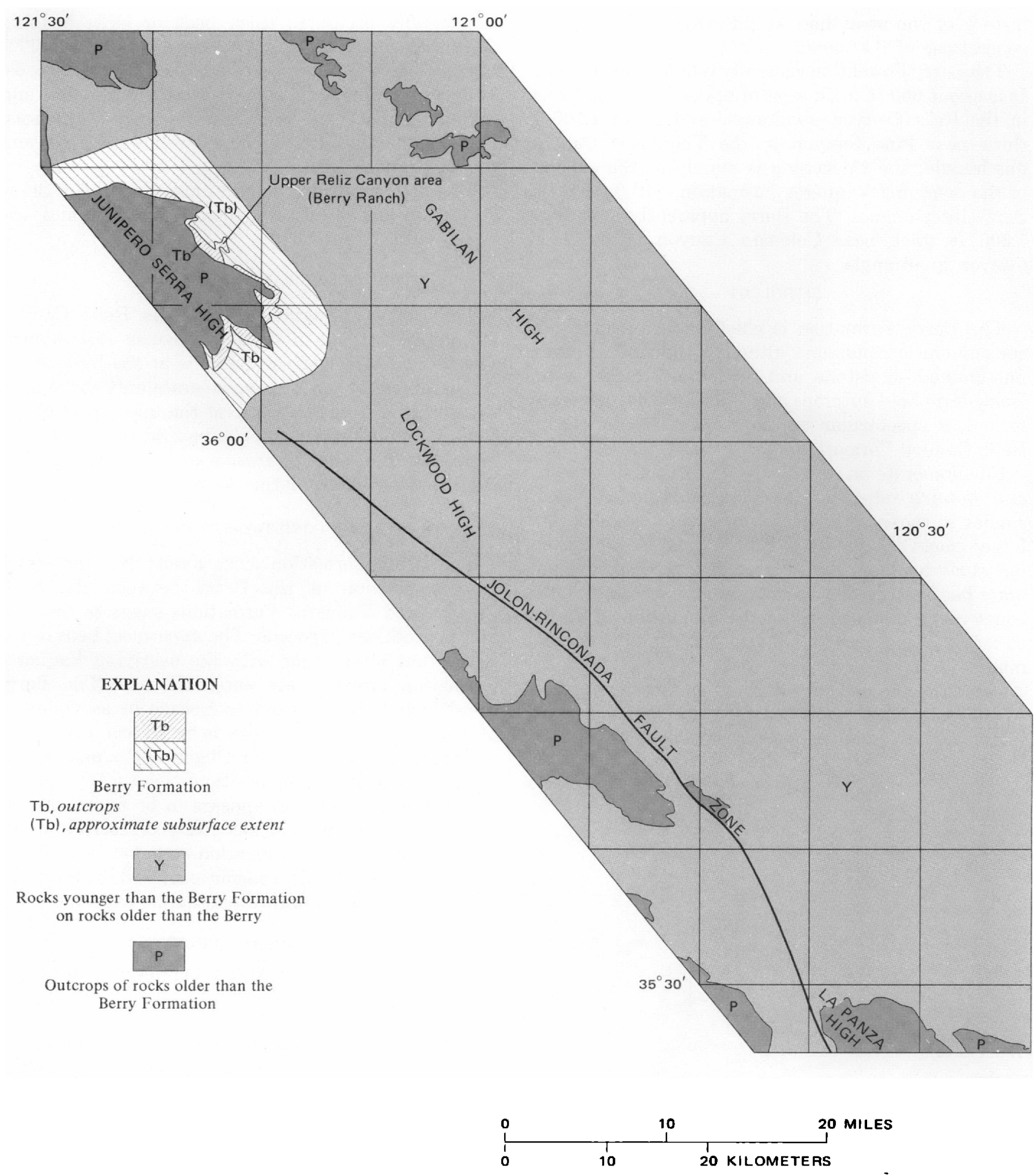

FrguRg 16.-Approximate distribution of the Berry Formation in the southern Salinas Valley area. Small outcrop areas are omitted (quadrangles identified in fig. 2). 
history of the area than would errors caused by too general use of the name.

The Berry Formation generally is $600-1,500 \mathrm{ft}$ thick. It is about $650 \mathrm{ft}$ thick west of upper Vaqueros Creek in the Reliz Canyon quadrangle and about $1,100 \mathrm{ft}$ thick near Pine Canyon in the Thompson Canyon quadrangle; the thickening is mainly at the expense of the overlying Vaqueros Formation, with which the Berry intertongues. The Berry apparently is at least $1,500 \mathrm{ft}$ thick near Coleman Canyon in the Bear Canyon quadrangle.

\section{LITHOLOGY}

The Berry Formation is chiefly conglomerate and conglomeratic sandstone although the unit contains fine-grained sandstone and mudstone. Rocks of the Berry form bold outcrops and cliffs, but they generally form less spectacular outcrops than the underlying Reliz Canyon Formation.

Conglomerate in the Berry Formation is massive and contains well-rounded pebbles and cobbles of rocks similar to those in the nearby basement complex. The larger clasts are chiefly 1-4 in. in greatest dimension, but some boulders are as large as $2 \mathrm{ft}$. The conglomerate has a sandstone matrix and in places grades into conglomeratic sandstone as the proportion of matrix to larger clasts increases. Locally it contains angular mudstone clasts.

Sandstone in the Berry Formation is mainly medium to coarse grained, poorly sorted, and commonly contains scattered granules, pebbles, and cobbles (fig. 17).

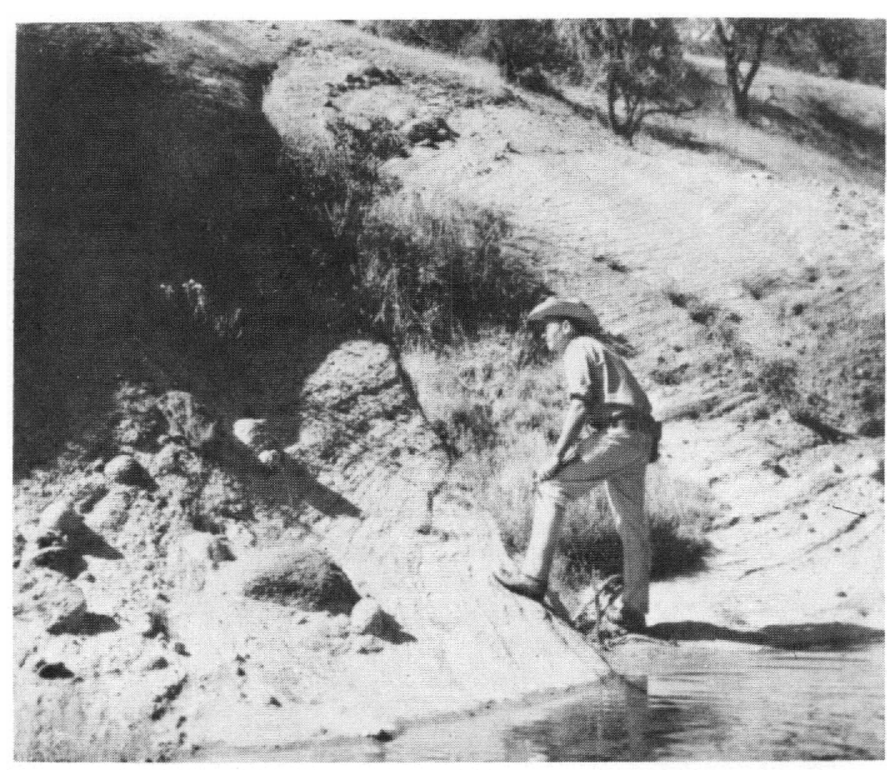

Figure 17.-Cross-stratified conglomeratic sandstone in the Berry Formation, exposed in upper Reliz Canyon, Reliz Canyon quadrangle.
It generally occurs in thick beds or lacks bedding altogether. Some sandstone is cross-stratified (fig. 17). The rock is well indurated and is locally calcareous. The sand grains are subangular to subrounded and are mainly quartz and feldspar in about equal amounts. The weathered rock is chiefly yellowish gray and grayish orange.

Fine-grained sandstone and mudstone in the Berry Formation are massive, generally friable, and are locally reddish brown.

\section{STRATIGRAPHIC RELATIONS}

The Berry Formation overlies the Reliz Canyon Formation without noticeable angular discordance. The lower contact of the Berry is at the base of the stratigraphically lowest conglomerate unit above massive sandstone characteristic of the upper part of the Reliz Canyon Formation. The base of the Berry may represent an episode of erosion or nondeposition during transition from marine to nonmarine conditions.

\section{AGE AND CONDITIONS OF DEPOSITION}

The Berry Formation lacks fossils, but the stratigraphic position of the Berry between the Reliz Canyon and Vaqueros Formations suggests that the unit is probably Oligocene. The uppermost beds of the Berry that intertongue with the overlying Vaqueros Formation probably are early Miocene. The Berry could include beds as old as Eocene or as young as Miocene, but because there is no direct conflicting evidence, it is assigned an Oligocene(?) age on the basis of its stratigraphic position.

The Berry Formation appears to be nonmarine. It lacks marine fossils and has the poor sorting, crude bedding, and cross-stratification common in fluviatile sediments. The local occurrence of red beds in the Berry also gives the unit a nonmarine aspect.

\section{MIOCENE SERIES \\ VAQUEROS FORMATION \\ NOMENCLATURE}

The Vaqueros Formation is the oldest widespread sedimentary-rock unit in the mapped area. Hamlin (1904, p. 14) applied the name "Vaquero Sandstone" to the strata exposed near upper Vaqueros Creek; he included beds that are here assigned to the Vaqueros, Berry, and Reliz Canyon Formations. Thorup (1941) restricted the modified name "Vaqueros Formation" to the upper part of Hamlin's unit.

\section{DISTRIBUTION AND THICKNESS}

The Vaqueros Formation crops out west of the 
Salinas River between the Arroyo Seco and Nacimiento River and extends into the subsurface (fig. 18). It is the basal marine Miocene unit in outcrops from the Arroyo Seco to the Nacimiento River; the younger Tierra Redonda Formation is the basal Miocene unit in outcrops north of the Arroyo Seco and in the southern part of the mapped area. The distribution of the Vaqueros in the subsurface is uncertain in parts of the area because distinguishing the Vaqueros from the Tierra Redonda on lithologic features that are determined from well data is difficult, but the subsurface extent of the Vaqueros can be approximated by considering the relation of the Monterey Formation to the Vaqueros and Tierra Redonda. In the northern part of the mapped area, the Vaqueros is overlain by Monterey beds of the Relizian or Saucesian Stages of Kleinpell (1938), whereas the Tierra Redonda there is overlain by Monterey beds of the Luisian Stage of Kleinpell (1938). Similarly, in the southern part of the area east of the Jolon-Rinconada fault zone, the Vaqueros is overlain by Monterey beds of the Saucesian Stage, whereas the Tierra Redonda there is overlain by Monterey beds of the Luisian or Relizian Stages. West of the Jolon-Rinconada fault zone, the Tierra Redonda Formation overlaps the Vaqueros, which is absent south of the Tierra Redonda Mountain quadrangle.

The Vaqueros Formation generally is $800-2,000 \mathrm{ft}$ thick. It is at least $1,100 \mathrm{ft}$ thick along upper Vaqueros Creek and nearly 2,000 ft thick in upper Reliz Canyon in the Reliz Canyon quadrangle, about $850 \mathrm{ft}$ thick along Pine Canyon in the Thompson Canyon quadrangle, about $1,250 \mathrm{ft}$ thick in the Cosio Knob quadrangle, and about 1,300 $\mathrm{ft}$ thick on Tierra Redonda Mountain in the Tierra Redonda Mountain quadrangle. The subsurface thickness of the Vaqueros (fig. 18) appears to be greater than $3,000 \mathrm{ft}$ in the San Miguel and Ranchito Canyon quadrangles.

\section{LITHOLOGY}

The Vaqueros Formation is chiefly and characteristically sandstone, but it also contains mudstone and conglomerate. The sandstone forms cliffs and large bare-rock exposures (fig. 19); weathering produces cavernous features that range in size from potholes to caves large enough to have been used as shelters by Indians.

Sandstone in the Vaqueros Formation is fine to coarse grained, commonly poorly sorted, and pebbly at some places. It generally is poorly bedded, or lacks bedding altogether, but some fine-grained sandstone is thin bedded or laminated. Calcite commonly cements the rock, and calcite matrix forms as much as 40 percent of some beds. The sandstone is friable to well indurated. The sand grains are subangular to subrounded and are chiefly quartz and feldspar in about equal amounts; scattered granules and pebbles are mainly granitic or volcanic rock. Weathered sandstone is yellowish gray, grayish orange, pale yellowish orange, dark yellowish orange, and very light gray.

Mudstone in the Vaqueros Formation is massive and has a hackly fracture; it generally is dense, well indurated, and calcareous, although some is noncalcareous. The rock commonly has a fetid odor when freshly broken. Weathered mudstone is chiefly pale yellowish brown, yellowish gray, and pale olive.

\section{STRATIGRAPHIC RELATIONS}

The Vaqueros Formation conformably overlies and intertongues with the Berry Formation in the northwestern part of the mapped area, and unconformably overlies the unnamed formation of Cretaceous and Paleocene age between the San Antonio and Nacimiento Rivers. The lower contact of the Vaqueros where the formation overlies the Berry is at the base of the stratigraphically lowest fossilferous beds above unfossiliferous sandstone and conglomerate beds of the Berry; the principal lithologic distinctions between the Vaqueros and Berry are the presence of fossils and the general scarcity of conglomerate in the Vaqueros. The lower contact of the Vaqueros where the formation overlies the unnamed formation is at the base of the stratigraphically lowest fossiliferous beds that unconformably overlie rocks typical of the unnamed formation. The chief lithologic distinctions between the Vaqueros and the unnamed formation are the abundance of fossils, the scarcity of biotite, and the scarcity of clasts larger than pebbles in the Vaqueros. The Vaqueros lies on the basement complex at many places in the subsurface (fig. 9).

\section{FOSSILS}

Fossils are abundant in some beds of the Vaqueros Formation and absent from others, but fossiliferous beds occur throughout the formation. Sandy beds contain fossil mollusks and echinoids, sand-filled tubes, bones, and woody material; mudstone beds contain fossil foraminifers, mollusks, and fish scales. Loel and Corey (1932, p. 117-120) listed about 65 species from localities in the Reliz Canyon, Bear Canyon, Bryson, and Tierra Redonda Mountain quadrangles. Fossils from three localities (fig. 18) are listed below; W. $O$. Addicott identified the fossils and determined that the age and correlation of the faunas is Miocene, "Vaqueros Stage" of Weaver and others (1944). 


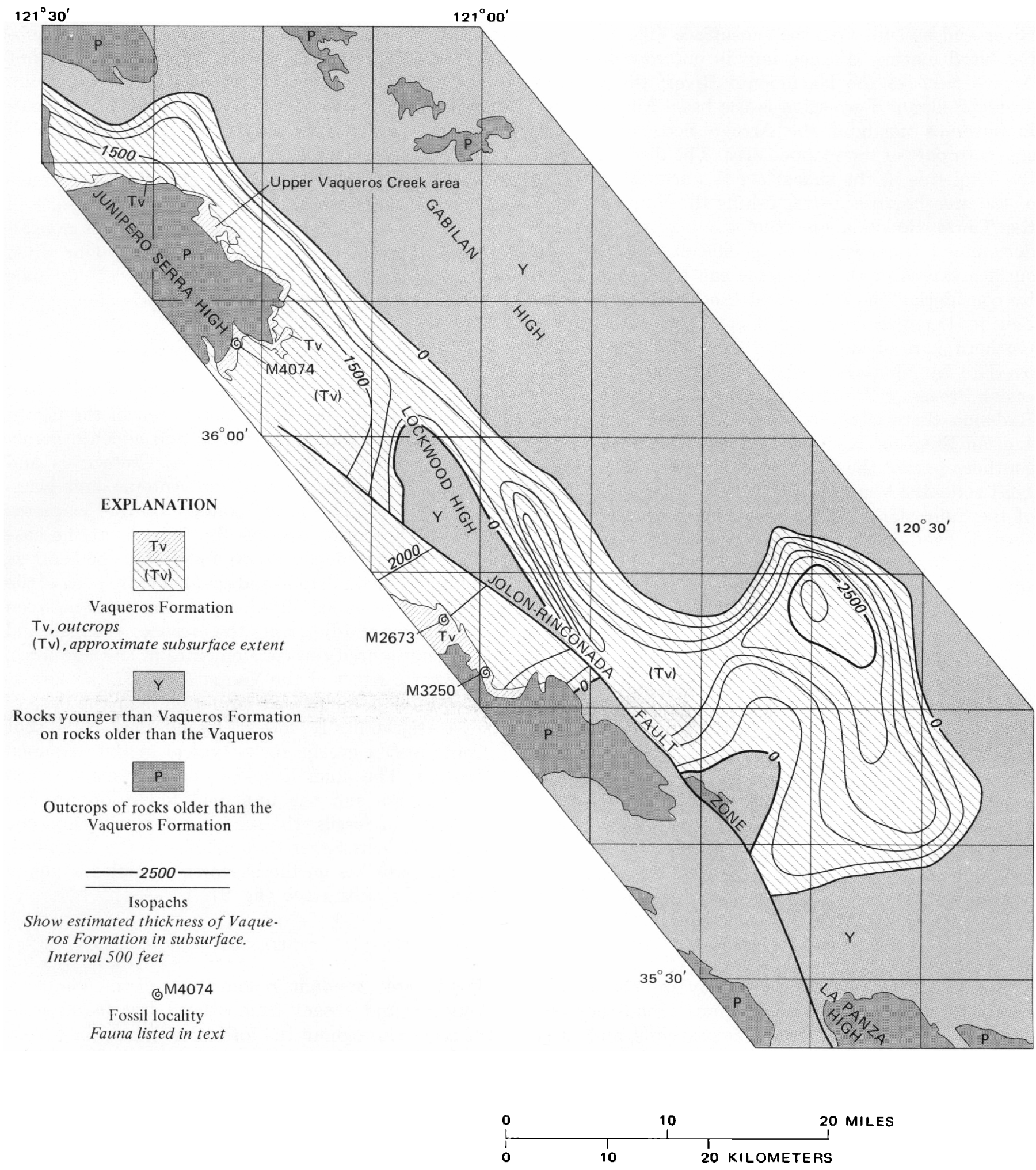

FIGURE 18.-Approximate distribution of the Vaqueros Formation in the southern Salinas Valley area. Small outcrop areas are omitted (quadrangles identified in fig. 2). 


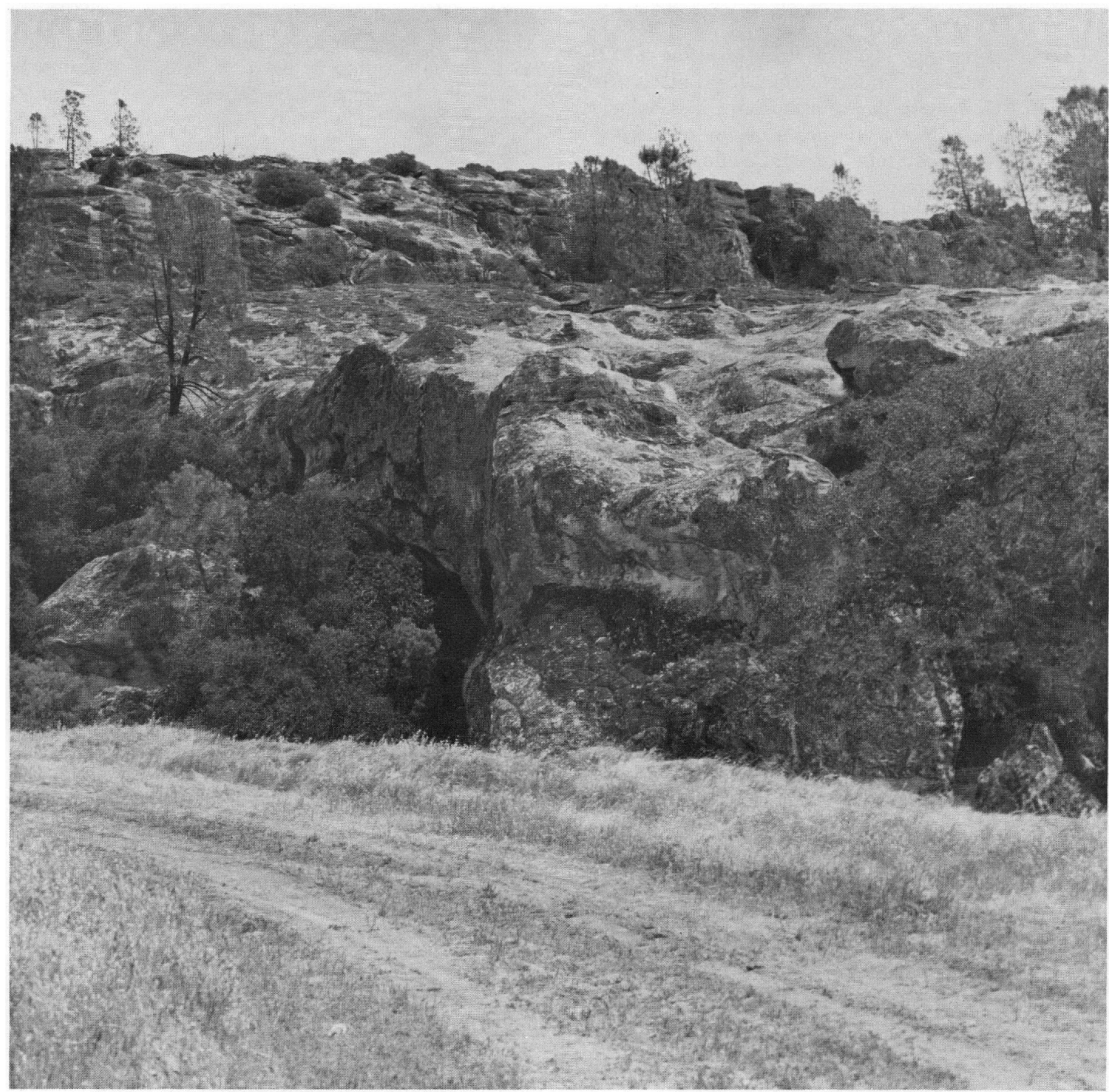

FIGURE 19.-Massive cavernous sandstone in the Vaqueros Formation in the Cosio Knob quadrangle.

USGS loc.

M2673. Bryson quadrangle.

Pelecypods:

Macrochlamis magnolia (Conrad) Vertipecten cf. V. nevadanus (Conrad)

M3250. Tierra Redonda Mountain quadrangle. Gastropod:

Turritella inezana pervulgata Merriam Pelecypods:

Anomia vaquerosensis Loel and Corey Lyropecten miguelensis Loel and Corey?
M4074. Bear Canyon quadrangle.

Echinoid:

Kewia fairbanksi (Arnold)?

Gastropod:

Turritella inezana Conrad

Pelecypods:

Clementia?

Crassostrea vaquerosensis (Loel and Corey)

Crenomytilus loeli (Grant)

Macrochlamis magnolia (Conrad)

Trachycardium vaquerosensis (Arnold) 


\section{AGE AND CONDITIONS OF DEPOSITION}

Fossils and the stratigraphic position of the Vaqueros Formation indicate that the unit is early Miocene. Fossil molluscan faunas from U.S. Geological Survey localities in the Vaqueros belong to the lower Miocene "Vaqueros Stage" of the Pacific Coast megainvertebrate sequence (Weaver and others, 1944) (W. O. Addicott, written communs., 1966-69). The upper part of the Vaqueros in Reliz Canyon contains foraminifers of the Miocene Saucesian Stage (Kleinpell, 1938, fig. 4; Bandy and others, 1969, p. 468); the formation correlates with the Zemorrian and lower Saucesian Stages in the foraminiferal sequence (Kleinpell and others, 1967, p. 39). The stratigraphic position of the Vaqueros below the Tierra Redonda Formation and the Sandholdt Member of the Monterey Formation limits the age of the Vaqueros.

Fossils in the Vaqueros Formation demonstrate the marine origin of most of the unit. The molluscan faunas listed from U.S. Geological Survey localities and those listed by Loel and Corey (1932, p. 117-120) are indicative of a very shallow water depositional environment - generally less than 10-15 fathoms. Included in the fauna are many molluscan genera suggestive of warm-water conditions; genera such as Anadara, Clementia, Dosinia, Lyropecten, Miltha, Ficus, Solenosteira, and Turritella (Torcula) are in modern seas restricted to tropical and subtropical molluscan provinces along the Pacific Coast of North America (Addicott, 1970, p. D6). The foraminiferal fauna from the upper part of the Vaqueros in Reliz Canyon listed by Kleinpell (1938, table 1$)$ indicates middle to lower bathyal depths (R. L. Pierce, oral commun., 1971). The transition from shallow-water marine conditions indicated by the molluscan faunal assemblage in the upper few hundred feet of the Vaqueros in Reliz Canyon (Thorup, 1943) to bathyal depth conditions indicated by the foraminiferal assemblage near the top of the formation there records abrupt deepening of the sea during deposition of lower Saucesian Stage beds.

\section{TIERRA REDONDA FORMATION}

\section{NOMENCLATURE}

The Tierra Redonda Formation contains sandy beds that are stratigraphically equivalent to finer grained rocks in the Sandholdt Member of the Monterey Formation (Durham, 1970, p. 7). It bears the same relation to the Sandholdt Member as the Santa Margarita Formation does to the Hames Member of the Monterey (fig. 10). The type area of the Tierra Redonda Formation is at and north of Tierra Redonda Mountain (fig. 22) and includes its type locality in sec. 10, T. 25 S., R. 9 E. (Durham, 1968a, p. 11). Beds assigned to the Tierra Redonda differ in lithologic detail and stratigraphic position from the Vaqueros Formation, to which they generally were assigned (Schenck and Childs, 1942; Taliaferro, 1943b; Bramlette and Daviess, 1944). Other names applied to parts of the Tierra Redonda include "Temblor Group" (Anderson and Martin, 1914), "Temblor sandstone" (Nickell, 1931), "Monterey sandstone" (Schombel, 1943), and "Vaqueros-Temblor sandstone" (Fiedler, 1944).

\section{DISTRIBUTION AND THICKNESS}

The Tierra Redonda Formation crops out north of the Arroyo Seco and south of the San Antonio and Estrella Rivers; it generally occurs on and around high places on the surface of unconformably underlying rocks where conditions were favorable for accumulation of sand instead of the finer grained sediments that formed the Sandholdt Member of the Monterey Formation (fig. 22).

The Tierra Redonda Formation is thickest at the type area near Tierra Redonda Mountain where it is about $1,650 \mathrm{ft}$ thick; it is $1,400 \mathrm{ft}$ thick in the Wilson Corner quadrangle, $625 \mathrm{ft}$ thick in the Adelaida quadrangle, about $500 \mathrm{ft}$ thick in the Sycamore Flat quadrangle, 400-500 $\mathrm{ft}$ thick in the York Mountain quadrangle, and 50-100 ft thick in the Santa Margarita quadrangle. The intertonguing of beds of the Tierra Redonda and Monterey Formations causes abrupt changes in thickness of the Tierra Redonda; this is well illustrated near the Arroyo Seco where the Tierra Redonda pinches out southward and is absent in Reliz Canyon.

\section{LITHOLOGY}

The Tierra Redonda Formation is mainly and characteristically sandstone, but locally contains conglomerate. The formation commonly stands in cliffs and bold outcrops (fig. 20) although at some places it underlies areas of low relief.

Sandstone in the Tierra Redonda Formation is fine to coarse grained and poorly to well sorted. The rock most commonly is in beds several feet thick or lacks bedding altogether. The sandstone is locally cemented by calcite. Calcareous sandstone generally is well indurated (fig. 20), and noncalcareous rock commonly is friable although some noncalcareous sandstone is well cemented with silica. The sand grains are mainly angular or subangular and are chiefly quartz and feldspar in about equal amounts. The sandstone generally is micaceous and includes abundant basement-rock fragments locally. Weathered sandstone generally is yellowish gray, light gray, and white.

Conglomerate in the Tierra Redonda Formation is 


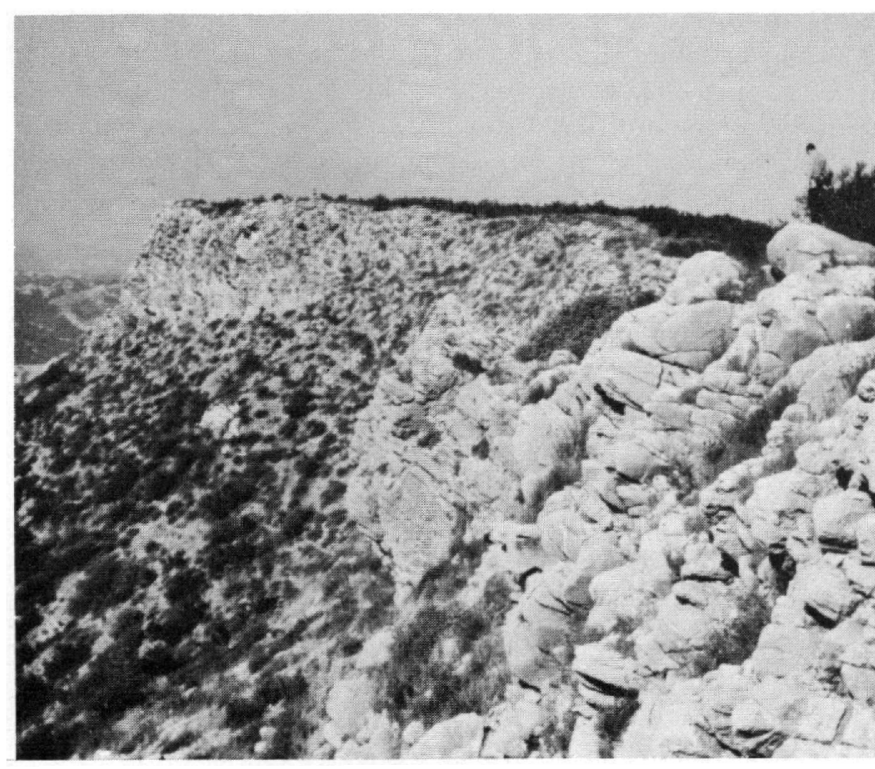

Figure 20.-Calcareous white sandstone in the Tierra Redonda Formation along the crest of Tierra Redonda Mountain. The rock is well indurated.

massive and contains pebbles, cobbles, and boulders as large as $6-8 \mathrm{ft}$ (fig. 21). The larger clasts range from angular to well rounded and are mainly granitic rock although pebbles and cobbles of volcanic porphyry are common in some beds. Angular clasts are abundant near the base of the Tierra Redonda at some places where the formation lies on the basement complex; clasts apparently derived from the unnamed formation

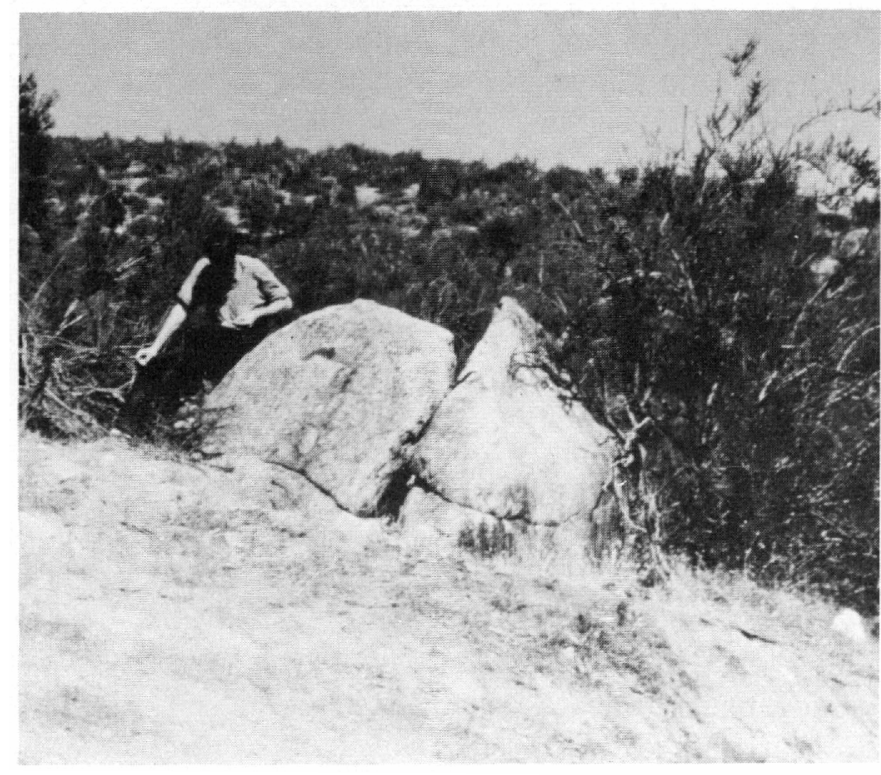

FIGURE 21.-Boulder of granitic rock from the Tierra Redonda Formation north of Harris Creek, Tierra Redonda Mountain quadrangle. The boulder apparently fractured along joints during weathering. of Cretaceous and Paleocene age occur near the base of the Tierra Redonda locally where the unit lies on the unnamed formation.

\section{STRATIGRAPHIC RELATIONS}

Where the Tierra Redonda Formation is exposed, it conformably overlies the Vaqueros Formation north of the Nacimiento River, unconformably overlies the unnamed formation of Cretaceous and Paleocene age south of the Nacimiento River, and unconformably overlies basement complex near the Sierra de Salinas and La Panza Range. The contact between the Tierra Redonda and Vaqueros Formations at the type area of the Tierra Redonda on Tierra Redonda Mountain is at the base of an unfossiliferous unit of massive friable white medium- to coarse-grained conglomeratic sandstone about $50 \mathrm{ft}$ thick that overlies fossiliferous well-cemented grayish-orange fine-grained sandstone of the Vaqueros. The distinction of the Tierra Redonda from the Vaqueros there is based mainly on the absence from the Tierra Redonda of richly fossiliferous hackly fine-grained sandstone and mudstone typical of the Vaqueros. Color, too, is a conspicuous distinction between the two units; sandstone in the Tierra Redonda commonly is white or light gray, in contrast to darker sandstone in the Vaqueros. Conglomerate in the Tierra Redonda helps locally to separate the unit from the Vaqueros. The distinction of the Tierra Redonda from the unnamed formation generally is obvious, because the light-gray and white sandstone in the Tierra Redonda contrasts markedly with darker rocks in the older unit. The lower part of the Tierra Redonda at the north end of the La Panza Range consists of granitic-rock rubble that appears little removed from the source. In both the La Panza Range and the Sierra de Salinas, the Tierra Redonda lies on basement complex as in the subsurface along the flanks of high places on the basement-complex surface (fig. 9).

FossILS

Fossils are scarce at most places in the Tierra Redonda Formation, including the type area, but they are common locally, especially near the La Panza Range. Loel and Corey (1932, p. 167-174) listed more than 160 species of marine invertebrates, mostly mollusks, from beds at the north end of the La Panza Range that are here assigned to the Tierra Redonda; their work was based partly on earlier work by Anderson and Martin (1914). Fossil mollusks from five localities (fig. 22) are listed below; W. O. Addicott identified the fossils and determined the age and correlation of the faunas. 
USGS loc.

M3248. Sycamore Flat quadrangle. Age and correlation: Miocene, "Temblor Stage" of Weaver and others (1944).

Pelecypod:

Leptopecten andersoni (Arnold)

M3813. Wilson Corner quadrangle. Age and correlation: Miocene, "Temblor Stage" of Weaver and others (1944).

Gastropods:

Acteon? sp.

Antillophos posunculensis (Anderson and Martin)

Bruclarkia barkeriana (Cooper)

Cancellaria dalliana Anderson

Conus sp.

Crepidula princeps Conrad

Cylichna temblorensis Keen

Nassarius sp.

Neverita andersoni (Clark)

Olivella cf. $O$. ischnon Keen

Trophon kernensis Anderson?

Turricula sp. aff. T. piercei (Arnold)

Turritella ocoyana Conrad

Pelecypods:

Leptopecten andersoni (Arnold)

Dosinia cf. D. merriami Clark

Macoma astori Dall? cf. M. arctata (Conrad)

Nuculana sp.

Panopea sp.

Solecurtus gabbianus (Anderson and Martin)

Solen curtus Conrad

Spisula cf. S. catilliformis (Conrad)

Tellina cf. T. insurana Hanna wilsoni Anderson and Martin?

Yoldia temblorensis Anderson and Martin

M3814. Wilson Corner quadrangle. Age and correlation: Miocene, "Temblor Stage" of Weaver and others (1944).

Gastropods:

Antillophos posunculensis (Anderson and Martin)

Bruclarkia barkeriana (Cooper)

Calyptraea sp.

Conus sp.

Crepidula princeps Conrad

Ficus? sp.

Hastula gnomon Keen

Nassarius sp.

Neverita cf. $N$. alta Arnold cf. $N$. andersoni (Clark)

Turricula n. sp.

Turritella cf. T. temblorensis Wiedey ocoyana Conrad

Pelecypods:

Anadara sp.

Chione temblorensis (Anderson)

Nuculana sp.

Pectinid

Solecurtus gabbianus (Anderson and Martin)

Spisula cf. S. albaria (Conrad)

aff. S. hamphilli (Dall)
USGS loc.

M3814. Brachiopod:

Discinisca? sp.

M4192. Templeton quadrangle. Age and correlation: Miocene, "Vaqueros" or "Temblor Stage" of Weaver and others (1944).

Pelecypods:

Leptopecten andersoni (Arnold)?

Amussiopecten cf. A. vanvlecki (Arnold)

Chlamys cf. C. hertleini (Loel and Corey)

Brachiopod: Terebratalia sp.

Echinoid: Eucidaris sp.

Barnacle: Balanus sp.

M4199. Lime Mountain Quadrangle. Age and correlation: Miocene, "Vaqueros" or "Temblor Stage" of Weaver and others (1944).

Pelecypods:

Amussiopecten vanvlecki (Arnold)

Cardiid

Chlamys sp.

Glycymeris?

Lyropecten crassicardo (Conrad)

Gastropod:

Astraea?

Orbitoid foraminifer:

Lepidocyclina?

\section{AGE AND CONDITIONS OF DEPOSITION}

Fossils and the stratigraphic position of the Tierra Redonda Formation indicate that the unit is Miocene. According to W. O. Addicott (written communs., 1967, 1968, 1970), faunas at localities M3248, M3813, and M3814 represent the middle Miocene "Temblor Stage" of the Pacific Coast megainvertebrate sequence (Weaver and others, 1944), and the faunas at localities M3247, M3705, M3708, M3949, M4187, M4192, M4199, M4200 contain species indicative of either the Miocene "Vaqueros Stage" or "Temblor Stage" of the Pacific Coast megainvertebrate sequence. Leptopecten andersoni of locality M3248 is restricted elsewhere to strata of the "Temblor Stage" (W. O. Addicott, written commun., 1967). The Tierra Redonda is here assigned to the middle Miocene "Temblor Stage" on the basis of its molluscan assemblage; nowhere in the formation have species been found that elsewhere are restricted to the lower Miocene "Vaqueros Stage" of the Pacific Coast megainvertebrate sequence.

Foraminifers at locality Mf1015 near the base of the Tierra Redonda Formation in the Sycamore Flat quadrangle indicate the middle Miocene lower(?) Luisian Stage (Patsy B. Smith, written commun., 1968). Farther south along the San Antonio River, the Tierra Redonda intertongues with the Sandholdt Member of the Monterey Formation, and there the Tierra Redonda contains foraminifers of the Luisian 
Stage; still farther south, the Tierra Redonda underlies beds that contain foraminifers of the Miocene Relizian and Saucesian Stages. Thus the Tierra Redonda represents parts of the Miocene Saucesian, Relizian, and Luisian Stages of Kleinpell's (1938) foraminiferal sequence.

Fossils in the Tierra Redonda Formation demonstrate that the unit is at least partly marine. According to W. O. Addicott (written commun., 1968) fossil mollusks from the Tierra Redonda north of the Arroyo Seco "represent a shallow-water nearshore environment. Genera such as Miltha, Lyropecten, and Dosinia suggest a warm-water temperature regime comparable to that of the Gulf of California and southwestern coast of Baja California." Addicott (written commun., 1968) interpreted the molluscan assemblages from localities M3813 and M3814 at the north edge of the La Panza Range as representing the upper part of the inner sublittoral zone, 5-20 fathoms. Bathymetry indicated by the molluscan assemblage contrasts with meager evidence from foraminifers. The foraminiferal fauna at locality Mf1015 near the base of the Tierra Redonda in the Sycamore Flat quadrangle suggests bathyal depth (Patsy B. Smith, written commun., 1968), but it came from only a few feet stratigraphically below locality M3706, which contains a shallow-water molluscan assemblage.

At the north end of the mapped area in the Sycamore Flat quadrangle, marine fossils occur near the base as well as higher in the Tierra Redonda Formation; these facts suggest that there the unit is entirely marine. At the south end of the mapped area in the Wilson Corner quadrangle, the lower part of the formation has some nonmarine characteristics, such as absence of fossils, poor sorting, and red beds.

\section{MONTEREY FORMATION}

\section{NOMENCLATURE}

The Monterey Formation is the most widespread and conspicuous marine unit in the mapped area. The name of the formation stems from outcrops near the town of Monterey (fig. 1) that William P. Blake visited in 1854 and later described (Blake, 1855, $1856,1857)$. Blake's descriptions preceded by many years the practice in California of applying names to rock-stratigraphic units, but Blake used the term "Monterey formation" informally (Blake, 1855, p. 331 ) and generally receives credit for naming the unit.

Antisell $(1856$, p. 44$)$, in the first published description of rocks of the Monterey Formation in the mapped area, mentioned "agatic or flinty layers" beneath fossiliferous sandstone near the south end of the Salinas Valley. Whitney (1865) used the name "bitu- minous slates" for rocks in the Monterey and referred to the formation as the "bituminous slate series" ( $p$. 144). Fairbanks (1895, p. 431) also used the term "Bituminous Slate series"; later (Fairbanks, 1898, p. 562 ) he described "bituminous shales and flints" that form the "uppermost member of the Monterey series" in the Salinas Valley; finally he (Fairbanks, 1904a, p. 4) employed the term "Monterey shale." English (1918, p. 228) abandoned the name "Monterey shale" because the term "Monterey" had been adopted as a group name; he proposed instead the designation "Salinas shale" for the "diatomaceous shale which is well developed on the west side of the Salinas Valley." This name failed to win lasting favor and eventually yielded to the terms "Monterey shale" (Bramlette and Daviess, 1944) and "Monterey formation" (Bramlette, 1946). Because so much of the rock in the Monterey is unlaminated or lacks fissility, the name "Monterey Shale" is here abandoned for the southern Salinas Valley area in favor of the term "Monterey Formation."

\section{Members}

The Monterey Formation in the mapped area has three members: the Sandholdt in the lower part, the Hames above, and the Buttle locally at the top. At most places, only two members occur, and in parts of the area, only one. All three members occur near Hames Valley, where the Hames and Buttle Members crop out. All three members crop out near Copperhead Creek (fig. 38), but faulting abbreviates the formation there.

Sandholdt Member. - The Sandholdt Member of the Monterey Formation is mainly calcareous mudstone and shale, which together with associated chert, porcelanite, sandstone and dolomite make up the lower part of the formation at most places in the mapped area (Durham, 1963, p. Q15). Thorup (1941) used the name "Sandholdt Formation" for a unit of clay shale and interbedded sandstone above the Vaqueros Formation in Reliz Canyon; he designated as the top of his formation the base of the "lowermost-occurring cherts and porcellaneous shales" of the overlying Monterey (Thorup, 1943, p. 466). The top of the Sandholdt Member, as the term was redefined by Durham (1963) and is used here, is at the top of the stratigraphically highest calcareous mudstone beds in the Monterey; this places the top higher than the upper boundary that Thorup designated. Definition of the Sandholdt to include all the calcareous mudstone and shale in the Monterey provides a useful and easily recognized upper contact for the member because calcareous rocks occur only in the lower part of the Monterey whereas cherty rocks occur throughout the 
formation; the definition also provides a practical basis for subdividing the Monterey in areas of complex structure or poor exposures. The upper contact of the Sandholdt Member generally is conspicuous on electric logs of wells, where jagged and widely fluctuating spontaneous-potential and resistivity curves typical of siliceous rocks of the Monterey give way downward to relatively featureless high spontaneous-potential and low resistivity curves.

Hames Member.-Siliceous mudstone, porcelaneous rocks, chert, and associated dolomite that form the upper part of the Monterey Formation is here named the Hames Member for its occurrence near Hames Valley, one of the few places where all three members of the Monterey occur in the same stratigraphic sequence. The upper part of the member crops out in the hills around Hames Valley and the lower part is in the subsurface there.

The generally discontinuous exposure and complicated structure of the Hames Member of the Monterey Formation prevent designation of a type section for the entire unit. The upper contact relations and lithologic character of the upper part of the member are well exposed southwest of Hames Valley and along the highway that crosses the hills to the west; this area, from the NW $1 / 4$ sec. 5, T. 24 S., R. 10 E., northwestward through secs. 31 and 30 , T. 23 S., R. 10 E., to secs 25 and 26, T. 23 S., R. 9 E., in the Hames Valley quadrangle, is designated the type locality. The upper part of the Hames Member is also well exposed in Reliz Canyon, where the Buttle Member is absent and the Pancho Rico Formation overlies the Hames (Durham, 1963, measured section 5); this area in the SE $1 / 4$ sec. 35 , and SW $1 / 4$ sec. 36 , T. 19 S., R. 6 E., in the Reliz Canyon quadrangle, is designated a reference locality for the upper part of the Hames Member at those places where it underlies the Pancho Rico. The upper part is also well exposed along the Nacimiento River, where the Buttle Member is absent and the Santa Margarita Formation overlies the Hames; this area in the NW $1 / 4$ sec. 13, T. 25 S., R. 10 E., in the Bradley quadrangle, is designated a reference locality for the upper part of the Hames Member at those places where it underlies the Santa Margarita. The lower part of the Hames Member crops out in Reliz Canyon; the area in and near sec. 14, T. 20 S., R. 6 E., in the Reliz Canyon quadrangle, is designated a reference locality for the lower part of the member.

Following the pioneering work of Fairbanks (1898, 1904a) and Hamlin (1904), geologists assigned porcelaneous rocks west of the Salinas River to the Monterey Formation or Monterey Shale; after the work of English (1918) some geologists assigned them to the Salinas Shale, but English (1918, p. 229-230) and later investigators considered similar beds east of the river a "shale member" of the Santa Margarita Formation. English apparently believed that beds east of the river differ from the Monterey, or his Salinas Shale, because they overlie sandstone of the Santa Margarita locally, whereas generally the Monterey underlies the Santa Margarita. This seemingly abnormal stratigraphic sequence occurs where sandstone tongues of the Santa Margarita project into the Monterey, but porcelaneous rocks above and below the tongues are both lithologically identical with and stratigraphically equivalent to rocks of the Monterey west of the river. Except for the Santa Margarita, the exposed stratigraphic sequence of Hames Member, Buttle Member, and Pancho Rico Formation is the same on the east and west sides of the river, and the name Hames Member is appropriate in both places.

Buttle Member.-The Buttle Member of the Monterey Formation consists of diatomaceous rocks that occur locally near the top of the formation. English (1918) assigned diatomaceous rocks at the top of the Monterey west of the Salinas River to his Salinas Shale, but he assigned similar rocks east of the river to a "shale member" of the Santa Margarita Formation. Mandra $(1960 \mathrm{a} ; 1960 \mathrm{~b}$, p. $79 ; 1963)$ gave the name "Buttle Diatomite" to the diatomaceous rocks west of the river and designated Buttle Canyon in the Bradley quadrangle as the type locality. Diatomaceous rocks in the Monterey on both sides of the river were assigned to an unnamed diatomaceous mudstone member of the Monterey in an earlier report (Durham, 1966, p. 6); later the unit was named the Buttle Member of the Monterey (Durham, 1968a, p. 16-17). The modification of Mandra's term "Buttle Diatomite" to "Buttle Member" avoids the implication that the unit is everywhere as richly diatomaceous as it is at Buttle Canyon.

\section{DISTRIBUTION AND THICKNESS}

The Monterey Formation crops out west of the Salinas River for nearly the entire length of the mapped area and east of the river from Sargent Canyon to Ranchito Canyon and near the La Panza Range. For convenience in showing the distribution of the Monterey Formation and stratigraphically equivalent sandy units, the Sandholdt Member of the Monterey is combined with the Tierra Redonda Formation (fig. 22 ), and the Hames and Buttle Members with the Santa Margarita Formation (fig. 23), as shown on the structure sections (pl. 2).

The thickness of the Monterey Formation varies considerably from place to place; it is as great as $8,000-10,000 \mathrm{ft}$ in the Reliz Canyon and Hames Valley quadrangles. Variation in thickness is due partly to 


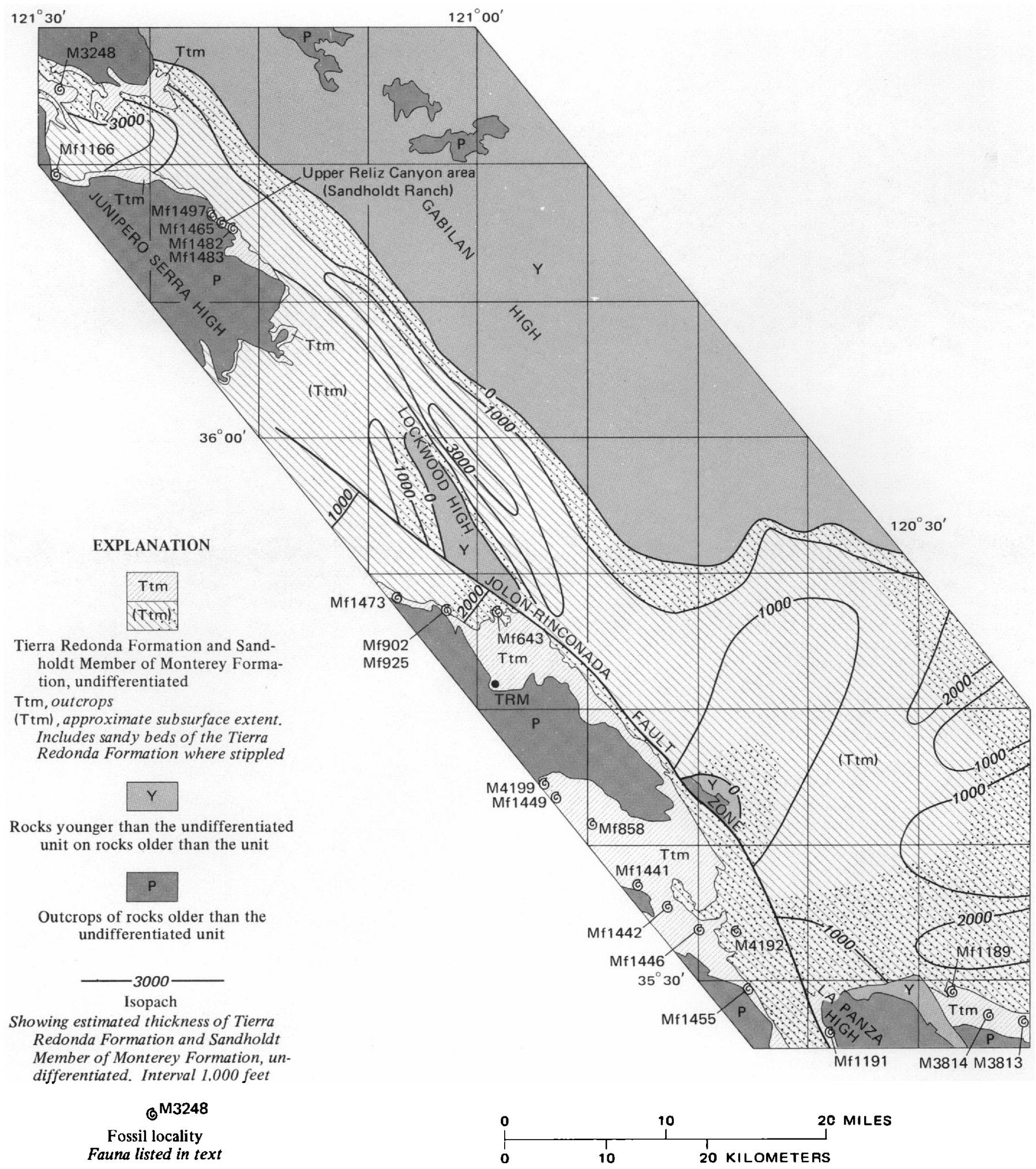

Frgure 22.-Approximate distribution of the Tierra Redonda Formation and the Sandholdt Member of the Monterey Formation, undifferentiated, in the southern Salinas Valley area. Isopachs show estimated thickness of the undifferentiated unit in the subsurface. Small outcrop areas are omitted, including one at fossil locality M4192 (quadrangles identified in fig. 2). TRM, Tierra Redonda Mountain. 


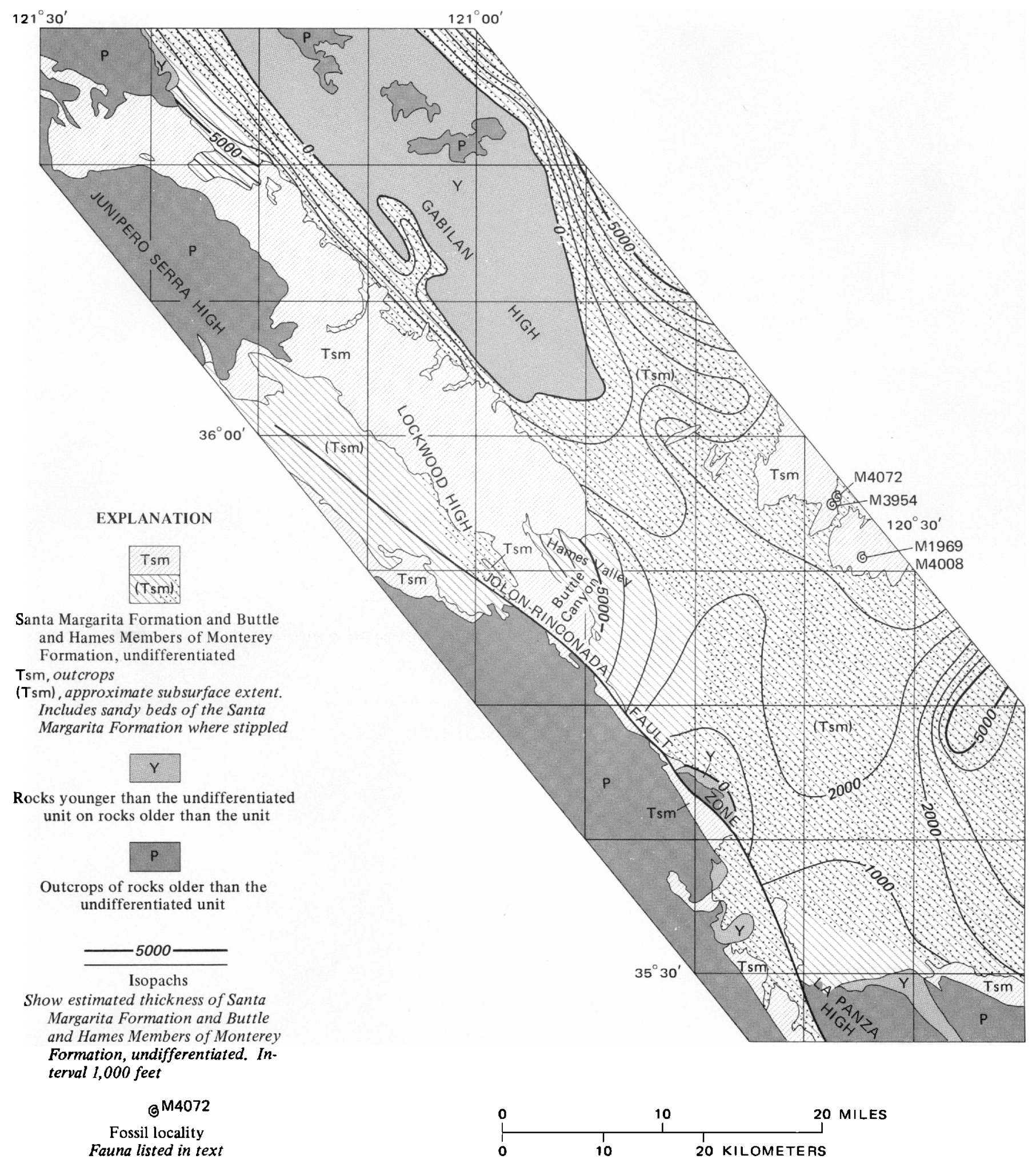

FIGURE 23.-Approximate distribution of the Santa Margarita Formation and the Hames and Buttle Members of the Monterey Formation, undifferentiated, in the southern Salinas Valley area. Isopachs show estimated thickness of the undifferentiated unit in the subsurface. Small outcrop areas are omitted (quadrangles identified in fig. 2). 
lateral change from fine-grained rocks of the Monterey to sandy rocks of the Santa Margarita and Tierra Redonda Formations, and probably is also due partly to areal differences in rate or duration of sedimentation, possibly in response to relief or tectonic changes in relief on the Miocene sea floor. The Sandholdt Member is 2,000-3,000 ft thick near the Arroyo Seco and Hames Valley. In contrast, it is only about $1,200 \mathrm{ft}$ thick in upper Reliz Canyon, about $800 \mathrm{ft}$ thick in the Wilson Corner quadrangle, $600 \mathrm{ft}$ thick in the northwest part of the Cosio Knob quadrangle, $400 \mathrm{ft}$ thick in the northwest part of the Sycamore Flat quadrangle, and 75-100 ft thick in the Bear Canyon quadrangle. The Hames Member is as much as 7,000 $\mathrm{ft}$ thick near the mouth of the Arroyo Seco and in the Hames Valley area, but generally is much less. Thickness estimates for the Hames are uncertain at most places because the unit is incompletely exposed or structurally complicated. The Buttle Member is $600-700 \mathrm{ft}$ thick around Hames Valley and about $350 \mathrm{ft}$ thick west of Indian Valley in the Valleton quadrangle.

\section{LITHOLOGY}

The Monterey Formation consists mainly of rocks that have a high silica content. Calcareous mudstone (fig. 24) characterizes the lower part of the formation and richly diatomaceous rock is common near the top; the remainder of the Monterey is chiefly siliceous mudstone and porcelaneous and cherty rocks. Dolomite beds and concretions are interspersed in the formation and tuff beds occur locally. Sandstone is scarce except near the base of the formation and where the Monterey intertongues with the sandy Santa Margarita and Tierra Redonda Formations.

The Monterey Formation is best exposed along ridges and streams; the unit generally forms rounded hills (fig. 25) with few prominent outcrops other than local cliffs and dip slopes. Vegetation is an unreliable guide to the lithologic character of the Monterey; both grass and dense chaparral grow well on all three members, although the contract between the Sandholdt and Hames Members is marked locally by a change from grass to chaparral.

\section{PorCELANEOUS Rocks}

The term "porcelaneous rocks" describes both porcelanite $^{3}$ and porcelaneous mudstone. Porcelanite is a

\footnotetext{
"The alternate spelling "porcellanite" is preferred by some writers, possibly because the rock name was derived from the Italian word "porcellana" (Tarr. 1938, p. 20) rather than from the English word "porcelain," but most writers who describe the Monterey Formation (for example: Taliaferro, 1934; Bramlette, 1946) seem to prefer the spelling porcelanite. "Chester (1896, p. 216) the name "porcellanite" as a substitute for A. G. Werner's term "porcelainjasper" (German: Porzellanjaspis-used to describe a hard, naturally baked clay) to avoid confusion with genuine jasper. According to Tarr (1938, $p$. 21), the term "hornfels" refers to "a thermally metamorphosed clay or shale and adequately covers the requirements for rocks of that type," leaving "the term 'porcellanite' available for the argillaceous high-silica rocks (such as the Mowry and Monterey) possessing the luster, hardness, and texture of unglazed porcelain."
}

silica-rich rock intermediate in appearance between mudstone and chert. Taliaferro (1934, p. 196) who used the term "porcelanite" for some rocks in the Monterey Formation, stated that the name "is purely descriptive and has been applied to many rock types." The term, as he used it, indicates "simply that the rock has the general appearance and texture of unglazed porcelain." He used the name for "dense compact rocks that, clearly, are neither cherts nor shales" and that "have been referred to by other authors as white shales, siliceous shales, siliceous mudstones, or impure cherts." Bramlette (1946, p. 15) adopted the name "porcelanite" for "designating the silica-cemented rocks that are less hard, dense, and vitreous than chert" and that have "a dull or matte lustre resembling that of unglazed porcelain."

Porcelanite grades into porcelaneous mudstone by an increase in the amount of clay, silt, and sand in the rock. Porcelaneous mudstone grades into ordinary mudstone with further increase in the proportion of clastic material to silica matrix. Toward the other extreme, porcelanite grades into a dense cherty rock, probably by conversion of the porcelanite into cryptocrystalline quartz. Ernst and Calvert (1969, p. 119, 131) suggested a progressive transformation of biogenetic opal in diatomite through cristobalite in porcelanite to cryptocrystalline quartz in chert. At some places, porcelaneous rocks grade laterally within a single bed into mudstone or chert.

Chalcedony and opal form conspicuous veins, bands, and irregular masses in porcelaneous rocks; they commonly recement brecciated porcelaneous rock and form veins that include fragments of the rock. Concentrically banded ellipsoids, like those described at length by Taliaferro (1934), are conspicuous locally. They are generally 2-4 in. in greatest dimension and have alternate concentric shells of porcelaneous and cherty material 0.04-0.2 in. thick.

Porcelaneous rocks range from well bedded (fig. 26) to massive (fig. 27 ) ; beds generally are $1-6$ in. thick and the bedding surfaces ordinarily are planar, although some are irregular. Some porcelaneous rocks that appear laminated lack fissility. The porcelaneous rocks are brittle and give a ringing sound when struck with a pick. They have a hackly or conchoidal fracture habit and break into blocks rarely larger than 2-3 in. in greatest dimension. Fracture surfaces generally are curved and many are marked with arcuate concentric ridges; some blocks have razor-sharp edges.

Porcelaneous rocks commonly contain scattered angular very fine sand grains, chiefly quartz and feldspar; they have coarser sand grains locally where the Monterey and Santa Margarita or Tierra Redonda 


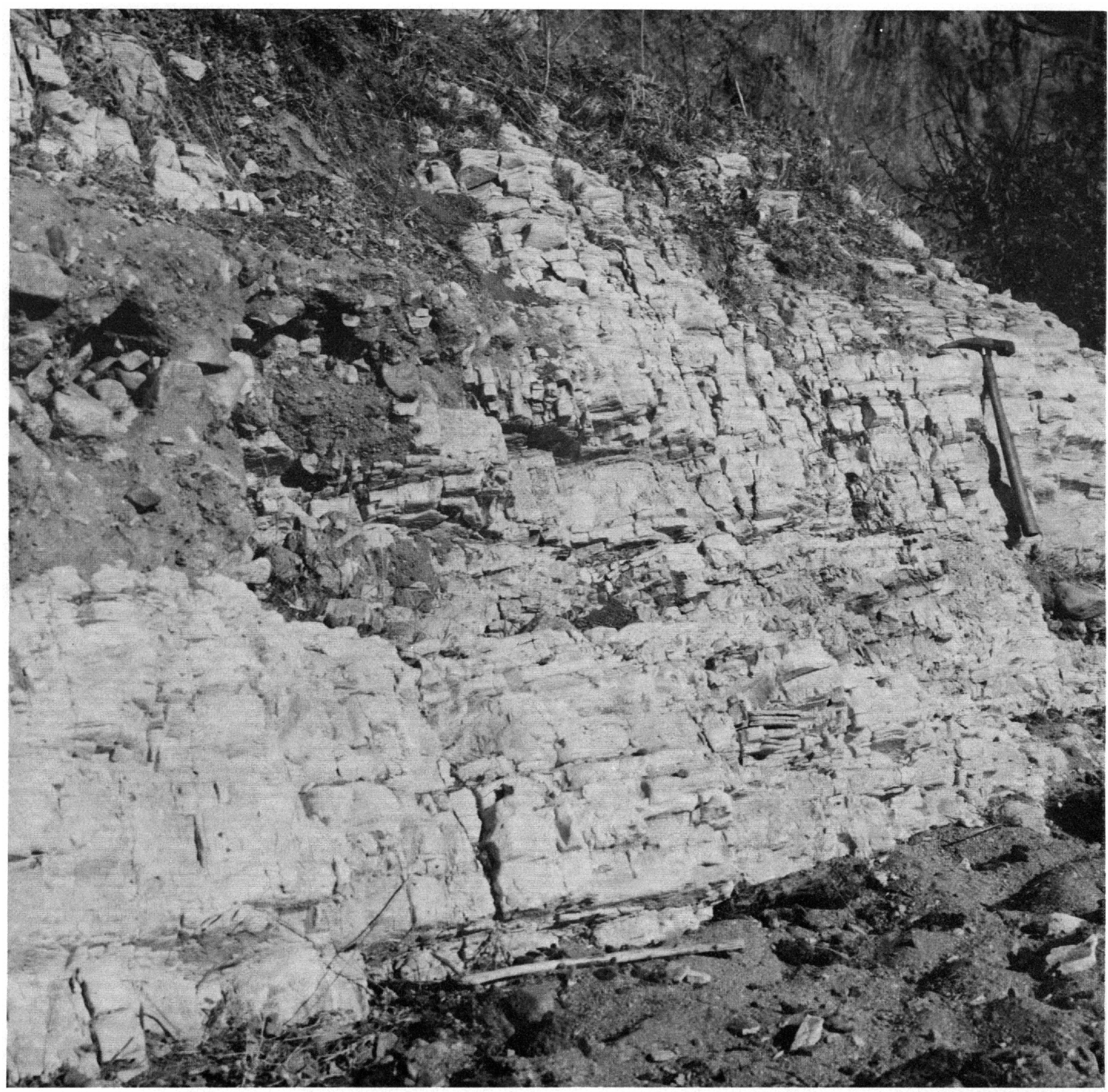

FIGURE 24. - Shaly calcareous mudstone in the Sandholdt Member of the Monterey Formation at fossil locality Mf1487 in upper Reliz Canyon, Reliz Canyon quadrangle. Some of the rock is a coquinoid made up almost entirely of foraminiferal tests; the rock is tar stained locally.

Formations intertongue. Porcelaneous rocks also contain mica flakes, diatom frustules, silicified foraminiferal tests, sponge spicules, and fish scales. Phosphatic pellets and nodules occur in porcelaneous rocks of the Hames Member locally, and thin bentonite beds commonly are intercalated with porcelaneous rocks. Gypsum encrusts many bedding and fracture surfaces. Weathered porcelaneous rocks are mainly very pale orange and pinkish gray, and subordinately yellowish gray, very light gray, pale yellowish brown, light olive gray, and white.

Porcelaneous rocks form most of the Hames Member, are associated with calcareous mudstone and sandstone in the Sandholdt Member, and are interspersed with diatomaceous rocks in beds or units 1-24 in. thick in the Buttle Member. 


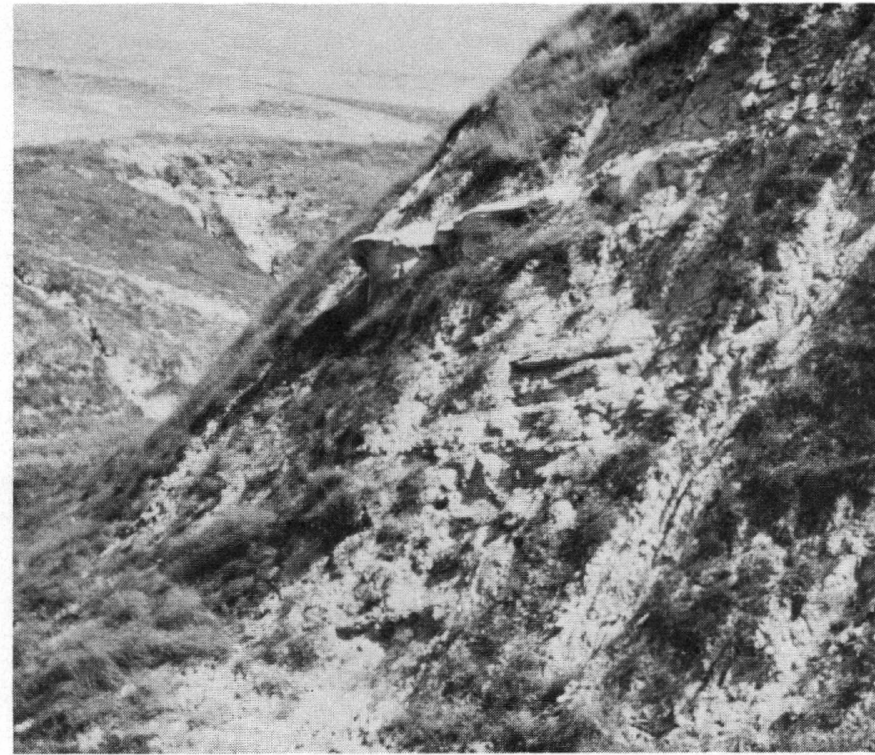

Figure 25.-Calcareous shale in the Sandholdt Member of the Monterey Formation along the gully that Kleinpell (1938, p. 121) designated "the type for the Luisian Stage," Wilson Corner quadrangle. The exposure is about $40 \mathrm{ft}$ high. The rock forms rounded hills and generally crops out poorly.

\section{Mudstone ANd Shale}

The term "mudstone" describes fine-grained clastic rocks that are thick bedded or massive; the term "shale" refers to similar rocks that are thin bedded and fissile. The rocks are composed mainly of silt and clay, but they also contain scattered sand grains, mica flakes, and organic debris. The Monterey Formation contains both siliceous and calcareous mudstone and shale. The siliceous rocks are most common in the Hames Member; the calcareous rocks are restricted to the Sandholdt Member.

Siliceous mudstone grades through diatomaceous mudstone to diatomite, apparently by an increase in the proportion of diatomaceous debris to other clastic material in the rock. Siliceous mudstone in the Monterey is similar to the porcelaneous rocks in appearance but lacks the abundant silica matrix characteristic of porcelanite. It ranges from shaly to massive, and where bedding is obvious, the beds generally are 1-12 in. thick. Weathered siliceous mudstone most commonly is very pale orange, yellowish gray, and pale yellowish brown but it has a wide range of color.

Calcareous mudstone in the Sandholdt Member commonly is soft and punky and generally is laminated or shaly (fig. 24), although some is massive or thick bedded. Foraminiferal tests and fragments are abundant in the rock; according to studies by K. J. Murata (written commun., 1967, cited in Durham, 1968a, p. 21-22), they are the only carbonate in it. At a few places, for example, in the creek bank in Reliz Canyon near the east line of sec 14, T. 20 S., R. 6 E. (fig. 24), the rock is a coquinoid made up almost entirely of foraminiferal tests. Weathered calcareous mudstone most commonly is very pale orange, but it has a wide range of color that includes pale yellowish brown, yellowish gray, and white.

\section{Diatomaceous Rocks}

Diatomaceous rocks in the Monterey Formation contain abundant diatom frustules and fragments intermixed with clay, silt, and other clastic material. The term "diatomite" refers to rock composed mainly of diatom debris, and the term "diatomaceous mudstone" applies to rock that contains conspicuous amounts of clastic material in addition to diatom debris. The diatomaceous rocks are poorly bedded or massive, soft, and porous and have a hackly or conchoidal fracture; they are mainly white. The rocks contain conspicuous discoidal diatom frustules and locally include scattered very fine sand grains, mica flakes, sponge spicules, fish scales, and fish bones. At some places, diatomaceous rocks are interspersed with beds of porcelanite, chert, and dolomite. Diatomaceous rocks in the Monterey occur mainly in the Buttle Member; a notable exception is the diatomite with foraminifers in the Sandholdt Member south of the San Antonio River near fossil localities Mf780 and Mf832 (fig. 39) in the Tierra Redonda Mountain quadrangle.

\section{Chert}

Chert is denser and more vitreous than porcelanite and consists mainly of cryptocrystalline quartz. It generally lacks conspicuous clay, silt, and other clastic impurities. The chert ordinarily is massive or poorly bedded; where it is bedded, the beds commonly are 1-2 in. thick and the bedding surfaces are irregular. Chert also forms lenses and beds that pinch and swell. Ernst and Calvert $(1969$, p. 131) tentatively concluded, on the basis of experimental studies, that chert beds mark channelways along which moderately alkaline aqueous fluids converted porcelanite and diatomite into cryptocrystalline quartz. The chert is hard, brittle, and glasslike. It is interbedded with diatomaceous rocks in the Buttle Member, with porcelaneous rocks in the Hames Member, and with calcareous mudstone and porcelaneous rocks in the Sandholdt Member; chert and porcelanite are intimately mixed in some beds. Chert ranges from olive black and dark reddish brown to white; even dark chert is translucent on thin edges.

\section{DOLOMITE}

Dolomite forms beds and concretions in the Monterey Formation. The beds generally are half a foot to 


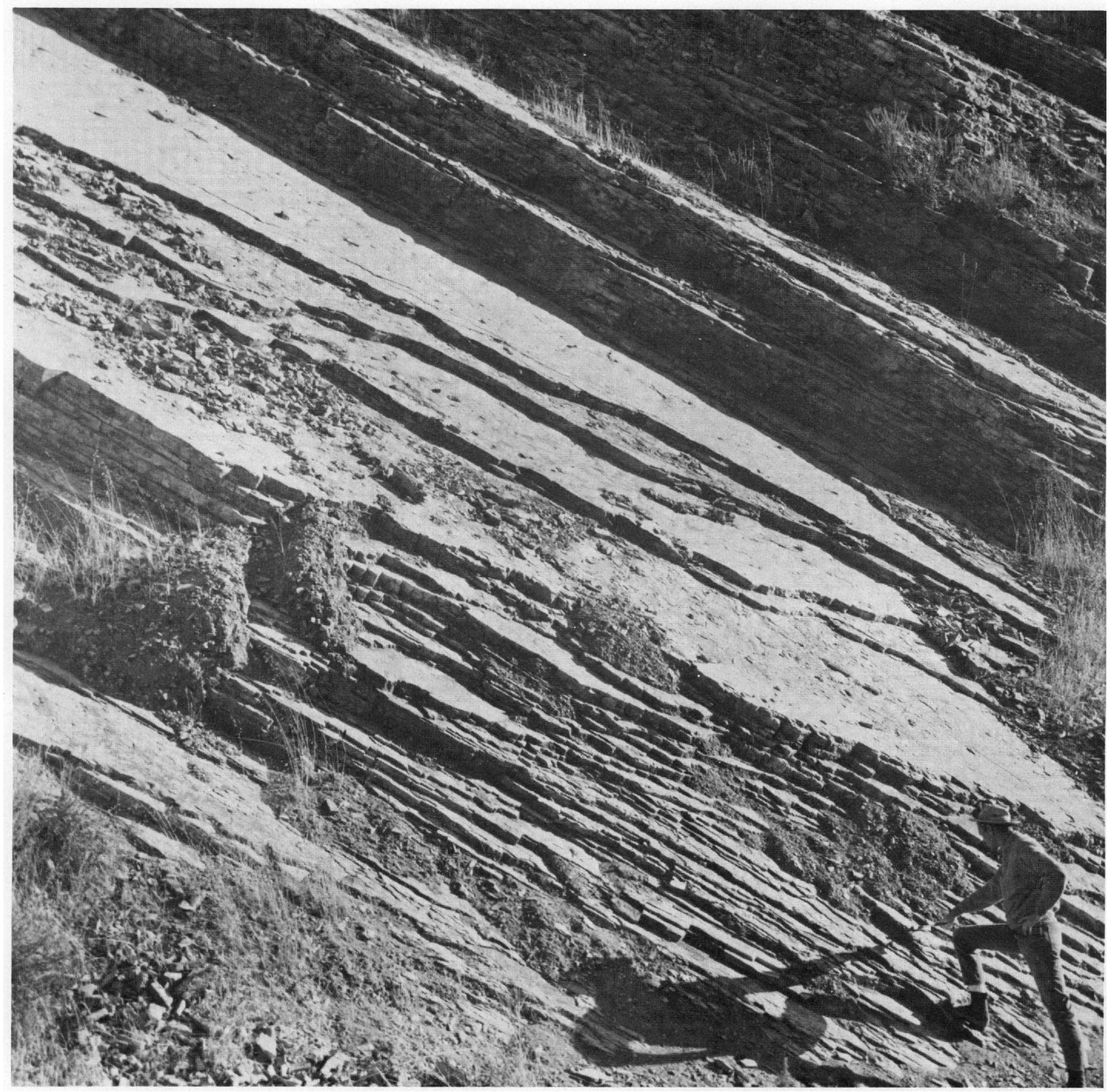

FIGURE 26.-Well-bedded procelaneous rock in the Hames Member of the Monterey Formation exposed near Piney Creek Sycamore Flat quadrangle.

$3 \mathrm{ft}$ thick and are separated by much thicker sequences of mudstone or porcelaneous rock. The concretions, which generally are ellipsoidal (fig. 28), are as thick as $18 \mathrm{in}$. and as long as $8 \mathrm{ft}$. They occur in particular beds, rather than scattered at random, and are oriented with their two longer axes parallel to bedding. The fact that the bedding passes from the surrounding rocks into and through the concretions (fig. 29) indicates that the concretions formed by concentration of carbonate in preexisting sediments or rock. Beds that pass through the concretions are thicker inside the concretions than they are outside, a condition that indicates the concretions formed before complete compaction of the enclosing sediments. Because some concretions are at the same stratigraphic horizon as, but beyond the end of, a dolomite bed, one may conclude that 


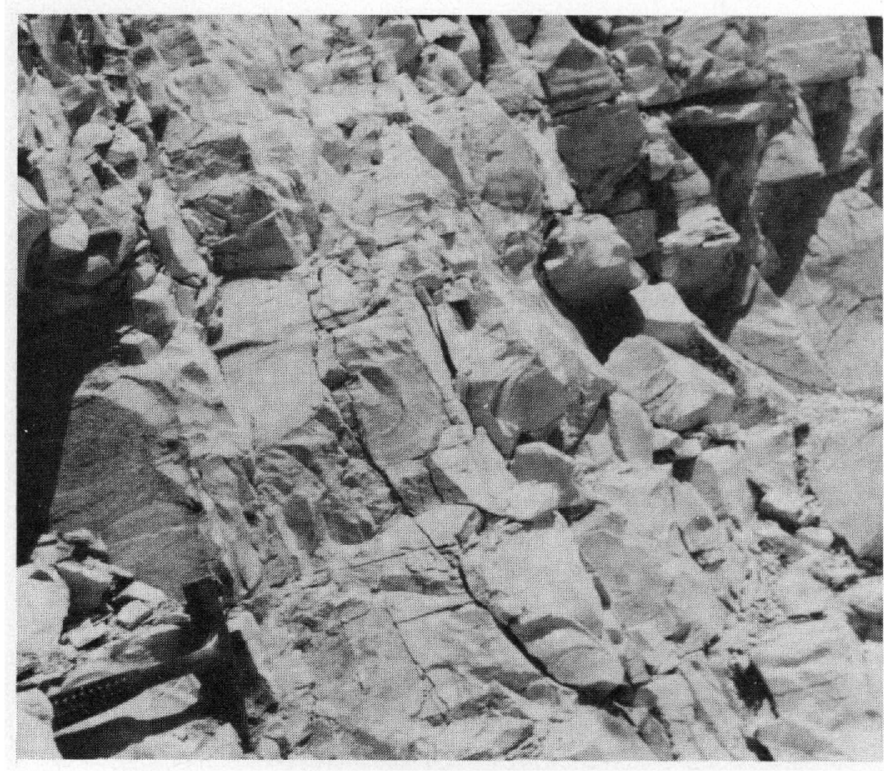

Figure 27.-Massive porcelaneous rock in the Hames Member of the Monterey Formation exposed along a road at the head of Garrissere Canyon, Williams Hill quadrangle. The pick handle is parallel to bedding.

dolomite beds form at particular horizons where concretions are numerous enough and large enough to coalesce.

The dolomite is hard and dense, contains conspicuous veins of calcite, and generally forms bold outcrops. It also contains angular very fine sand, has imprints of fish scales and diatoms, and includes calcite and silica casts of foraminifers and diatoms; these features indicate that the dolomite formed from fine-grained sediments similar to sediments that developed into other rocks of the Monterey. Weathered dolomite is grayish orange, yellowish gray, pale yellowish orange, dark yellowish orange, and pale reddish brown.

\section{SANDSTONE}

Sandstone is scarce in the Monterey Formation, but occurs locally-especially near the base of the Monterey and where the unit intertongues with the Tierra Redonda and Santa Margarita Formations. The rock generally is fine or medium grained and moderately well sorted; weathered sandstone is medium light gray, yellowish gray, pale yellowish brown, grayish orange, and very pale orange. The sand grains range from angular to subrounded and are chiefly quartz and feldspar. Sandstone beds range in thickness from a fraction of an inch to several feet and commonly are grouped into sandstone units several tens of feet thick. Sandstone associated with the Sandholdt Member generally is calcareous, well cemented, and laced with veins of calcite; sandstone associated with the Hames

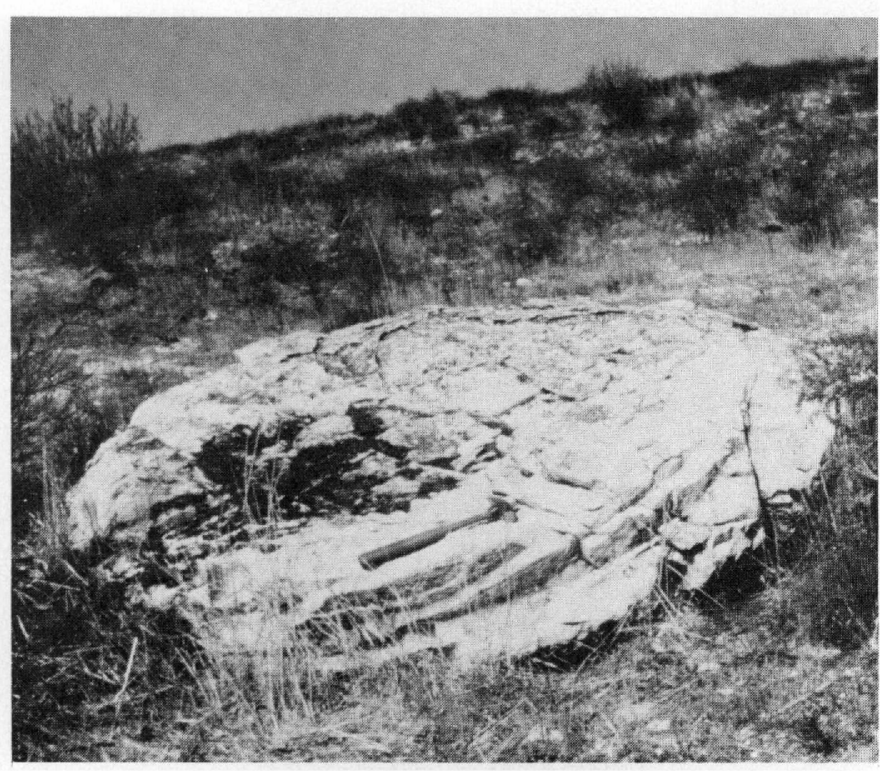

FIGURE 28.-Ellipsoidal dolomite concretion from the Hames Member of the Monterey Formation, Wunpost quadrangle.

Member generally is noncalcareous and friable. Near the top of the Hames Member along the Nacimiento River in the Bradley quadrangle the sandstone is bituminous (fig. 44). Sandstone in the Hames Member near tongues of the Santa Margarita Formation in the Stockdale Mountain quadrangle has a porcelanite matrix.

Sandstone dikes in the Sandholdt Member of the Monterey Formation are well exposed along Harris Creek in the Tierra Redonda Mountain quadrangle and along Graves Creek in the Atascadero quadrangle. They cut across the bedding of mudstone and shale and are deformed with the enclosing rock; these features indicate that the dikes invaded preexisting sediments or rocks before deformation of those strata. Newsome (1903, p. 229-235) described the dikes at Graves Creek, and Bagg (1905, pl. 1) included a photograph of one of the dikes in a paper on foraminifers.

\section{PHOSPHORITE}

Phosphorite commonly is associated with porcelaneous rocks and siliceous mudstone near the base of the Hames Member of the Monterey Formation in beds 1-12 in. thick that consist largely of spherical or ellipsoidal phosphatic pellets $0.05-0.4$ in. in diameter. Some pellets lack internal structure; others have concentric layers around a core of silt and clay or around a sand grain. The concentric structure suggests accretion of phosphatic material around a clastic nucleus. Certain pellet beds contain scattered irregular phosphatic nodules as large as a half inch to 1 in. in greatest 


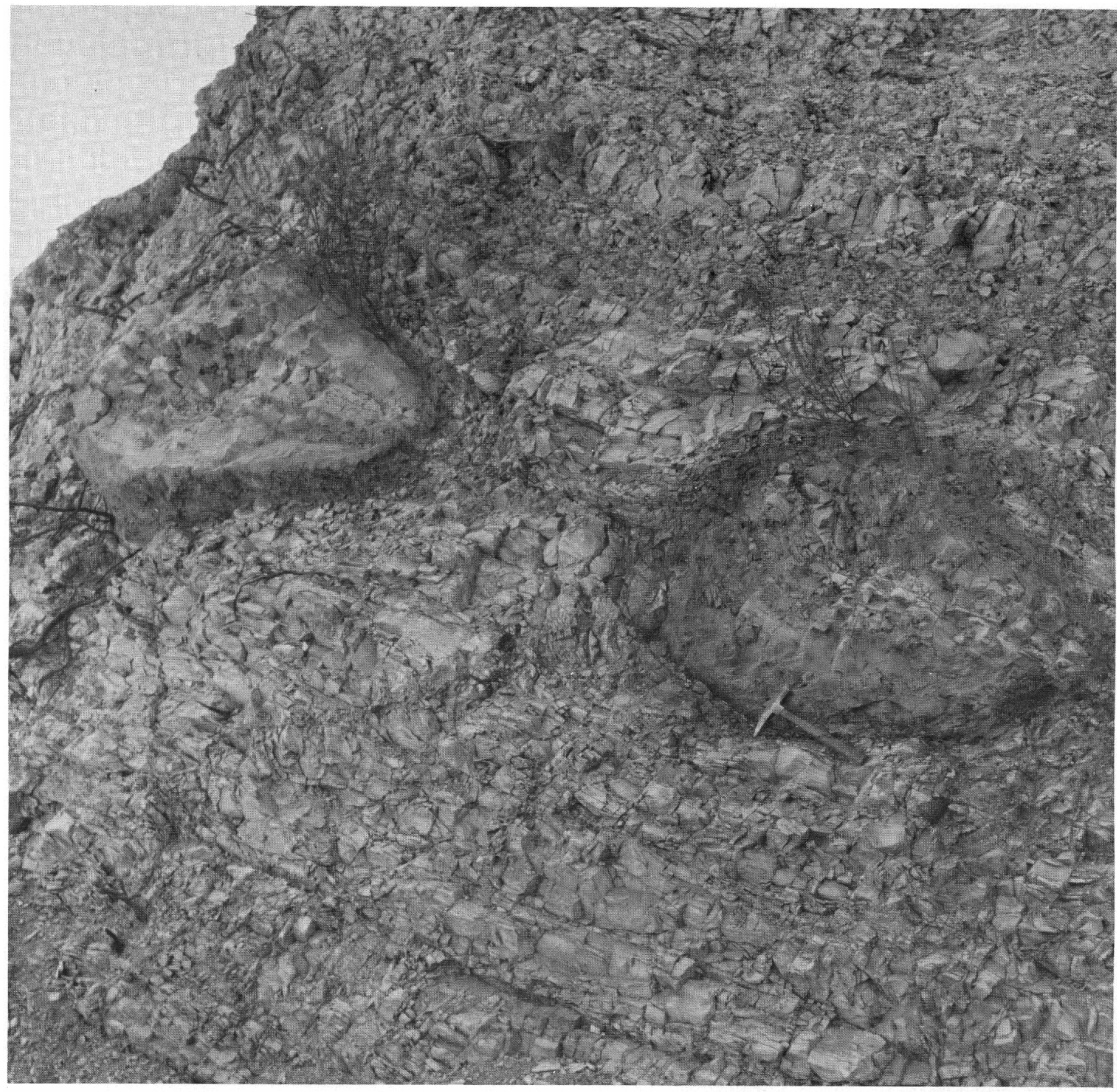

FIGURE 29.- Internal features of dolomite concretions in the Hames Member of the Monterey Formation exposed in a cut in the San Ardo oil feld, Hames Valley quadrangle. Bedding passes through the concretions, and enclosing beds bulge around them.

dimension; the pellets and nodules are in a matrix of slightly calcareous clay, silt, and fine-grained sand. The phosphorite is yellowish gray and yellowish brown.

Lenticular bodies of phosphatic material occur in calcareous mudstone of the Sandholdt Member locally, for example, at fossil locality Mf1020 along the Arroyo Seco in the Junipero Serra Peak quadrangle and at fossil locality Mf1442 along Sheepcamp Creek in the York Mountain quadrangle. The bodies are generally one-eighth to a quarter of an inch thick and a fraction of an inch to several inches long. Because they are lighter colored than the enclosing rock they form conspicuous spots and bands.

Phosphatic pellets are scattered in calcareous mudstone of the Sandholdt at some localities, for example, 
at fossil locality Mf971 near Piney Creek in the Sycamore Flat quadrangle and at fossil locality Mf786 north of Harris Creek in the Tierra Redonda Mountain quadrangle. Phosphatic pellets are exceptionally abundant in the Sandholdt near the base of the member in Jack Creek just above the junction of Jack and Paso Robles Creeks in the York Mountain quadrangle.

Volcanic Rocks

Tuff, olivine basalt, and diabase in the Monterey Formation provide evidence of volcanic activity in and near the mapped area during the deposition of the formation. Vitric tuff beds 1-18 inches thick crop out in the Monterey at widely separated places and at various stratigraphic levels, but they are most numerous in the Sandholdt Member. The tuff is massive, moderately friable, and porous; weathered tuff ranges from yellowish gray, medium light gray, and very light gray to white. Some tuff contains scattered sand grains and some has a clayey or calcareous matrix. Thin beds of bentonitic clay interspersed with porcelaneous rocks of the Monterey generally are considered to be altered volcanic ash (Bramlette, 1946, p. 26).

Olivine basalt and diabase associated with the Sandholdt Member of the Monterey Formation crop out at the head of a fork of Las Tablas Creek in the Adelaida quadrangle and on hills east of the creek in the Lime Mountain quadrangle. The deeply weathered rocks are covered with moderate-brown soil, which contrasts with lighter colored soil on the Sandholdt. Basalt in the Adelaida quadrangle has pillow structure and intertongues with the Sandholdt, which nearby contains abundant sandy basaltic debris; this evidence indicates that at least some molten rock reached the sea floor as a submarine flow, although Taliaferro (N. L. Taliaferro, unpub. field notes dated May 20, 1931) regarded the occurrence as a sill of analcite diabase that "has burned the shale considerably." The origin of the diabase in the lime Mountain quadrangle is obscure; the rock forms knobs surrounded by calcareous mudstone and shale of the Sandholdt Member.

\section{STRATIGRAPHIC RELATIONS}

The Sandholdt Member of the Monterey Formation conformably overlies the Vaqueros Formation where both units are exposed between the Arroyo Seco and Nacimiento River and conformably overlies and intertongues with the Tierra Redonda Formation north of the Arroyo Seco and south of the San Antonio and Estrella Rivers. The lower contact of the Sandholdt is at the base of the stratigraphically lowest calcareous mudstone or shale beds above the dominantly sandy Vaqueros or Tierra Redonda; the contact is gradational in that some sandstone generally is interbedded with mudstone and shale near the base of the member. Where the Sandholdt Member and Tierra Redonda Formation intertongue and rocks typical of each unit are interbedded, sequences of dominantly fine-grained rocks are assigned to the Sandholdt and sequences of dominantly sandy rocks are assigned to the Tierra Redonda. Subsurface relations between the Sandholdt and Tierra Redonda commonly are uncertain; the two units are undifferentiated on illustrations concerned with the subsurface (pl. 2, figs. 9, 22).

The Hames Member of the Monterey Formation conformity overlies the Sandholdt Member of the Monterey where both members occur. The lower contact of the Hames is at the top of the stratigraphically highest calcareous mudstone or shale beds in the Monterey; it is gradational in that some porcelaneous rocks like those in the Hames commonly are interbedded with calcareous mudstone in the upper part of the underlying Sandholdt. The contact probably is at about the same stratigraphic horizon throughout most of the mapped area, for beds at the top of the Sandholdt generally belong to the upper Luisian Stage of Kleinpell; in the southwest part of the mapped area, however, beds near the top of the Sandholdt belong to the Relizian or lower Luisian Stages (for example at fossil localities Mf1450 and Mf1458 in the York Mountain quadrangle).

The Buttle Member of the Monterey Formation conformably overlies and locally intertongues with, or grades laterally into, the Hames Member of the Monterey. The lower contact of the Buttle is at the base of the stratigraphically lowest richly diatomaceous rocks in the upper part of the Monterey; it is gradational in that siliceous mudstone and porcelaneous rocks like those in the underlying Hames Member are interbedded with diatomaceous rocks near the base of the Buttle. The intertonguing relations of the Buttle and Hames are especially well displayed north of Swain Valley in the Wunpost quadrangle, where diatomaceous and porcelaneous rocks are interbedded (Durham, 1966, measured sections 1 and 2). The absence of the Buttle Member in parts of the area seems to be the result of lateral gradation of diatomaceous into porcelaneous rocks, rather than omission of part of the stratigraphic sequence.

\section{FOSSILS}

Fossils are abundant in the Monterey Formation. Myriads of foraminifers give the Sandholdt Member its characteristic calcareous aspect, and molds and casts of foraminifers are locally plentiful in siliceous rocks of the Hames Member. Diatom frustules form the bulk of the Buttle Member; they are locally abun- 
dant in the Hames Member and less common in the Sandholdt Member. Molds and casts of clam shells, common in the formation, completely cover some bedding surfaces. Other fossils in the Monterey include teeth, bones, and scales of fish, bones of marine mammals, crustacean remains, leaves, sponge spicules, radiolarians, and silicoflagellates.

Foraminifers from 16 representative localities in the Sandholdt Member of the Monterey Formation are listed below; Patsy B. Smith identified the fossils and determined the age and correlation of the faunas in terms of the Miocene stages of Kleinpell (1938) (localities shown in figs. 22 and 23).

USGS loc.

Mf858. Adelaida quadrangle. Age and correlation: Miocene, upper Luisian Stage (outer shelf or upper bathyal depth).

Baggina californica Cushman

Bolivina advena striatella Cushman californica Cushman cuneiformis Kleinpell marginata gracillima Cushman salinasensis Kleinpell tumida Cushman

Bulimina cf. B. pseudoaffinis Kleinpell

Dentalina consobrina d'Orbigny

Epistominella capitanensis (Cushman and Kleinpell)

cf. E. gyroidinaformis (Cushman and Goudkoff) subperuviana (Cushman)

Lenticulina cf. L. miocenica (Chapman) smileyi Kleinpell

Nonionella miocenica Cushman

Pullenia miocenica globula Kleinpell

Siphogenerina branneri (Bagg) collomi Cushman

Suggrunda eckisi Natland

Uvigerina hootsi Rankin

Mf902. Bryson quadrangle. Age and correlation: Miocene, upper Saucesian Stage.

Baggina cf. B. cancriformis Kleinpell

Bolivina marginata Cushman

Bulimina rinconensis Cushman and Laiming

Cibicides of. C. americanus Cushman

Dentalina obliqua (Linné)

Plectofrondicularia sp.

Pullenia cf. P. salisburyi R. E. and K. C. Stewart

Robulus simplex d'Orbigny

Siphogenerina transversa Cushman

Mf925. Bryson quadrangle. Age and correlation: Miocene, lower Luisian Stage.

Anomalina salinasensis Kleinpell

Baggina robusta Kleinpell

Bolivina californica Cushman tumida Cushman

Bulimina pseudotorta Cushman

Cassidulina cf. C. crassa d'Orbigny

Epistominella relizensis (Kleinpell)

Lenticulina miocenicus (Chapman)

Pullenia miocenica Kleinpell
USGS loc.

Mf925. Siphogenerina branneri (Bagg) reedi Cushman

Uvigerinella californica Cushman

Valvulineria californica Cushman depressa Cushman

Virgulina californiensis Cushman

Mf1166. Junipero Serra Peak quadrangle. Age and correlation: Miocene, lower Relizian Stage (bathyal depth).

Baggina cancriformis Kleinpell

Bolivina advena striatella Cushman californica Cushman guadaloupae Parker tumida Cushman

Cassidulina cf. C. pulchella d'Orbigny

globigerinids spp.

Gyroidina reliziana Kleinpell rotundimargo $\mathbf{R}$. E. and K. C. Stewart

Planulina baggi Kleinpell

?Plectofrondicularia sp.

Pullenia cf. P. elegans d'Orbigny

Siphogenerina hughesi Cushman

Valvulineria californica obesa Cushman

Mf1189. Wilson Corner quadrangle. Age and correlation: Miocene, lower Luisian Stage.

Bolivina advena striatella Cushman imbricata Cushman tumida Cushman

Bulimina cf. B. pseudoaffinis Kleinpell

Buliminella subfusiformis Cushman

Lenticulina simplex (d'Orbigny)

Nonion costiferum (Cushman)

Siphogenerina reedi Cushman

Uvigerinella californica Cushman

Valvulineria californica californica Cushman depressa Cushman miocenica Cushman

Mf1191. Santa Margarita quadrangle. Age and correlation: Miocene, lower Relizian Stage.

Anomalina patella (Egger)

Baggina cancriformis Kleinpell

Bolivina advena striatella Cushman californica Cushman cuneiformis Kleinpell tumida Cushman

Cassidulina crassa d'Orbigny

Planulina baggi Cushman

Plectofrondicularia californica Cushman

Pullenia subcarinata

Siphogenerina hughesi Cushman kleinpelli Cushman

Stilostomella advena (Cushman)

Mf1441. York Mountain quadrangle. Age and correlation: Miocene, lower Relizian Stage.

Baggina cancriformis Kleinpell

Bolivina brevior Cushman californica Cushman conica Cushman tumida Cushman

Bulimina ovula d'Orbigny

Buliminella curta Cushman Cancris baggi Cushman and Kleinpell Cassidulina cf. C. crassa d'Orbigny 
USGS loc. Mf1441.

\author{
Epistominella sp. \\ Eponides sp. \\ Marginulina sp. \\ Nonion sp. \\ Planulina baggi Kleinpell \\ Pseudopolymorphina sp. \\ Pullenia miocenica Kleinpell \\ Siphogenerina hughesi Cushman \\ Uvigerina subperegrina Cushman and Klein- \\ pell \\ Valvulineria californica Cushman \\ depressa Cushman \\ Virgulina californiensis Cushman
}

Mf1442. York Mountain quadrangle. Age and correlation:

Miocene, Saucesian Stage.

Anomalina glabrata Cushman

Bolivina advena Cushman marginata Cushman

Bulimina alligata Cushman and Laiming

Dentalina quadrulata Cushman and Laiming

Lenticulina miocenica (Chapman) reedi (Kleinpell)

Siphogenerina transversa Cushman

Uvigerinella obesa Cushman

Mf1446. Templeton quadrangle. Age and correlation: Miocene, Saucesian Stage.

Anomalina glabrata Cushman

Baggina robusta Kleinpell

Bolivina advena striatella Cushman californica Cushman cuneiformis Kleinpell guadaloupae Parker

Bulimina inflata alligata Cushman and Laiming

Buliminella subfusiformis Cushman

Cassidulina cf. C. panzana Kleinpell

Dentalina obliqua (Linné)

Lenticulina miocenica (Chapman) simplex (d'Orbigny)

Nonion incisum (Cushman) sp.

Plectofrondicularia californica Cushman and Stewart miocenica Cushman

Pullenia miocenica Kleinpell

Saracenaria beali (Cushman)

Siphogenerina transversa Cushman

Valvulineria williami Kleinpell

Virgulina californiensis Cushman

Mf1449. Lime Mountain quadrangle. Age and correlation: Miocene, Saucesian Stage (bathyal depth).

Bolivina marginata Cushman marginata adelaidana Cushman and Kleinpell

Bulimina cf. B. rinconensis Cushman and Laiming

Buliminella curta Cushman subfusiformis Cushman

Chilostomella sp.

Cibicides americanus crassiseptus Cushman and Laiming

Dentalina quadrulata Cushman and Laiming

Nonion incisum (Cushman)
USGS loc.

Mf1449.

Plectofrondicularia miocenica Cushman

Siphogenerina transversa Cushman

Uvigerina cf. $U$.gallowayi Cushman ef. U. hispido-costata Cushman and Todd

Uvigerinella obesa Cushman obesa impolita Cushman and Laiming

Valvulineria casitasensis subcasitasensis

Kleinpell

Virgulina bramlettei Galloway and Morrey

Mf1455. Atascadero quadrangle. Age and correlation: Miocene, lower Relizian Stage (lower(?) bathyal depth).

Baggina cancriformis Kleinpell robusta Kleinpell

Bolivina advena Cushman brevior Cushman californica Cushman cuneiformis Kleinpell

Bulimina pseudoaffinis Kleinpell

Buliminella subfusiformis Cushman

Cibicides americanus (Cushman) relizensis Kleinpell

Epistominella relizensis (Kleinpell)

Gyroidina reliziana Kleinpell

Plectofrondicularia miocenica Cushman and Laiming

Siphogenerina hughesi Cushman

Virgulina californiensis. Cushman

Mf1465. Reliz Canyon quadrangle. Age and correlation: Miocene, lower Luisian Stage.

Anomalina salinasensis Cushman

Baggina robusta Cushman

Bolivina advena striatella Cushman brevior Cushman curta Cushman

Bulimina montereyana Kleinpell

Buliminella subfusiformis Cushman

Cassidulina cf. C. williami Kleinpell

globigerinids spp.

Siphogenerina branneri (Bagg)

Valvulineria californica Cushman depressa Cushman

Virgulina californiensis Cushman

Mf1473. Bryson quadrangle. Age and correlation: Miocene, lower Relizian Stage.

Baggina robusta Kleinpell

Bolivina advena striatella Cushman salinasensis Kleinpell tumida Cushman

Bulimina pseudoaffinis Kleinpell

Cassidulina panzana Kleinpell globigerinids spp.

Lenticulina sp.

Nonion cf, $N$. costiferum (Cushman)

Pullenia miocenica Kleinpell

Siphogenerina branneri (Bagg) kleinpelli Cushman

Uvigerinella obesa Cushman

Valvulineria depressa Cushman

Virgulina californiensis Cushman

Mf1482. Reliz Canyon quadrangle. Age and correlation: Miocene, upper(?) Saucesian Stage.

Baggina robusta Kleinpell 
USGS loc. Mf1482.

Mf1483. Reliz Canyon quadrangle. Age and correlation: Miocene, lower Relizian Stage.

Angulogerina? sp.

Anomalina salinasensis Kleinpell

Baggina cancriformis Kleinpell robusta Kleinpell

Bolivina advena Cushman advena striatella Cushman californica Cushman imbricata Cushman marginata Cushman salinasensis Kleinpell

Buliminella curta Cushman subfusiformis Cushman

Epistominella cf. E. capitanensis Cushman and Kleinpell relizensis (Kleinpell)

Eponides keenani Cushman and Kleinpell

globigerinids spp.

Siphogenerina branneri (Bagg) cf. S. branneri (Bagg) hughesi Cushman

Uvigerinella californica Cushman obesa Cushman

Valvulineria depressa Cushman williami Kleinpell

Mf1497. Reliz Canyon quadrangle. Age and correlation: Miocene, upper Luisian Stage.

Anomalina silinasensis Kleinpell

Baggina californica Cushman

Bolivina advena Cushman advena striatella Cushman imbricata Cushman marginata Cushman ovata d'Orbigny tumida Cushman

Bulimina montereyana Kleinpell

Buliminella subfusiformis Cushman

Cassidulina crassa d'Orbigny

globigerinids spp.

Nonion costiferum (Cushman)

Planulina? sp.

Pullenia miocenica globula Kleinpell

Saracenaria beali (Cushman)
USGS loc.

Mf1497.

\author{
Siphogenerina cf. S. branneri (Bagg) \\ collomi Cushman \\ kleinpelli Cushman \\ Uvigerinella californica Cushman \\ Valvulineria californica Cushman \\ californica appressa Cushman \\ Virgulina californiensis grandis Cushman and \\ Kleinpell
}

\section{AGE AND CONDITIONS OF DEPOSITION}

Both the stratigraphic position and the fossils of the Monterey Formation establish a Miocene age for the unit. Fossil foraminifers in the Sandholdt Member represent the Miocene Saucesian, Relizian, and Luisian Stages of Kleinpell (1938); the general distribution is indicated in figure 30. Fossil mollusks in the Sandholdt belong to the middle Miocene "Temblor Stage" of the Pacific Coast megainvertebrate sequence (Weaver and others, 1944). The underlying Vaqueros Formation contains fossils of the lower Miocene "Vaqueros Stage" of the Pacific Coast megainvertebrate sequence, and the underlying and intertonguing Tierra Redonda Formation contains fossils of the middle Miocene "Temblor Stage." Relation of the Hames Member with the underlying and intertonguing Santa Margarita Formation, which contains fossils of late Miocene age, and the relation of the Hames and Buttle Members with the overlying Pancho Rico Formation, which contains fossils of early Pliocene age, demonstrate the accumulation of the Monterey mainly during middle and late Miocene time. Fossils of the Hames and Buttle Members generally are of little value in determining the age of the uppermost Monterey beds. The age of the uppermost part of the Monterey cannot be established in most places on the basis of fossils.

The abundance of marine fossils throughout the Monterey Formation demonstrates the marine origin of the unit. Foraminiferal faunas in the Sandholdt Member generally suggest bathyal depth. However, some Relizian or Saucesian Stage faunas suggest lower bathyal or abyssal depth and some Luisian Stage faunas indicate upper bathyal and neritic depth; these departures from the general bathyal-depth indications seem to show a decrease in average depth of water from the beginning to the end of deposition of the Sandholdt. According to Smith (1968, p. 1790), pelletal phosphate beds near the base of the Hames Member in Reliz Canyon and near Indian Creek were deposited at water depth of 200 feet or less, and foraminiferal faunas at both places record an abrupt decrease in water depth near the top of the Sandholdt. Fossil mollusks in the Santa Margarita Formation, with which the Hames Member of the Monterey intertongues locally, indicate a shallow-water marine environment. 


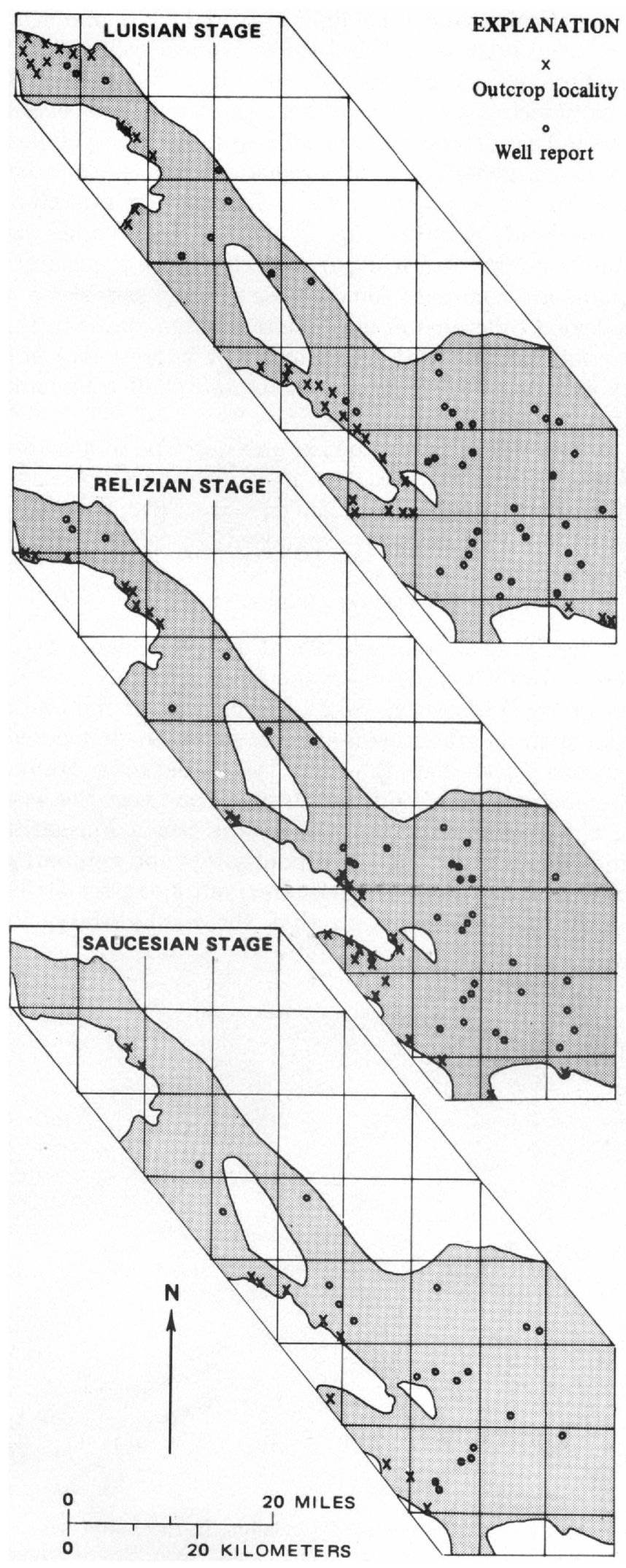

\section{SANTA MARGARITA FORMATION}

NOMENCLATURE

The Santa Margarita Formation contains sandy beds that are stratigraphically equivalent to finer grained rocks in the Hames Member of the Monterey Formation. Antisell (1855) first described fossiliferous sandstone beds in the southern Salinas Valley area that Fairbanks (1904a, p. 4) later named "Santa Margarita Formation" for exposures near the town of Santa Margarita (fig. 1). The term "Santa Margarita" came to be applied almost indiscriminately to all marine sandstone beds that overlie the Monterey Formation in the mapped area, including those here placed in the Pancho Rico Formation (Hamlin (1904, p. 15, 18), Pack and English (1915, p. 133), English (1918, p. 229, $231)$, Reed (1925, p. 593), Kleinpell (1930, p. 30), Clark (1930, p. 781,782$)$, Taliaferro (1943b, p. 459 , $460)$, and Bramlette and Daviess (1944)). Restriction of the term "Santa Margarita" in the mapped area to strata that are similar to the type Santa Margarita Formation both in lithologic character and stratigraphic position (Durham and Addicott, 1964, p. E3) allows a more exact definition of the unit and reduces the confusion of the Santa Margarita with the Pancho Rico. The Santa Margarita is here considered a dominantly sandy formation that overlies and locally intertongues with the Hames Member of the Monterey; it is the sandy stratigraphic equivalent of the upper part of the Hames Member and of the Buttle Member of the Monterey, and it lies stratigraphically below the Pancho Rico and Paso Robles Formations.

\section{DISTRIBUTION AND THICKNESS}

The Santa Margarita Formation crops out near Atascadero, along the Nacimiento and San Antonio Rivers, at the north end of the La Panza Range, and near Vineyard Canyon; it extends in the subsurface across the southeastern part of the mapped area and northward around high places on the basement-complex surface, where conditions were favorable for deposition of sand rather than fine-grained sediments of the Hames and Buttle Members of the Monterey (fig. 23). Where strata in the upper part of the Monterey impinge upon the basement complex (fig. 9), the finegrained rock of the Hames gives way to sandstone of the Santa Margarita. Exposures of the Santa Margarita are nearly continuous from near Atascadero to the

FIGURE 30.-General distribution of foraminiferal faunas of the Miocene Saucesian, Relizian, and Luisan Stages of Kleinpell (1938) in the southern Salinas Valley area. Shaded area shows approximate extent of the Sandholdt Member of the Monterey Formation. (Quadrangles identified in fig. 2) 
type area of the formation near the town of Santa Margarita (fig. 1). Outcrops of the Santa Margarita near the San Antonio and Nacimiento Rivers are west of the Jolon fault; the formation is absent nearby east of the fault, where the Hames Member of the Monterey occupies the stratigraphic position of the Santa Margarita. The difference in the sequence of upper Miocene rocks on the two sides of the Jolon fault is attributed to right-lateral displacement along the fault (Durham, 1965b).

If the Santa Margarita Formation and the contemporaneous Hames and Buttle Members of the Monterey Formation are considered together (fig. 23), the Santa Margarita is the sandy part of the combined unit and has two principal forms, one with an obvious nearby source for the sand, the other without. The first form occurs where the combined unit lies on or near the basement complex, which provided a ready sand source; productive zones in the San Ardo and most other oil fields in the mapped area belong in this category. The second form occurs as tongues and sheets of sandstone well above the base of the combined unit in areas where beds considerably older than the Santa Margarita cover nearby sand sources. Santa Margarita in this category is best developed in the southeastern part of the mapped area, where the distribution and thickness variation of the Santa Margarita suggest a sand source to the east across the San Andreas fault zone.

The lenticularity and intertonguing of the Santa Margarita Formation make thickness estimates for the unit uncertain, but the exposed thickness of the formation generally is at least $500 \mathrm{ft}$. The outcrop thickness is about $600 \mathrm{ft}$ in the Atascadero quadrangle and about $500 \mathrm{ft}$ near the Nacimiento River. The outcrop thickness is about $1,000 \mathrm{ft}$ in the Wilson Corner quadrangle, but well data show that the thickness increases northward in the subsurface to $3,500-4,000 \mathrm{ft}$ in the northern part of the Shandon quadrangle. The Santa Margarita is split by a tongue of the Monterey Formation in the subsurface of the Stockdale Mountain and adjacent Ranchito Canyon quadrangles; the thickness there of the lower part of the Santa Margarita is 1,500$2,000 \mathrm{ft}$ and the thickness of the upper part is $600-800$ $\mathrm{ft}$. Well data indicate that the thickness of the Santa Margarita is as great as 2,000 $\mathrm{ft}$ in the center of the Valleton quadrangle, $1,500 \mathrm{ft}$ in the northeastern part of the Wunpost quadrangle, and $1,000 \mathrm{ft}$ in the San Miguel and Estrella quadrangles. The formation thins westward and pinches out near the Salinas River.

\section{LITHOLOGY}

The Santa Margarita Formation is chiefly and char- acteristically sandstone, light gray and white and massive or in beds several feet thick. It most commonly is medium or coarse grained, although the formation locally includes very fine grained sandstone and coarsegrained sandstone that contains granules and pebbles. The rock generally is calcareous and ranges from friable to well cemented; the well-cemented sandstone forms bold outcrops (fig. 31). The sand grains are chiefly quartz and feldspar, but chert and porcelanite grains are common; some coarse-grained sandstone is speckled by grains of dark chert. Coarse grains in the sandstone generally are rounded or subrounded and many are polished. Fossil shells and shell fragments are abundant in some beds.

Vitric tuff beds crop out at and near the base of the Santa Margarita Formation in the Wilson Corner and Atascadero quadrangles. The tuff is massive, light gray to white, and generally composed almost entirely of shards.

\section{STRATIGRAPHIC RELATIONS}

The Santa Margarita Formation conformably overlies and intertongues with the Hames Member of the Monterey Formation. The lower contact of the Santa Margarita is gradational at most places in that porcelaneous rocks like those in the underlying Hames Member are interbedded with sandstone near the base of the Santa Margarita. Where the Santa Margarita and Hames intertongue, units of sandstone and porcelaneous rocks alternate and pinch out along the strike of the beds. The notion that the Santa Margarita

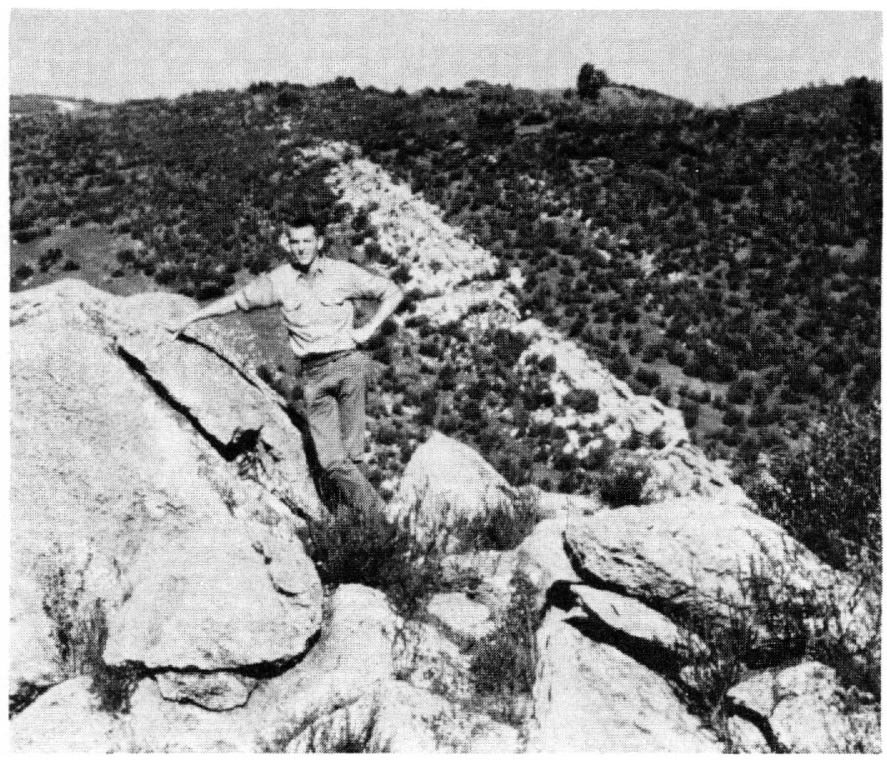

FIGURE 31.-Bold outcrops of sandstone in the Santa Margarita Formation north of the Nacimiento River, Bradley quadrangle. The rock is highly calcareous and resistant to erosion; the weathered surface is rough and resembles the surface of solution-etched limestone. 
unconformably overlies the Monterey in the mapped area (Fairbanks, 1904a, p. 4; Arnold and Johnson, 1910, p. 63; Anderson and Martin, 1914, p. 45; Taliaferro, $1943 a$, p. $140 ; 1943 b$, p. 459 ) seems to result from mistaking faults for depositional contacts.

The lower contact of the Santa Margarita Formation is well exposed in a roadcut about 600 feet south of the San Antonio Dam spillway in the Tierra Redonda Mountain quadrangle (Durham, 1968a, fig. 4) and in a roadcut east of the Nacimiento River between the San Marcos and Jolon faults in the Bradley quadrangle; at both places, sandstone and porcelaneous rocks are interbedded near the base of the Santa Margarita. The base of the Santa Margarita in the Wilson Corner quadrangle is marked by a unit of vitric tuff that conformably overlies porcelaneous rocks of the Hames Member; similar tuff is at the base of the Santa Margarita at places in the Atascadero quadrangle.

Intertonguing of the Santa Margarita Formation and the Hames Member of the Monterey Formation is conspicuous in the Stockdale Mountain quadrangle, where a tongue of Santa Margarita sandstone extends for about 2 miles northwest of Portuguese Canyon, then pinches out northwestward in a thin zone of sandy porcelanite in the Hames Member. Porcelaneous rocks that are stratigraphically above the tongue of Santa Margarita in Portuguese Canyon form a complementary tongue of the Hames Member that thins southeastward toward Middle Fork, where it overlies fossiliferous sandstone typical of the Santa Margarita and underlies a unit of unfossiliferous massive white sandstone assigned to the Santa Margarita, mainly on lithologic character. Lenticular units of porcelaneous rocks in the southern part of the Stockdale Mountain quadrangle and in the northern part of the Ranchito Canyon quadrangle are interpreted as tongues of the Hames that lack an exposed connection with the main body of the member.

The Santa Margarita Formation lies directly on the basement complex in the subsurface near the Gabilan and Lockwood highs (pl. 3). Records of wells near the highs commonly show conglomerate or granitic rubble near the base of the formation.

\section{FOSSILS}

Fossils are common in most exposures of the Santa Margarita Formation, and some beds are composed almost entirely of fragments of mollusks, echinoids, and barnacles. Larger invertebrate fossils from four representative localities are listed below. W. $O$. Addicott identified the fossils and determined the age and correlation of the faunas as late Miocene, "Margaritan Stage."
USGS loc.

M1969. Stockdale Mountain quadrangle.

Brachiopod:

Discinisca cumingi Broderip of Hertlein and Grant (1944)

Gastropods:

Neverita sp.

Turritella gonostoma hemphilli Merriam

Pelecypods:

Anadra sp.

Arca? cf. A. santamariensis Reinhart

Cryptomya cf. C. californica Conrad

Florimetis biangulata (Carpenter)

Lucinisca n. sp. aff. L. nuttalli (Conrad)

Lucinoma cf. L. annulata (Reeve)

Lyropecten estrellanus (Conrad)

Macoma nasuta (Conrad)?

Macoma? cf. $M$. n. sp. Woodring [and Bramlette] (1950)

Panopea abrupta (Conrad)

Spisula hemphilli (Dall)?

Trachycardium quadragenarium (Conrad)?

M3954. Stockdale Mountain quadrangle.

Gastropods:

Calyptraea sp.

Nassarius?

Pelecypods:

Anadara cf. A. montereyana (Osmont)

Chione (Chionopsis?) sp.

Cryptomya?

Lucinisca n. sp. aff. L. nuttalli (Conrad)

Lyropecten cf. L. estrellanus (Conrad)

Macoma nasuta (Conrad)

Yoldia sp.

Barnacle:

Balanus gregarius (Conrad)

M4008. Stockdale Mountain quadrangle.

Gastropods:

Calyptraea filosa (Gabb)

Cancellaria sp.

Nassarius?

Neverita?

Trophosycon kerniana (Cooper)

Turritella cooperi Carpenter

Pelecypods:

Anadara sp.

Crassostrea titan (Conrad)

Dosinia sp.

Lucinisca?

Macoma sp.

M4072. Stockdale Mountain quadrangle.

Brachiopod:

Discinisca sp.

Gastropods:

Neverita cf. N. alta Arnold recluziana (Deshayes)

Sinum trigenarium Trask

Pelecypods:

Chione semiplicata (Nomland)

Crassostrea titan (Conrad)

Cryptomya

Dosinia cf. $D$. merriami Clark

Lirophora n. sp.

Lucinisca n. sp. aff. L. nuttalli (Conrad) 
USGS loc. M4072.

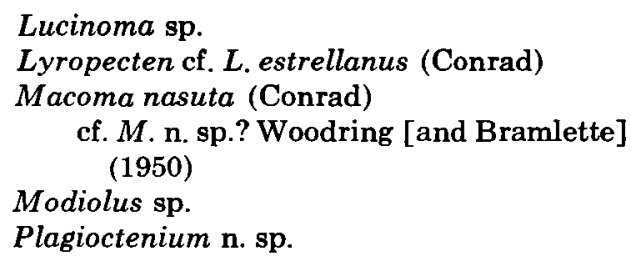

AGE AND CONDITIONS OF DEPOSITION

Fossils and the stratigraphic position of the Santa Margarita Formation indicate that the unit is late Miocene. According to W. O. Addicott (written communs., 1963-70), the fossils are generally indicative of late Miocene age as that term is used in the Pacific Coast megainvertebrate chronology (Weaver and others, 1944). Crassostrea titan, characteristic of shallow-water strata of late Miocene age in central California, is unreported from strata of Pliocene age (W. 0 . Addicott, written commun., 1964).

Fossils in the Santa Margarita Formation demonstrate the shallow-water marine origin of most of the unit. The stratigraphically lowest beds of the Santa Margarita in the Stockdale Mountain quadrangle could be nonmarine; they are unfossiliferous and include conglomerate and red beds that have a nonmarine aspect. According to W. O. Addicott (written communs., 1968, 1969), fossil assemblages from the Santa Margarita suggest deposition in the upper part of the inner sublittoral zone, $0-15$ fathoms, and a warm-temperate to subtropical marine climate.

\section{PLIOCENE SERIES}

\section{PANCHO RICO FORMATION}

\section{NOMENCLATURE}

The Pancho Rico Formation consists of marine beds that conformably overlie the Monterey Formation at most places in the northern part of the mapped area (Durham and Addicott, 1964, p. E4; 1965, p. A2) and unconformably overlie the basement complex where the Monterey is absent in that part of the area. The unit can and should be discriminated from the Santa Margarita Formation because the Pancho Rico lies stratigraphically above the Hames and Buttle Members of the Monterey Formation, and because the Santa Margarita is the stratigraphic equivalent of those members. Eldridge (1901, p. 408) assigned beds in the Pancho Rico northeast of King City to the San Pablo Formation and Monterey Shale. English (1918, p. 231) assigned part of the Pancho Rico to the Jacalitos and Etchegoin Formations, which crop out on the west side of the San Joaquin Valley (fig. 1). Reed (1925, p. 606) gave the name "Poncho Rico
Formation" to marine "diatomite $* * *$ clastic shale, yellowish sandstone, and conglomerate beds" that are exposed on the east side of the Salinas Valley; presumably he intended that the marine strata along Pancho Rico Creek should be considered typical of the formation. Clark (1940) used the name "King City Formation" for beds that he believed underlie the Poncho Rico Formation of Reed. Taliaferro (1943b, p. 460) assigned much of the Pancho Rico to the Etchegoin Formation.

\section{DISTRIBUTION AND THICKNESS}

The Pancho Rico Formation crops out extensively east of the Salinas River and west of the river in scattered belts and patches (fig. 32). The formation extends farther south on the east side of the Jolon fault than on the west side, a circumstance attributed to strike-slip displacement along the fault (Durham, $1965 \mathrm{~b})$. The difficulty of distinguishing the Pancho Rico from the Santa Margarita Formation in well records makes the subsurface extent of the Pancho Rico uncertain at some places. The formation is absent in the southern part of the mapped area, where nonmarine beds of the Paso Robles Formation presumably occupy the stratigraphic position of the Pancho Rico.

The Pancho Rico Formation is thickest near the mouth of the Arroyo Seco, where it is about $1,250 \mathrm{ft}$ thick, and east of Reliz Canyon, where it may be greater than $1,000 \mathrm{ft}$ thick. The thickness is about 900 feet in the western part of the Cosio Knob quadrangle, about 200 feet near the San Antonio River in the Williams Hill quadrangle, 100-200 feet north of Swain Valley in the Wunpost quadrangle, and as little as 20 feet south of the Nacimiento River in the Adelaida quadrangle. The thickness east of the Salinas River is 450-550 feet near Sargent Canyon in the Wunpost quadrangle and near Pine Valley in the San Ardo quadrangle; and it is only about 275 feet near Sweetwater Canyon in the San Lucas quadrangle. The Pancho Rico thins and pinches out southward in the subsurface in the southern part of the mapped area.

\section{LITHOLOGY}

The Pancho Rico Formation is chiefly and characteristically sandstone, but the unit also contains conglomerate, mudstone, diatomite, and porcelanite. The sandstone generally is finer grained, thinner bedded, and less fossiliferous than most sandstone in the Santa Margarita Formation, with which the Pancho

"The formation name came from the geographic name "Poncho Rico Creek," which was changed to "Pancho Rico Creek." The spellings "Poncho but "Pancho Rico" is preferred (Durbam and Addicott, 1965, p. A2). 


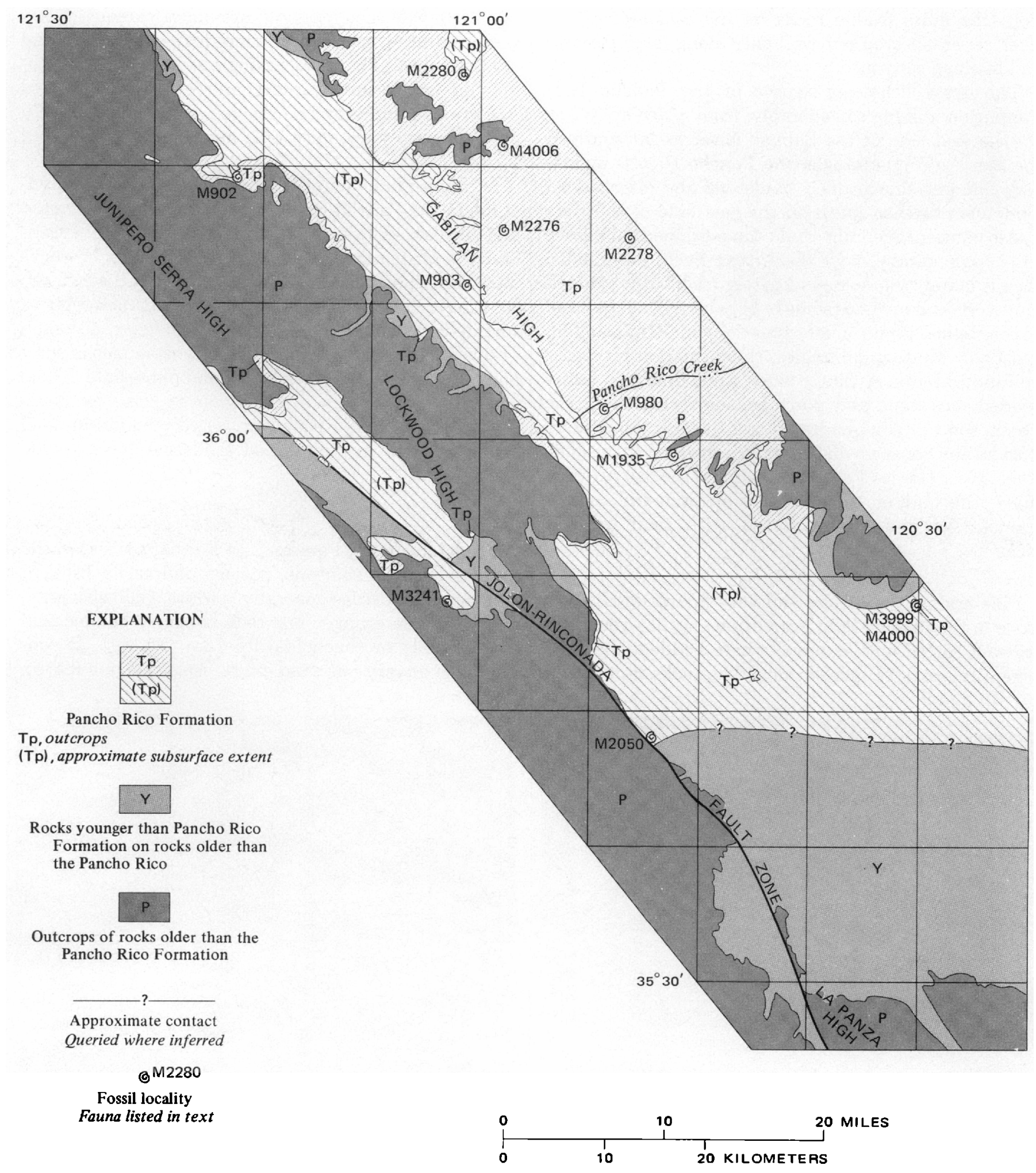

Figurg 32.-Approximate distribution of the Pancho Rico Formation in the southern Salinas Valley area. Small outcrop areas are omitted, including some where fossil localities are indicated (quadrangles identified in fig. 2).

Rico is easily confused. The Pancho Rico generally $\mid$ rocks in the unit west of the Salinas River resembles lacks bold outcrops. The outcrop habit of fine-grained that of porcelaneous rocks in the Monterey Forma- 
tion; the more friable rocks on the east side of the river generally crop out well only along large streams and in steep canyons.

The gross lithologic aspect of the Pancho Rico Formation differs considerably from place to place. On the east side of the Salinas River as far south as the San Ardo quadrangle, the Pancho Rico is mainly very fine and fine-grained sandstone and interbedded mudstone; farther south on the east side of the river it also contains medium- and coarse-grained sandstone and conglomerate. Near the Arroyo Seco, the Pancho Rico is mainly massive moderately friable fine-grained sandstone and includes some pebbly beds near the base. In the Reliz Canyon, Thompson Canyon, Bear Canyon, and Cosio Knob quadrangles, the formation is mainly well-indurated very fine grained sandstone and interbedded mudstone and porcelaneous rocks. From the Thompson Canyon quadrangle southward, the Pancho Rico locally contains diatomite interbedded with sandstone. Near Hames Valley and south of the San Antonio River, the unit includes beds of medium-and coarsegrained sandstone interspersed with finer grained rocks.

SANDSTONE

Fine-grained sandstone and very fine grained sandstone in the Pancho Rico Formation (fig. 33) generally are well sorted and massive; where bedded, the beds generally are 6-24 inches thick. The rocks range from

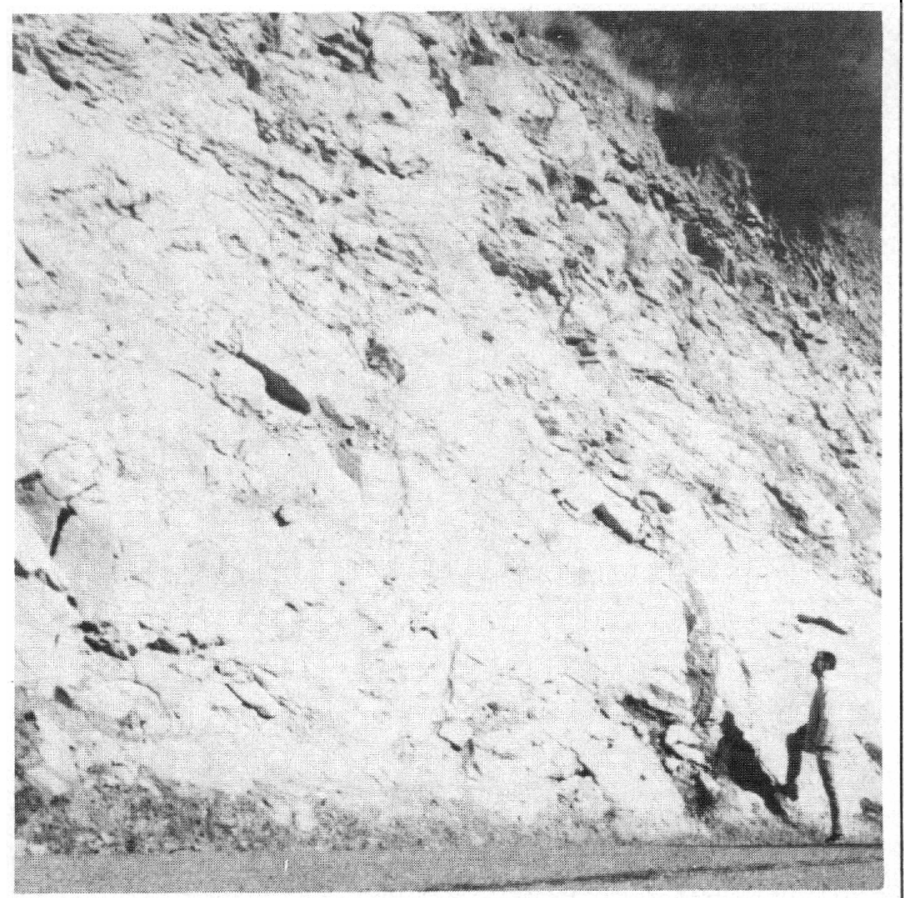

Figure 33. - Massive very fine grained sandstone in the Pancho Rico Formation exposed in a roadcut in Reliz Canyon, Reliz Canyon quadrangle. friable to well cemented and are noncalcareous. A few well-indurated beds are cemented by chalcedony and opaline silica. The sand grains are angular and subangular and are mainly quartz and feldspar. Weathered fine-grained and very fine grained sandstone generally are yellowish gray, very pale orange, light gray, and white.

Medium-grained sandstone and coarse-grained sandstone in the Pancho Rico Formation are poorly sorted and locally contain granules and pebbles; they generally form massive units $2-20$ feet thick. The rocks are mainly noncalcareous, but some are well cemented by calcite. The sand grains range from subangular to rounded and are mainly quartz and feldspar, although grains of chert and porcelanite are conspicuous in some beds. Rounded glauconite grains and phosphate pellets occur in coarse-grained sandstone at some localities east of the Salinas River. Weathered medium-grained sandstone and coarse-grained sandstone have a wide color range.

\section{MUdSTONE}

Mudstone in the Pancho Rico Formation east of the Salinas River is siliceous, porous, and easily broken; weathered mudstone generally is white, yellowish gray, and very pale orange. The rock is poorly bedded and has a hackly or conchoidal fracture (fig. 34). It contains fine or very fine sand grains scattered in a matrix

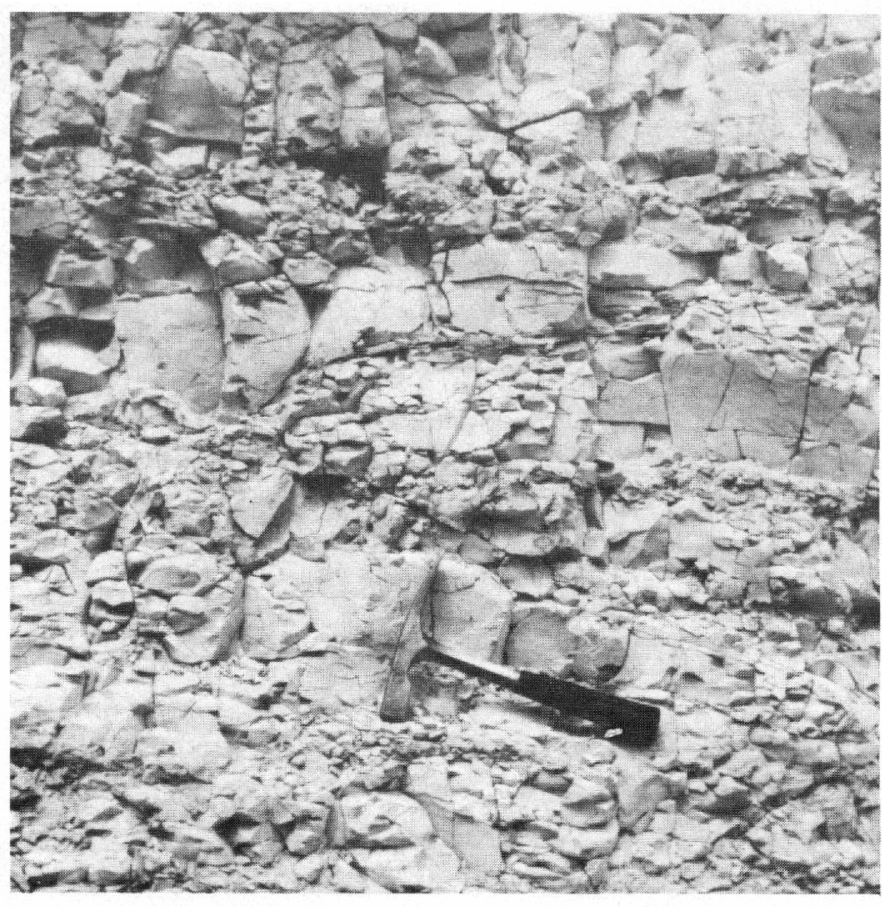

Figure 34.-Poorly bedded mudstone in the Pancho Rico Formation exposed in roadcut south of Long Valley, Monarch Peak quadrangle. The beds are flat lying. 
of silt and clay and includes abundant diatom frustules, fish scales, and imprints of mollusk shells. Mudstone in the Pancho Rico west of the Salinas River generally is hard siliceous rock similar to mudstone in the Monterey Formation.

\section{Conglomerate}

Conglomerate in the Pancho Rico Formation east of the Salinas River forms massive beds 2-5 feet thick that are interspersed with units of finer grained rock. Pebbles and cobbles in the conglomerate generally are rounded or subrounded and consist of porcelanite, chert, volcanic rocks, quartzite, gneiss, and granitic rock. The relative abundance of the kinds of clasts varies from place to place, but the variation lacks an obvious pattern. A distinctive conglomerate in the upper part of the Pancho Rico east of the river contains pebbles and granules of porcelaneous rocks and abundant organic debris-fish teeth and bones, echinoid spines, and casts of mollusk shells-scattered in a matrix of mudstone and very fine grained sandstone; the rock clasts and organic material have a grayishbrown phosphatic coating. These distinctive beds are 1-2 $\mathrm{ft}$ thick and are pale orange or dark yellowish orange in contrast to the generally lighter colored enclosing beds.

\section{STRATIGRAPHIC RELATIONS}

The Pancho Rico Formation conformably overlies the Monterey Formation at most places, but it overlaps the Monterey to lie on the basement complex in the northeastern part of the mapped area. The lower contact of the Pancho Rico, where the unit overlies the Hames or Buttle Members of the Monterey, is at the base of the stratigraphically lowest sandstone bed above porcelaneous or diatomaceous rocks of the Monterey. The contact is gradational in that rocks similar to those in the Monterey commonly are interbedded with sandstone near the base of the Pancho Rico. The Pancho Rico overlies the Santa Margarita Formation in the subsurface south of Indian Valley. A previously published statement that the Pancho Rico and Santa Margarita are both exposed in Vineyard Canyon (Durham and Addicott, 1965, p. A10) is incorrect; additional work has shown that all marine strata exposed in Vineyard Canyon belong in the Santa Margarita Formation.

\section{FOSSILS}

Fossils are abundant in the Pancho Rico Formation at many places. They are most common in mediumand coarse-grained sandstone beds east of the Salinas River, least common in massive very fine grained sandstone beds west of the river. Mollusks, barnacles, and echinoids are the most conspicuous, but there are also brachiopods, foraminifers, diatoms, and fish remains. Larger invertebrate fossils from 12 representative localities are listed below; W. $O$. Addicott identified the fossils and determined the age of the faunas as early Pliocene (localities shown in fig. 32). USGS loc.

M902. Reliz Canyon quadrangle.

Brachiopods:

Discinisca sp.

Terebratalia arnoldi Hertlein and Grant

Gastropods:

Calyptraea filosa (Gabb)

Cancellaria? sp.

Ceratostoma foliatum (Gmelin)?

Crepidula n. sp. aff. C. aculeata (Gmelin)

Diodora? sp.

Nassarius sp.

Ocenebra sp.

Turcica cf. T. caffea brevis Stewart

Turritella n. sp. [T. broderipiana stock]

Pelecypods:

Anadara trilineata (Conrad)

Chlamys cf. C. hodgei (Hertlein)

n. sp. aff. C. nipponensis Kuroda

Glycymeris sp.

Lucinisca n. sp. aff. L. nuttalli (Conrad)

Macoma sp.

Ostrea atwoodi Gabb

Protothaca sp.

Barnacles:

Balanus gregarius (Conrad)?

M903. San Lucas quadrangle.

Echinoids:

Astrodapsis cf. A. fernandoensis Pack

cf. A. spatiosus Kew

sp.?

Dendraster sp.

Gastropods:

Acanthina n. sp.

Calliostoma coalingense Arnold

Calyptraea sp.

Ceratostoma foliatum (Gmelin) nuttalli (Conrad)?

Epitonium cf. E. eelense Durham

Forreria belcheri (Hinds)? cf. $F$. coalingensis (Arnold)

Megasurcula n. sp. aff. $M$. wynoochensis (Weaver)?

Ocenebra cierboensis (Grant and Eaton) n. sp.

Thais collomi Carson

Turritella cooperi Carpenter

Pelecypods:

Anomia? sp.

Atrina sp.

Chione cf. C. fernandoensis English

Chlamys sp.

Glycymeris sp.

Lima cf. L. hemphilli Hertlein and Strong Lyropecten cf. L. estrellanus (Conrad)

Milthasp.

Mytilus sp. 
USGS loc. M903.

Panopea abrupta (Conrad) Tellina cf. T. idae Dall

Barnacles:

Balanus gregarius (Conrad)

M980. Pancho Rico Valley quadrangle. Echinoids:

Astrodapsis arnoldi Pack

Gastropods:

Bittium casmaliense Bartsch sp.

Calicantharus cf. C. fortis (Carpenter) cf. C. fortis forma angulata (Arnold) kettlemanensis (Arnold)

Calliostoma? aff. C. cammani Dall

Calliostoma sp.

Calyptraea sp.

Cancellaria cf. C. fernandoensis Arnold?

Clavus coalingensis (Arnold)

Crassispira sp.

Crepidula nummaria Gould cf. C. onyx Sowerby

sp.

Crucibulum (Dispotaea) n. sp.

Elaeocyma empyrosia (Dall)?

Forreria belcheri (Hinds)

Megasurcula n. sp. aff. M. wynoocheensis (Weaver)

Mitrella? sp.

Neverita recluziana (Deshayes)

Ocenebra? sp.

Turritella cooperi Carpenter vanvlecki Arnold n. sp. [T. broderipiana stock]

Pelecypods:

Anadara (Anadara) trilineata (Conrad)

Cryptomya californica Conrad

Florimetis biangulata (Carpenter)

Here excavata (Carpenter)

Lucinisca n. sp. aff. L. nuttalli (Conrad)

Lyropecten terminus (Arnold)

Macoma nasuta (Conrad)

Mya cf. M. arenaria Linné

Ostrea atwoodi Gabb

Panopea abrupta (Conrad)

Protothaca cf. P. lacinata hannibali (Howe) tenerrima (Carpenter)

Solen perini Clark?

Spisula mercedensis Packard

Transenella? sp.

Tresus nuttalli (Conrad)

Zirfaea pilsbryi Lowe

Barnacles:

Balanus gregarius (Conrad)?

M1935. Wunpost quadrangle.

Echinoids:

Astrodapsis spatiosus Kew

sp.

Dendraster sp.

Gastropods:

Bittium casmaliense Bartsch

Calicantharus cf. C. fortis forma angulata

(Arnold)

cf. C. humerosus (Gabb)
USGS loc.

M1935. kettlemanensis (Arnold)

Cancellaria cf. C. fernandoensis Arnold

Crepidula ef. C. nummaria Gould

cf. C. onyx Sowerby

Crucibulum (Dispotaea) n. sp.

Forreria belcheri (Hinds)

Margarites aff. $M$. pupillus (Gould)

Megasurcula n. sp. aff. M. wynoocheensis

(Weaver)

Mitrella sp.

Nassarius cf. $N$. californianus (Dall)

Neverita ef. $N$. recluziana (Deshayes)

Ocenebra cf. O. tethys (Nomland)

Sinum cf. S. scopulosum (Conrad)

Turritella vanvlecki Arnold

Pelecypods:

Cyclocardia californica (Dall)

Florimetis biangulata (Carpenter)

Glans n. sp. aff. G. radiata (Sowerby)

Glycymeris ef. G. grewinki Dall

Lyropecten terminus (Arnold)

Macoma nasuta (Conrad) secta (Conrad)

Ostrea atwoodi Gabb

Protothaca cf. P. lacinata hannibali (Howe) tenerrima (Carpenter)?

Sanguinolaria cf. S. nuttalli Conrad

Solen sp.

Spisula hemphilli (Dall)?

Tellina cf. T. aragonia Dall cf. T. lutea Wood

Trachycardium quadragenarium (Conrad)

Transenella tantilla (Gould)

Yoldia sp.

Barnacles:

Balanus gregarius (Conrad)

sp.

M2050. Adelaida quadrangle.

Gastropods:

Bittium casmaliense Bartsch?

Calicantharus cf. C. fortis (Carpenter)

Calyptraea filosa (Gabb)

Clavus coalingensis (Arnold)

Crassispira n. sp.? aff. C. martinensis Dall

Crepidula adunca Sowerby

Margarites of. $M$. condoni Dall

Nassarius aff. N. californianus (Conrad)

Polinices lewisi (Gould)

Turritella cooperi Carpenter gonostoma hemphilli Merriam

Pelecypods:

Cryptomya californica Conrad

Florimetis biangulata (Carpenter)

Glycymeris sp.

Lyropecten estrellanus (Conrad)

Macoma indentata Carpenter? nasuta (Conrad)

Modiolus sp.

Protothaca sp.

Solen perrini Clark?

Spisula sp.

M2276. Nattrass Valley quadrangle.

Gastropods: 
USGS loc. M2276.

Calicantharus sp.

Calliostoma coalingense Arnold

Calyptraea sp.

Nassarius sp.

Nucella etchegoinensis (Arnold)

Turritella gonostoma hemphilli Merriam

Pelecypods:

Lyropecten cf. L. cerrosensis (Gabb)

Nuculana cf. $N$. taphria (Dall)

Ostrea atwoodi Gabb

Panopea abrupta (Conrad)

Patinopecten sp.

Protothaca cf. P. lacinata hannibali (Howe)

Saxidomus sp.

Trachycardium quadrangenarium (Conrad)

Barnacle:

Balanus gregarius (Conrad)

M2278. Monarch Peak quadrangle.

Gastropods:

Bittium sp.

Calliostoma etchegoinense Nomland

Calyptraea filosa (Gabb)

Cancellaria cf. C. fernandoensis Arnold

Crassispira n. sp.? aff. C. martinensis Dall

Crepidula cf. C. adunca Sowerby

Mitrella sp.

Nassarius grammatus (Dall)? salinasensis Addicott

Neverita recluziana (Deshayes)

Turricula aff. T. piercei (Arnold)

Turritella n. sp. [T. broderipiana stock]

Pelecypods:

Cryptomya californica Conrad

Lucinisca n. sp. aff. L. nuttalli (Conrad)

Macoma sp.

Ostrea atwoodi Gabb

M2280. Pinalito Canyon quadrangle.

Gastropods:

Calicantharus kettlemanensis (Arnold)

Nassarius cf. N. grammatus (Dall)

Pelecypods:

Anadara cf. A. trilineata forma canalis (Conrad)

Hinnites giganteus (Gray)

Lyropecten terminus (Arnold)

Ostrea atwoodi Gabb

Patinopecten lohri (Hertlein)

Pododesmus cepio (Gray)

Spisula sp.

Barnacle:

Balanus gregarius (Conrad)

M3241. Bryson quadrangle.

Gastropods:

Calyptraea sp.

Cancellaria rapa perrini Carson.

(Euclia) n. sp.? aff. C. (E.) oregonensis (Conrad)

Crassispira? sp.

Crepidula sp.

n. sp. aff. C. aculeata (Gmelin)

Nassarius? sp.

Neverita cf. $N$. alta Dall

recluziana (Deshayes)

Turritella cooperi Carpenter
USGS loc.

M3241.

Pelecypods:

Clinocardium? aff. C. hannibali Keen

Dosinia cf. $D$. ponderosa Gray

Gari sp.

Lucinisca n. sp. aff. L. nuttalli (Conrad)

Lyropecten terminus (Arnold)

Macoma nasuta (Conrad)

Ostrea sp.

Protothaca tenerrima (Carpenter)

Saccella? sp.

Spisula sp.

Tellina cf. T. idae Dall

sp.

M3999. Ranchito Canyon quadrangle.

Echinoid:

Astrodapsis arnoldi Pack

Gastropods:

Forreria sp.

Trochita sp.

Pelecypods:

Anadara camulosensis (Osmont)

Crenomytilus? cf. C. coalingensis (Arnold)

Florimetis biangulata (Carpenter)

Lucinisca n. sp. aff. L. nuttalli (Conrad)

Lyropecten cf. L. terminus' (Arnold)

Macoma cf. M. nasuta (Conrad)

Modiolus sp.

Ostrea atwoodi Gabb

Protothaca tenerrima (Carpenter) sp.

Solen cf. S. perrini Clark

Trachycardium?

M4000. Ranchito Canyon quadrangle.

Echinoids:

Astrodapsis cf. A. fernandoensis Pack sp.

Gastropods:

Forreria belcheri (Hinds)

cf. F. coalingensis (Arnold)

Ocenebra sp.

Pelecypods:

Anadara cf. A. trilineata (Conrad)

Florimetis biangulata (Carpenter)

Lucinisca sp.

Modiolus sp.

Ostrea atwoodi Gabb

Panopea cf. P. abrupta (Conrad)

Protothaca tenerrima (Carpenter)

Semele sp.

Siliqua sp.

Solen sp.

M4006. Lonoak quadrangle.

Brachiopod:

Discinisca sp.

Gastropods:

Calicantharus cf. C. fortis (Carpenter)

Calyptraea sp.

Forreria cf. F. belcheri (Hinds)

Kelletia kelleti (Forbes)

Nassarius coalingensis (Arnold)

sp.

Ocenebra? 
USGS loc.

M4006. Pelecypods:

Clinocardium cf. C. meekianum (Gabb)

Cryptomya sp.

Florimetis sp.

Lucinisca n. sp. aff. L. nuttalli (Conrad)

Lyropecten terminus (Arnold)

Patinopecten cf. P. lohri (Hertlein)

Barnacle: Siliqua sp.

Balanus?

AGE AND CONDITIONS OF DEPOSITION

Fossils in the Pancho Rico Formation indicate a Pliocene age. According to W. O. Addicott (in Durham and Addicott, 1964, p. E5), the moderately large fauna of fossil mollusks and echinoids in the Pancho Rico Formation is indicative of Pliocene age, in the generally accepted Pacific Coast provincial chronology (Durham, 1954, p. 24). Some species in the Pancho Rico considered characteristic of the Pliocene are Turritella vanvlecki Arnold, Bittium casmaliense Bartsch, Calicantharus kettlemanensis (Arnold), Nassarius coalingensis (Arnold), Nassarius grammatus (Dall) [N. moranianus (Martin), of authors], Clavus coalingensis (Arnold), Crenomytilus cf. C. coalingensis (Arnold), Ostrea atwoodi Gabb, Patinopecten lohri (Hertlein), and Lyropecten terminus (Conrad). If the sequence of Pliocene beds of the Coalinga district, California, described by Nomland (1917, p. 211-213) is taken as a provincial standard of reference and used as the basis of a twofold chronostratigraphic division of the Pliocene (W. O. Addicott, in Durham and Addicott, 1965, p. A16-A17), then much or all of the Pancho Rico would be early Pliocene in age. Following this twofold division, species in the Pancho Rico considered to be early Pliocene guides are Calicantharus kettlemanensis, Ostrea atwoodi, and Patinopecten lohri. Further evidence of probable early Pliocene age is the stratigraphic overlap of the echinoid genera Astrodapsis (late Miocene to early Pliocene) and Dendraster (early Pljocene to Holocene) (W. O. Addicott, written commun., 1971).

Foraminifers in the Pancho Rico Formation are mainly long-ranging forms of little value in age determinations.

Fossils in the Pancho Rico Formation provide ample evidence of the marine origin of most of the unit and commonly suggest a shallow-water nearshore marine environment (Durham and Addicott, 1965, p. A18). The faunas at localities M3998-M4000 in the Ranchito Canyon quadrangle, for example, indicate the littoral zone or uppermost part of the inner sublittoral zone, and a warm temperate or marginally subtropical marine climate; the fauna at locality M4006 in the
Lonoak quadrangle represents shallow water-probably less than 15 fathoms-of normal marine salinity (W. O. Addicott, written commun., 1969). The faunas at localities M902 and M981 in the Reliz Canyon quadrangle are exceptions to the general shallow-water aspect of the Pancho Rico fauna because they include some exclusively moderate-depth taxa, such as Turcica sp. and Terrebratalia arnoldi Hertlein and Grant (W. O. Addicott, in Durham and Addicott, 1965, p. A18). According to Patsy B. Smith (written communs., 1960, 1963), foraminifers from the Pancho Rico at localities in the San Lucas and Valleton quadrangles indicate warm shallow water less than 50 meters deep. The foraminiferal fauna at locality M902 in Reliz Canyon is characteristic of an upper to middle neritic biofacies (R. L. Pierce, written commun., 1968).

\section{TERTIARY AND QUATERNARY(?) SYSTEMS}

\section{PLIOCENE AND PLEISTOCENE(?) SERIES}

\section{PASO ROBLES FORMATION}

\section{NOMENCLATURE}

The term "Paso Robles Formation" applies to strata that accumulated after withdrawal of the Tertiary sea and before deposition of sediments classed as alluvium. Fairbanks (1898, p. 565) used the term for "a very extensive series of beds having apparently a freshwater origin," and added that the beds are "characteristically exposed about the town of Paso Robles, hence the designation."

\section{DISTRIBUTION AND THICKNESS}

The distribution of the Paso Robles Formation (pl. 1) suggests that at one time the unit covered most, if not all, of the southern Salinas Valley area. The principal exposures of the formation are in the southeastern part of the area and in the upper San Antonio River valley. The unit also crops out in patches or ridgetops east of the Salinas River and in the hills west of the river from north of the Arroyo Seco southeastward across Quinado Canyon.

The thickness of the Paso Robles Formation varies considerably, largely because the upper part of the unit has been lost by erosion. It is about 1,400 feet west of King City and near Bradley, it is at least 1,000 feet east of the San Ardo oil field, but is no greater than 400-500 feet east of King City and in the San Antonio River valley. Thin remnants of the formation cap high hills and ridges at many places. Estimation of the subsurface thickness of the Paso Robles is hampered by the difficulty is recognizing either the top or the base of the formation in well records. 


\section{LITHOLOGY}

The Paso Robles Formation is mainly sandstone and conglomerate, with some mudstone and limestone, and minor amounts of gypsum and woody lignite. Conglomerate marks the base of the formation at most places and is common throughout the unit. The Paso Robles generally is best exposed in roadcuts and in the banks of large streams, because most rocks in the formation are friable and fail to form bold outcrops. Only limestone and certain well-cemented conglomerate beds have prominent outcrops on hillsides.

Conglomerate in the Paso Robles Formation forms beds or units a few feet to several tens of feet thick that commonly have channels and cross-strata (fig. 35 ). The conglomerate contains clasts as large as boulders at a few places, although generally the largest clasts are pebbles or small cobbles; the clasts range from angular to rounded but are mainly rounded. Composition of the conglomerate varies considerably from place to place with little obvious pattern. In the northern part of the mapped area, the pebbles and larger clasts are mainly porcelanite and chert derived from the Monterey Formation; south of the San Ardo oil field and at places around the San Antonio River valley, the clasts are of a wide variety of rocks, including porcelanite, chert, granitic and metamorphic rocks from the basement complex, volcanic rocks, wellcemented sandstone, and debris from the Franciscan Formation. The conglomerate matrix which is mainly yellowish gray, greenish gray, and very pale orange, generally is poorly sorted silt, fine- to medium-grained sand, and scattered coarser grains. The conglomerate ranges from friable and moderately porous to well indurated and dense. The more friable conglomerate is mainly noncalcareous, the better indurated rock generally calcareous. Conglomerate near the base of the formation in the northem part of the area has a matrix of opaline silica; the rock is so firmly cemented that it breaks across rather than around the clasts.

Sandstone in the Paso Robles Formation ranges from fine to coarse grained and generally is poorly sorted. It is interbedded with, and grades into, conglomerate, and it commonly contains scattered granules, pebbles, and cobbles. The sandstone is mainly massive or poorly bedded and has conspicuous crossstrata and channels; it generally weathers to yellowish gray and very pale orange. The rock commonly is friable and noncalcareous, but it is slightly calcareous locally, and a few beds are firmly cemented by calcite. The sand grains, which range from angular to subrounded, are chiefly quartz and feldspar, although grains of chert, porcelanite, and mudstone are conspicuous locally.
Mudstone in the Paso Robles Formation contains fine to very coarse sand grains in an abundant matrix of very fine grained sand, silt, and clay; locally, it is pebbly. The mudstone grades into sandstone and at some places contains lenses and irregular pods of sand. The rock is mainly massive and has a hackly fracture. It is chiefly noncalcareous but is locally moderately to highly calcareous. Weathered mudstone is very pale orange, yellowish gray, and grayish orange.

Limestone is widespread in the Paso Robles Formation in the southern part of the mapped area and forms conspicuous outcrops (fig. 36). It occurs in beds or units 1-5 feet thick, is generally associated with sandstone, and commonly contains scattered sand grains. The rock has vugs and cracks lined with calcite and locally it contains former voids lined with opal and filled with chalcedony. The limestone weathers to very pale orange, gray, and pinkish gray.

Woody lignite in the Paso Robles Formation crops out in railroad cuts north of Bradley in the Wunpost quadrangle and in cuts along an oil pipeline on Camp Roberts in the Adelaida quadrangle. The material, in beds 2-4 inches thick, is brownish gray, flaky, and friable. Lenticular bodies of gypsum as thick as 6 feet (fig. 45) are intercalated in friable mudstone of the Paso Robles near the northeastern corner of the mapped area.

\section{STRATIGRAPHIC RELATIONS}

The lower contact of the Paso Robles Formation generally is at the base of the stratigraphically lowest conglomerate bed above fossiliferous Miocene or Pliocene marine rocks. It represents the beginning of nonmarine deposition following the last withdrawal of the Tertiary sea from the mapped area, and it is not everywhere at the same stratigraphic horizon. The Paso Robles overlies the Pancho Rico Formation conformably in the northern part of the area, but it overlies the Pancho Rico with a slight angular discordance farther south near the San Antonio River, where it also lies unconformably on older beds (figs. 38, 39). The Paso Robles conformably overlies the Santa Margarita Formation at some places in the southern part of the area, and unconformably overlies the Santa Margarita and older rocks at other places. The variety of stratigraphic relations exhibited by the Paso Robles probably results from including in the formation beds that were deposited over a wide area under various conditions and during a long period of time that included one or more episodes of tectonic activity.

Part of the Paso Robles Formation may intertongue with, or grade laterally into, the Pancho Rico Formation, for the lower part of the Paso Robles in the southern part of the mapped area seems to occupy the 


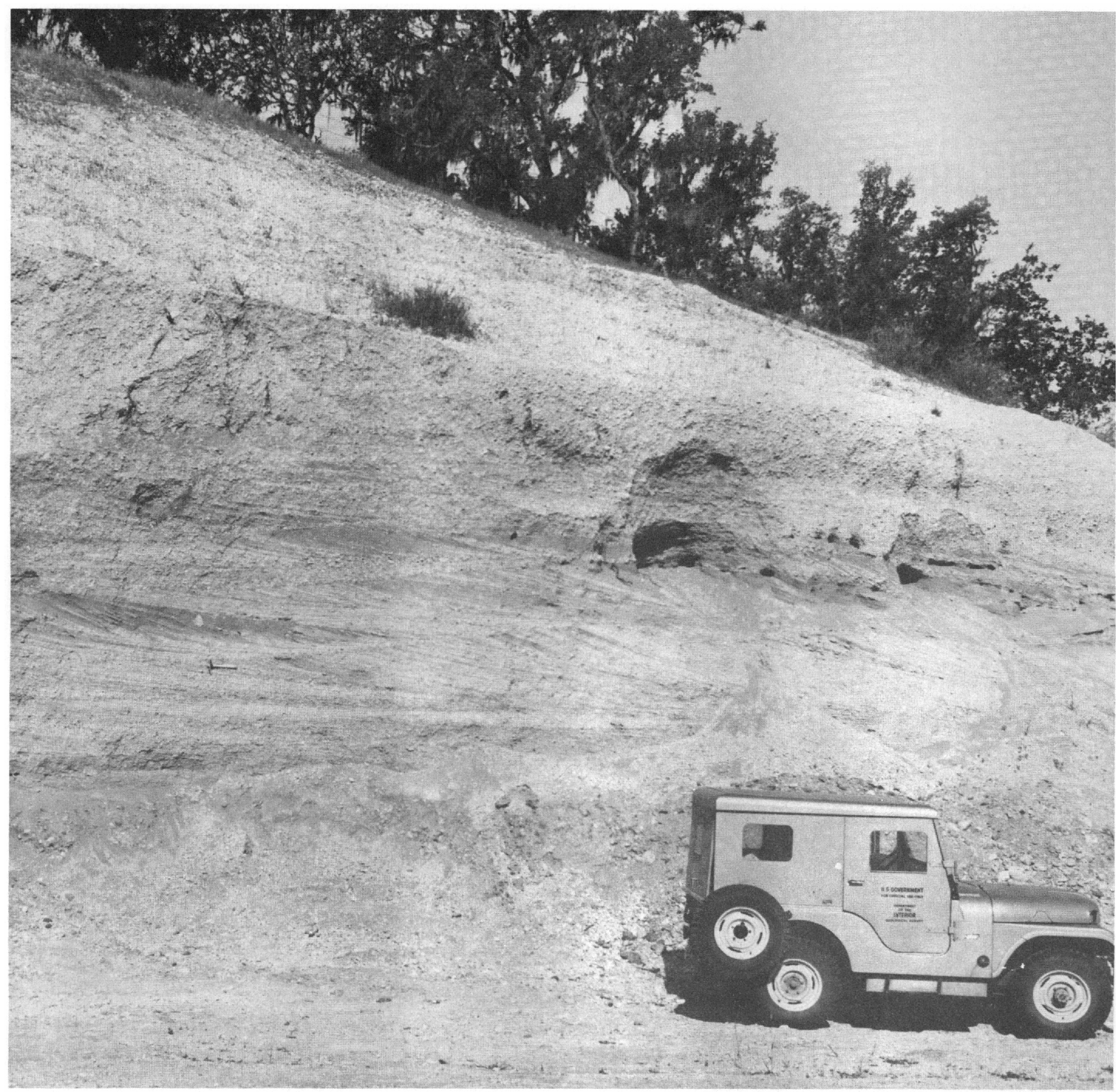

Figure 35-Cross-stratified pebble conglomerate in the Paso Robles Formation in a quarry face near the southeast corner of the Templeton quadrangle. Nearly all the pebbles are from the Monterey Formation.

stratigraphic position that the Pancho Rico holds farther north. Intertonguing of the two formations generally is difficult to demonstrate, but an apparent example of intertonguing of nonmarine Paso Robles and marine Pliocene beds is found near the southeast corner of the Templeton quadrangle. J. S. Galehouse and students from San Francisco State College found Pliocene marine fossils there in 1971 in sandy con- glomerate beds that overlie the cross-stratified conglomerate shown in the photograph (fig. 35) made in 1964. The quarry face was later cut farther back into the hill, exposing stratigraphically higher beds that contain the fossils. According to W. O. Addicott (written commun., 1971), the assemblage from the locality (USGS loc. M4621 (field No. G-55), on face of gravel quarry near road, about $2,900 \mathrm{ft} \mathrm{N}$., $150 \mathrm{ft}$ 


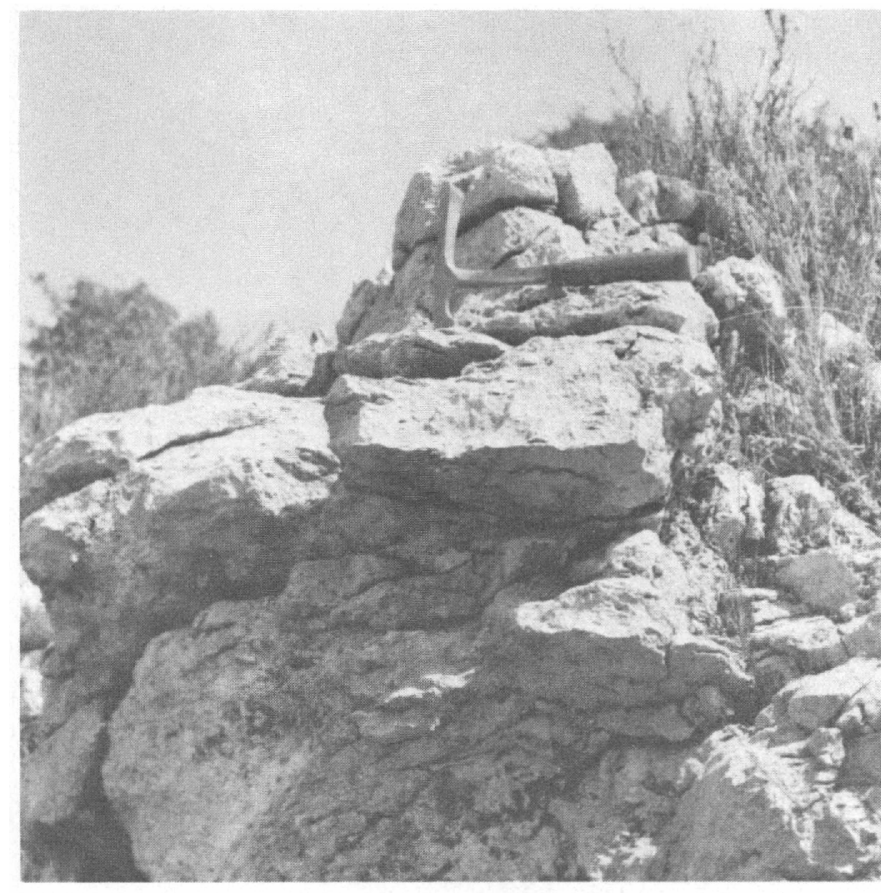

FiguRe 36.-Massive limestone in the Paso Robles Formation north of the San Antonio River, Hames Valley quadrangle.

W. of SE. cor. Templeton quadrangle, Asuncion land grant. Fossils: brachiopods, pelecypods, barnacles. Age: Pliocene. Collectors: J. S. Galehouse, 1971; W. O. Addicott, J. S. Galehouse, and D. L. Durham, 1971) represents a very shallow water marine environment and "surely has to be autochthonous;" it contains the following fossils (identified by W. O. Addicott) :

Brachiopod: Terebratalia cf. T. arnoldi Hertlein and Grant Pelecypods:

Crassostrea titan (Conrad) (one specimen, reworked) Hinnites multirugosus (Gale)

Nettastomella rostrata (Valenciennes)

Ostrea atwoodi Gabb (one specimen)

Barnacle: vespertina sequens Arnold (extremely abundant)

Balanus sp. (external plates)

Differences between this assemblage and assemblages in the Pancho Rico Formation farther north may indicate an incursion of an arm of the sea that extended to the locality from the west or southwest and had no direct connection with the body of water in which the Pancho Rico Formation accumulated.

\section{FOSSILS}

Indigenous fossils are scarce in the Paso Robles Formation. Stanton (1931, p. 46) reported small freshwater gastropods in the Paso Robles about 7 miles east of the town of Paso Robles, and Taliaferro found "small fresh-water gastropods" near the mouth of Lowes Canyon in the San Miguel quadrangle (NW1/4-
SE $1 / 4$ sec. 14, T. 25 S., R. 12 E.) (N. L. Taliaferro, unpub. field notes dated May 15, 1935). Bell (1940, p. 39) noted fresh-water ostracodes in limestone of the Paso Robles exposed in a bluff north of Bradley, and Bramlette found "freshwater lime with diatoms" near the base of the Paso Robles west of Indian Valley in the Valleton quadrangle $(400 \mathrm{ft} \mathrm{N}, 2,200 \mathrm{ft} \mathrm{W}$. of SE cor. sec. 4, T. 23 S., R 12 E.) (M. N. Bramlette, unpub. field notes dated Feb. 26, 1944). H. E. Clifton discovered a bone in limestone of the Paso Robles exposed along an oil pipeline on Camp Roberts in the Adelaida quadrangle; C. A. Repenning (oral commun., 1964) identified the bone as from a bird, probably a wading bird. Foraminifers from the Paso Robles in the Reliz Canyon quadrangle represent the Miocene Luisian Stage (Patsy B. Smith, written commun., 1960 ), but they are obviously reworked from the Sandholdt Member of the Monterey Formation.

\section{AGE AND CONDITIONS OF DEPOSITION}

Direct fossil evidence concerning the age of the Paso Robles Formation is lacking in the mapped area, except for the Pliocene fossils in a marine tongue included in the formation near the southeast corner of the Templeton quadrangle. The Paso Robles at some places conformably overlies the Pancho Rico Formation, which contains fossils of Pliocene age, and at other places conformably overlies the Santa Margarita Formation, which contains fossils of late Miocene age; the formation unconformably underlies Quaternary alluvium. The stratigraphic position of the Paso Robles Formation indicates Pliocene and Pleistocene(?) age for the unit, although where it conformably overlies the Santa Margarita it could be as old as late Miocene.

Crude bedding, poor sorting, cross-stratification, and channeling in parts of the Paso Robles Formation suggest that the unit is nonmarine and largely fluviatile in origin; the scarcity of fossils in the Paso Robles and the similarity of the formation to alluvial sediments in modern streams support this view. Galehouse (1967) studied pebble and heavy-mineral distribution and current indicators in the Paso Robles and concluded (p. 972-973) that the formation in the southeastern part of the mapped area was deposited by streams that flowed southeastward from the Santa Lucia Range and northward from the La Panza Range into a trunk stream that flowed eastward near the modern Estrella River valley. He also concluded (p. 973) that deposition of the Paso Robles ended with a period of interior drainage "which may be represented by lake beds in the upper portion of the Paso Robles Formation." Taliaferro (1943b, p. 461) con- 
sidered the limestone in the Paso Robles to be lacustrine in origin. Carbon and oxygen isotope analysis by Irving Friedman, of a sample of the limestone collected by $\mathrm{K}$. J. Murata in the Hames Valley quadrangle (NW $1 / 4$ sec. 34 , T. 23 S., R. 9 E.), indicates that the rock "is not of fresh water origin, although it probably originated in brackish water with much terrestrial carbon" (Irving Friedman, written commun. to K. J. Murata, 1967). Bedded gypsum in the Paso Robles northeast of King City indicates the existence of a lake there during deposition of the formation; woody lignite in the formation suggests local swampy conditions.

\section{QUATERNARY SYSTEM}

\section{PLEISTOCENE AND HOLOCENE SERIES}

\section{ALLUVIUM}

Sediments younger than the Paso Robles Formation are classed as alluvium and include: (a) old alluvium associated with old land surfaces in the hills; (b) old alluvium in valleys and lowland areas; (c) modern alluvium in streambeds; (d) debris-flow material; and (e) dune sand. Alluvium covers most valley bottoms and terraces along major streams in the mapped area. Gravel and patches of alluvium on ridges and hilltops are evidence of a former widespread alluvial blanket. The exposed thickness of older alluvium in bluffs along the Salinas River is at least 60-80 feet; the thickness of alluvium is unknown in most valleys because the material is difficult to distinguish from the Paso Robles Formation in well records.

The alluvium consists mainly of gravel, sand, and silt; it generally is unconsolidated, but some older alluvium beds are well indurated. The gravel is sandy, poorly sorted, and ranges in color from yellowish gray and pale yellowish brown to dark reddish brown. It is mainly massive or crudely bedded and commonly includes channels and cross-strata. The larger clasts are of a variety of rocks that obviously represent widely different source areas. Sand and silt units are interbedded with the gravel and locally make up the bulk of the alluvium. The sand and silt commonly are pale yellowish orange, massive, and friable; they are calcareous locally and contain caliche or calichelike material at some places.

Alluvium unconformably overlies the Paso Robles Formation and older rocks. It is easily distinguished from the Paso Robles where the Paso Robles is deformed and both units are well exposed; where the Paso Robles is flat lying and where exposures are poor, the distinction is difficult or arbitrary. Some flat areas underlain by alluviumlike sediments, for example, are mapped as alluvium, whereas nearby rounded hills of similar material are assigned to the Paso Robles; the only practical distinction at such places is physiographic.

Fossils are scarce in the alluvium. In 1966 workmen uncovered the skull of a mammoth in terrace gravels about 40 feet above the Salinas River just east of San Miguel. C. A. Repenning studied a tooth from the skull and stated that "the specimen appears to be an Imperial Mammoth, Mammuthus imperator (Leidy)" (C. A. Repenning, written commun., 1966).

The alluvium is mainly of fluviatile origin; exceptions are dune deposits, mudflow debris, and lacustrine sediments. Dunes are especially obvious in the lowland area between King City and San Ardo, where strong winds are common. Debis-flow material that debouched from the hills just south of Paraiso Springs covers more than a square mile. Lacustrine sediments occur locally in ephemeral lakes and accumulate in reservoirs behind the Nacimiento and San Antonio Dams.

The alluvium is younger than the Paso Robles Formation, most probably late Pleistocene and Holocene in age. If the mammoth from near San Miguel is Mammuthus imperator (Leidy), as it seems, then the sediments that contained it probably are of late Pleistocene (Rancholabrean mammal) age although it is not possible to rule out a middle Pleistocene (Irvingtonian mammal) age (C. A. Repenning, written commun., 1966).

\section{STRUCTURE}

\section{GENERAL FEATURES}

The southern Salinas Valley area lies mainly on the Salinian block (fig. 37), a structural element of the Coast Ranges that is characterized by a basement of granitic and high-grade metamorphic rocks (Compton, $1966 \mathrm{a}$, p. 277); the basement rocks of the Salinian block contrast markedly with rocks of the Franciscan Formation in adjacent regions. The San Andreas fault zone borders the Salinian block along the northeast side, and a complex fault system borders the block along the southwest side. In the mapped area, the Jolon-Rinconada fault zone apparently forms the southwest border of the block; the basement complex of the Salinian block crops out and has been identified in wells northeast of the zone, but none is known in the mapped area southwest of the zone, where the oldest rocks that crop out or that have been recognized in wells belong to the unnamed formation of Cretaceous and Paleocene age. Direct evidence concerning rocks beneath the unnamed formation is lacking, but gravity data suggest that granitic rocks are absent southwest of the Jolon-Rinconada fault zone from the Williams Hill quadrangle to the south edge 


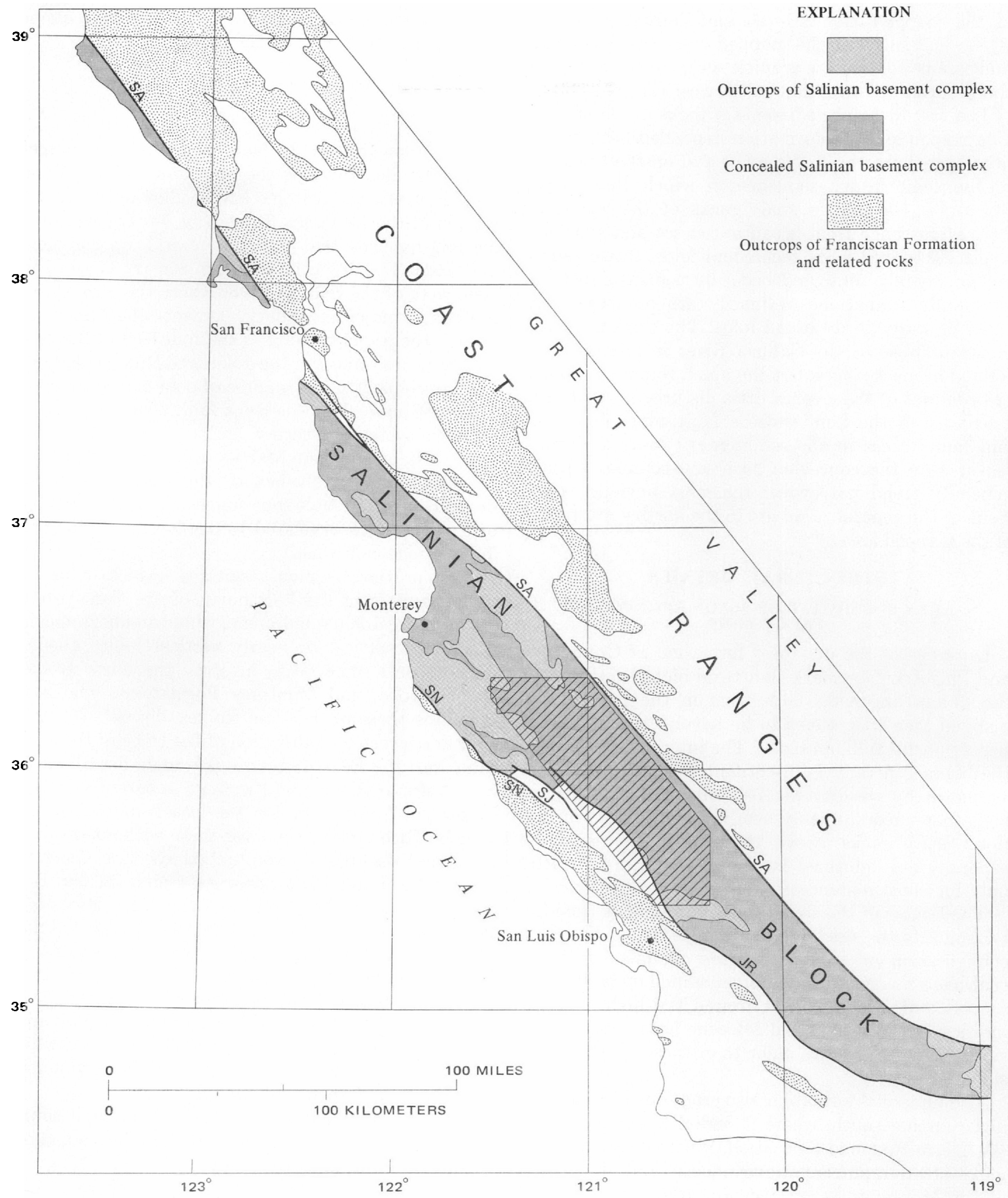

FIGURE 37.-Relation of the southern Salinas Valley area (crosshatched) to the Salinian block. Geology adapted from U.S. Geological Survey and California Division of Mines and Geology (1966). Abbreviations: JR, Jolon-Rinconada fault zone; SA, San Andreas fault zone; SJ, Sam Jones fault zone; SN, Sur-Nacimiento fault zone. 
of the mapped area (Burch and Durham, 1970, p. B13); just south of the mapped area, the Rinconada fault seems to separate granitic rocks on the east from the Franciscan Formation on the west (Hart, 1968).

The way in which sedimentary rocks in the mapped area responded to deformation depended both on the lithologic character of the rocks and on the thickness of the sedimentary sequence in which they occur. Structural features in shaly rocks of the Monterey Formation range from broad anticlines and synclines to closely spaced folds, recumbent folds, thrust faults, and intricately contorted beds; by contrast, rocks in the sandy formations ordinarily are no more than tilted or warped into broad folds. The thick sequence of strata west of the Salinas River is intensely deformed at most places, but the much thinner sequence of beds east of the river is little disturbed despite the proximity of the San Andreas fault zone. Fold axes and fault traces in the sedimentary rocks and relief features on the concealed basement-complex surface generally trend northwest; the most obvious exceptions to the general trend are in the northwestern part of the mapped area.

\section{STRUCTURAL DETAILS AREA SOUTHWEST OF JOLON-RINCONADA FAULT ZONE}

Outcrops of the unnamed formation of Cretaceous and Paleocene age mark structural highs southwest of the Jolon-Rinconada fault zone in the part of the mapped area that seems to lie beyond the southwest border of the Salinian block. The internal structure of the highs generally is discordant to their gross form as shown by the outcrop pattern of sandy Miocene beds that unconformably overlie the unnamed formation. Shaly rocks above the sandy Miocene beds generally are deformed into folds that can be traced only for short distances.

The largest of the structural highs extends from the Bryson into the Adelaida quadrangle; it has the gross configuration of a southeastward plunging anticline that has a margin considerably modified by faults. The sequence of Miocene beds around the high is asymmetrical because the basal Miocene beds on the north side of the feature are older than those on the south side.

The unnamed formation also crops out in structural highs farther south, where it underlies sandy beds of the Tierra Redonda Formation. Where poor exposures make stratigraphic relations unclear and shaly beds of the Monterey Formation appear to be in contact with the unnamed formation, the contact is interpreted to be a fault because of the absence of the sandstone beds that normally occur at the base of the
Miocene sedimentary sequence where the sequence unconformably overlies older rocks.

\section{JOLON-RINCONADA FAULT ZONE}

\section{DESCRIPTION}

The Jolon-Rinconada fault zone extends for more than 50 miles through the southern Salinas Valley area, from the San Antonio River valley to the western margin of the La Panza Range (fig. 1). It generally is marked by beds that dip steeply and are complexly deformed. The Jolon fault is the primary trace of the zone west of the Salinas River where the San Marcos fault is a major secondary element; the Rinconada fault is the principal trace of the zone east of the river. The projected traces of the Jolon and Rinconada faults seem to connect across an area of poor exposures south of Paso Robles. The Bee Rock fault zone (fig. 38) is a complex system of thrust faults exposed 1-4 miles southwest of the San Marcos and Jolon faults; the proximity and parallelism of the Bee Rock to the Jolon-Rinconada fault zone suggests that development of the Bee Rock is related to displacement along the Jolon-Rinconada zone.

The northwesternmost surface evidence of the Jolon fault is in the hills north of the San Antonio River in the Jolon quadrangle, where an anastomosing system of vertical or nearly vertical faults about a quarter of a mile wide involves the Paso Robles, Pancho Rico, and Monterey Formations. The beds, including those of the Paso Robles, dip $60^{\circ}-90^{\circ}$. Farther northwest the projection of the trace of the Jolon fault into the Bear Canyon quadrangle lies along the San Antonio River, but the fault apparently fails to follow the projection, for the basal contact of the Pancho Rico crosses the river there without displacement and outlines a steep-limbed syncline along the river. The Jolon fault apparently ends in the Bear Canyon quadrangle. The role of the Jolon-Rinconada fault zone as the southwest border of the Salinian block evidently is transferred in the Jolon quadrangle to the parallel Sam Jones fault zone (Burch, 1971, pl. 1), which is $4-5$ miles farther southwest (fig. 37 ). Most of the displacement along the Jolon fault may have been transferred to the parallel fault zone, which would account for failure of the Jolon fault to persist into the Bear Canyon quadrangle.

The next surface indication of the Jolon fault southeast of the Jolon quadrangle is in Tule Canyon, about 2 miles south of Lockwood in the Williams Hill quadrangle. The actual trace of the fault there is concealed, but the effect of the fault is obvious. Nearly flat beds of the Paso Rcbles Formation southwest of the fault unconformably overlie vertical beds of the 
Monterey Formation that are exposed in a branch of Tule Canyon. Steeply northeast-dipping beds of the Paso Robles crop out in a large roadcut northeast of the fault; the dip of the beds is greatest near the fault and flattens to the northeast. Evidence of the Jolon fault is lacking in the hills on both sides of Tule Canyon because the rocks there are poorly exposed; a spring near the head of the canyon may be related to the fault.

The projected trace of the Jolon fault southeast of Tule Canyon crosses low hills of the poorly exposed Paso Robles Formation for about 2 miles and trends along the alluvium-covered bottom of the San Antonio River valley for another $6 \frac{1}{2}$ miles. Farther southeast the fault apparently passes beneath the northeastdipping San Antonio fault. This interpretation of the relation of the San Antonio and Jolon faults is based on the concept of the Jolon fault as a throughgoing feature that separates unlike stratigraphic sequences. Beds on the upper plate of the San Antonio fault (fig. 39 ) belong to the stratigraphic sequence northeast of the Jolon fault, but they lie southeast of the projected trace of the Jolon fault (fig. 39) and overlie rocks that belong to the stratigraphic sequence southwest of the Jolon fault.

The Jolon fault is exposed south of the San Antonio River more or less continuously for about 17 miles. Just south of the river in the Tierra Redonda Mountain quadrangle, the fault is marked by a belt of crushed and contorted porcelaneous rocks in the Hames Member of the Monterey Formation; these severely deformed rocks are well exposed in cuts south of the San Antonio Dam. Near the Nacimiento River in the Bradley quadrangle, the fault trace is the contact between the Santa Margarita Formation and the Hames Member of the Monterey. Farther southeast in the northern part of the Adelaida quadrangle, it separates contemporaneous but unlike upper Miocene and Pliocene stratigraphic sequences. The Jolon fault, or a branch of it, appears to continue southeastward across an area of poor exposures to San Marcos Creek; south of the creek it forms the boundary between outcrops of basement complex and Miocene strata in the Adelaida and Paso Robles quadrangles. The trace of the fault is obscure across an area of poor exposures in and near the town of Paso Robles, where presumably it separates the Paso Robles and Monterey Formations, although perhaps the Paso Robles overlaps the Jolon fault to lie unconformably on the Monterey.

The Jolon-Rinconada fault zone south of the San Antonio River includes a major secondary trace, the San Marcos fault, which is nearly parallel to and a half mile to three-quarters of a mile southwest of the
Jolon fault. At most places, the trace of the San Marcos fault separates the Hames Member of the Monterey Formation on the northeast side from the Sandholdt Member of the Monterey on the southwest side. The trace is lost in the Templeton quadrangle in an area of poor exposures. Evidence of the fault is lacking east of the Salinas River, where an area of poorly exposed Paso Robles Formation lies across the projected trace. The fault may follow the Salinas River to Atascadero, where severely deformed beds suggest a major fault.

The projected trace of the Jolon fault southeast of Paso Robles appears to connect with the trace of the Rinconada fault east of the Salinas River. The Rinconada fault is well marked for about 5 miles in the Templeton quadrangle, where the trace separates severely deformed beds of the Hames Member of the Monterey Formation on the east side from the Paso Robles Formation and a narrow band of the Santa Margarita Formation on the west side. The Rinconada fault is also conspicuous farther south, where the Sandholdt Member of the Monterey crops out on the east side and the Santa Margarita and Paso Robles Formations crop out on the west side.

\section{BEE ROCK FAULT ZONE}

At most places the Jolon-Rinconada fault zone is flanked on the southwest side by easily deformed shaly rocks of the Monterey Formation that are thrust southwestward over less easily deformed sandy rocks of older formations. The Monterey beds are severely deformed at many places (fig. 40), but the underlying sandy rocks generally are no more than moderately tilted. Movement of the Monterey beds relative to the underlying sandy beds compensated for the difference in style of deformation of the shaly and sandy rocks. The movement was mainly on the Bee Rock fault zone, a system of bedding faults and thrust faults at and near the base of the Monterey. The name of the zone is from the Bee Rock fault (Durham, 1968, p. 43), a segment of the zone near the community of Bee Rock (fig. 54).

The magnitude of the displacement on the Bee Rock fault zone varies considerably. At some places, the Monterey and Tierra Redonda Formations are in normal stratigraphic order with little evidence of movement between them; at other places the Monterey has been thrust over much older rocks, and displacement amounts to hundreds or thousands of feet. Variation in the character of the Bee Rock fault zone suggests that the exposed trace of the zone shows different stages in development of a zone that originated as bedding faults and developed into a system of thrust faults that carried Monterey beds over an old land surface 


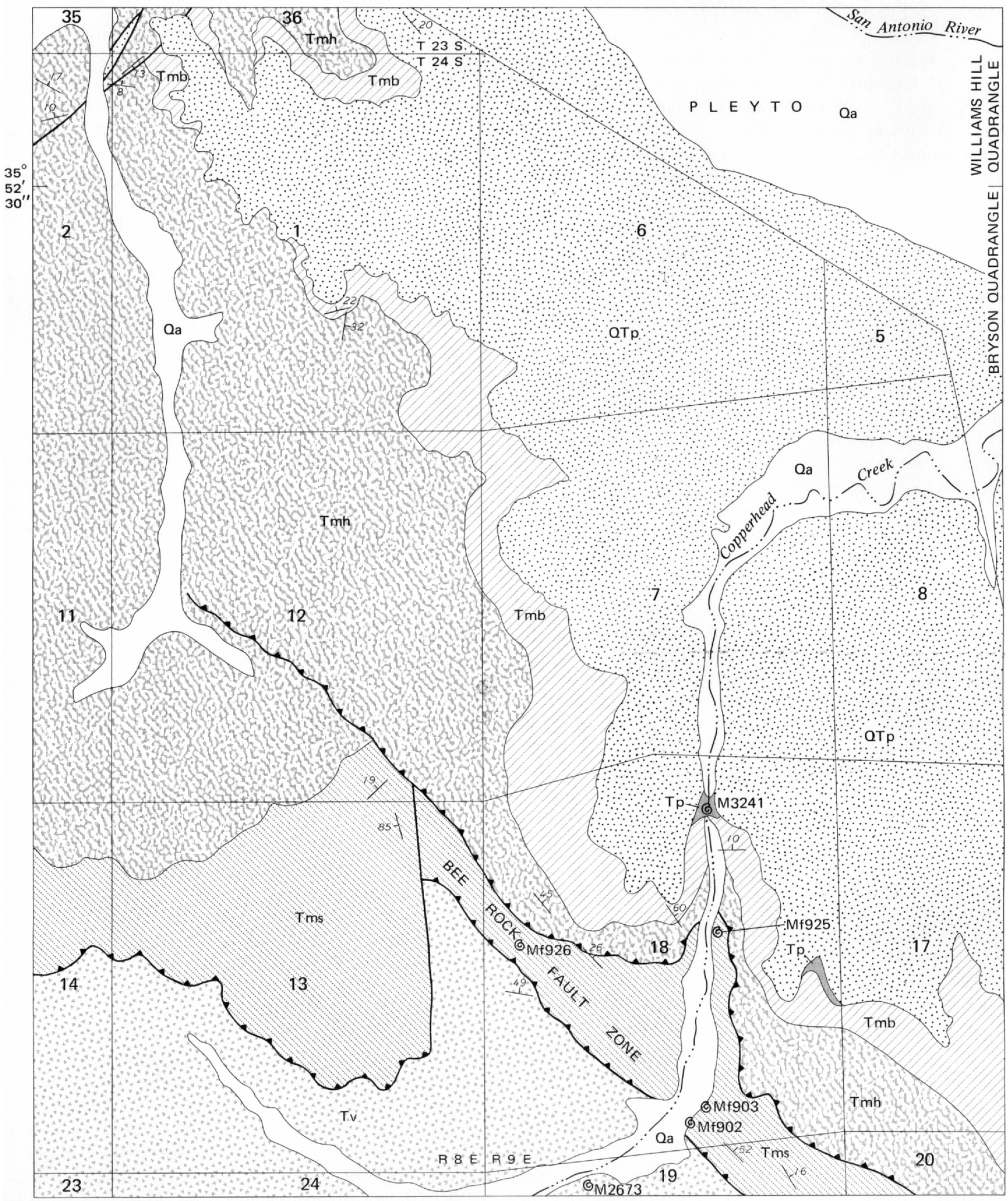

FIGURE 38.-Geologic sketch map of the Copperhead Creek area, Williams Hill and Bryson quadrangles. 


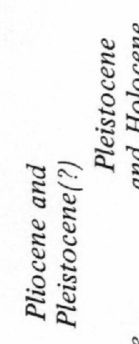

EXPLANATION
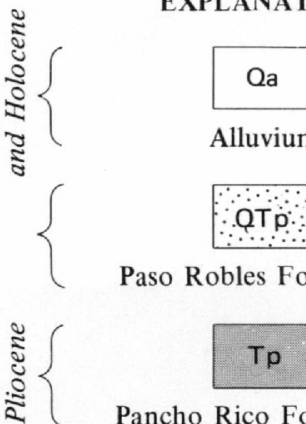

Qa

Alluvium \{

Paso Robles Formation

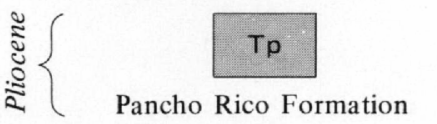

Pancho Rico Formation

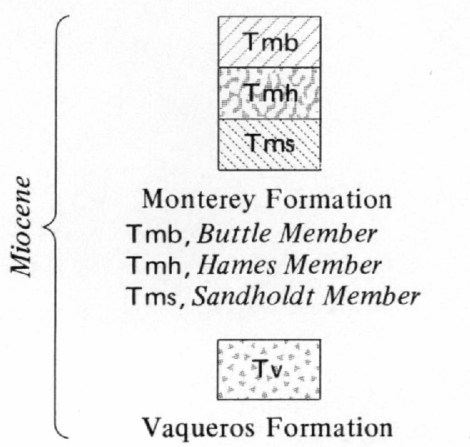

Contact

Gradational or approximately located

Fault

Approximately located

Thrust fault

Approximately located. Sawteeth on upper plate

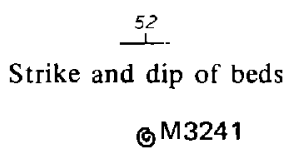

Fossil locality

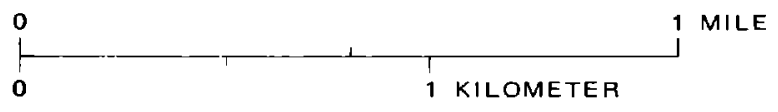

onto older rocks.

Evidence for the existence of the Bee Rock fault zone generally either is: (a) local omission of part of the normal stratigraphic sequence, (b) contrast in degree of deformation of the Monterey Formation and the underlying sandy beds, or (c) abrupt change in thickness of the sandstone unit exposed beneath the Monterey. An example of omission of beds along the zone is found near Copperhead Creek in the Bryson quadrangle (fig. 38), where the upper and lower contacts of the Sandholdt Member of the Monterey are intepreted as elements of the Bee Rock fault zone. This interpretation accounts for differences in foraminiferal faunas near the base of the Sandholdt; the lower part of the Sandholdt at Copperhead Creek contains foraminifers of the Saucesian Stage (locs. Mf902, Mf903, Mf926); farther west the lower part of the unit contains foraminifers of the Relizian Stage (locs. Mf1473, Mf1474, Mf1475). It also accounts for the extraordinary thinness of the Hames Member of the Monterey along Copperhead Creek, where the Buttle Member of the Monterey, which is latest Miocene in age, lies near Sandholdt beds that contain foraminifers of the middle Miocene lower Luisian Stage (loc. Mf925).

An example of contrast in the degree of deformation of the Monterey Formation and the underlying Tierra Redonda Formation across the Bee Rock fault zone is displayed just north of the Nacimiento Dam in the Tierra Redonda Mountain quadrangle, where shaly beds above the zone are severely deformed (fig. 40), and underlying sandy beds are only moderately tilted. The fault zone there is just above the base of the Sandholdt Member. An example of abrupt change in thickness of sandy beds exposed beneath the fault zone is displayed about 1 mile south of the Nacimiento River in the Adelaida quadrangle, where the zone truncates a cross fault. The fault zone there is at the base of the Sandholdt, and the exposed Tierra Redonda Formation is much thinner on the southeast side of the cross fault than it is on the northwest side.

The character of the Bee Rock fault zone is well displayed near the community of Bee Rock (fig. 41). Near the base of the Sandholdt Member of the Monterey Formation beds, exposed in roadcuts are crushed, broken, and moderately contorted, in contrast to nearly undeformed sandstone beds in the Tierra Redonda Formation beneath. Beds in the Sandholdt, 75-100 feet above the base of the member, are also crushed and are thrust along an element of the Bee Rock zone (fig. 42). Evidence of large displacement at the lower contact of the Sandholdt near Bee Rock is equivocal, but evidence of considerable displacement spread through a zone in the lower part of the Sandholdt seems clear.

The Bee Rock fault zone is conspicuous southeast of the community of Bee Rock, where the Sandholt Member of the Monterey Formation above the zone overlies the Vaqueros Formation and the older unnamed formation (fig. 41); the zone also truncates faults that displace the Vaqueros and older rocks. Evidence that the contact between the Sandholdt and older rocks is a fault there rather than an unconformity includes: (a) more severe deformation of beds 


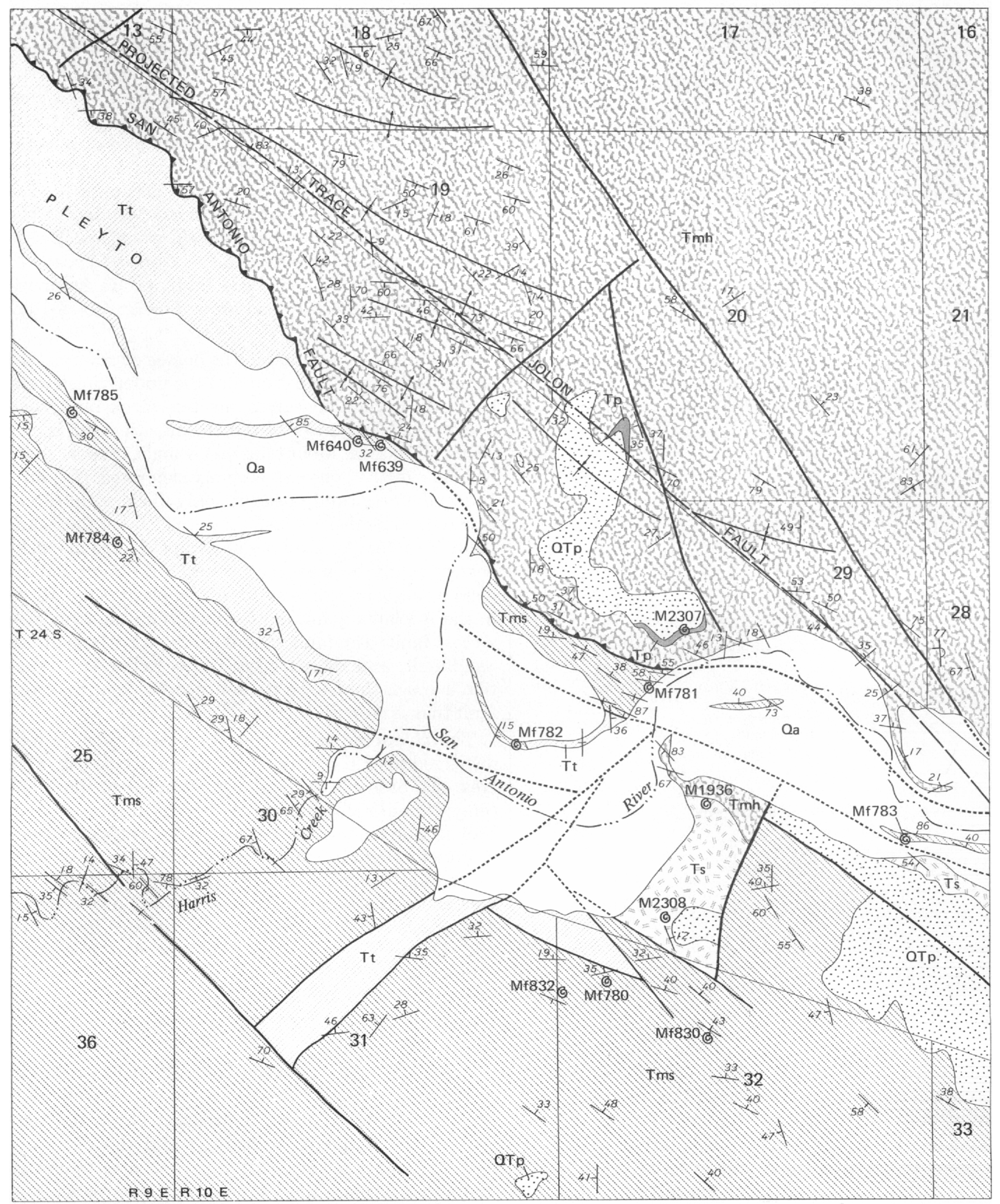

Figure 39.-Geologic sketch map of the lower San Antonio River area, Tierra Redonda Mountain quadrangle. 


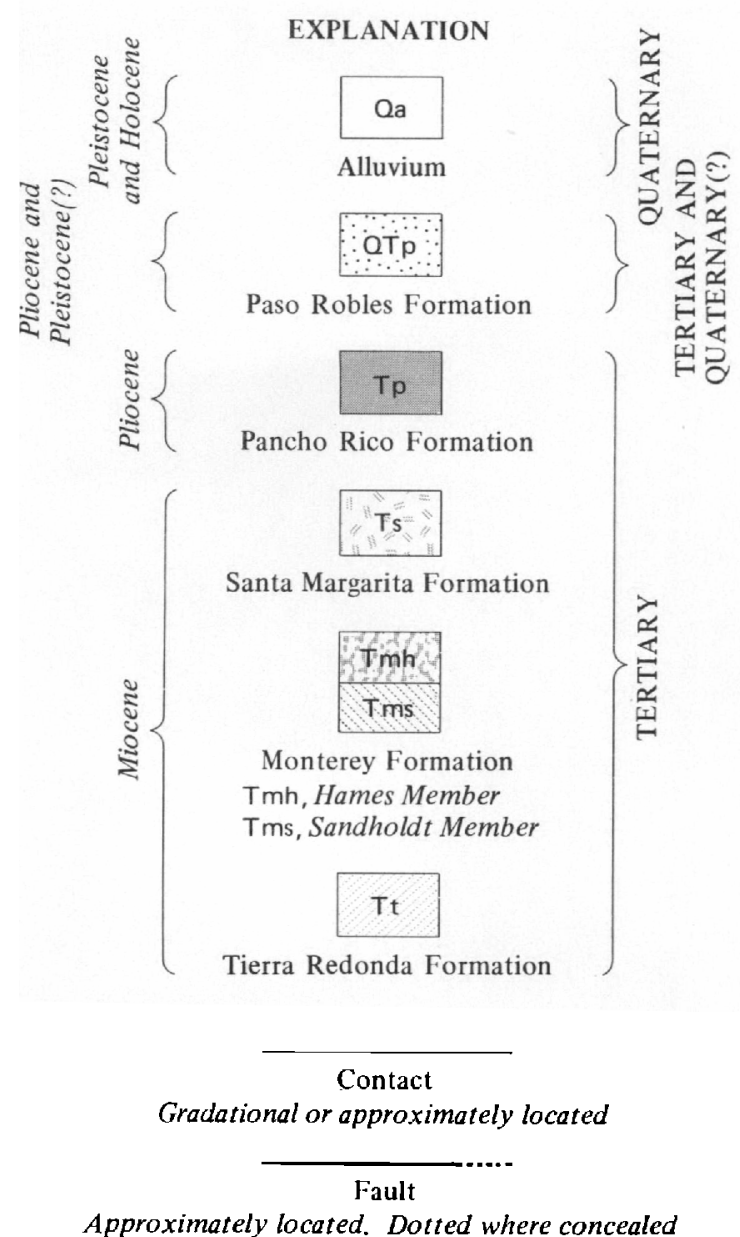

Approximately located. Dotted where concealed

Thrust fault

Approximately located. Sawteeth on upper plate. Dotted where concealed

Projected trace of Jolon fault beneath upper plate of San Antonio fault

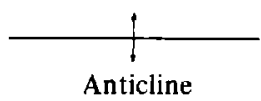

Showing crestline; approximately located

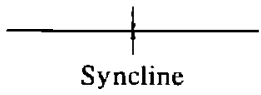

Showing troughline; approximately located

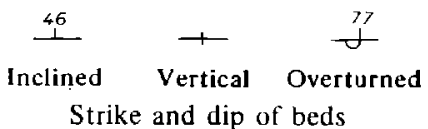

(6) M1936

Fossil locality

0

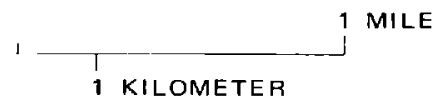

above the contact than below it, and (b) absence of sandy beds at the base of the Miocene stratigraphic sequence. Foraminifers just above the contact indicate stages that range from Saucesian (locs. Mf893, Mf1491) to lower Luisian (loc. Mf853).

\section{DISPLACEMENT}

The contrast between rocks on the east and west sides of the Jolon-Rinconada fault zone indicates two distinctly different episodes of displacement: (a) a Late Cretaceous or early Tertiary episode of crustal shortening perpendicular to the continental margin, and (b) a late Tertiary or early Quaternary episode of right-lateral strike-slip displacement more nearly parallel to the continental margin. If the hypothesis (Page, 1969) is correct that the southwest edge of the Salinian block represents the continental margin along which relatively eastward-moving oceanic crust and suprajacent rocks underthrust the continent, and if in the mapped area (from the Williams Hill quadrangle southeastward) the Jolon-Rinconada fault zone marks the southwest margin of the Salinian block, as indicated by evidence from outcrops, wells, and gravity data concerning distribution of the basement complex, then underthrusting of the continent took place along the Jolon-Rinconada fault zone during the first episode of displacement on the zone. This interpretation is corroborated by the proximity along the zone of plutonic rocks of the Salinian block and older or contemporaneous sedimentary rocks that lack evidence of nearby intrusion; these plutonic and sedimentary rocks were originally farther apart and were brought together by underthrusting. According to Page (1970), underthrusting along the west side of the Salinian block probably ceased by the end of Oligocene time if not before. This time for the end of the first episode is supported by the similarity of Miocene and later rocks and by the dissimilarity of pre-Miocene rocks across the fault zone.

Evidence from Miocene and younger rocks indicates a second episode of displacement on the Jolon-Rinconada fault zone. Contemporaneous but lithologically dissimilar upper Tertiary stratigraphic sequences in the Tierra Redonda Mountain, Bradley, and Adelaida quadrangles are in contact across the Jolon fault for about 11 miles; this fact suggests a strike-slip displacement greater than 11 miles (Durham, 1965b). The Pancho Rico Formation extends farther south on the east side of the fault than it does on the west side, and the Santa Margarita Formation extends farther north on the west side of the fault than it does on the east side; both relations show right-lateral offset. The lack of a source area for huge boulders of granitic rock in the Tierra Redonda Formation in the Tierr. 


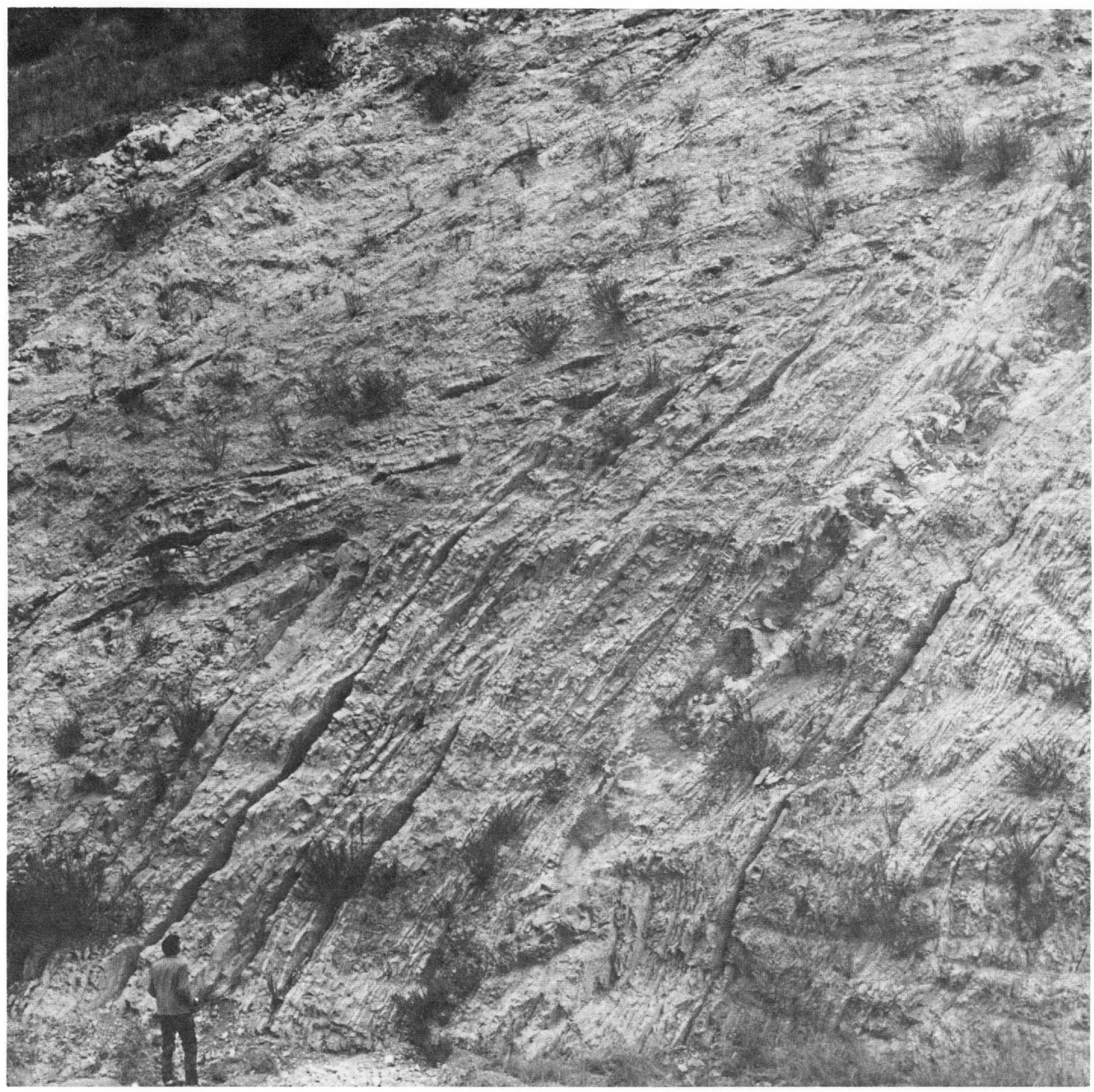

FiguRe 40.-Deformed beds in the Sandholdt Member of the Monterey Formation above the Bee Rock fault zone just north of the Nacimiento River. Nearby sandstone beds in the Tierra Redonda Formation beneath the fault zone are only moderately tilted.

Redonda Mountain quadrangle also suggests strikeslip fault displacement. The boulders are southwest of the Jolon fault, and their large size (fig. 21) indicates a nearby source, but the nearest granitic rocks that are not covered by strata as old as the Tierra Redonda are on the Lockwood high (pl. 3), about 7 miles away. However, restoration of about 15 miles of right-lateral

displacement along the Jolon fault would bring granitic rocks that crop out near Paso Robles close to the boulder beds; these granitic rocks are not covered by beds as old as the Tierra Redonda and could have been exposed when the boulder beds formed. Because parts of the Paso Robles Formation near the Jolon-Rinconada fault zone are deformed to the same degree as the 
older Miocene and Pliocene units, the second episode of displacement of the zone occurred during or after deposition of the Paso Robles-that is, in late Pliocene or Pleistocene time.

The second episode of displacement on the JolonRinconada fault zone involved right-lateral movement similar to that on the nearby San Andreas fault zone. The second episode may have been geologically brief, for late Tertiary or early Quaternary structural features other than the Jolon-Rinconada fault zone are more compatible with northeast-southwest crustal shortening than with the northwest-southeast rightlateral shear characteristic of the San Andreas. The right-lateral stress associated with movement on the San Andreas apparently was partly relieved along the Jolon-Rinconada zone, which, if it were the locus of pre-Miocene underthrusting of the southwest border of the Salinian block, could have been a weak place especially susceptible to rupture. The bulge where the margin of the Salinian block appears offset from the Jolon fault to the Sam Jones and Sur-Nacimiento fault zones (fig. 37) may represent an irregularity in the old continental margin that blocked lateral offset along the Jolon-Rinconada zone during the second episode of displacement and caused movement along the Jolon fault to die out northwestward.

\section{AREA NORTHEAST OF JOLON-RINCONADA FAULT ZONE}

\section{CONFIGURATION OF THE BASEMENT COMPLEX}

The surface of the basement complex northeast of the Jolon-Rinconada fault zone (pl. 3) has high areas - the Gabilan, Junipero Serra, Lockwood, and La Panza highs - separated by a series of interconnected troughlike depressions, all apparently formed by warping and faulting of the basement rocks. The distribution and structure of sedimentary rocks on the basement complex suggest that the configuration of the basement-complex surface is the result of deformation of an area that was broader than the present area. The distribution of Tertiary beds around and over the Gabilan, Lockwood, and La Panza highs (fig. 9) indicates that these features were topographic highs during most of Tertiary time, unless lower Tertiary sediments were stripped from large areas during middle or late Tertiary time. The distribution of Tertiary beds around the Junipero Serra high, by contrast, shows that this feature is a more recent structural and topographic high at the site of a depression where sediments accumulated throughout most of Tertiary time. The relief on the basement-complex surface in the mapped area (pl. 3) is about 17,000 feet, measured from the top of Pinyon Peak (5,264 $\mathrm{ft}$ above sea level) in the Junipero Serra Peak quadrangle to the deepest part of the depression near Hames Valley (about 12,000 ft below sea level).

The Gabilan high (pl. 2, structure sections D-D' to $\mathrm{H}-\mathrm{H}^{\prime}$ ) is a broad irregular feature on the basementcomplex surface and appears to be the southern subsurface extension of the Gabilan Range. The basementcomplex surface is uneven on the high and has considerable local relief that lacks expression in the overlying beds. A concealed domelike feature near the margin of the high in the Paraiso Springs quadrangle, for example, is more than 1,000 feet above the surrounding basement-complex surface (pl. 2, structure section $\mathrm{C}-\mathrm{C}^{\prime}$ ), but the structure of overlying exposed beds fail to reflect it; the small Monroe Swell oil field is located over the flank of the feature. Data from the Murdock Oil Marian 1 well (map no. 153) in the San Lucas quadrangle provide another example of relief on the basement-complex surface. The well penetrated sedimentary rocks for more than 5,000 feet, although nearby wells reached the basement complex at considerably shallower depths. The anomalously thick sequence of beds in the well fills a depression in the concealed basement-complex surface; the depression is interpreted to be a canyonlike feature on the structure map (pl. 3 ), although it could be a downdropped fault block of pre-Pliocene sedimentary rocks.

Strata of late Miocene and Pliocene age fill a deep trough along the northeast side of the Gabilan high near Peachtree Valley (pl. 2, structure sections D-D' to $\mathrm{H}-\mathrm{H}^{\prime}, \mathrm{Q}-\mathrm{Q}^{\prime}$ ). The trough and the high have similar depositional histories; they appear to be elevated and depressed parts of a major structural block that includes the Gabilan Range. The Sierra de Salinas, which is uplifted along a fault west of the Salinas River, seems to be part of the same major structural block.

The southwest margin of the Gabilan high either ends or is offset abruptly to the northeast near Indian Valley. Burch (in Burch and Durham, 1970, p. B12B13) interpreted an apparent offset of gravity features along Indian Valley as evidence of a fault, but surface evidence of faulting near Indian Valley is lacking; if a fault does affect the basement complex there, it must antedate the Miocene and Pliocene sedimentary-rock cover.

The Lockwood high (pl. 2, structure sections F-F', $\mathrm{G}-\mathrm{G}^{\prime}$ ) is a buried ridgelike feature on the basementcomplex surface in the Espinosa Canyon and Williams Hill quadrangles. Though it lacks surface expression, it has more than 4,000 feet of relief. The straightness and steepness of the northeast side of the high suggest uplift of the basement complex there along a fault; the high abuts the Jolon-Rinconada fault zone to the south.

The La Panza high (pl. 2, structure sections $\mathrm{N}-\mathrm{N}^{\prime}$, $\mathrm{O}-\mathrm{O}^{\prime}, \mathrm{P}-\mathrm{P}^{\prime}$ ) extends northward in the subsurface from 


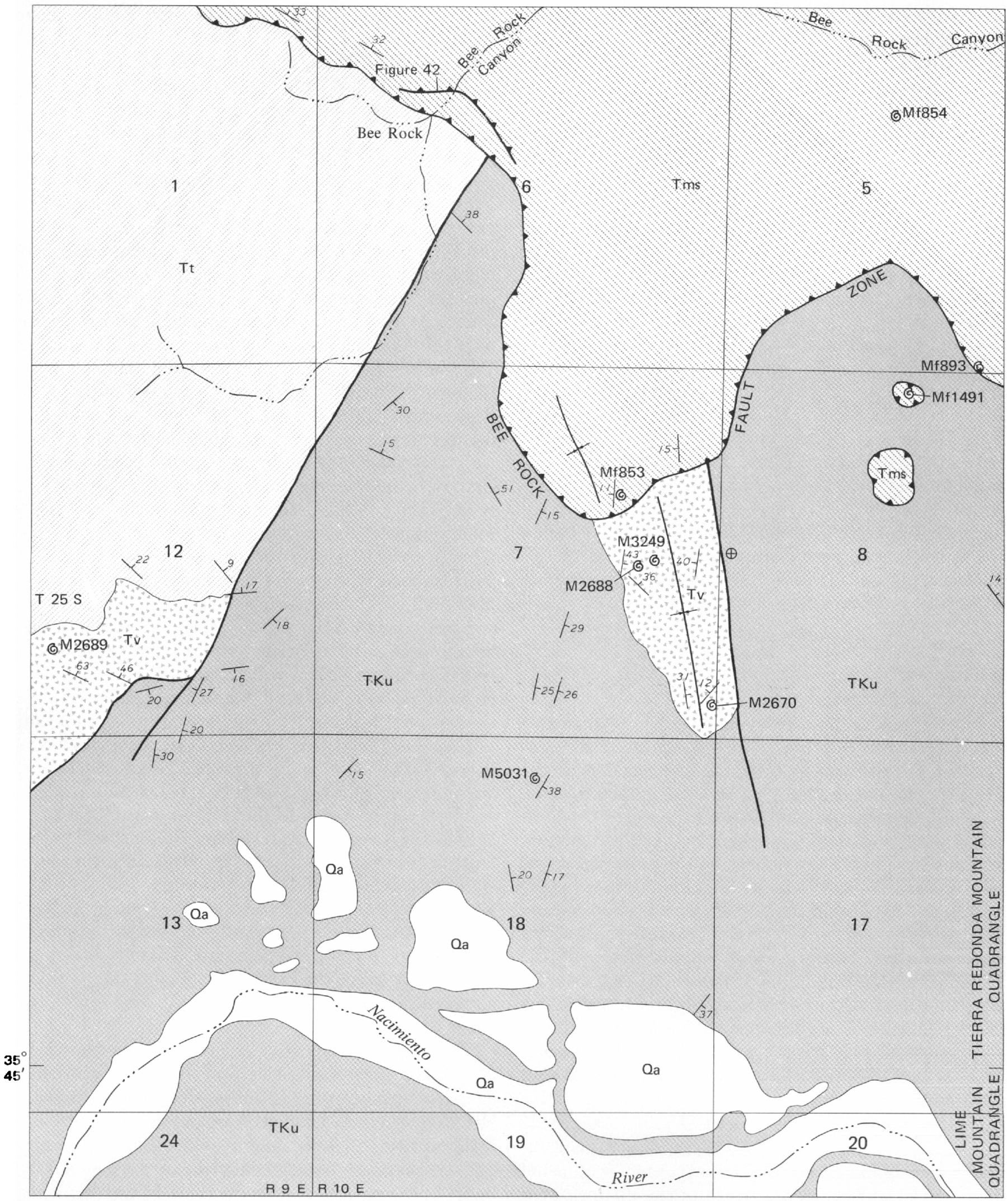

FIGURg 41.-Geologic sketch map of the Bee Rock area, Tierra Redonda Mountain and Lime Mountain quadrangles. 


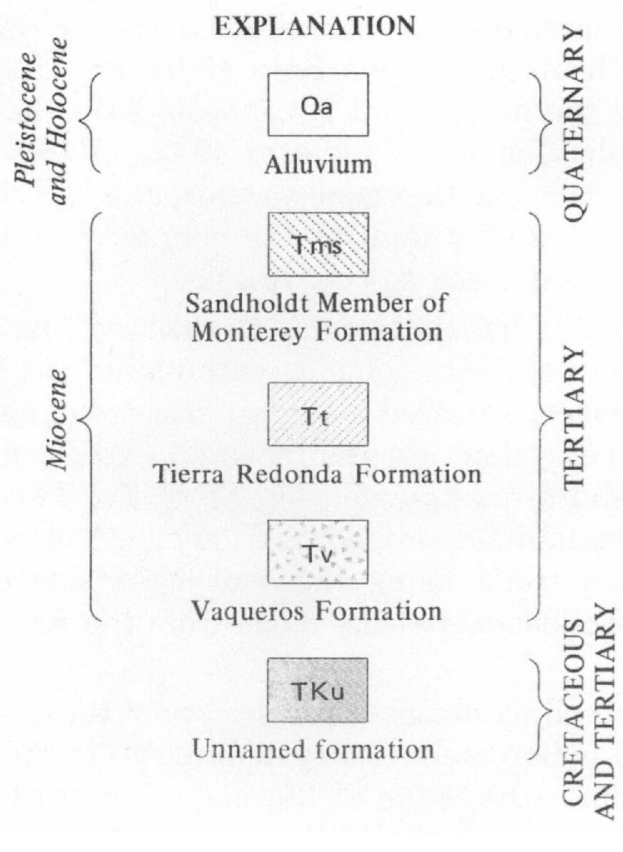

Contact

Gradational or approximately located

Fault

Approximately located

Thrust fault

Approximately located. Sawteeth on upper plate

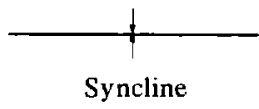

Showing troughline; approximately located

$\stackrel{22}{\text { Inclined }} \stackrel{\oplus}{\oplus}$

Strike and dip of beds

G M3249

Fossil locality
The Junipero Serra high (pl. 2, structure sections $B-B^{\prime}, C-C^{\prime} D-D^{\prime} R-R^{\prime}$ ) is a fault-bounded feature in the northwestern part of the mapped area. Basement complex crops out in the core of the high, and sedimentary rocks that range in age from Eocene to Pliocene outline and reflect the shape of the feature. Structural relief of the high is at least 13,000 feet.

A troughlike depression in the basement-complex surface between the Gabilan and Junipero Serra highs (pl. 2, structure sections B-B' to D-D') follows the Arroyo Seco and trends southeastward beneath the hills on the west side of the Salinas River into the Espinosa Canyon quadrangle. Faults affect the north and northeast sides of the depression only moderately, but faults around the Junipero Serra high determine the shape of the south and southwest sides of the feature. Data from the Shell Oil Shell-Texas-Beedy 1 well (pl. 4, No. 59) indicate that the deepest part of the depression is more than 8,000 feet below sea level.

Another deep depression in the basement-complex surface lies between the Gabilan and Lockwood highs in and near the Hames Valley quadrangle (pl. 2, structure sections $\mathrm{F}-\mathrm{F}^{\prime}$ to $\mathrm{H}-\mathrm{H}^{\prime}$ ). Well data show that near Hames Valley the northeast side of the depression slopes southwestward about 3,500 feet per mile, and the deepest part of the feature is $10,000-12,000$ feet below sea level. Well information about the configuration of the depression is scant, but gravity data suggest

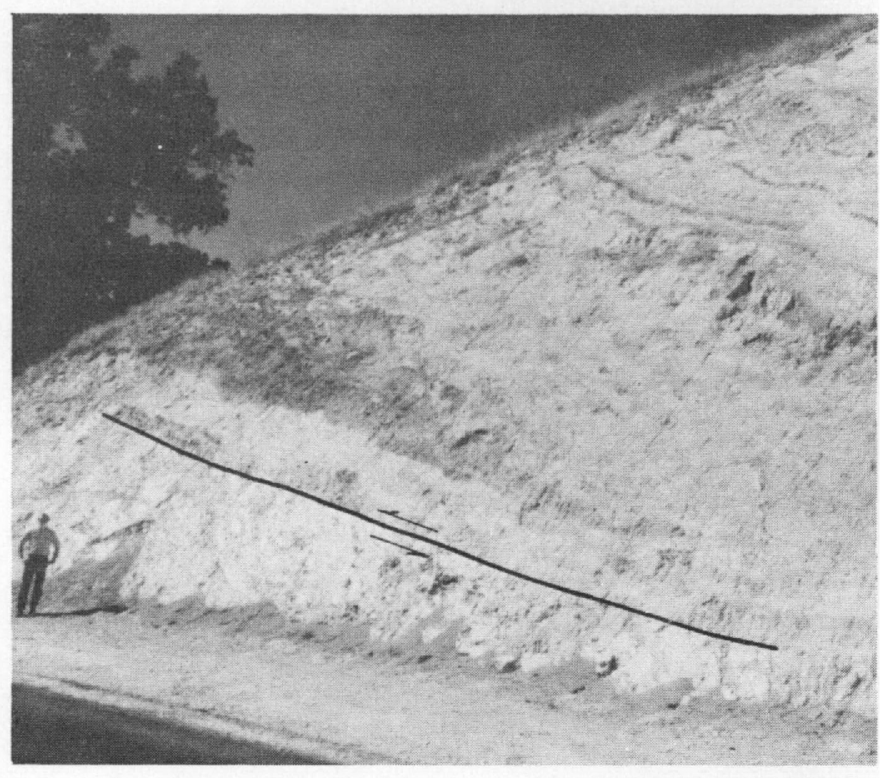

Figure 42-Thrust fault in the Sandholdt Member of the Monterey Formation north of Bee Rock (fig. 41), Tierra Redonda Mountain quadrangle. The fault is an element of the Bee Rock fault zone. Rocks above and below the fault are crushed and broken; beds below dip to the north (right), and those above are nearly parallel to the fault. 
the general size and shape of the feature (pl. 3, bouguer gravity map).

Well and gravity data outline a broad irregular depression on the basement-complex surface north of the La Panza high (pl. 3). The configuration of the feature near Vineyard Canyon is interpreted largely from gravity data (Burch and Durham, 1970, pl. 1) because of the lack of deep-well information.

\section{FAULTS}

Faults are uncommon over the Gabilan high but are common at most other places in the mapped area where rocks older than the Paso Robles Formation crop out (pl. 1). The apparent absence of faults in much of the Paso Robles terrane may be due partly to lack of good exposures and partly to concealment of deformed rocks by unconformably overlying Paso Robles beds. The sedimentary-rock cover over the Gabilan high, where the basement complex has been little deformed since burial, is too thin to deform independently of the underlying basement complex. By contrast, the thick sequence of beds in the hills between the Salinas and San Antonio River valleys has been severely deformed. The fault pattern in the mapped area has a conspicuous northwest trend except around the Junipero Serra high and along the Arroyo Seco where it trends more nearly west.

The Sierra de Salinas borders the west side of the Salinas Valley north of the Arroyo Seco for about 25 miles. The steep straight northeast face of the range has long been considered the physiographic expression of a fault, generally called the King City fault. Lawson $(1893$, p. 154) noted the remarkable linearity of the Salinas Valley, which he called "a valley of erosion (probably along a fault line)" (p. 155). He later (Lawson, chm., and others, 1908 , p. 19) described a fault "at the base of the Santa Lucia Range [Sierra de Salinas] on the border of Salinas Valley" that "is probably the chief factor in determining the course of the Salinas-Valley and the steep easterly front of the Santa Lucia Range [Sierra de Salinas]." Nickell (1931, p. 314) considered a surface of low relief on top of the Sierra de Salinas as the uplifted western continuation of a similar surface on the Gabilan Range. Direct evidence of the King City fault is lacking because alluvial fans at the base of the Sierra de Salinas conceal older rocks and are themselves unfaulted, but physiographic evidence of the fault seems compelling. The dip and displacement of the King City fault are unknown, but the boldness of the northeast front of the Sierra de Salinas suggests that the fault has a large vertical component of movement. Evidence of the King City fault south of the Sierra de Salinas is lacking. The idea that the fault follows the edge of the hills west of the Salinas River south of the Arroyo Seco (Kilkenny, 1948, p. $2265)$ and the notion that it connects with the Reliz fault in Reliz Canyon (Taliaferro, 1943a, p. 159) seem unlikely because neither concept preserves the character of the King City fault as the boundary of an elevated basement block to the west.

Rocks of the basement complex exposed just south of the main basement-complex outcrops of the Sierra de Salinas were elevated along an east-trending fault system. The system apparently is an extension from the Jamesburg quadrangle (fig. 1) of the Tularcitos and Paloma faults described by Fiedler (1944, p. 236238), which trend along the southwest side of the Sierra de Salinas across the range from the King City fault.

The exposed basement-complex core of the Junipero Serra high is bordered by a system of faults that generally outlines the shape of the high. Beds of Eocene age unconformably overlie the basement complex at a few places, but elsewhere at the surface Eocene and younger beds are in fault contact with the basement complex. Faults along the north side of the Junipero Serra high trend westward and appear to connect to the west with the Willow Creek fault described by Dickinson $(1959 ; 1965$, p. 40). Faults in the Reliz Canyon and Thompson Canyon quadrangles trend southeast around the high, and faults in the Cosio Knob quadrangle trend south and southwest to outline the faulted southeast nose of the feature.

The thick sequence of upper Miocene strata in the hills between the Salinas and San Antonio River valleys overlies a troughlike depression on the concealed basement-complex surface between the Gabilan and Lockwood highs. Beds near the margins of the hills on both side generally are more severely deformed than are beds near the center of the hills. A thrust fault, the Los Lobos fault, dips southwest beneath the hills along the Salinas River in the Hames Valley quadrangle (pl. 2 , structure sections $\mathrm{G}-\mathrm{G}^{\prime}, \mathrm{H}-\mathrm{H}^{\prime}, \mathrm{I}^{-\mathrm{I}^{\prime}}$ ); beds in the upper plate are severely deformed, in contrast to the nearly flat-lying beds of the Paso Robles Formation east of the fault. A complementary thrust fault, the San Antonio fault, dips northeast on the other side of the hills in the Hames Valley and Tierra Redonda Mountain quadrangles (pl. 2, structure sections $\mathrm{H}-\mathrm{H}^{\prime}$, I-I'). A thrust or reverse fault that dips northeast beneath the hills in and near the Cosio Knob quadrangle may be a northwest extension of the San Antonio fault (pl. 2, structure sections E-E', F-F'). The Espinosa fault zone trends northwest through the hills from the San Antonio River into the Espinosa Canyon quadrangle; the trace of the fault is marked by crushed and 
contorted beds of the Monterey Formation and lies over the buried northeast edge of the Lockwood high.

The Huerhuero fault is a conspicuous feature along the East Branch of Huerhuero Creek in the Wilson Corner quadrangle. Marine Miocene beds crop out on the east side of the fault, but the Paso Robles Formation lies on the basement complex on the west side. However, Miocene rocks occur west of the fault in the subsurface farther north; the apparent offset of Miocene rocks across the Huerhuero fault suggests rightlateral strike-slip displacement of 4-5 miles. Scanty well data also suggest right-lateral strike-slip displacement of the concealed basement complex (pl. 3 ).

\section{GEOLOGIC HISTORY}

A framework for interpreting the geologic history of the southern Salinas Valley area is provided by readily observable stratigraphic, structural, and physiographic features. Obviously, more than one interpretation is possible from the same set of data, but the history outlined here seems consistent with available information and accounts for features and relations throughout the area. The interpretation presented is based on the assumption that the original extent of stratigraphic units can be inferred from present distribution-that is, strata were not deposited and then stripped away from large areas, except over modern topographic features. Any interpretation must consider also that the area lies in a tectonically active region where spatial relations are subject to change. Because interpretation of the development of structural features is dependent largely on the distribution of rock-stratigraphic units and because tectonics is involved in the evolution of modern topography, the sedimentary, structural, and physiographic histories of the area are treated separately. A tabulation of the integrated geologic history follows the separate discussions.

\section{SEDIMENTATION}

The sedimentary history of the southern Salinas Valley area from Late Cretaceous to early Pliocene time is largely a history of marine deposition. The rocks are mainly arkosic, which indicates a source in the granitic basement complex of the Salinian block, rather than in the Franciscan Formation to the east or west. The first Franciscan debris appears in the sedimentary record in Pliocene time, when apparently the Franciscan cores of nearby ranges were uncovered. The distribution of sedimentary rock units generally suggests that the open sea was west of the area and land lay to the east or northeast. This implies that unless islands lay to the west most of the sediment came from along or near the east side of the area, or from farther east across the San Andreas fault zone before displacement along the San Andreas removed possible granitic source areas far to the southeast.

Sand and gravel accumulated in the southwestern part of the mapped area more or less continuously during Late Cretaceous and Paleocene time, and muddy sediments accumulated there locally at the same times. Clast composition indicates that the sediments were derived from erosion or unroofing of a granitic-basement terrane, rather than a Franciscan Formation terrane; the clast composition therefore implies derivation from the Salinian block. The area northeast of the Jolon-Rinconada fault zone is a likely source for the sediments, but displacement along the fault zone has probably distorted areal relations of the rocks and their source. Fossils suggest an inner neritic marine environment for at least part of the coarser sediments, and outer neritic or deeper marine conditions for the mud.

Sand and mud accumulated in the mapped area in Eocene time only in the northwestern part, where fossils indicate a bathyal depth for the mud; probably the sand, like the mud, collected in a marine environment. The lack of Eocene strata in the mapped area outside the northwestern part suggests that most of the area was land in Eocene time; Eocene beds preserved in downfaulted blocks in the Santa Lucia Range west of the mapped area indicate that the open Eocene sea lay to the west. Eventually, mainly in Oligocene time, poorly sorted sand and gravel covered the marine Eocene sediments; their texture suggests a nonmarine, perhaps fluviatile environment. The sand and gravel and the underlying marine Eocene sediments had about the same extent in the mapped area; this fact implies that both collected in a single depression on the Salinian block and that the depression persisted as a low place after withdrawal of the sea.

In early Miocene time, the sea encroached upon the mapped area to a greater extent than at any previous time for which a sedimentary record remains. A thick blanket of sand formed in what fossils indicate generally was a very shallow water and warm-water marine environment. The evidence from fossils of shallowwater conditions requires that sediment accumulation kept pace with subsidence in parts of the area. Fossils in mudstone deposited near the end of early Miocene time record an abrupt deepening of the sea to bathyal depths in at least part of the area. The distribution of lower Miocene rocks suggests that a marine embayment occupied the southeastern part of the mapped area, but the shape of the original area of lower Miocene marine deposition undoubtedly was distorted by later tectonic activity. 
In middle Miocene time, the sea covered nearly all the mapped area; only in the northeastern part does the lack of middle Miocene beds suggest land. Richly organic siliceous mud accumulated at most places, and sand collected where the sea encroached upon topographically high areas above and below sea level. Fossils indicate that the mud accumulated at abyssal to neritic depths; the average depth decreased during middle Miocene time, and fossils record a general and abrupt shallowing of the sea near the end of that time. Fossils indicate that the sand collected in a warm water and shallow water nearshore marine environment.

In late Miocene time, the sea covered most of the mapped area. Richly organic siliceous mud accumulated, mainly in the western part, and arkosic sand was common around topographic highs and in the southeastern part of the area. The upper Miocene sediments probably accumulated in shallower water than had most of the middle Miocene mud; fossils generally indicate that the upper Miocene sand accumulated in the upper part of the inner sublittoral zone and in a warm temperate to subtropical marine climate. Some upper Miocene sandstone in the southeastern part of the area lacks an obvious nearby source in the Salinian block; its source may have been to the east across the San Andreas fault, before displacement along the San Andreas moved possible granitic source areas far to the southeast. Cherty debris in some sandstone indicates that uplift had exposed rocks of the Monterey Formation to erosion in or near the area; this uplift may have signaled the beginning of the final withdrawal of the Tertiary sea from the region.

By early Pliocene time, the sea had withdrawn from the southern part of the mapped area and had finally extended across the Gabilan high in the northeastern part. Fine-grained sand was the dominant sediment that collected in the Pliocene sea, but coarser grained sand, gravel, and mud-especially diatomaceous mud -accumulated locally. Fossils indicate that most of the sand collected in a shallow water nearshore warm temperate or marginally subtropical marine climate and in normal marine salinity. The sand deposits were thickest, and the sand was finest grained in the northwestern part of the area, where, according to evidence from fossils, water was deepest.

Nonmarine sand, gravel, and mud covered the marine Pliocene sediments after the sea withdrew, and by late Pliocene time they covered most, if not all, of the mapped area. The texture of the sand and gravel suggests fluviatile deposits derived largely from the west and south, where uplift of the coastal mountains provided an abundance of coarse clasts-largely from the Monterey Formation. Finer grained sediments accum- ulated in lakes, including limy mud in brackish-water lakes. Gypsum formed in some lakes, and plant material collected in swampy places. The occurrence of marine fossils interbedded with conglomerate of the Paso Robles Formation in the southern part of the area suggests a temporary incursion of an arm of the Pliocene sea there, probably from the west or southwest, and perhaps after final withdrawal of the sea from the northern part of the area.

The concluding episode in the depositional history of the area involves mainly sand, gravel, and mud brought by rivers into the valleys in late Pleistocene and Holocene time. Mudflow, lacustrine, and dune deposits are locally conspicuous.

\section{DEVELOPMENT OF STRUCTURAL FEATURES}

Relief features on the basement-complex surface are of two types: Those formed during or before early Tertiary time, and those formed during or after latest Tertiary time, when most of the structural features in the sedimentary-rock cover also developed. The distribution of rock-stratigraphic units in contact with the basement complex shows progressive burial of an irregular basement-complex surface (fig. 9), provided that erosion did not strip away beds from large parts of the area during the Tertiary. Strata older than Miocene are absent from the Gabilan, Lockwood, and La Panza highs (figs. 12, 16), and the lower Miocene Vaqueros Formation occurs only in depressions around the highs (fig. 18); both circumstances indicate that the highs were topographic elevations before and during early Miocene time. The encroachment of successively younger units onto the highs implies gradual reduction of the topographic expression of the features during later Tertiary time. The succession of Tertiary strata near the Gabilan and La Panza highs lacks unconformities or other internal evidence of deformation during Tertiary time; this circumstance suggests that the highs formed prior to deposition of the sedimentary rocks around them. By contrast, well data show that Miocene Relizian and Luisian Stage beds are absent over part of the Lockwood high, although older and younger Miocene strata occur there. This lacuna in the Miocene record indicates a period of erosion or nondeposition on the Lockwood high, and may reflect renewed uplift of the high during Miocene time.

The distribution of rock-stratigraphic units in the northwestern part of the mapped area shows that the site of the Junipero Serra high was a topographic depression in which sediments accumulated from Eocene until latest Tertiary time. The lack of a hiatus in the Tertiary record there suggests that the high began to form after deposition of the Pliocene Pancho 
Rico Formation, and perhaps after deposition of part of the Pliocene and Pleistocene(?) Paso Robles Formation. The correspondence of the fault pattern around the high to the configuration of the high itself indicates that the pattern reflects uplift of the basement complex beneath a sedimentary-rock cover; it follows that the troughlike shape of the depression in the basement-complex surface between the Gabilan and Junipero Serra highs developed after deposition of the sedimentary rocks that fill it.

The distribution of Miocene rocks around the Hames Valley quadrangle (figs. $18,22,23$ ) indicates that a topographic depression existed there at the beginning of Miocene time. Stratigraphic relations on the northeast side of the depression show progressive burial of the sloping surface of the basement by successively younger beds; the nature of the southwest side of the feature is uncertain. The pattern of severe deformation and thrusting along the San Antonio and Salinas Rivers, where strata over the depression in the basementcomplex surface impinge upon the neighboring Lockwood and Gabilan highs, suggests crustal shortening between the highs and consequent compression of the sedimentary-rock cover. Downwarping of the basement-complex surface during crustal shortening may account for part of the great depth of the depression near Hames Valley; coincident compression of the sedimentary-rock cover may explain uplift of hills over the depression.

Faults northeast of the Jolon-Rinconada fault zone affect the Pliocene Pancho Rico Formation and older rocks to the same degree and also affect the Pliocene and Pleistocene(?) Paso Robles Formation. These relations demonstrate that most of the faulting was in late Pliocene or Pleistocene time. Conspicuous evidence of Holocene faulting, such as scarps on stream terraces or offsets of roads and fences, is lacking in the mapped area.

Right-lateral strike-slip displacement along large northwest-trending faults between the San Andreas and Jolon-Rinconada fault zones might be expected because the two zones have that kind of displacement, but except possibly for the Huerhuero fault, convincing evidence of such displacement is wanting. Instead, the shape or trend of most structural features in the granitic basement complex and the overlying sedimentary-rock cover suggest vertical displacement and crustal shortening. Burford $(1966$, p. $109 ; 1968)$ found by strain analysis of an elongate triangulation network across the southern part of the mapped area that northeast-southwest crustal shortening dominated the pattern of movement there during the 20 -year period from 1932-51, and that right-lateral simple shear is the predominant strain only near the San Andreas fault zone. If the northeast-southwest crustal shortening prevailed at times in the past, it would account for the northwest trend of many structural features in the mapped area. It would explain crustal shortening across the depression in the basement-complex surface near Hames Valley and the attendant deformation of the sedimentary-rock cover. It might also explain the puzzling westward bend of structural features around the north side of the Junipero Serra high as the effect of relative northeastward movement of the core of the Junipero Serra high toward the Gabilan high; this speculation is corroborated by evidence that the basement complex of the Junipero Serra high is shortened in a northeast-southwest direction (Compton, 1966b, p. 1378). Similarly, the Espinosa fault zone could be an expression in the sedimentary-rock cover of relative northwestward displacement of the Lockwood high, the northwest margin of which lies beneath the trace of the fault zone.

\section{STRUCTURAL INTERPRETATION OF TOPOGRAPHY}

Some topographic features in the mapped area are closely related to the structure of underlying rocks. The closeness of the course of the Salinas River and the trend of the Rinconada and other faults at the south end of the area suggests that the position of the river there is structurally controlled. The dissected old land surface in the upland tract northwest of Paso Robles (B, fig. 7) terminates abruptly at the Jolon fault; this fact implies displacement of the surface by the fault. If the surface antedates most of the several miles of right-lateral strike-slip displacement attributed to the Jolon-Rinconada fault zone, then the old land surface in the upland tracts near the south edge of the mapped area (C, fig. 7) could be an offset part of the surface northwest of Paso Robles.

The closeness of the course of the San Antonio River and the trend of the Jolon fault suggests structural control of this river too. Bifurcation of the San Antonio River valley near Lockwood might have been caused by uplift of hills along the Jolon fault and consequent shifting of the river to a more southerly course; this change would leave the valley around Lockwood to be filled with debris from the north, while few streams were able to maintain their courses across the hills to reach the San Antonio River.

Severe deformation, including thrusting (pl. 2 , structure sections $\mathrm{H}-\mathrm{H}^{\prime}, \mathrm{I}-\mathrm{I}^{\prime}$ ), of rocks along both margins of the hills between the San Antonio and Salinas Rivers, indicates that the outline and relief of the hills is of tectonic origin. The hills delineate a broad arch that contrasts with the tilted old land surface across 
the Salinas River to the east; the drainage divide along the hills has a median position, and streams generally have straight courses from the divide to the adjacent valleys (fig. 3). These drainage features suggest symmetrical arching of a long area and concurrent establishment of consequent streams. Uplift of the hills may have influenced the course of the San Antonio River by forming a barrier to northeastward streamflow; the lack of streams that breach the hills implies uplift too rapid for maintenance of any preexisting stream through the hills. The close correspondence of the drainage divide along the hills to the trace of the Espinosa fault zone suggests some relation between the zone and uplift of the hills.

Comparison of topographic features with the configuration of the basement-complex surface (pl. 3 ) reveals some obscure relations between topography and structure. The position of the Salinas River near and parallel to the concealed southwest margin of the Gabilan high suggests that the initial course of the river there was in a long topographic depression between the westward-tilted Gabilan high and the uplifted arch of the hills to the west. The Arroyo Seco, the only stream that breaches the mountains in the northwestern part of the mapped area, lies near the axis of a troughlike depression in the basement-complex surface, the only such structural indentation in the mountains; this position implies that initially the Arroyo Seco was able to maintain its course across the mountains as they formed by following a structurally controlled topographic depression. The Estrella River also follows a trough in the concealed basement-complex surface, but the significance, if any, of the position is uncertain.

The nearly opposite flow directions of the Salinas River and two of its tributaries, the Nacimiento and San Antonio Rivers, can be explained if the courses of the Nacimiento and San Antonio are relics of the earlier drainage system that deposited the Paso Robles Formation. If the Paso Robles in the Estrella River valley area was deposited by streams flowing southeastward from the Santa Lucia Range and northward from the La Panza Range into a trunk stream that flowed eastward along the general course of the modern Estrella River (Galehouse, 1967, p. 973), and if near the end of deposition of the Paso Robles the drainage system was blocked to the east (Galehouse, 1967, p. 973), then after deposition of the Paso Robles the early drainage of the Nacimiento River and its tributaries may have been into a closed basin. The lowland area of moderate relief that generally is $200-300$ feet, and in places as high as 500 feet above the modern Salinas River and its larger tributaries south of the Bradley quadrangle, may represent the floor of the closed basin.
Following this interpretation, the drainage system of the closed basin was eventually captured by the lower Salinas River, either by headward erosion of the Salinas through hills in the Wunpost quadrangle or by filling and overlow to the north of a lake in the closed basin. In either circumstance, downcutting by the Salinas and its newfound tributaries would have been rapid, if not catastrophic. If the capture was effected by overflow of a lake standing unusually high, then in a short time a large amount of water might have poured through and scoured out the lower Salinas River valley. Terraces along the Salinas north of San Ardo that generally are 100-200 feet above the modern river may represent the ancient floor of the Salinas River valley before the river captured the southern drainage system; low northwest-trending linear topographic features on the terraces may record a cataclysmic flood. The linear features have been considered old sand-dune deposits (Weidman, 1958, p. 158-169), but northwest-trending hills north of San Lucas that have been mapped as sand dunes (Jennings and Strand, 1958) contain some granular clasts that seem too coarse for wind transport - even by the prevailing gales of the Salinas Valley. Instead of dunes, these and other linear features on the terraces may represent sandbars left by a great flood and later superficially modified by the wind.

The old land surface represented by accordant ridges in the upland tract in the northeastern part of the mapped area dips southwest (A, fig. 7), but conglomerate in the Paso Robles Formation that caps ridges there most likely came from a western source because it lacks pebbles of rocks, such as Franciscan chert, that are common to the east. Thus, the old land surface probably sloped northeast originally and was tilted southwestward later. The larger streams that dissect the old land surface have straight courses (fig. 3 ) that suggest consequent streams established on a newly tilted area. The asymmetry of the valleys of streams between San Lorenzo Creek and Indian Valley can be explained if the direction of tilting became more southerly near the end of the tilting episode. Such a slight change in the direction of tilting would cause streams already established in a southwesterly course to seek the south side of their valleys, which would in turn cause asymmetry of the valley cross sections as downcutting continued. Streams farther south that initially flowed more nearly to the south would simply have their gradients steepened by increased tilt to the south; they would not develop valleys with asymmetric cross sections. The headward termination near the San Andreas fault zone of many of the valleys suggests that displacement along the zone beheaded the streams that formed the valleys. The modified radial drainage pattern around the 
structural high in the southern part of the Adelaida quadrangle (fig. 3 ) and the coincidence of the hub of the pattern with the topographically highest part of the dissected old land surface in the upland tract northwest of Paso Robles (B, fig. 7) imply that the old land surface was dissected by streams that formed after uplift of the structural high. Less pronounced radial drainage patterns associated with structural highs in the Reliz Canyon and Santa Margarita quadrangles may also reflect consequent drainage from upwarped areas. The fact that the divide between the San Antonio River and Arroyo Seco drainage areas (fig. 3) follows closely the crest of the Junipero Serra high suggests that streams there formed consequent to uplift of the high.

\section{SUMMARY OF GEOLOGIC HISTORY}

Table 1 lists events in the geologic history of the southern Salinas Valley area and summarizes data and conclusions discussed in greater detail in the sections on "Stratigraphy" and "Structure." The parts of the mapped area northeast and southwest of the JolonRinconada fault zone have unlike early histories and are treated separately in the pre-Miocene chronicle; the Miocene and later histories of the two parts are similar.

\section{ECONOMIC GEOLOGY}

Rocks and sediments of the southern Salinas Valley area have yielded a variety of commercially valuable commodities including oil and gas, bituminous rock, diatomite, gold, gypsum, mineral water, sand and gravel, stone, and tuff. The economic geology map (pl. 4) shows oil fields, mines, quarries, and areas that contain conspicuous outcrops of bituminous rock; it also lists and shows the location of exploratory wells, producing oil wells, and selected core holes drilled outside the San Ardo oil field before July 1969.

\section{PETROLEUM}

Surface indications of oil attracted pioneer oil prospectors to the mapped area near the end of the 19th century, but the first commercial production began 50 years later. Exploration was especially vigorous near outcrops of bituminous rock west of San Ardo and along the San Antonio River, but the early wells were commercial failures; the quarrying of bituminous rock for use as street paving was a more rewarding early venture. Finally, discovery in 1947 of the San Ardo oil field prompted considerable wildcat drilling that eventually led to discovery of several smaller fields.

Evidence of petroleum is common in the Monterey Formation. Tar-stained rock composed almost entirely of foraminifer tests crops out near the top of the Sandholdt Member of the Monterey in Reliz Canyon (fig. 24 ), and calcareous mudstone and dolomite of the Sandholdt elsewhere have a fetid petroliferous odor when freshly broken. Stalder (1924, p. 58) mentioned "several tar seepages *** near the base of the shales" along Vaqueros Creek, and "dry petroleum residues" in fractured chert west of King City near the mouth of Pine Canyon. Laizure (1925b, p. 528) stated that a sample of "oil shale" from the Sandholdt west of Adelaida yielded $16.5^{\circ}$ Baumé gravity oil at the rate of $81 / 3$ gallons to the ton in laboratory analysis. Tar occurs in fractured cherty rocks of the Hames Member of the Monterey near the mouth of Piney Creek and in the heart of an anticline just north of the Nacimiento River in the Bradley quadrangle, where it forms a dry black coating on joint surfaces and fills cracks in the rock. Tar also occurs in the Hames Member just below bituminous sandstone beds exposed along the San Antonio River; a tarry residue stains sandstone associated with porcelaneous rocks of the Hames Member in the Stockdale Mountain quadrangle near the Eureka Oil well 2 (pl. 4, No. 466).

\section{OIL FIELDS}

Oil and gas produced in the southern Salinas Valley area are mainly from the San Ardo oil field (tables 2 and 3). Most fields in the area are similar in that they yield oil from sandstone beds associated with finegrained rocks of the Monterey Formation. Experience suggests that the most likely places for future oil discoveries are near where the Monterey Formation and the sandy Tierra Redonda and Santa Margarita Formations intertongue (generally in the stippled areas shown in figs. 22 and 23 ).

\section{SAN ARDO OIL FIELD}

The San Ardo oil field lies across the Salinas River in the Hames Valley and Wunpost quadrangles (pl. 4). Discovery of the field came in 1947 after nearby wells showed signs of oil. Production is from sandstone units of late Miocene age (here assigned to the San Margarita Formation) near the margin of the Gabilan high. The basement complex beneath the east part of the field forms an irregular shelflike surface 1,800-2,100 feet below sea level that slopes steeply southwestward under the west part of the field. The sandy productive zones are stratigraphically equivalent to fine-grained beds of the Hames Member of the Monterey Formation; the accumulation of sandy rather than finegrained sediments in the field area presumably was influenced by a nearby source of sand from the Gabilan high. The limits of the field are mainly controlled by tilted oil-water interfaces and by permeability barriers (Colvin, 1963). In 1969 the San Ardo oil field had an 
TABLE 1.-Summary of geologic history

\begin{tabular}{|c|c|c|c|}
\hline \multicolumn{2}{|c|}{$\begin{array}{l}\text { Period } \\
\text { and } \\
\text { epoch }\end{array}$} & Event & Geologic record or evidence \\
\hline 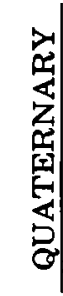 & | & 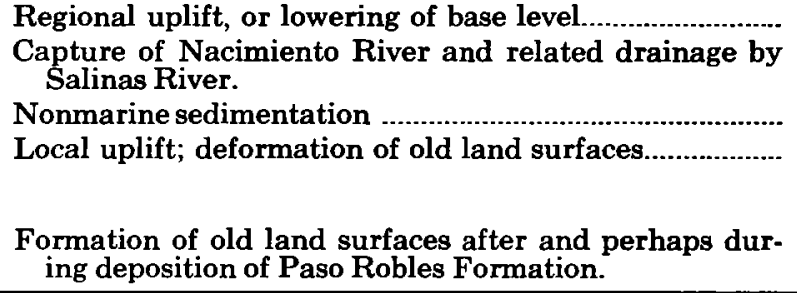 & $\begin{array}{l}\text { Terraces along major streams. } \\
\text { Near reversal in direction of flow of Nacimiento River } \\
\text { water after it enters the Salinas River. } \\
\text { Alluvium. } \\
\text { Antecedent and consequent streams; fans at base of hills; } \\
\text { termination of old land surface (B, fig. } 7 \text { ) against Jolon } \\
\text { fault. } \\
\text { Accordant ridges, some capped with Paso Robles } \\
\text { Formation. }\end{array}$ \\
\hline 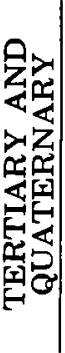 & 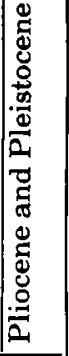 & $\begin{array}{l}\text { Tectonic disruption of drainage system that functioned } \\
\text { during deposition of the Paso Robles Formation; } \\
\text { creation of lakes. } \\
\text { Faulting and folding ...................................................... } \\
\text { Right-lateral strike-slip displacement along Jolon- } \\
\text { Rinconada fault zone, and northeast to southwest } \\
\text { crustal shortening. } \\
\text { Nonmarine sedimentation }\end{array}$ & $\begin{array}{l}\text { Unconformity between Paso Robles Formation and old } \\
\text { alluvium; lacustrine sediments in Paso Robles. } \\
\text { Deformation of Paso Robles Formation to same degree as } \\
\text { older beds at most places; local unconformity at base of } \\
\text { Paso Robles. } \\
\text { Offset pinchout lines of both Pancho Rico and Santa Mar- } \\
\text { garita Formations, and general northwest strike of fold } \\
\text { axes and thrust faults. } \\
\text { Paso Robles Formation. }\end{array}$ \\
\hline \multirow{5}{*}{ 至 } & 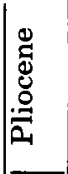 & 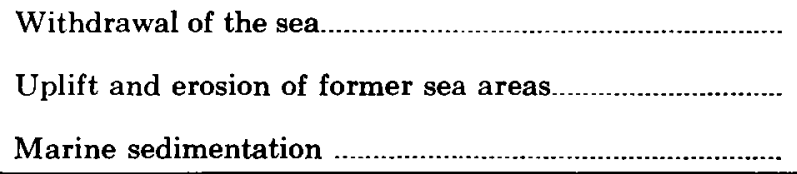 & $\begin{array}{l}\text { Intertonguing of marine Pancho Rico and nonmarine Paso } \\
\text { Robles Formations; southward pinchout of Pancho Rico. } \\
\text { Debris from Monterey Formation in Pancho Rico and } \\
\text { Paso Robles Formations. } \\
\text { Marine fossils in Pancho Rico Formation. }\end{array}$ \\
\hline & 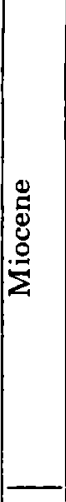 & 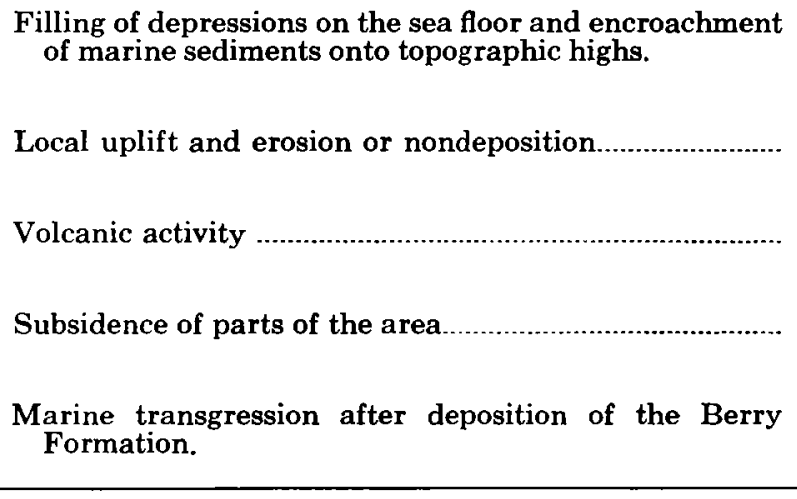 & $\begin{array}{l}\text { General shallow-water aspect of marine fossils in Santa } \\
\text { Margarita Formation and upper part of Monterey For- } \\
\text { mation; greater extent of upper Miocene, as compared } \\
\text { with middle Miocene marine units. } \\
\text { Absence of Relizian and Luisian Stage beds over Lock- } \\
\text { wood high; chert grains from Monterey Formation in } \\
\text { some sandstone beds of the Santa Margarita Formation. } \\
\text { Tuff and bentonite beds in Monterey and Santa Marga- } \\
\text { rita Formations; olivine basalt and diabase associated } \\
\text { with Sandholdt Member of Monterey. } \\
\text { Deepwater aspect of foraminifers in Sandholdt Member } \\
\text { of Monterey Formation, as compared with shallow- } \\
\text { water fossils in underlying Vaqueros Formation. } \\
\text { Overlap of older rocks by the marine Vaqueros Formation; } \\
\text { generally wider distribution of successively younger } \\
\text { Miocene formations. }\end{array}$ \\
\hline & 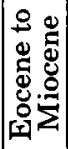 & $\begin{array}{l}\text { Temporary withdrawal of the sea from area northeast } \\
\text { of the Jolon-Rinconada fault zone. } \\
\text { Uplift, deformation, and erosion or nondeposition in } \\
\text { area southwest of the Jolon-Rinconada fault zone. }\end{array}$ & $\begin{array}{l}\text { Nonmarine aspect of Berry Formation, intertonguing of } \\
\text { Berry and marine fossil-bearing Vaqueros Formation. } \\
\text { Absence of strata between Paleocene and Miocene beds; } \\
\text { unconformity at base of Miocene beds. }\end{array}$ \\
\hline & 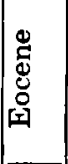 & $\begin{array}{l}\text { Marine sedimentation locally northeast of the Jolon- } \\
\text { Rinconada fault zone. } \\
\text { Formation by Eocene time of relief on pre-Tertiary } \\
\text { basement-complex surface by faulting, warping, or } \\
\text { uplift and erosion. }\end{array}$ & $\begin{array}{l}\text { Eocene foraminifers in Reliz Canyon Formation. } \\
\text { Localization of Reliz Canyon Formation. }\end{array}$ \\
\hline & 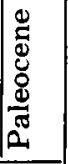 & $\begin{array}{l}\text { Erosion or nondeposition northeast of Jolon-Rinconada } \\
\text { fault zone. } \\
\text { Marine sedimentation southwest of Jolon-Rinconada } \\
\text { fault zone. }\end{array}$ & $\begin{array}{l}\text { Absence of recognized Paleocene strata. } \\
\text { Paleocene marine fossils is unnamed formation. }\end{array}$ \\
\hline \multirow{2}{*}{\multicolumn{2}{|c|}{ 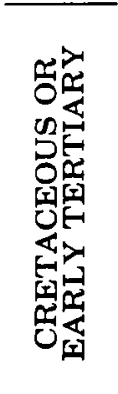 }} & Relative underthrusting of Salinian block from west. & $\begin{array}{l}\text { Proximity of pre-Tertiary plutonic rocks of Salinian block } \\
\text { and contemporaneous beds to the southwest that lack } \\
\text { evidence of nearby intrusion and that presumably do } \\
\text { not overlie Salinian-block basement complex. } \\
\text { Absence of rocks older than Tertiary on basement com- } \\
\text { plex northeast of Jolon-Rinconada fault zone. }\end{array}$ \\
\hline & & $\begin{array}{l}\text { Folding, deep-seated metamorphism, and emplacement } \\
\text { of plutonic rock in the Salinian block. } \\
\text { Marine sedimentation southwest of the Jolon- } \\
\text { Rinconada fault zone, probably on older marine } \\
\text { strata (Franciscan Formation) that lie on oceanic } \\
\text { crust. }\end{array}$ & $\begin{array}{l}\text { Deformed metamorphic rocks intruded by granitic rocks } \\
\text { that have Cretaceous radiometric ages. } \\
\text { Cretaceous marine fossils in unnamed formation; lack of } \\
\text { geologic or geophysical evidence of Salinian-block base- } \\
\text { ment complex beneath Cretaceous beds. }\end{array}$ \\
\hline
\end{tabular}


TABLE 2.-Oil production (barrels) from the southern Salinas Valley area, 1947-69

[Source of data: California Oil Fielda v. 33-55 (1947-69)]

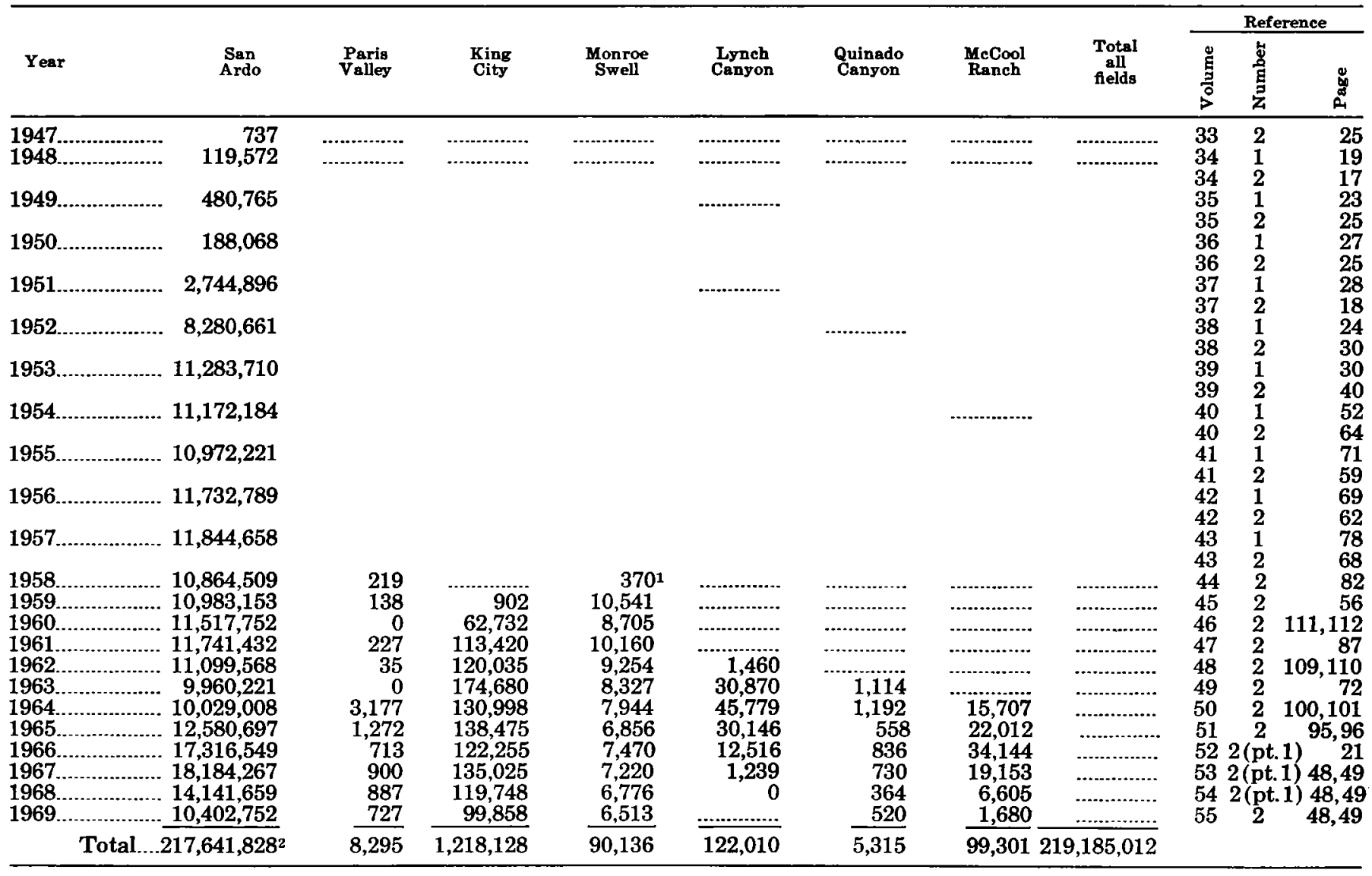

1Not listed in California Oil Fields but included in cumulative total, v. 45, no. 2 , p. 56 .
2California Oil Fields, v. 55 , no. 2, p. 49 , gives cumulative total of $217,655,963$, based on adjustment in v. 37 , no. 2, p. 18, and revision in v. 46, no. 2 , p. 112 .

average of 868 producing wells on 4,370 proved acres (California Oil Fields, v. 55, no. 2, p. 49). The following papers give additional information on the field: Baldwin (1949, 1950, 1953), Baldwin and others (1951), Barger and Zulberti (1949), Bradford and Lawrence (1956), Campbell (1948), Colvin (1963), Durham (1966); Fackler (1953), Hart (1966), Kilkenny and others (1952), Miller (1953), Rintoul (1961, 1964, 1965, 1966a, b, 1967), Simm (1964), and Thorup (1948).

\section{PARIS VALLEY OIL FIELD}

The Paris Valley oil field is in the San Ardo quadrangle just west of the Salinas River (pl. 4). The discovery well, the W. Frank Jones Marport-Ansberry 1 (pl. 4, No. 241), was only 798 feet deep and was completed in 1958; initial production was 12 barrels per day of $12.4^{\circ}$ gravity oil with 4 percent cut. Production is from upper Miocene sandstone beds (here assigned to the Santa Margarita Formation) that are associated with a ridgelike feature on the concealed basementcomplex surface at the margin of the Gabilan high. Smith $(1963$, p. 80) showed an elongate-dome con- figuration for the highest productive zone in the field. Only one well produced in 1969 , on 30 proved acres (California Oil Fields, v. 55, no. 2, p. 49). Hart (1966), Rintoul (1964), and Smith (1963) gave additional information on the field.

\section{KING CITY OIL FIELD}

The King City oil field is at the edge of the hills west of the Salinas River in the Thompson Canyon and San Lucas quadrangles (pl. 4). The discovery well, the R. R. Thorup Thomas Doud Estate 2 (pl. 4, No. 174), was completed in 1959; initial production was 76 barrels per day of $16.5^{\circ}$ gravity oil with 30 percent cut (Church, 1963a, p. 60). The second well, the R. R. Thorup Thomas Doud Estate 3 (pl. 4, No. 175), was completed pumping 414 barrels per day of $16.6^{\circ}$ gravity clean oil (Church, 1963a, p. 60). Production is from middle Miocene sandstone beds (here assigned to the Tierra Redonda Formation) that are stratigraphically equivalent to fine-grained rocks of the Sandholdt Member of the Monterey Formation farther west; the accumulation of sandy rather than fine-grained beds in 


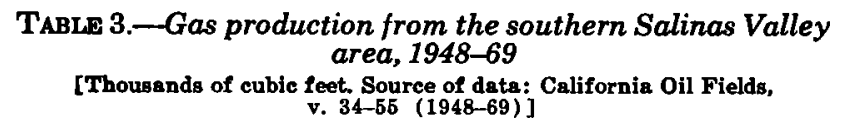
area, 1948-69

[Thousands of cubic feet. Source of data: California Oil Fields, v. 34-55 $(1948-69)]$

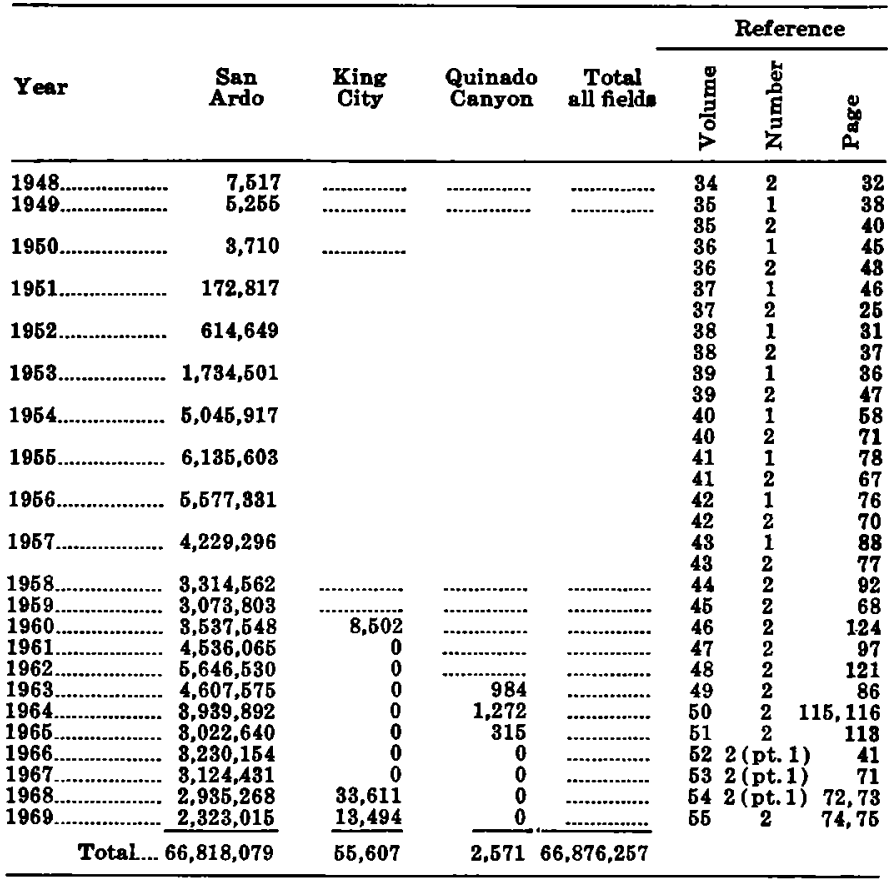

the field area presumably was influenced by a nearby source of sand from the Gabilan high. Church (1963a) showed the oil trapped in faulted anticlines. In 1969, the field had an average of 19 producing wells on 210 proved acres (California Oil Fields, v. 55, No. 2, p. 48). Church (1963a, b), Hart (1966), and Thorup (1961) gave additional information on the field.

\section{MONROE SWELL OIL FIELD}

The Monroe Swell oil field is west of the Salinas River in the Paraiso Springs and Greenfield quadrangles (pl. 4). The discovery well, the Texas Beedy (NCT-2) 1 (pl. 4, No. 17), was completed in 1949 pumping 30 barrels per day of $16.9^{\circ}$ gravity oil, but operations were suspended after a short time, and the well eventually was abandoned (Gribi, 1963b). A second pool was found in the field by the Bandini Petroleum Doud 54X-19 well (pl. 4, No. 21); this well was completed in 1959, pumping 75 barrels per day of $19^{\circ}$ gravity oil with $10-15$ percent cut. Production is from upper Miocene sandstone beds (here assigned to the Santa Margarita Formation) that are stratigraphically equivalent to fine-grained rocks in the Hames Member of the Monterey Formation farther west. The sandstone is associated with a prominence on the concealed basement-complex surface near the margin of the Gabilan high (pl. 3). The oil is trapped in an anticline and in stratigraphic traps on the flank of the anticline (Gribi, 1936b). The field had one producing well in 1969, on 20 proved acres (California Oil Fields, v. 55 , no. 2 , p. 49 ). Gribi (1963b) and Hart (1966) gave additional information on the field.

\section{LYNCH CANYON OIL FIELD}

The Lynch Canyon oil field is east of the Salinas River in the Pancho Rico Valley and Wunpost quadrangles, about 3 miles north of the San Ardo oil field (pl. 4). The discovery well, the Moriqui Exploration Lanigan 172 (pl. 4, No. 423), was completed in 1962, pumping 44 barrels per day of $11^{\circ}$ gravity clean oil. Production was from an upper Miocene sandstone unit (here assigned to the Santa Margarita Formation) associated with a prominence on the basementcomplex surface of the Gabilan high. Entrapment of oil involved a thinning of the productive zone to the northeast, where the zone laps onto the basement complex, and a gradation of sandstone to siltstone or silty shale to the southwest (Wilkinson, 1964, p. 83). The field was abandoned in 1968. Gribi (1963a), Hart (1966), Rintoul (1964), and Wilkinson (1964) gave additional information on the field.

\section{McCOOL RANCH OIL FIELD}

The McCool Ranch oil field is in the hills east of the Salinas River in the Pancho Rico Valley and Wunpost quadrangles, about $1 \frac{1}{2}$ miles north of the San Ardo oil field (pl. 4). The discovery well, the C. A. Luckey Sinclair 5 (pl. 4, No. 306), was completed in 1964 and reportedly had initial production of 62 barrels per day of $11.7^{\circ}$ gravity oil with 84.5 percent cut. Production is from an upper Miocene sandstone unit (here assigned to the Santa Margarita Formation) that forms a stratigraphic trap where it laps onto the gently westward-sloping basement-complex surface of the Gabilan high (Wilkinson, 1965, p. 78). The field had one producing well in 1969, on 90 proved acres (California Oil Fields, v. 55, no. 2, p. 49). Wilkinson (1965) gave additional information on the field.

\section{BITUMINOUS ROCK}

Bituminous rock is conspicious at several localities in the mapped area and was mined for paving material. It crops out locally west of the Salinas River from Monroe Canyon to the Nacimiento River, and east of the Salinas River near San Lorenzo Creek and Indian Valley (pl. 4). Most of the exposed bituminous rock is simply stained by a dark asphaltic residue, although locally asphalt impregnates and even seeps from the rock.

Bituminous rock that crops out west of King City, southwest of San Lucas, and west of San Ardo is in the lower part of the Pancho Rico Formation; the 
Pancho Rico at these places is massive fine-grained sandstone that conformably overlies the Hames Member of the Monterey Formation. The bituminous rock west of King City crops out near the mouth of Thompson Canyon and northwest of the canyon for about $2 \frac{1}{2}$ miles; it is best seen on the south side of Thompson Canyon-outcrops farther northwest are discontinuous. The bituminous rock west of San Ardo crops out intermittently for about 5 miles from the south end of Paris Valley to the San Ardo oil field. It is well exposed near the mouth of Garrissere Canyon at the north line of sec. 13, T. 22 S., R. 9 E.; according to Ball Associates, Ltd. (1965, p. 67), two samples of the rock from a 22 -foot thick bed in sec. 13 contained 3.58 and 8.90 percent oil. Eldridge $(1901$, p. 410$)$ reported that bituminous rock near San Ardo was "prospected in a slight degree."

Bituminous rock that crops out northeast of King City near San Lorenzo Creek is also in the lower part of the Pancho Rico Formation; the Pancho Rico there lies on the basement complex, and the Monterey Formation is absent. The bituminous rock is coarsegrained conglomeratic sandstone that probably is near the base of the Pancho Rico, but the base is concealed, and nearby outcrops of basement complex are faulted against the Pancho Rico. The rock is impregnated with asphalt and oozes sticky tar at some places. Bituminous rock was produced there from the Mylar Quarry (pl. 4), before 1900 and used to surface streets in King City (Preston, 1893, p. 259). According to Ball Associates, Ltd. (1965, p. 66), three samples of the rock contained 8.57 to 14.41 percent oil.

Bituminous rock in the lower part of the Paso Robles Formation ${ }^{5}$ crops out on both sides of the San Antonio River in the Bradley quadrangles. The Paso Robles overlies the Hames Member of the Monterey Formation there with a slight angular unconformity. Asphalt-impregnated sandstone at the base of the Paso Robles is about 10 feet thick (fig. 43), and a second zone of asphalt-impregnated conglomerate about 25 feet above the base is 5 feet thick. The beds dip $40^{\circ}-$ $60^{\circ}$ and form bold outcrops. Bituminous rock was quarried at this locality in the late 19th century for road paving. According to Ball Associates, Ltd. (1965, p. 68), the rock contains 10.49 percent oil.

Bituminous rock that crops out on the north side of the Nacimiento River in the Bradley quadrangle (fig. 44) is in lenticular sandstone bodies 10-15 feet thick at or near the top of the Hames Member of the Monterey Formation. The deposit lacks any sign of development.

${ }^{5}$ N. L. Taliaferro, in unpublished field notes dated May 21, 1940, noted fossil mollusk shells in the bituminous rock at this locality; these fossils might indicate that the beds should be assigned to the Pancho Rico Formation.

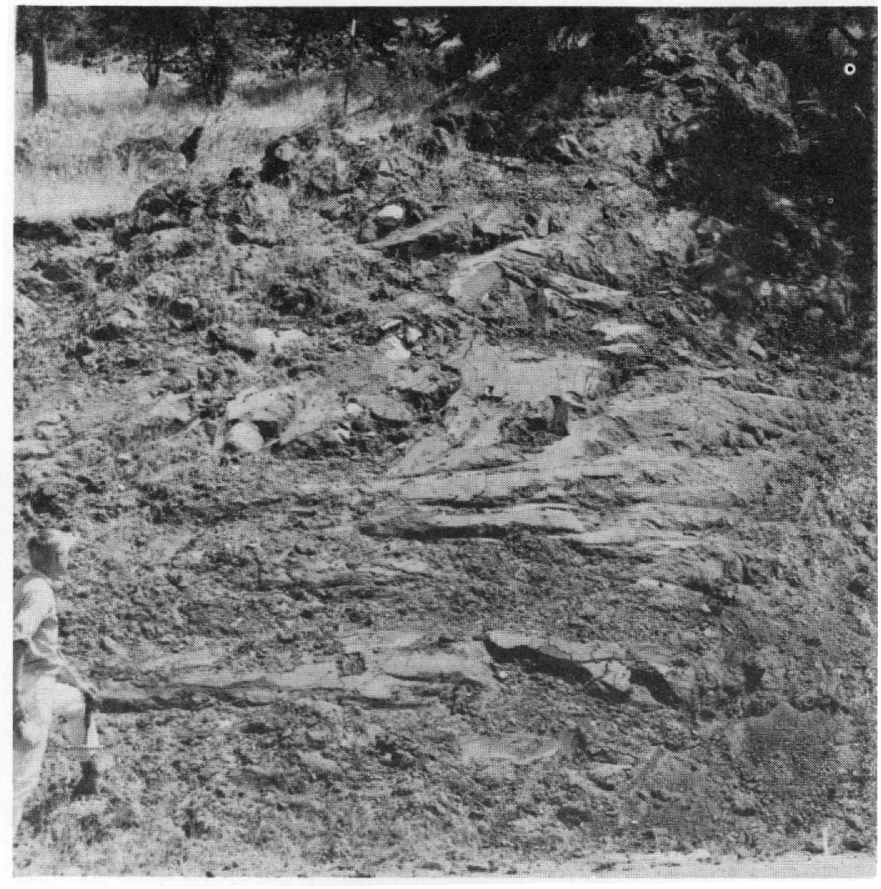

Frgure 43.-Bituminous sandstone at the base of the Paso Robles Formation south of the San Antonio River, Bradley quadrangle. The Paso Robles overlies porcelaneous and cherty rocks of the Monterey Formation (bottom right) with a slight angular unconformity.

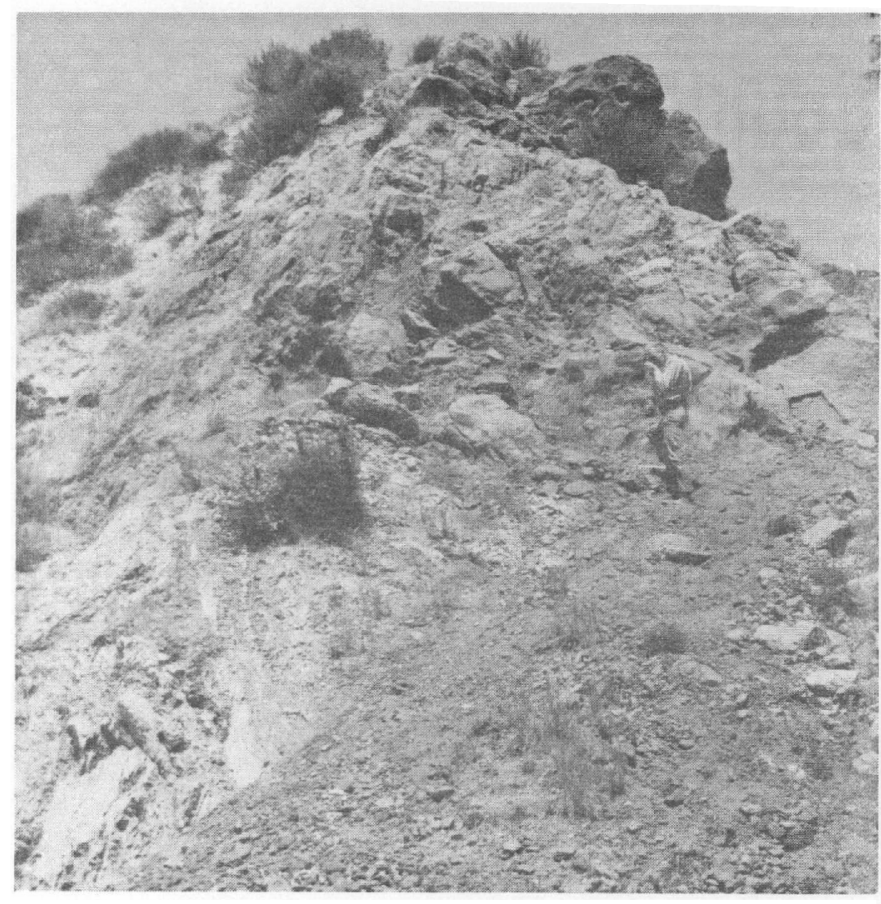

Figure 44.-Lenticular bituminous sandstone body near the top of the Monterey Formation north of the Nacimiento River in the Bradley quadrangle. 
The following papers mention or describe bituminous rock in the southern Salinas Valley area: Adams and Beatty $(1962$, p. 3), Ball (1951, p. 17-18), Ball Associates, Ltd. (1965, p. 66-68), Bell, (1960, table 3), Bramlette and Daviess (1944), Crawford (1894, p. $29 ; 1896$, p. 36$)$, Eldridge (1901, p. 407-412; 1903, p. 303), English (1918, p. 240-245), Fairbanks (1900), Goodyear $(1888$, p. 85-87), Hail (1957, p. 61-62, 66), Hamlin (1904, p. 17-19), Hart (1966, p. 29-31, 120), Jennings (1957, p. 61-62), Laizure (1925a, p. 28), Pack and English (1915, p. 146), Preston (1893, p. 259), Taliaferro (1943b, p. 460), Vander Leck (1922, p. 229), and Waring and Bradley (1917, p. 596).

\section{OCCURRENCE}

Surface indications of oil in the mapped area generally are poor evidence that oil is trapped nearby in the subsurface. Fairbanks (1896) long ago pointed out the folly of drilling for oil near seeps in the area without first considering the attendant geologic conditions. The known occurrences of petroleum in the Salinas Valley suggest that the thick sequence of organic marine sediments that accumulated there during Miocene and Pliocene time provided an ample source for oil and gas. Surface and subsurface data show that these sediments were mainly fine grained, but where they impinged upon topographic highs the fine-grained sediments generally gave way to sand or sandy rubble; these sandy sediments became the reservoir rocks in the larger oil fields of the area. The general lack of sandy beds intercalated with finer grained strata away from the highs indicates that conditions were unfavorable for sandy turbidite or channel sediments similar to those that formed prolific reservoir rocks in many California oil fields. Rather, oil must be sought for and has been found in the sandy blanket that mantles the irregular concealed basement-complex surface as a consequence of the progressive filling of depressions on the surface and eventual burial of it by sandy sediments. Known oil occurrences show that this sandy blanket and tongues of sandstone that project from it are potential petroleum reservoirs; much oil exploration in the mapped area has been based on this potential. Comparison of the distribution of wells on the economic geology map (pl. 4) with the configuration of the basement-complex surface on the structure map (pl. 3) suggests that the margins of the basement-complex highs are inadequately tested.

\section{DIATOMITE}

Diatomite produced commercially in the mapped area came from the Buttle Member of the Monterey Formation. Diatomaceous rocks occur also in the
Pancho Rico Formation, but they generally are less pure or less extensive than in the Buttle. Plate 4 shows the location of the principal diatomite mines and quarries in the area.

Diatomite production from the Buttle Member of the Monterey Formation around Hames Valley began as early as 1904 (Aubury, 1906, p. 292) but ceased by 1942 (Hart, 1966, p. 38). Waring and Bradley (1917, p. 598-599) described a diatomite mine north of Hames Valley (sec. 20, T. 23 S., R. 10 E.) that was in operation as early as 1905; the material from the mine was used as building blocks for interior fireproof walls. Laizure (1925a, p. 32-33) described a diatomite mining operation begun in 1922 south of Hames Valley (sec. 15, T. 24 S., R. 10 E.); the diatomite which was taken both from open cuts and from tunnels, was trucked to San Miguel where it was ground and sacked. Laizure also mentioned (p. 35-36) a diatomite deposit near Copperhead Creek in the Bryson quadrangle (sec. 18, T. 24 S., R. 9 E.) that was undeveloped. Aubury (1906, p. 293) noted a small exposure of "infusorial earth" in the Bradley quadrangle (sec. 11, T. 25 S., R. $10 \mathrm{E}$.), which is near some abandoned diatomite workings (sec. 2, T. 25 S., R. 10 E.).

The following papers give additional information on diatomite occurrence and mining: Aubury (1906, p. 292-293), Eakle (1914, p. 69), Hart (1966, p. 36-41), Laizure (1925a, p. 32-33, 35-36), Oakeshott (1957, p. 191), and Waring and Bradley (1917, p. 598-599).

\section{GOLD}

Placer gold was recovered from alluvium in the San Antonio River, Nacimiento River, and San Marcos Creek. Trask (1854, p. 58) reported:

Near San Antonio there were several persons at work during the past summer [1853], in the placers in this vicinity. This was no new discovery, for the existence of gold at this locality has been known since 1850 . Those at work at this place were mostly Mexicans, and while traveling on the Salinas I frequently met companies of five or six, with their camp material and tools, wending their way to this section.

Irelan (1888, p. 405) stated:

At one time over one hundred Chinese were engaged in gold washing in the vicinity of Jolon, it being supposed that the land in the neighborhood was Government territory. It proved, however, to belong to the Milpitas Grant, and the owners compelled the Chinamen to discontinue their work. Gold washing was afterward carried on further west $* * *$. The gold was principally coarse gold nuggets, some of the value of $\$ 5$ being occasionally found.

Irelan added (p. 405) that in 1877 and 1878 the store owners at Jolon "took in $\$ 2,500$ in gold dust from the Chinamen," and noted (p. 530), "Gold has been and is still washed from sands in the bed of the San Marcos Creek, about four miles northwest of Paso Robles, during the wet months of the year, yielding, it is said, as 
high as from $\$ 3$ to $\$ 4$ per man per day." Waring and Bradley $(1917$, p. 606) mentioned that attempts in 1914 to recover placer gold north of Jolon were unprofitable, although prospecting with a pan showed good indications of gold. Gold is no longer mined in the southern Salinas Valley area. (For additional information on former placer-gold operations, see Angel, 1890a, 1890b, p. 578; Antisell, 1856, p. 48; Davis, 1912; Franke, 1935, p. 420-421; Haley, 1923, p. 153; Hart, 1966, p. 45, 126; Hill, 1923, p. 325 ; Irelan, 1888 p. 405, 530; Laizure, 1925a, p. 41-42; Preston, 1893, p. 260; Trask, 1854, p. 58; and Waring and Bradley, 1917, p. 606).

\section{GYPSUM}

Gypsum produced commercially in the mapped area came from the Paso Robles Formation. The gypsum is massive and fine grained; it occurs near the south end of the Gabilan Range (pl. 4) in lenticular bodies as thick as 6 feet (fig. 45). The Paso Robles is flat lying there, and the gypsum, which is interbedded with friable siltstone, is near the surface. According to Ver Planck (1952, p. 40), the gypsum lenses are as large as 300 yards in diameter. Mining of the deposits began as early as 1896 (Crawford, 1896, p. 504); in 1945 the gypsum was marketed for agricultural use and guaranteed to contain 85 percent $\mathrm{CaSO}_{4} \cdot 2 \mathrm{H}_{2} \mathrm{O}$ (Averill, 1947 , p. 51). The operation was abandoned in 1948 (Ver Planck, 1952, p. 40.). The following papers describe or mention the deposit: Aubury (1906, p. 287), Averill (1947, p. 51), Bradley and Logan (1917, p.

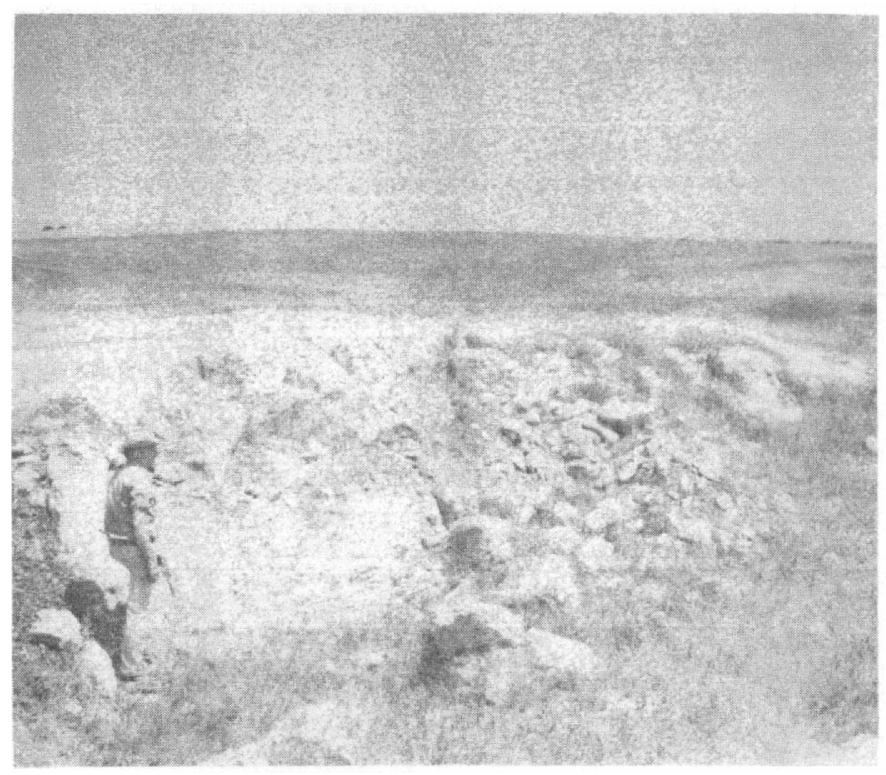

Figure 45.-Massive gypsum interbedded in the Paso Robles Formation at the south end of the Gabilan Range, Pinalito Peak quadrangle. The rock is nearly flat lying and has little overburden.
639), California Division of Mines (1956, p. 2), Crawford $(1896$, p. 504), Fairbanks (1904b, p. 120-121), Hess (1920, p. 80), and Ver Planck (1952, p. 40-41; 1957, p. 234).

\section{LIME AND LIMESTONE}

Lime was produced in the southern Salinas Valley area on a small scale during the late 19th century, mainly from deposits of fossil shells. Irelan (1888, p. 532) noted that fossil clams and oysters on the Santa Margarita land grant "when burnt, yielded a fair article of lime." Angel (1890b, p. 584) reported a "large bed of limestone, which is burned for lime quite extensively, producing an excellent article" at Oak Flat, which is about 4 miles northwest of Paso Robles. Preston $(1893$, p. 260$)$ noted the operation of a limekiln a few miles south of Jolon "working on a large shell deposit." Crawford (1894, p. 394) mentioned a "great mass" of Tertiary limestone " 3 miles N.W. of Adelaide P.O." where "in past years much lime of an excellent quality has been produced." He also noted (p. 394) similar limestone in a bed 100 feet thick about 10 miles northwest of Paso Robles.

Coarsely crystalline limestone in the basementcomplex just south of the Arroyo Seco is undeveloped. It is well exposed in and east of Horse Canyon in the Junipero Serra Peak and Reliz Canyon quadrangles.

The following papers give information on lime and limestone in the mapped area: Angel (1890b, p. 584), Crawford (1894, p. 394), Irelan (1888, p. 532), Laizure (1925b, p. 522), Logan (1917, p. 689), and Preston $(1893$, p. 260$)$.

\section{MINERAL WATER}

Hot and cold mineral-water springs and wells were the basis for development of popular spas at several places in the southern Salinas Valley area late in the 19th century. The largest developments were at Paso Robles and Paraiso Springs; springs at several other places were improved for private or for limited public use. The vogue for resorts utilizing mineral water eventually waned, and little evidence remains of the once flourishing enterprises. The following papers give data on springs and spas in the mapped area. Berkstresser (1968, p. A-8, ff), Crawford (1894, p. 340, 344), Franke (1935, p. 428-432), Goodyear (1888, p. 99), Hanks (1886, p. 67, 71-72), Hart (1966, p. 74, 134), Laizure (1925a, p. 45-47; 1925b, p. 524-527), Logan (1917, p. 690-697), Peale (1886, p. 204, ff), Waring and Bradley (1917, p. 607-609), and Waring (1915, p. 60-62, 72-77, 276-277).

\section{PHOSPhATE}

Phosphate in the Monterey and Pancho Rico For- 
mations has been prospected for but not produced commercially. Beds of pellet phosphate 2-6 inches thick are intercalated with porcelaneous rocks in the lower part of the Hames Member of the Monterey in a narrow belt from Vaqueros Creek in the Reliz Canyon quadrangle southeastward across Pine Canyon in the Thompson Canyon quadrangle. Similar pellet phosphate beds occur at the same stratigraphic position in the Bear Canyon quadrangle and near Indian Creek in the Wilson Corner quadrangle. Pellet phosphate beds stratigraphically higher in the Hames Member crop out north of the Arroyo Seco in the Sycamore Flat quadrangle, near the edge of the hills in the Espinosa Canyon quadrangle, and just west of Tule Canyon in the Williams Hill quadrangle. The pellet phosphate beds near Indian Creek were prospected extensively about 1962 .

Calcareous mudstone in the lower part of the Sandholdt Member of the Monterey Formation includes phosphatic laminae and lenses at some places, most notably along the Arroyo Seco in the Junipero Serra Peak quadrangle, near Copperhead Creek in the Bryson quadrangle, and at several localities in the York Mountain quadrangle. The Sandholdt also contains pellet phosphate along Jack Creek in the York Mountain quadrangle.

The Pancho Rico Formation east of the Salinas River contains small fossils, mollusks, pebbles, fish teeth, bones, and other debris that has a dark phosphatic coating or stain and is generally concentrated in particular beds. Bramlette and Daviess (1944) noted phosphate of this type southeast of San Lucas and phosphatic beds there were prospected in 1961-62 (Hart, 1966, p. 81).

The following papers mention or describe phosphate in the mapped area: Bramlette (1946, pl. 2), Bramlette and Daviess (1944), Dickert (1966, p. 295-298), Galliher (1931, p. 266), Gower (1966, p. 330), Gower and Madsen (1964), Hart (1966, p. 81, 134), Reed (1927), and Smith (1968).

\section{SAND AND GRAVEL}

Sand and gravel are produced in the mapped area mainly for short-term or intermittent local needs; sediment in stream beds and on terraces, and friable rock from the Paso Robles, Santa Margarita, and Tierra Redonda Formations have been used. Plate 4 shows the locations of some sand and gravel operations.

Sand and gravel that contain appreciable amounts of siliceous debris from the Monterey Formation are generally unsuitable for use in concrete. A local example of this unsuitability was given by Stanton (1948, p. 1058-1060), who described buckling and cracking of concrete made with fine aggregate from the Bradley quadrangle. Tests showed that excessive expansion of the concrete was caused when opalinerock clasts in the aggregate were acted upon by the caustic-reaction products of high-alkali-cement hydration to form sodium- or potassium-silica gel. Another example was the use of alluvium from the Nacimiento River as aggregate for concrete at the San Antonio Dam in preference to San Antonio River alluvium, which has a high content of Monterey debris near the dam.

The following papers contain data on sand and gravel deposits in the mapped area: California Division of Mines (1955, p. 5), Franke (1935, p. 457-458), Goldman (1962, p. 58; 1964, p. 22, 27, 40), Hart (1966, p. 100-106, 135-138), Laizure (1925a, p. 53), Logan (1917, p. 725-726), and Stanton (1948, p. 1058-1060).

\section{STONE}

Rock from the Monterey Formation is used for riprap and for ornamental building stone. Platy rock of the Sandholdt Member of the Monterey is quarried at two places near Adelaida (pl. 4) and sold locally as ornamental building rock; similar material is available at many places in the Sandholdt, but of course, only rock that is not too broken by joints is suitable for building purposes. Dolomite from the Sandholdt was used for the riprap facing on the San Antonio Dam; the rock was collected from surface exposures in the hills south of the dam, and similar rock could be collected from most outcrop areas of the Sandholdt. Franke (1935, p. 460) and Goldman (1962, p. 60) gave information on use of stone in the mapped area.

\section{TUFF}

Miocene tuff was mined in the mapped area for use as an abrasive or polish. Opencuts and the remains of a loading ramp about a mile west of Indian Creek in the Wilson Corner quadrangle are evidence that tuff at the base of the Santa Margarita Formation was mined there, but details of the operation are unknown. Tuff from the same unit was mined 2 miles farther east outside the mapped area for use as a polishing powder and cleaner (Laizure, 1925b, p. 537-538; Franke, 1935, p. 560-561). The "infusorial earth" that Angel (1890b, p. 583-584) reported mined near Adelaida for use as an abrasive polish was probably tuff in the Sandholdt Member of the Monterey Formation.

\section{COLLECTION-LOCALITY DESCRIPTIONS}

The following list includes most localities where fossils were collected during fieldwork for this report 
and gives supplemental localities from published and unpublished sources. The localities are listed by rockstratigraphic unit in ascending order; the entries for each unit are listed by $71 / 2$-minute quadrangle, beginning with the northwesternmost quadrangle in the mapped area and proceeding from west to east in rows from north to south; quadrangles are identified in figure 2. Each entry includes, where possible: (a) locality number, including field number, (b) general and specific location, (c) kinds of fossils collected, (d) age and correlation of fauna, (e) collector(s) and year(s) collected, (f) published reference to the locality, or unpublished source of information, and (g) additional remarks. Figure 46 shows surveyed land boundaries and identifies land grants in the southern Salinas Valley area. Except where noted otherwise, W. O. Addicott made age determinations and correlations on megainvertebrate fossils, and Patsy B. Smith made age determinations and correlations on fossil foraminifers. Institution abbreviations: LSJU, Leland Stanford Junior University; UC, University of California, Berkeley; UCLA, University of California, Los Angeles; USGS, U.S. Geological Survey.

Unnamed formation of Cretaceous and Paleocene age

Bryson quadrangle

USGS loc. M4190 (field No. 594008). In creek bank, $100 \mathrm{ft} \mathrm{N}$., 1,450 ft W. of SE. cor. sec. 5, T. $25 \mathrm{~S}$., R. 9 E., Fossils: mollusks. Age: Late Cretaceous. Collectors: D. L. Durham and R. J. McLaughlin, 1969. Remarks: fauna listed in text.

USGS loc. Mf1534 (field No. 694009). In bank of Kavanaugh Creek, 2,300 ft S., 4,350 ft E. of NW. cor. sec. 9, T. 25 S., R. 9 E. Fossils: foraminifers. Age: Late Cretaceous (R. L. Pierce, written commun., 1970). Collectors: D. L. Durham and R. J. McLaughlin, 1969. Remarks: faunas listed in text.

Unnumbered locality. In creek on line between secs. 4 and 5, T. 25 S., R. 9 E., about $400 \mathrm{ft} \mathrm{N}$. of SW. cor. sec. 4. Fossils: mollusks. Collector: N. L. Taliaferro, 1933. Reference: N. L. Taliaferro, unpub. field notes dated June 7, 1933.

Tierra Redonda Mountain quadrangle

USGS Mesozoic loc. M5031 (field No. 662028). In streambank $W$. of road, $0.6 \mathrm{mi} N$. of lake behind Nacimiento Dam, $650 \mathrm{ft}$ S., 2,550 ft W. of NE. cor. sec. 18, T. 25 S., R. 10 E. Fossils: mollusks. Age: Late Cretaceous. Collectors: D. L. Durham, 1966; W. O. Addicott and D. L. Durham, 1967. Reference: Durham, 1968a. Remarks: Originally numbered USGS Cenozoic locality M2672 (Durham, 1968a); fauna listed in text; fossil locality in figure 4.

No. 1939-0. In ctr. SW1/4NW1/4 sec. 17, T. 25 S., R. 10 E. Fossils: mollusks. Collector: N. L. Taliaferro, 1939. Reference: N. L. Taliaferro, unpub. field notes dated May 30, 1939.

No. 1939-Z. At extreme NW. cor. sec. 18, T. 25 S., R. 10 E. Fossils: mollusks. Collector: N. L. Taliaferro, 1939. Reference: N. L. Taliaferro, unpub. field notes dated June 6, 1939.
Unnamed formation of Cretaceous and Paleocene age-Con. Lime Mountain quadrangle

USGS loc. M4189 (field No. 694007). On E. side of Dip Creek, 2,300 ft S., $1,000 \mathrm{ft} \mathrm{W.} \mathrm{of} \mathrm{NE.} \mathrm{cor.} \mathrm{sec.}$ 30, T. 25 S., R. 10 E. Fossils: mollusks. Age: Cretaceous or Paleocene, Collectors: D. L. Durham and R. J. McLaughlin, 1969; W. O. Addicott, Kôichirô Masuda, D. L. Durham, and T. W. Dibblee, Jr., 1970. Remarks: fauna listed in text.

UC loc. A-1423. In SE $1 / 4$ NE $1 / 4$ sec. 30, T. 25 S., R. 10 E. Fossils: mollusks. Reference: Merriam, 1941, p. 70.

LSJU loc. 2208. "On knoll behind old Irving ranch house," $500 \mathrm{ft} \mathrm{N}$., 2,500 ft W. of SE. cor. sec. 6, T. 26 S., R. 10 E. Fossils: mollusks. Reference: Schenck and Childs, 1942, p. 28.

No. 1. At bend in creek, $300 \mathrm{ft}$ N., $200 \mathrm{ft} \mathrm{W}$. of SE. cor. sec. 20, T. 25 S., R. 10 E. Fossils: mollusks (baculites). Collector: C. E. Van Gundy, 1931-32. Reference: Van Gundy, 1934, p. 57.

No. 5 . In bed of Nacimiento River, $900 \mathrm{ft} \mathrm{S.,} 800 \mathrm{ft} \mathrm{W}$. of NE. cor. sec. 19, T. 25 S., R. 10 E. Fossils: mollusks. Collector: C. E. Van Gundy, 1931-32. Reference: Van Gundy, 1934, p. 57.

No. 6. On E. bank of Dip Creek, 2,500 ft S., 1,600 ft E, of NW. cor. sec. 4, T. 26 S., R. 10 E. Fossils: mollusks (oysters and Inoceramus). Collector: C. E. Van Gundy, 1931-32. Reference: Van Gundy, 1934, p. 57.

Unnumbered locality. On N. side of Nacimiento River, $300 \mathrm{ft}$ S., $1,400 \mathrm{ft}$ W. of NE. cor. sec. 19, T. $25 \mathrm{~S}$., R. 10 E. Fossils: mollusks. Collector: N. L. Taliaferro, 1932. Reference: N. L. Taliaferro, unpub. field notes dated May 22, 1932.

Unnumbered locality. On N. side of Nacimiento River, about $200 \mathrm{ft} S$., $500 \mathrm{ft} \mathrm{W}$. of NE. cor. sec. 19, T. 25 S., R. 10 E. Fossils: foraminifers. Collector: N. L. Taliaferro, 1932. Reference: N. L. Taliaferro, unpub. field notes dated May 22, 1932.

No. 1939-W. On S. bank of Nacimiento River at $120^{\circ} 55^{\prime}$ line of longitude. Fossils: mollusks (ammonites). Collectors: Gealey and Douglas, 1939. Reference: N. L. Taliaferro, unpub. field notes dated June 6, 1939.

No. $1939-X$. In ctr. S1/2 sec. 20 , T. 25 S., R. 10 E. Fossils: mollusks. Collector: N. L. Taliaferro, 1939. Reference: N. L. Taliaferro, unpub. field notes dated June 6, 1939.

Adelaida quadrangle

USGS loc. M2693 (field No. 654141). On ridge SW. of road, $2,050 \mathrm{ft} \mathrm{N}$, $1,975 \mathrm{ft} \mathrm{W}$. of SE. cor. sec. 5, T. 26 S., R. 11 E. Fossils: mollusks. Age: Paleocene. Collectors: D. L. Durham and T. L. Winder, 1965. References: Durham, 1968b; Smith and Durham, 1968, p. A4. Remarks: fauna listed in text.

No. 3. About $600 \mathrm{ft} N$. of road on $120^{\circ} 50^{\prime}$ line of longitude, sec. 31, T. 25 S., R. 11 E. Fossils: mollusks. Collector: C. E. Van Gundy, 1931-32. Reference: Van Gundy, 1934, p. 57. Remarks: May be the same as the Acila locality listed by Schenck (1936, p. 48) at 1,900 ft S., $300 \mathrm{ft} \mathrm{E.} \mathrm{of} \mathrm{NW.} \mathrm{cor.} \mathrm{sec.} 31$.

No. 8. S. of San Marcos Creek, sec. 9, T. 26 S., R. 11 E. Fossils: mollusks. Collector: C. E. Van Gundy, 


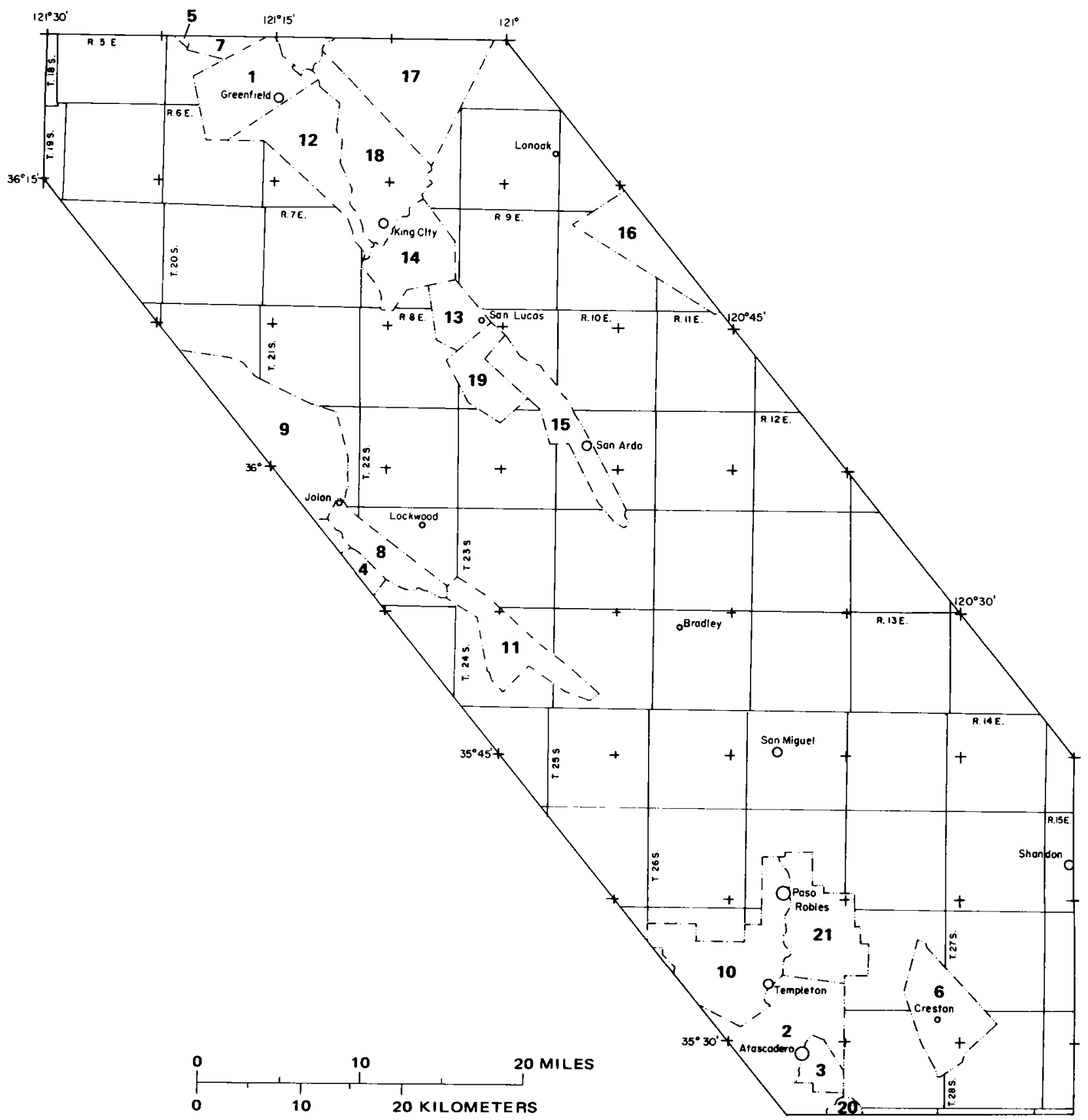

FIGURE 46.-Surveyed land boundaries in the southern Salinas Valley area. Corners of $71 / 2$-minute grid indicated by crosses (quadrangles identified in fig. 2). Land grants: 1, Arroyo Seco; 2, Asuncion; 3, Atascadero; 4, El Piojo; 5, Ex Mission Soledad; 6, Huerhuero; 7, Los Coches; 8,
Los Ojitos; 9, Milpitas; 10, Paso de Robles; 11, Pleyto; 12, Posa de los Ositos; 13, San Benito; 14, San Bernabe; 15, San Bernardo; 16, San Lorenzo (Randall); 17, San Lorenzo (Sanchez); 18, San Lorenzo (Soberanes); 19, San Lucas; 20, Santa Margarita; 21, Santa Ysabel.
Unnamed formation of Cretaceous and Paleocene age-Con. Adelaida quadrangle-Continued 1931-32. Reference: Van Gundy, 1934, p. 58.

No. 1939-S. In SE $1 / 4 \mathrm{SW} 1 / 4 \mathrm{NE} 1 / 4$ sec. 26 , T. $25 \mathrm{~S}$., R. 10 E. Fossils: mollusks. Collector: N. L. Taliaferro, 1939. Reference: N. L. Taliaferro, unpub. field notes dated May 31, 1939.
Reliz Canyon Formation

Reliz Canyon quadrangle

USGS loc. Mf482 (field No. 602-321). In creek bank, $250 \mathrm{ft} \mathrm{S.,} 575 \mathrm{ft} \mathrm{W}$. of NE. cor. sec. 35, T. $20 \mathrm{~S}$., R. 6 E. Fossils: foraminifers. Age and correlation: Eocene, probably Penutian Stage of Mallory (1959) (R. L. Pierce, oral commun., 1971). Collectors: D. L. Durham and C. L. Rice, 1960; R. L. Pierce and 
Reliz Canyon Formation-Continued

Reliz Canyon quadrangle-Continued

D. L. Durham, 1968. Reference: Durham, 1963, p. Q9. Remarks: Same as stop 7 of Society of Economic Paleontologists and Mineralogists field trip to Reliz Canyon, May 10, 1952; fauna listed in text.

Vaqueros Formation

Reliz Canyon quadrangle

USGS loc. M4007 (field No. 684043). On hillside, 2,050 ft N., 1,500 ft W. of SE. cor. sec. 26, T. 20 S., R. 6 E. Fossils: mollusks. Age: early Miocene. Collectors: D. L. Durham and J. A. Bartow, 1968.

LSJU loc. 2302 . On hillside, $1,800 \mathrm{ft}$ N., $200 \mathrm{ft} \mathrm{W}$. of SE. cor. sec. 15, T. 20 S., R. 6 E. Collector: R. R. Thorup, 1940. Reference: Thorup, 1942, p. 54 .

LSJU loc. 2303 . In bottom of gully, $1,450 \mathrm{ft} S ., 2,900 \mathrm{ft}$ E. of NW. cor. sec. 26 , T. 20 S., R. 6 E. Collector: R. R. Thorup, 1940. Reference: Thorup, 1942, p. 54

LSJU loc. 2304 . In gully, $2,600 \mathrm{ft}$ N., $1,000 \mathrm{ft}$ W. of SE. cor. sec. 26, T. 20 S., R. 6 E. Collector: R. R. Thorup, 1940. Reference: Thorup, 1942, p. 54.

LSJU loc. 2305. In gully, 2,000 ft N., 1,800 ft E. of SW. cor. sec. 23, T. 20 S., R. 6 E. Collector: R. R. Thorup, 1940. Reference: Thorup, 1942, p. 54 .

LSJU loc. 2306. On ridge, $2,800 \mathrm{ft} \mathrm{N}$., $1,000 \mathrm{ft} E$. of SW. cor. sec. 23, T. 20 S., R. 6 E. Collector: R. R. Thorup, 1940. Reference: Thorup, 1942, p. 54.

LSJU loc. 2307. Bold outcrops $1 / 5 \mathrm{mi}$ E. of creek, 1,200 ft S., $300 \mathrm{ft}$ E. of NW. cor. sec. 23, T. 20 S., R. 6 E. Collector: R. R. Thorup, 1940. Reference: Thorup, 1942, p. 54 .

LSJU loc. 2323. In gully, $1,300 \mathrm{ft} \mathrm{W}$. of SE. cor. sec. 15, T. 20 S., R. 6 E. Collector: R. R. Thorup, 1940. Reference: Thorup, 1942 , p. 55.

LSJU loc. 2324. At top of cliff, 1,200 ft N., 1,000 ft W. of SE. cor. sec. 15, T. 20 S., R. 6 E. Collector: R. R. Thorup, 1940. Reference: Thorup, 1942, p. 55.

LSJU loc. 2325. On hillside, $700 \mathrm{ft}$ N., 2,000 ft W. of SE. cor. sec. 15, T. 20 S., R. 6 E. Fossils: echinoids. Collector: R. R. Thorup, 1940. Reference: Thorup, 1942, p. 55.

LSJU loc. 2327, On ridge, $3,800 \mathrm{ft}$ N., $1,400 \mathrm{ft} \mathrm{W}$. of SE. cor. sec. 15, T. 20 S., R. 6 E. Fossils: mollusks. Collector: R. R. Thorup, 1940. Reference: Thorup, 1942 , p. 55.

LSJU loc. 2329. In tributary to Vaqueros Creek, 1,200 ft S., 3,200 ft W. of NE. cor. sec. 22 , T. 20 S., R. 6 E. Collector: R. R. Thorup, 1940. Reference: Thorup, 1942 , p. 56.

LSJU loc. 2330. In tributary to Vaqueros Creek, 800 $\mathrm{ft}$ S., $800 \mathrm{ft}$ E. of NW. cor. sec. 22, T. 20 S., R. 6 E. Fossils: mollusks. Collector: R. R. Thorup, 1940. Reference: Thorup, 1942, p. 56

LSJU loc. 2331. Near ctr. sec. 16, T. 20 S., R. 6 E. Collector: R. R. Thorup, 1940. Reference: Thorup, 1942 , p. 56

LSJU loc. 2332 . On hillside, $600 \mathrm{ft} S ., 3,500 \mathrm{ft} \mathrm{W}$. of NE. cor. sec. 22, T. 20 S., R. 6 E. Collector: R. R. Thorup, 1940. Reference: Thorup, 1942, p. 56.

LSJU loc. 2333. In bottom of gully, $1,200 \mathrm{ft}$ N., 1,500 ft E. of SW. cor. sec. 15, T. 20 S., R. 6 E. Fossils: mollusks. Collector: R. R. Thorup, 1940. Reference: Thorup, 1942, p. 56.

LSJU loc. 2376. On hillside, $2,500 \mathrm{ft} \mathrm{S.,} 1,800 \mathrm{ft}$ W. of
Vaqueros Formation-Continued

Reliz Canyon quadrangle - Continued

NE. cor. sec. 26, T. 20 S., R. 6 E. Collectors: R. R.

Thorup and H. G. Schenck, 1941. Reference: Thorup, 1942, p. 57.

LSJU loc. 2408. On hillside, $200 \mathrm{ft} \mathrm{N}$. of SW. cor. sec. 9, T. 20 S., R. 6 E. Collector: R. R. Thorup, 1940. Reference: Thorup, 1942, p. 57.

LSJU loc. 2409. On hillside, 1,500 ft N., 1,500 ft W. of SE. cor. sec. 4, T. 20 S., R. 6 E. Fossils: mollusks. Collectors: R. R. Thorup and others, 1941. Reference: Thorup, 1942 , p. 57.

LSJU loc. 2410 . On hillside, $1,750 \mathrm{ft}$ N., $1,330 \mathrm{ft} \mathrm{W}$. of SE. cor. sec. 4, T. 20 S., R. 6 E. Fossils: mollusks. Collectors: R. R. Thorup and others, 1941. Reference: Thorup, 1942, p. 57.

UC loc. 3675. North of road, along W. side of divide E. of Vaqueros Creek, N. of ctr. sec. 22, T. 20 S., R. 6 E., and across spurs to NE. on S. side of hills. Fossils: echinoids, mollusks, barnacles, brachiopods, and pinniped and cetacean bones. Reference: Loel and Corey, 1932, p. 117-120, 122. Remarks: same as LSJU loc. 2328 (Thorup, 1942, p. 56); UC loc. 3676 is "south extension of Dosinia reef of 3675 , on ridge $S$. from summit in road" (Loel and Corey, 1932, p. 122).

Bear Canyon quadrangle

USGS loc. M4074 (field No, 692031). On low ridge S. of Coleman Canyon, 17,500 ft S., 8,650 ft W. of NE. cor. quadrangle, Milpitas land grant. Fossils: echinoids and mollusks. Age: early Miocene. Collectors: W. O. Addicott and D. L. Durham, 1969. Remarks: near UC loc. A612, listed by Loel and Corey (1932, p. 121); fauna listed in text.

Cosio Knob quadrangle

UC loc. B-4916. On hillside, 1,200 ft S., 1,175 ft E. of NW. cor. sec. 17, T. 21 S., R. 7 E. Fossils: mollusks. Collector: R. M. Weidman, 1951-53. Reference: Weidman, 1958, p. 226.

UC loc. B-4917. On hillside, $1,500 \mathrm{ft}$ N., 1,350 ft W. of SE. cor. sec. 7, T. 21 S., R. 7 E. Fossils: mollusks. Collector: R. M. Weidman, 1951-53. Reference: Weidman, 1958, p. 226.

UC loc. B-4918. On hillside, $100 \mathrm{ft} \mathrm{N}$., $675 \mathrm{ft}$ E. of SW. cor. sec. 20 , T. 21 S., R. 7 E. Fossils: mollusks. Collector: R. M. Weidman, 1951-53. Reference: Weidman, 1958, p. 226.

Bryson quadrangle

USGS loc. M2673 (field No. 662048). In roadcut by Copperhead Creek, $250 \mathrm{ft} \mathrm{S}$., 1,500 ft E. of NW. cor. sec. 19, T. 24 S., R. 9 E. Fossils: mollusks. Age: early Miocene. Collectors: W. O. Addicott and D. L. Durham, 1966. Remarks: fauna listed in text; fossil locality in figure 38.

UC loc. A579. "South side Copperhead Cr. and Pleyto Road on end of spur SW of 955' B.M. 0.2 mile E. and 0.1 mile S. of NW. cor. Sec. 19, T. 24 S., R. 9 E." Fossils: mollusks (oysters). Reference: Loel and Corey, 1932, p. 118, 121.

UC loc. A582. "West of road at foot of spur, 0.4 mile $\mathbf{E}$. and 0.4 mile N. of SW. cor. Sec. 25, T. 24 S., R. 8 E." Fossils: mollusks (pelecypods). Reference: Loel and Corey, 1932, p. 117-119, 121.

UC loc. A583. "In creek bed east of road, head of 
Vaqueros Formation-Continued

Bryson quadrangle-Continued

Kavanaugh Creek, center of SE1/4 Sec. 25, T. 24 S., R. 8 E." Fossils: echinoids. Reference: Loel and Corey, 1932, p. 117, 120-121.

UC loc. A584. "At spring E. of road, 0.4 mile $S$. and 0.45 mile W. of NE. cor. Sec. 25, T. 24 S., R. 8 E." Fossils: mollusks (pectens). Reference: Loel and Corey, 1932, p. 118, 121.

UC loc. A585. "North side of end of spur just SW. of cross roads which is W. of Hesperia School, on section line * * * Also across road to NW." Fossils: echinoids, mollusks. Reference: Loel and Corey, 1932, p. 117-121.

UC loc. A586. "East side of road, NE. of Hesperia School, 0.2 mile N. and 0.2 mile W. of SE. cor. Sec. 24, T. 24 S., R. 8 E." Fossils: echinoids, mollusks (pelecypods). Reference: Loel and Corey, 1932, p. 117-118, 121.

UC loc. A587. "West side of road, south side of spur, 0.01 mile S. and 0.05 mile W. of NE. cor. Sec. 24, T. 24 S., R. 8 E." Fossils: echinoids, mollusks (pelecypods). Reference: Loel and Corey, 1932, p. 117118, 121. Remarks: same beds as UC locs. A589 and A590, according to Loel and Corey.

UC loc. A588. "West Copperhead Cr., on spur 0.3 mile E. and 0.01 mile N. of SW. cor. Sec. 13, T. 24 S., R. 8 E." Fossils: mollusks. Reference: Loel and Corey, 1932, p. 117-121.

UC loc. A589. "About 1.8 miles S. of A588, 0.2 mile E. and 0.01 mile $\mathrm{S}$. of NW. cor. Sec. 24, T. $24 \mathrm{~S}$., R. 8 E." Fossils: echinoids, mollusks (pelecypods). Reference: Loel and Corey, 1932, p. 117-119, 121.

UC loc. A590. "Southwest of Smith's Ranch. 0.08 mile S. and 0.08 mile E. of NW. cor. Sec. 15, T. 24 S., R. 8 E." Fossils: echinoids, mollusks. Reference: Loel and Corey, 1932, p. 117-118, 121.

No. 1939-BB. In SW1/4 SE1/4 sec. 20 , T. 24 S., R. 9 E. Fossils: mollusks, barnacles. Collector: N. L. Taliaferro, 1939. Reference: N. L. Taliaferro, unpub. field notes dated June 6, 1939.

Tierra Redonda Mountain quadrangle

USGS loc. M2670 (field No. 662023). On E. side of ridge about $1 \mathrm{mi} \mathrm{N}$. of lake behind Nacimiento Dam, $500 \mathrm{ft} \mathrm{N}$., $50 \mathrm{ft} \mathrm{W}$. of SE. cor. sec. 7, T. 25 S., R. 10 E. Fossils: mollusks. Age: early Miocene. Collector: D. L. Durham, 1966. Reference: Durham, 1968a, p. 11. Remarks: fossil locality in figure 41.

USGS loc. M2688 (field No. 654002). On hillside by ranch road about $11 / 4 \mathrm{mi} N$. of lake behind Nacimiento Dam, 2,800 ft S., $1,200 \mathrm{ft} \mathrm{W}$. of $\mathrm{NE}$. cor. sec. 7, T. 25 S., R. 10 E. Fossils: mollusks (turritellas). Age: early Miocene. Collectors: D. L. Durham and T. L. Winder, 1965. Reference: Durham, 1968a, p. 11. Remarks: fossil locality in figure 41.

USGS loc. M2689 (field No. 654011). On ridgetop about $11 / 4 \mathrm{mi} \mathrm{N}$. of lake behind Nacimiento Dam, $1,225 \mathrm{ft}$ N., 1,550 ft E. of SW. cor. sec. 12, T. $25 \mathrm{~S}$., R. 9 E. Fossils: mollusks. Age: early or middle Miocene. Collectors: D. L. Durham and T. L. Winder, 1965. Reference: Durham, 1968a, p. 11. Remarks: fossil locality in figure 41.

USGS loc. M2691 (field No. 654034). On ridge at head of south-flowing tributary to Nacimiento River, 325
Vaqueros Formation-Continued

Tierra Redonda Mountain quadrangle - Continued ft S., 1,675 ft E. of NW. cor. sec. 14, T. 25 S., R. 9 E. Fossils: mollusks (turritellas). Age: early Miocene. Collectors: D. L. Durham and T. L. Winder, 1965. Reference: Durham, 1968a, p. 11.

USGS loc. M2692 (field No. 654036). In cut on ranch road, $500 \mathrm{ft} \mathrm{S.,} 550 \mathrm{ft}$ W. of NE. cor. sec. 15, T. $25 \mathrm{~S}$., R. 9 E. Fossils: mollusks. Age: early Miocene. Collectors: W. O. Addicott and D. L. Durham, 1967. Reference: Durham, 1968a, p. 11.

USGS loc. M3242 (field No. 672056). On S. side of small knob on ridge $1 / 2 \mathrm{mi} \mathrm{S}$. of Tierra Redonda Mountain, $275 \mathrm{ft} \mathrm{N}$., $75 \mathrm{ft} \mathrm{W}$. of SE. cor. sec. 10, T. 25 S., R. 9 E. Fossils: mollusks. Age: early Miocene. Collectors: W. O. Addicott and D. L. Durham, 1967. Reference: Durham, 1968a, p. 11.

USGS loc. M3249 (field No. AC-TRM67-1). On hillside near abandoned barn, 2,525 ft N., $950 \mathrm{ft} \mathrm{W}$. of SE. cor. sec. 7, T. 25 S., R. 10 E. Fossils: mollusks. Age: early Miocene. Collectors: W. O. Addicott and D. L. Durham, 1967. Reference: Durham, 1968a, p. 11. Remarks: Probably about same beds at at LSJU loc. 677 noted by $H$. G. Schenck " 1 mile southeast of Bee Rock School" (unpub. field notes dated May 12, 1928); fossil locality in figure 41.

USGS loc. M3250 (field No. AC-TRM67-2). By trail on W. side of Tierra Redonda Mountain, $625 \mathrm{ft} S$., $800 \mathrm{ft}$ E. of NW. cor. sec. 10, T. 25 S., R. 9 E. Fossils: mollusks. Age: early Miocene. Collectors: W. O. Addicott and D. L. Durham, 1967. Reference: Durham, 1968a, p. 11. Remarks: fauna listed in text.

UC loc. A576. "In small canyon N. of NW. spur of Tierra Redondo Mountain, near quarter-section line of S. 1/2 Sec. 3, T. 25 S., R. 9 E." Fossils: mollusks. Reference: Loel and Corey, 1932, p. 117-121.

UC loc. A591. "S. of point in bend of road near $E$. side of Sec. 7, T. 25 S., R. 10 E., at about $1,200^{\prime}$ contour." Fossils: mollusks, echinoids, barnacles. Reference: Loel and Corey, 1932, p. 117-121.

No. 1939-R. On W. line of quadrangle in $\mathrm{E}^{1 / 4}$ of $\mathrm{NE} 1 / 4$ sec. 4, T. 25 S., R. 9 E., at elevation of 1,050-1,150 ft. Fossils: mollusks. Collector: N. L. Taliaferro, 1939. Reference: N. L. Taliaferro, unpub. field notes dated May 31, 1939.

Tierra Redonda Formation

Sycamore Flat quadrangle

USGS loc. M3244 (field No. 672069). In cut along dirt road, $1,000 \mathrm{ft} \mathrm{S}$., $2,750 \mathrm{ft}$ E. of NW. cor. sec. 30 , T. 18 S., R. 5 E. Fossils: mollusks. Age: Miocene. Collector: D. L. Durham, 1967. Reference: Durham, 1970, p. 9.

USGS loc. M3245 (field No. 672071). In creek bank, $1,450 \mathrm{ft} \mathrm{S}$., 4,350 ft E. of NW. cor. sec. $30, T .18 \mathrm{~S}$., R. 5 E. Fossils: mollusks. Age: Miocene or Pliocene. Collector: D. L. Durham, 1967. Reference: Durham, 1970, p. 9.

USGS loc. M3247 (field No. 672075). On hillside, $1,075 \mathrm{ft} \mathrm{S}$., $2,375 \mathrm{ft} \mathrm{E}$. of NW. cor. sec. 30 , T. $18 \mathrm{~S}$., R. 5 E. Fossils: mollusks. Age: early or middle Miocene. Collector: D. L. Durham, 1967. Reference: Durham, 1970, p. 9. Remarks: near loc. 1 of Schombel, which is $1,800 \mathrm{ft} \mathrm{S}$., 2,300 ft E. of NW. cor. sec. 30, T. 18 S., R. 5 E. (Schombel, 1940, p. 19). 
Tierra Redonda Formation-Continued

Sycamore Flat quadrangle-Continued

USGS loc. M3248 (field No. 672079). On ridge, 1,850 ft N., 3,950 ft W. of SE. cor. sec. 31, T. 18 S., R. 5 E. Fossils: mollusks (pectens). Age: middle Miocene. Collector: D. L. Durham, 1967. Reference: Durham, 1970, p. 9. Remarks: fauna listed in text.

USGS loc. M3705 (field No. 674043). In cut along dirt road, $400 \mathrm{ft} \mathrm{N}$., $500 \mathrm{ft} \mathrm{W}$. of SE. cor. sec. $32, T .18 \mathrm{~S}$., R. 5 E. Fossils: mollusks (pectens). Age: early or middle Miocene. Collector: D. L. Durham, 1967. Reference: Durham, 1970, p. 9. Remarks: near loc. 3 of Schombel, which is $50 \mathrm{ft} \mathrm{N}$., $300 \mathrm{ft}$ W. of SE. cor. sec. 32 , T. 18 S., R. 5 E. (Schombel, 1940, p. 19).

USGS loc. M3706 (field No. 674054). On ridge, 1,150 $\mathrm{ft}$ N., 2,000 ft W. of SE. cor. sec. 29, T. 18 S., R. $5 \mathrm{E}$. Fossils: mollusks. Age: Miocene, probably middle Miocene. Collector: D. L. Durham, 1967. Reference: Durham, 1970, p. 9.

USGS loc. Mf1015 (field No. 674053). On ridge, 1,350 $\mathrm{ft}$ N., 1,900 ft W. of SE. cor. sec. 29, T. 18 S., R. 5 E. Fossils: foraminifers. Age and correlation: Miocene, lower(?) Luisian Stage. Collector: D. L. Durham, 1967. Reference: Durham, 1970, p. 10.

No. 2. Along dirt road, 2,600 ft S., 1,250 ft W. of NE. cor. sec. 6, T. 19 S., R. 5 E. Fossils: mollusks. Collector: L. F. Schombel, 1938-1939. Reference: Schombel, 1940, p. 19.

Paraiso Springs quadrangle

USGS loc. M3707 (field No. 674114). On hillside, $1,800 \mathrm{ft}$ S., $550 \mathrm{ft}$ W. or NE. cor. sec. $31, T$. $18 \mathrm{~S}$., R. 6 E. Fossils: mollusks. Age: early or middle Miocene. Collector: D. L. Durham, 1967. Reference: Durham, 1970, p. 9.

USGS loc. M3708 (field No. 674145). On hillside, $1,800 \mathrm{ft} \mathrm{S}$., $2,775 \mathrm{ft}$ E. of NW. cor. sec. 31 , T. $18 \mathrm{~S}$., R. 6 E. Fossils: mollusks. Age: early or middle Miocene. Collector: D. L. Durham, 1967. Reference: Durham, 1970, p. 9.

No. 4. On hillside, $2,100 \mathrm{ft} \mathrm{N}$., $1,750 \mathrm{ft} \mathrm{W}$. of $S E$. cor. sec. 36, T. 18 S., R. 5 E. Fossils: mollusks. Collector: L. F. Schombel, 1938-39. Reference: Schombel, 1940, p. 19.

Lime Mountain quadrangle

USGS loc. M4187 (field No. 694001). Loose blocks of rock in creek from hillside above, $3,100 \mathrm{ft} S ., 2,050$ ft W. of NE. cor. sec. 7, T. 26 S., R. 10 E. Fossils: mollusks (pectens) and foraminifers (orbitoid). Age: early or middle Miocene. Collectors: D. L. Durham and R. J. McLaughlin, 1969. Remarks: located $150 \mathrm{ft} \mathrm{SW}$. of border of mapped area; at or near LSJU loc. 1155 (Taliaferro and Schenck, 1933, p. 75; Schenck and Childs, 1942, p. 17, 27).

USGS loc. M4199 (field No. ACA 69-1). Near crest of small knoll near ctr. sec. 7, T. 26 S., R. 10 E. Fossils: mollusks, foraminifers (orbitoid). Age: early or middle Miocene. Collectors: W. O. Addicott, D. L. Durham, and Kôichirô Masuda, 1970. Remarks: about $300 \mathrm{ft} \mathrm{SW}$. of border of mapped area; at or near LSJU loc. 1155 (Taliaferro and Schenck, 1933, p. 75, Schenck and Childs, 1942, p. $17,27)$; fauna listed in text.

LSJU loc. 2212. Behind barn, $1,300 \mathrm{ft} \mathrm{N}$., $500 \mathrm{ft} \mathrm{W}$. of SE. cor. sec. 7, T. 26 S., R. 10 E. Fossils: mollusks
Tierra Redonda Formation-Continued

Lime Mountain quadrangle-Continued (pectens). Reference: Schenck and Childs, 1942, p. 28.

UC loc. A574. "Coarse sandstone up gulch E. of White's ranch house, near SE. cor. Sec. 7, T. $26 \mathrm{~S}$., R. 10 E." Fossils: mollusks (pectens). Reference: Loel and Corey, 1932, p. 102-104.

York Mountain quadrangle

USGS loc. M3949. Along road on ridge between Jack Creek and Sheepcamp Creek, 16,200 ft S., 17,200 ft W. of NE. cor. quadrangle, Paso de Robles land grant. Fossils: mollusks (pectens). Age: early or middle Miocene. Collectors: B. M. Page, N. J. Silberling, and D. L. Jones, 1968.

USGS loc. M4200 (field No. ACA 69-2). Along ranch road, $21,425 \mathrm{ft} \mathrm{N}$., $16,350 \mathrm{ft} \mathrm{W}$. of $\mathrm{SE}$. cor. quadrangle, Paso de Robles land grant. Fossils: mollusks (pectens). Age: early or middle Miocene. Collectors: W. O. Addicott, D. L. Durham, and Kôichirô Masuda, 1970.

Templeton quadrangle

USGS loc. M4192 (field No. 694011). In railroad cut at Templeton, $16,625 \mathrm{ft} \mathrm{N}$., 13,150 ft E. of SW. cor. quadrangle, Paso de Robles land grant. Fossils: echinoids, mollusks (brachiopods, pelecypods), barnacles. Age: early or middle Miocene. Collectors: D. L. Durham and R. J. McLaughlin, 1969. Remarks: fauna listed in text.

Wilson Corner quadrangle

USGS loc. M3813 (field No. 682032). On hillside 1/2 mi E. of Indian Creek, $1,025 \mathrm{ft} \mathrm{N}$., 3,500 ft E. of SW. cor. sec. 29, T. 28 S., R. 15 E. Fossils: mollusks. Age: middle Miocene. Collector: D. L. Durham, 1968. Remarks: loc. 125 of Anderson and Martin (1914, p. 65) is probably on next hill to south; fauna listed in text.

USGS loc. M3814 (field No. 682044). Rock scattered in plowed field, about $1,800 \mathrm{ft} \mathrm{S}$., $1,500 \mathrm{ft} \mathrm{W}$. of NE. cor. sec. 25, T. 28 S., R. 14 E. Fossils: mollusks. Age: middle Miocene. Collector: D. L. Durham, 1968. Remarks: fauna listed in text.

Monterey Formation, Sandholdt Member

Sycamore Flat quadrangle

USGS loc. Mf955 (field No. 672002). On hillside, 600 $\mathrm{ft}$ N., 1,725 ft E. of SW. cor. sec. 36, T. 18 S., R. 5 E. Fossils: foraminifers. Age and correlation: Miocene, Luisian Stage. Collector: D. L. Durham, 1967. Reference: Durham, 1970, p. 16-17.

USGS loc. Mf956 (field No. 672003). On ridge crest, $325 \mathrm{ft} \mathrm{S.,} 700 \mathrm{ft}$ W. of NE. cor. sec. 2, T. $19 \mathrm{~S}$., R. 5 E. Fossils: foraminifers. Age and correlation: Miocene, Luisian Stage. Collector: D. L. Durham, 1967. Reference: Durham, 1970, p. 16-17.

USGS loc. Mf959 (field No. 672035). In roadcut, 2,450 $\mathrm{ft}$ S., $1,600 \mathrm{ft}$ E. of NW. cor. sec. 17, T. 19 S., R. 5 E. Fossils: foraminifers. Age and correlation: Miocene, upper Luisian Stage. Collector: D. L. Durham, 1967. Reference: Durham, 1970, p. 16-17.

USGS loc. Mf960 (field No. 672037). In roadcut, 950 ft N., 1,500 ft W. of SE, cor. sec. 7, T. 19 S., R. 5 E. Fossils: foraminifers. Age and correlation: Miocene, upper Luisian Stage. Collector: D. L. Durham, 1967. Reference: Durham, 1970, p. 16-17. 
Monterey Formation, Sandholdt Member-Continued Sycamore Flat quadrangle-Continued

USGS loc. Mf961 (field No. 672038). In roadcut, 900 ft S., 1,450 ft E. of NW. cor. sec. 7, T. 19 S., R. 5 E. Fossils: foraminifers. Age and correlation: Miocene, upper Luisian Stage. Collector: D. L. Durham, 1967. Reference: Durham, 1970, p. 16-17.

USGS loc. Mf962 (field No. 672039). In bank of Paloma Creek, 1,175 ft N., $150 \mathrm{ft} \mathrm{E.} \mathrm{of} \mathrm{SW.} \mathrm{cor.}$ sec. 6, T. 19 S., R. 5 E. Fossils: foraminifers. Age and correlation: Miocene, upper Luisian Stage. Collector: D. L. Durham, 1967. Reference: Durham, 1970, p. 16-17.

USGS loc. Mf963 (field No. 672041). In roadcut, $1,625 \mathrm{ft} \mathrm{S}$., 1,300 ft W. of NE. cor. sec. 1, T. 19 S., R. 4 E. Fossils: foraminifers. Age and correlation: Miocene, upper Luisian Stage. Collector: D. L. Durham, 1967. Reference: Durham, 1970, p. 16-17.

USGS loc. Mf964 (field No. 672044). In roadcut, $1,050 \mathrm{ft} \mathrm{S}$., $4,200 \mathrm{ft} \mathrm{W}$. of NE. cor. sec. $25, \mathrm{~T} .18 \mathrm{~S}$., R. 4 E. Fossils: foraminifers. Age and correlation: Miocene, upper Luisian Stage. Collector: D. L. Durham, 1967. Reference: Durham, 1970, p. 16-17. USGS loc. Mf965 (field No. 672046. In bank of Paloma Creek, $475 \mathrm{ft}$. S., 2,400 ft W. of NE. cor. sec. 1, T. 19 S., R. 4 E. Fossils: foraminifers. Age and correlation: Miocene, lower Luisian Stage. Collector: D. L. Durham, 1967. Reference: Durham, 1970, p. 16-17.

USGS loc. Mf966 (field No. 672057). In roadcut, 875 ft. S., 1,550 ft W. of NE. cor. sec. 25 , T. 18 S., R. 4 E. Fossils: foraminifers. Age and correlation: Miocene, Luisian Stage. Collector: D. L. Durham, 1967. Reference: Durham, 1970 , p. 16-17.

USGS loc. Mf967 (field No. 672058). On ridge crest, $2,000 \mathrm{ft}$. S., $625 \mathrm{ft} \mathrm{E.} \mathrm{of} \mathrm{NW.} \mathrm{cor.} \mathrm{sec.} 30$, T. $18 \mathrm{~S}$., R. 5 E. Fossils: foraminifers. Age: Miocene. Collector: D. L. Durham, 1967. Reference: Durham, 1970 , p. 16-17.

USGS loc. Mf968 (field No. 672072). In creek bank, $2,250 \mathrm{ft} \mathrm{S.,} \mathrm{3,725} \mathrm{ft} \mathrm{E.} \mathrm{of} \mathrm{NW.} \mathrm{cor.} \mathrm{sec.} 30$, T. $18 \mathrm{~S}$., R. 5 E. Fossils: foraminifers. Age and correlation: Miocene, upper Luisian Stage. Collector: D. L. Durham, 1967. Reference: Durham, 1970, p. 16-17.

USGS loc. Mf969 (field No. 672089). In streambank, $2,975 \mathrm{ft} \mathrm{N}$., 1,350 ft E. of SW. cor. sec. 1, T. $19 \mathrm{~S}$., R. 4 E. Fossils: foraminifers. Age and correlation: Miocene, upper Luisian Stage. Collector: D. L. Durham, 1967. Reference: Durham, 1970, p. 16-17.

USGS loc. Mf970 (field No. 672091). In streambank, $1,650 \mathrm{ft} \mathrm{N}$., 2,075 ft W. of SE. cor. sec. 1, T. $19 \mathrm{~S}$., R. 4 E. Fossils: foraminifers. Age and correlation: Miocene, upper Luisian Stage. Collector: D. L. Durham, 1967. Reference: Durham, 1970, p. 16-17.

USGS loc. Mf971 (field No. 672104). On ridge crest, $2,300 \mathrm{ft} \mathrm{N}$., $2,125 \mathrm{ft} \mathrm{W}$. of SE. cor. sec. 12 , T. $19 \mathrm{~S}$., R. 4 E. Fossils: foraminifers. Age and correlation: Miocene, Luisian Stage. Collector: D. L. Durham, 1967. References: Durham, 1970, p. 16-17.

USGS loc. Mf972 (field No. 672106). On ridge crest, $1,350 \mathrm{ft} \mathrm{N}$., $400 \mathrm{ft} \mathrm{W}$. of SE. cor. sec. 2, T. 19 S., R. 4 E. Fossils: foraminifers. Age and correlation: Miocene, upper Luisian Stage. Collector: D. L. Durham, 1967. Reference: Durham, 1970, p. 16-17.
Monterey Formation, Sandholdt Member-Continued

Sycamore Flat quadrangle-Continued

USGS loc. Mf1012 (field No. 674027). In roadcut, 900 ft. N., $450 \mathrm{ft} \mathrm{W.} \mathrm{of} \mathrm{SE.} \mathrm{cor.} \mathrm{sec.} \mathrm{33,} \mathrm{T.} 18$ S., R. $5 \mathrm{E}$. Fossils: foraminifers. Age and correlation: Miocene, upper Luisian Stage. Collector: D. L. Durham, 1967. Reference: Durham, 1970, p. 16-17.

USGS loc. Mf1013 (field No. 674033). On ridge crest, $1,650 \mathrm{ft} \mathrm{S}$., $1,950 \mathrm{ft}$ E. of NW. cor. sec. 33, T. $18 \mathrm{~S}$., R. 5 E. Fossils: foraminifers. Age: Miocene. Collector: D. L. Durham, 1967. Reference: Durham, 1970, p. 16-17.

USGS loc. Mf1014 (field No. 674038). On hillside, $650 \mathrm{ft} \mathrm{S}$., 1,850 ft E. of NW. cor. sec. 9, T. $19 \mathrm{~S}$., R. 5 E. Fossils: foraminifers. Age and correlation: Miocene, upper Luisian Stage. Collector: D. L. Durham, 1967. Reference: Durham, 1970, p. 16-17.

USGS loc. Mf1016 (field No. 674056). On ridge crest, $250 \mathrm{ft} \mathrm{N}$., $2,100 \mathrm{ft} \mathrm{W}$. of SE. cor. sec. 29 , T. $18 \mathrm{~S}$., R. 5 E. Fossils: foraminifers. Age and correlation: Miocene, Luisian Stage. Collector: D. L. Durham, 1967. Reference: Durham, 1970, p. 16-17.

USGS loc. Mf1017 (field No. 674059). In roadcut, $1,450 \mathrm{ft} \mathrm{S}$., $950 \mathrm{ft} \mathrm{W}$. of NE. cor. sec. 3, T. $19 \mathrm{~S}$., R. 5 E. Fossils: foraminifers. Age and correlation: Miocene lower(?) Luisian Stage. Collector: D. L. Durham, 1967. Reference: Durham, 1970, p. 16-17.

USGS loc. Mf1018 (field No. 674066). In streambank, $1,650 \mathrm{ft}$ N., $1,200 \mathrm{ft}$ E. of SW. cor. sec. 9, T. $19 \mathrm{~S}$., R. 5 E. Fossils: foraminifers. Age and correlation: Miocene, lower(?) Luisian Stage. Collector: D. L. Durham, 1967. Reference: Durham, 1970, p. 16-17. Paraiso Springs quadrangle

USGS loc. Mf921 (field No. 664092A). In roadcut, $2,400 \mathrm{ft} \mathrm{S}$., $550 \mathrm{ft} \mathrm{W}$. of NE. cor. sec. 6, T. $19 \mathrm{~S}$., R. 6 E. Fossils: foraminifers. Age: Miocene. Collector: D. L. Durham, 1966. Reference: Durham, 1970, p. 16-17.

USGS loc. Mf922 (field No. 664092). In roadcut, $2,400 \mathrm{ft} \mathrm{S}$., $900 \mathrm{ft}$ W. of NE. cor. sec. 6, T. $19 \mathrm{~S}$., R. 6 E. Fossils: foraminifers. Age and correlation: Miocene, Luisian Stage. Collector: D. L. Durham, 1966. Reference: Durham, 1970, p. 16-17.

USGS loc. Mf923 (field No. 664093). In roadcut, $2,800 \mathrm{ft} \mathrm{S}$., $750 \mathrm{ft}$ W. of NE. cor. sec. 6, T. $19 \mathrm{~S}$., R. 6 E. Fossils: foraminifers. Age and correlation: Miocene, Luisian Stage. Collector: D. L. Durham, 1966. Reference: Durham, 1970, p. 16-17.

USGS loc. Mf924 (field No. 664102). In roadcut, $2,175 \mathrm{ft} \mathrm{N}$., $725 \mathrm{ft} \mathrm{E}$. of SW. cor. sec. 6, T. $19 \mathrm{~S}$., R. 6 E. Fossils: foraminifers. Age and correlation: Miocene, lower Luisian Stage. Collector: D. L. Durham, 1966. Reference: Durham, 1970, p. 16-17. Junipero Serra Peak quadrangle

USGS loc. M2905 (field No. 3-B). On hillside, $1,300 \mathrm{ft}$ N., 1,650 ft E. of SW. cor. sec. 25 , T. 19 S., R. 5 E. Fossils: mollusks (brachiopods, pelecypods). Age: middle Miocene(?) Collector: R. L. Bendixen, 1966.

USGS loc. M2906 (field No. 4-B). On hillside, 1,400 ft N., 1,500 ft E. of SW. cor. sec. 25, T. 19 S., R. 5 E. Fossils: mollusks (pelecypods). Age and correlation: middle Miocene, "Temblor Stage." Collector: R. L. Bendixen, 1966.

USGS loc. Mf1020 (field No. 674147). In roadcut, 
Monterey Formation, Sandholdt Member-Continued Junipero Serra Peak quadrangle-Continued $2,125 \mathrm{ft} \mathrm{N}$., 1,400 ft E. of SW. cor. sec. 31, T. $19 \mathrm{~S}$. R. 5 E. Fossils: foraminifers. Age and correlation: Miocene, Saucesian or lower Relizian Stage. Collector: D. L. Durham, 1967.

USGS loc. Mf1165 (field No. 681002). On ridge crest, $2,850 \mathrm{ft} \mathrm{S.,} 25 \mathrm{ft}$ E. of NW. cor. sec. 31 , T. $19 \mathrm{~S}$., R. 5 E. Fossils: foraminifers. Age and correlation: Miocene, Relizian or lower Luisian Stage. Collector: D. L. Durham, 1968.

USGS loc. Mf1166 (field No. 683003). On hillside, $2,475 \mathrm{ft} \mathrm{N}$., $1,825 \mathrm{ft} \mathrm{W}$. of SE. cor. sec. $36, T$. $19 \mathrm{~S}$., R. 4 E. Fossils: foraminifers. Age and correlation: Miocene, lower Relizian Stage. Collector: D. L. Durham, 1968. Remarks: fauna listed in text.

USGS loc. Mf1167 (field No. 681004). On ridge crest, $1,175 \mathrm{ft} \mathrm{S}$., $775 \mathrm{ft} \mathrm{W}$. of NE. cor. sec. $36, \mathrm{~T} .19 \mathrm{~S}$., R. 4 E. Fossils: foraminifers. Age and correlation: Miocene, Relizian(?) Stage. Collector: D. L. Durham, 1968.

USGS loc. Mf1168 (field No. 681005). In roadcut, $750 \mathrm{ft} \mathrm{N}$., $150 \mathrm{ft} \mathrm{W}$. of SE. cor. sec. 31, T. $19 \mathrm{~S}$., R. 5 E. Fossils: foraminifers. Age and correlation: Miocene, lower Relizian Stage. Collector: D. L. Durham, 1968.

USGS loc. Mf1169 (field No. 682003). In bank of Arroyo Seco, $75 \mathrm{ft} \mathrm{N}$., $850 \mathrm{ft}$ W. of SE. cor. sec. $31, \mathrm{~T}$. 19 S., R. 5 E. Fossils: foraminifers. Age and correlation: Miocene, Saucesian or Relizian Stage. Collector: D. L. Durham, 1968.

USGS loc. Mf1170 (field No. 682009). In bank of Horse Canyon creek, 2,450 ft S., $950 \mathrm{ft} \mathrm{W}$. of NE. cor. sec. 34, T. 19 S., R. 5 E. Fossils: foraminifers. Age and correlation: Miocene, Saucesian or lower Relizian Stage. Collector: D. L. Durham, 1968.

USGS loc. Mf1171 (field No. 682010). In bank of Horse Canyon creek, $1,800 \mathrm{ft} \mathrm{S}$., 1,150 ft W. of NE. cor. sec. 34, T. 19 S., R. 5 E. Fossils: foraminifers. Age and correlation: Miocene, lower Relizian Stage. Collector: D. L. Durham, 1968.

USGS loc. Mf1172 (field No. 682011). In bank of Horse Canyon creek, $1,150 \mathrm{ft} \mathrm{S}$., 1,625 ft W. of NE. cor. sec. 34, T. 19 S., R. 5 E. Fossils: foraminifers. Age and correlation: Miocene, lower Relizian Stage. Collector: D. L. Durham, 1968.

USGS loc. Mf1173 (field No. 682012). In bank of Horse Canyon creek, $50 \mathrm{ft}$ N., $1,725 \mathrm{ft}$ W. of SE. cor. sec. 27, T. 19 S., R. 5 E. Fossils: foraminifers. Age and correlation: Miocene, lower Relizian Stage. Collector: D. L. Durham, 1968.

USGS loc. Mf1174 (field No. 682013). In roadcut, $1,500 \mathrm{ft}$ S., $1,900 \mathrm{ft}$ E. of NW. cor. sec. 33, T. $19 \mathrm{~S}$., R. 5 E. Fossils: foraminifers. Age and correlation: Miocene, Relizian(?) Stage. Collector: D. L. Durham, 1968.

USGS loc. Mf1175 (field No. 682014). In bank of Arroyo Seco, $1,150 \mathrm{ft} \mathrm{S}$., $200 \mathrm{ft} \mathrm{W}$. of NE. cor. sec. 32, T. 19 S., R. 5 E. Fossils: foraminifers. Age: middle Miocene. Collector: D. L. Durham, 1968.

Reliz Canyon quadrangle

USGS loc. Mf1461 (field No. 692054). On hillside, $1,625 \mathrm{ft} \mathrm{S.,} \mathrm{1,925} \mathrm{ft} \mathrm{W.} \mathrm{of} \mathrm{NE.} \mathrm{cor.} \mathrm{sec.} \mathrm{14,} \mathrm{T.} 20 \mathrm{~S}$., R. 6 E. Fossils: foraminifers. Age and correlation:
Monterey Formation, Sandholdt Member-Continued

Reliz Canyon quadrangle--Continued

Miocene, Relizian Stage. Collector: D. L. Durham, 1969.

USGS loc. Mf1462 (field No. 692055). On hillside, $1,425 \mathrm{ft} \mathrm{S.,} 2,025 \mathrm{ft} \mathrm{W}$. of NE. cor. sec. 14, T. $20 \mathrm{~S}$., R. 6 E. Fossils: foraminifers. Age and correlation: Miocene, probably upper Relizian Stage. Collector: D. L. Durham, 1969.

USGS loc. Mf1463 (field No. 692056). On hillside, $1,200 \mathrm{ft} \mathrm{S}$., $2,150 \mathrm{ft} \mathrm{W}$. of NE. cor. sec. $14, T .20 \mathrm{~S}$., R. 6 E. Fossils: foraminifers. Age and correlation: Miocene, Luisian Stage. Collector: D. L. Durham, 1969.

USGS loc. Mf1464 (field No. 692057). On ridge crest, $1,000 \mathrm{ft} \mathrm{S}$., $2,325 \mathrm{ft} \mathrm{W}$. of NE. cor. sec. 14, T. $20 \mathrm{~S}$., R. 6 E. Fossils: foraminifers. Age and correlation: Miocene, lower(?) Luisian Stage. Collector: D. L. Durham, 1969.

USGS loc. Mf1465 (field No. 692058). On ridge crest, $900 \mathrm{ft} \mathrm{S}$., $2,500 \mathrm{ft} \mathrm{W}$. of NE. cor. sec. 14, T. $20 \mathrm{~S}$., R. 6 E. Fossils: foraminifers. Age and correlation: Miocene, lower Luisian Stage. Collector: D. L. Durham, 1969. Remarks: fauna listed in text.

USGS loc. Mf1466 (field No. 692059). On ridge crest, $750 \mathrm{ft} \mathrm{S}$., $2,725 \mathrm{ft} \mathrm{W}$. of NE. cor. sec. 14, T. $20 \mathrm{~S}$., R. 6 E. Fossils: foraminifers. Age and correlation: Miocene, lower Luisian Stage. Collector: D. L. Durham, 1969.

USGS loc. Mf1467 (field No. 692060). On ridge crest, $550 \mathrm{ft} \mathrm{S}$., $3,025 \mathrm{ft} \mathrm{W}$. of NE. cor. sec. 14, T. $20 \mathrm{~S}$., R. 6 E. Fossils: foraminifers. Age and correlation: Miocene, upper Luisian Stage. Collector: D. L. Durham, 1969.

USGS loc. Mf1468 (field No. 692061). On hillside, $375 \mathrm{ft} \mathrm{S}$., 3,150 ft W. of NE. cor. sec. 14, T. $20 \mathrm{~S}$., R. 6 E. Fossils: foraminifers. Age and correlation: Miocene, upper Luisian Stage. Collector: D. L. Durham, 1969

USGS loc. Mf1469 (field No. 692062). On hillside, $150 \mathrm{ft} \mathrm{S.,} \mathrm{3,175} \mathrm{ft} \mathrm{W.} \mathrm{of} \mathrm{NE.} \mathrm{cor.} \mathrm{sec.} \mathrm{14,} \mathrm{T.} 20 \mathrm{~S}$., R. 6 E. Fossils: foraminifers. Age and correlation: Miocene, Luisian Stage. Collector: D. L. Durham, 1969.

USGS loc. Mf1470 (field No. 692063). On hillside, $1,850 \mathrm{ft} \mathrm{S.,} \mathrm{3,000} \mathrm{ft} \mathrm{W.} \mathrm{of} \mathrm{NE.} \mathrm{cor.} \mathrm{sec.} \mathrm{14,} \mathrm{T.} 20 \mathrm{~S}$., R. 6 E. Fossils: foraminifers. Age and correlation: Miocene, Relizian Stage. Collector: D. L. Durham, 1969.

USGS loc. Mf1471 (field No. 692064). On hillside, $2,200 \mathrm{ft} \mathrm{S}$., $2,775 \mathrm{ft} \mathrm{W}$. of NE. cor. sec. 14, T. $20 \mathrm{~S}$., R. 6 E. Fossils: foraminifers. Age and correlation: Miocene, Relizian Stage. Collector: D. L. Durham, 1969.

USGS loc. Mf1472 (field No. 692065). On hillside, $2,375 \mathrm{ft}$ S., $2,650 \mathrm{ft} \mathrm{W}$. of NE. cor. sec. 14, T. $20 \mathrm{~S}$., R. 6 E. Fossils: foraminifers. Age and correlations: Miocene, Relizian Stage. Collector: D. L. Durham, 1969.

USGS loc. Mf1477 (field No. 592-283). On hillside, $1,750 \mathrm{ft}$ S., $2,075 \mathrm{ft} \mathrm{E}$. of NW. cor. sec. $25, \mathrm{~T} .20 \mathrm{~S}$., R. 6 E. Fossils: foraminifers. Age and correlation: Miocene, lower Relizian Stage. Collector: D. L. Durham, 1959. 
Monterey Formation, Sandholdt Member-Continued Reliz Canyon quadrangle-Continued

USGS loc. Mf1478 (field No. 592-410). In cut on ranch road, $125 \mathrm{ft} \mathrm{S.,} 150 \mathrm{ft}$ E. of NW. cor. sec. 30 , T. 20 S., R. 7 E. Fossils: foraminifers. Age and correlation: Miocene, probably Relizian or lower Luisian Stage. Collector: D. L. Durham, 1959.

USGS loc. Mf1481 (field No. 694013). In creek bank, $2,200 \mathrm{ft} \mathrm{N}$., $1,800 \mathrm{ft}$ W. of SE. cor. sec. 14, T. $20 \mathrm{~S}$., R. 6 E. Fossils: foraminifers. Age and correlation: Miocene, lower(?) Saucesian Stage. Collector: D. L. Durham, 1969.

USGS loc. Mf1482 (field No. 694014). In creek bank, $2,300 \mathrm{ft}$ N., $1,700 \mathrm{ft}$ W. of SE. cor. sec. 14, T. $20 \mathrm{~S}$., R. 6 E. Fossils: foraminifers. Age and correlation: Miocene, upper(?) Saucesian Stage. Collector: D. L. Durham, 1969. Remarks: fauna listed in text. USGS loc. Mf1483 (field No. 694015). In creek bank, $2,775 \mathrm{ft} \mathrm{N}$., $1,150 \mathrm{ft} \mathrm{W}$. of SE. cor. sec. 14, T. $20 \mathrm{~S}$., R. 6 E. Fossils: foraminifers. Age and correlation: Miocene, lower Relizian Stage. Collector: D. L. Durham, 1969. Remarks: fauna listed in text.

USGS loc. Mf1484 (field No. 694016). In creek bank, $2,775 \mathrm{ft} \mathrm{N}$., $825 \mathrm{ft} \mathrm{W}$. of SE. cor. sec. 14, T. $20 \mathrm{~S}$., R. 6 E. Fossils: foraminifers. Age and correlation: Miocene, upper(?) Relizian Stage. Collector: D. L. Durham, 1969.

USGS loc. Mf1485 (field No. 694017). In creek bank, $2,900 \mathrm{ft} \mathrm{N}$., $375 \mathrm{ft} \mathrm{W}$. of SE. cor. sec. 14, T. $20 \mathrm{~S}$., R. 6 E. Fossils: foraminifers. Age and correlation: Miocene, lower (?) Luisian Stage. Collector: D. L. Durham, 1969.

USGS loc. Mf1486 (field No. 694018). In creek bed, $3,350 \mathrm{ft} \mathrm{N}$., $250 \mathrm{ft} \mathrm{W}$. of SE. cor. sec. $14, \mathrm{~T} .20 \mathrm{~S}$., R. 6 E. Fossils: foraminifers. Age and correlation: Miocene, upper Luisian Stage. Collector: D. L. Durham, 1969.

USGS loc. Mf1487 (field No. 694019). In creek bank, $3,350 \mathrm{ft} \mathrm{N}$., $75 \mathrm{ft} \mathrm{W}$. of SE. cor. sec. 14, T. $20 \mathrm{~S}$., R. 6 E. Fossils: foraminifers. Age and correlation: Miocene, Luisian Stage. Collector: D. L. Durham, 1969.

USGS loc. Mf1496 (field No. 692020). On hillside, $3,250 \mathrm{ft} \mathrm{N}$., $400 \mathrm{ft}$ E. of SW. cor. sec. 14, T. $20 \mathrm{~S}$., R. 6 E. Fossils: foraminifers. Age and correlation: Miocene, lower Relizian Stage. Collector: D. L. Durham, 1969.

USGS loc. Mf1497 (field No. 594-191). On hillside, $1,400 \mathrm{ft} \mathrm{N}$., $1,300 \mathrm{ft} \mathrm{W}$. of SE. cor. sec. $10, \mathrm{~T} .20 \mathrm{~S}$., R. 6 E. Fossils: foraminifers. Age and correlation: Miocene, upper Luisian Stage. Collector: D. L. Durham, 1959. Remarks: fauna listed in text.

USGS loc. Mf1502 (field No. 702001A). In cut on ranch road, $325 \mathrm{ft}$ N., $2,600 \mathrm{ft}$ E. of $S W$. cor. sec. 30 , T. 20 S., R. 7 E. Fossils: foraminifers. Age and correlation: Miocene, lower Saucesian Stage. Collector: D. L. Durham, 1970.

Thompson Canyon quadrangle

USGS loc. Mf1475 (field No. 584-148). In cut on ranch road in Thompson Canyon, $150 \mathrm{ft} S ., 2,325$ ft E. of NW. cor. sec. 32, T. 20 S., R. 7 E. Fossils: foraminifers. Age and correlation: Miocene, upper Luisian Stage. Collectors: D. L. Durham and R. P. Hunter, 1958.
Monterey Formation, Sandholdt Member-Continued Thompson Canyon quadrangle-Continued

USGS loc. Mf1476 (field No. 584-246). In cut on ranch road in Thompson Canyon, $425 \mathrm{ft} S ., 1,875$ ft E. of NW. cor. sec. 32, T. 20 S., R. 7 E. Fossils: foraminifers. Age and correlation: Miocene, lower(?) Luisian Stage. Collectors: D. L. Durham and R. P. Hunter, 1958.

USGS loc. Mf1498 (field No. 692022). In roadcut in Pine Canyon, $250 \mathrm{ft} \mathrm{S}$., 2,350 ft E. of NW. cor. sec. 4, T. 21 S., R. 7 E. Fossils: foraminifers. Age and correlation: Miocene, Relizian Stage. Collector: D. L. Durham, 1969.

USGS loc. Mf1503 (field No. 702001B). On hillside, $450 \mathrm{ft} \mathrm{N}$., $2,300 \mathrm{ft}$ W. of SE. cor. sec. 30, T. $20 \mathrm{~S}$., R. 7 E. Fossils: foraminifers. Age and correlation: Miocene, upper Saucesian or Relizian Stage. Collector: D. L. Durham, 1970.

USGS loc. Mf1504 (field No. 702001C). On hillside, $500 \mathrm{ft} \mathrm{N}$., $2,150 \mathrm{ft} \mathrm{W}$. of SE. cor. sec. 30, T. $20 \mathrm{~S}$., R. 7 E. Fossils: foraminifers. Age and correlation: Miocene, upper(?) Relizian. Collector: D. L. Durham, 1970.

USGS loc. Mf1505 (field No. 702001D). On hillside, $600 \mathrm{ft} \mathrm{N}$., $1,900 \mathrm{ft} \mathrm{W}$. of SE. cor. sec. 30, T. $20 \mathrm{~S}$., R. 7 E. Fossils: foraminifers. Age and correlation: Miocene, Relizian Stage. Collector: D. L. Durham, 1970.

USGS loc. Mf1507 (field No. 702001E). On hilltop, $825 \mathrm{ft} \mathrm{N}$., $1,900 \mathrm{ft} \mathrm{W}$. of SE. cor. sec. 30, T. $20 \mathrm{~S}$., R. 7 E. Fossils: foraminifers. Age and correlation: Miocene, lower Luisian Stage. Collector: D. L. Durham, 1970.

USGS loc. Mf1508 (field No. 702001G). On ridge crest, $1,675 \mathrm{ft} \mathrm{N}$., $1,825 \mathrm{ft} \mathrm{W}$. of $S E$. cor. sec. $30, T$. 20 S., R. 7 E. Fossils: foraminifers. Age and correlation: Miocene, upper Luisian Stage. Collector: D. L. Durham, 1970.

USGS loc. Mf1509 (field No. 702001H). On ridge crest, $2,100 \mathrm{ft} \mathrm{N}$., $1,625 \mathrm{ft} \mathrm{W}$. of $\mathrm{SE}$. cor. sec. $30, \mathrm{~T}$. 20 S., R. 7 E. Fossils: foraminifers. Age and correlation: Miocene, upper Luisian Stage. Collector: D. L. Durham, 1970.

USGS loc. Mf1510 (field No. 702001I). On ridge crest, $2,275 \mathrm{ft} \mathrm{N}$., 1,550 ft W. of SE. cor. sec. 30, T. 20 S., R. 7 E. Fossils: foraminifers. Age and correlation: Miocene, Luisian Stage. Collector: D. L. Durham, 1970.

Bear Canyon quadrangle

USGS loc. Mf1493 (field No. 692008). On hillside, $200 \mathrm{ft}$. N., 3,375 ft W. of SE. cor. sec. 24, T. $21 \mathrm{~S}$., R. 6 E. Fossils: foraminifers. Age and correlation: Miocene, Luisian Stage. Collector: D. L. Durham, 1969.

USGS loc. Mf1494 (field No. 692009). In creek bank, $17,450 \mathrm{ft} \mathrm{S}$., $18,025 \mathrm{ft} \mathrm{W}$. of $\mathrm{NE}$. cor. quadrangle, Milpitas land grant. Fossils: foraminifers. Age and correlation: Miocene, Relizian or Luisian Stage. Collector: D. L. Durham, 1969.

USGS loc. Mf1495 (field No. 692013). On hillside, $21,350 \mathrm{ft} \mathrm{N}$., $12,250 \mathrm{ft} \mathrm{W}$. of SE. cor. quadrangle, Milpitas land grant. Fossils: foraminifers. Age and correlation: Miocene, lower(?) Luisian Stage. Collector: D. L. Durham, 1969. 
Monterey Formation, Sandholdt Member-Continued Cosio Knob quadrangle

USGS loc. Mf481 (field No. 584-31). On ridge crest, $1,850 \mathrm{ft}$ S., $1,950 \mathrm{ft}$ E. of NW. cor. sec. $17, T .21 \mathrm{~S}$., R. 7 E. Fossils: foraminifers. Age and correlation: Miocene, Relizian or lower Luisian Stage. Collectors: D. L. Durham and R. P. Hunter, 1958. Reference: Durham, 1964, p. H12.

USGS loc. Mf629 (field No. S-11). On hillside, 3,200 ft N., 3,400 ft W. of SE. cor. sec. 17, T. 21 S., R. 7 E. Fossils: foraminifers. Age and correlation: Miocene, upper Relizian or lower Luisian Stage. Collectors: D. L. Durham and D. C. Wiese, 1962.

Bryson quadrangle

USGS loc. Mf902 (field No. 663002). In roadcut, 100 ft N., 2,150 ft W. of SE. cor. sec. 18, T. 24 S., R 9 E. Fossils: foraminifers. Age and correlation: Miocene, upper Saucesian Stage. Collector: D. L. Durham, 1966. Remarks: fauna listed in text; fossil locality in figure 38.

USGS loc. Mf903 (field No. 663003). In roadcut, 450 ft N., 1,850 ft W. of SE. cor. sec. 18, T. 24 S., R. 9 E. Fossils: foraminifers. Age and correlation: Miocene, Saucesian Stage. Collector: D. L. Durham, 1966. Remarks: fossil locality in figure 38.

USGS loc. Mf925 (field No. 664002). In roadcut, $2,900 \mathrm{ft}$ N., $1,800 \mathrm{ft} \mathrm{W}$. of SE. cor. sec. 18, T. $24 \mathrm{~S}$., R. 9 E. Fossils: foraminifers. Age and correlation: Miocene, lower Luisian Stage. Collector: D. L. Durham, 1966. Remarks: fauna listed in text; fossil locality in figure 38.

USGS loc. Mf926 (field No. 664015). On hillside, $2,725 \mathrm{ft} \mathrm{S}$., $4,600 \mathrm{ft}$ W. of NE. cor. sec. 18 , T. $24 \mathrm{~S}$., R. 9 E. Fossils: foraminifers. Age and correlation: Miocene, Saucesian Stage. Collector: D. L. Durham, 1966. Remarks: fossil locality in figure 38.

USGS loc. Mf1473 (field No. 692023). On dirt road, $450 \mathrm{ft} \mathrm{N}$., 2,550 ft W. of SE. cor. sec. 10, T. $24 \mathrm{~S}$., R. 8 E. Fossils: foraminifers. Age and correlation: Miocene, lower Relizian Stage. Collector: D. L. Durham, 1969. Remarks: fauna listed in text.

USGS loc. Mf1474 (field No. 692024). On dirt road, $700 \mathrm{ft}$. S., $300 \mathrm{ft}$ E. of NW. cor. sec. 14, T. $24 \mathrm{~S}$., R. 8 E. Fossils: foraminifers. Age and correlation: Miocene, upper(?) Relizian Stage. Collector: D. L. Durham, 1969.

USGS loc. Mf1475 (field No. 692025). In cut on dirt road, $4,000 \mathrm{ft} \mathrm{N}$., $2,000 \mathrm{ft} W$. of $S E$. cor. sec. $8, T$. $24 \mathrm{~S}$., R. $8 \mathrm{E}$., $1 / 2 \mathrm{mi} \mathrm{SW}$. of border of mapped area. Fossils: foraminifers. Age and correlation: Miocene, upper(?) Relizian Stage. Collector: D. L. Durham, 1969. Remarks: very near the base of exposed Sandholdt Member.

Tierra Redonda Mountain quadrangle

USGS loc. Mf639 (field No. 624421). In bluff along San Antonio River, 4,425 ft S., 2,625 ft W. of NE. cor. sec. 19, T. 24 S., R. 10 E. Fossils: foraminifers. Age and correlation: Miocene, upper Luisian Stage. Collector: D. L. Durham, 1962. Reference: Durham, 1968a, table 3. Remarks: fossil locality in figure 39.

USGS loc. Mf640 (field No. 624422). In bluff along San Antonio River, 4,400 ft S., 2,650 ft W. of NE. cor. sec. 19, T. 24 S., R. 10 E. Fossils: foraminifers.
Monterey Formation, Sandholdt Member-Continued Tierra Redonda Mountain quadrangle-Continued Age and correlation: Miocene, upper Luisian Stage. Collector: D. L. Durham, 1962. Reference: Durham, 1968a, table 3. Remarks: fossil locality in figure 39.

USGS loc. Mf641 (field No. 624441). In roadcut, $13,500 \mathrm{ft} \mathrm{S}$., $6,250 \mathrm{ft}$ E. of NW. cor. quadrangle, Pleyto land grant. Fossils: foraminifers. Age and correlation: Miocene, upper Luisian Stage. Collectors: D. L. Durham and D. C. Wiese, 1962. Reference: Durham, 1968a, table 3.

USGS loc. Mf642 (field No. 624444). In creekbed, $12,475 \mathrm{ft} \mathrm{S}$., $10,550 \mathrm{ft} \mathrm{E}$. of $\mathrm{NW}$. cor. quadrangle, Pley to land grant. Fossils: foraminifers. Age and correlation: Miocene, upper Luisian Stage. Collector: D. L. Durham, 1962. Reference: Durham, 1968a, table 3.

USGS loc. Mf643 (field No. 624447). On ridge crest, $12,575 \mathrm{ft} \mathrm{S}$., $6,275 \mathrm{ft} \mathrm{E}$. of $\mathrm{NW}$. cor. quadrangle, Pleyto land grant. Fossils: foraminifers. Age and correlation: Miocene, upper Luisian Stage. Collector: D. L. Durham, 1962. Reference: Durham, 1968a, table 3.

USGS loc. Mf644 (field No. W692). On hillside, 12,500 ft S., 5,300 ft E. of NW. cor. quadrangle, Pleyto land grant. Fossils: foraminifers. Age and correlation: Miocene, upper Luisian Stage. Collector: D. C. Wiese, 1962. Reference: Durham, 1968a, table 3.

USGS loc. Mf778 (field No. 634011). On ridgetop, $20,500 \mathrm{ft} \mathrm{S}$., $15,400 \mathrm{ft} \mathrm{E}$. of NW. cor. quadrangle, Pleyto land grant. Fossils: foraminifers. Age and correlation: Miocene, upper Luisian Stage. Collector: D. L. Durham, 1963. Reference: Durham, 1968a, table 3.

USGS loc. Mf779 (field No. 634017). In bank of Harris Creek, $375 \mathrm{ft} \mathrm{N}$., 1,300 ft E. of SW. cor. sec. 25, T. 24 S., R. 9 E. Fossils: foraminifers. Age and correlation: Miocene, Luisian Stage. Collector: D. L. Durham, 1963. Reference: Durham, 1968a, table 3.

USGS loc. Mf780 (field No. 634027). On ridgetop, $3,675 \mathrm{ft} \mathrm{N}$., $675 \mathrm{ft} \mathrm{E}$. of SW. cor. sec. 32 , T. $24 \mathrm{~S}$., R. 10 E. Fossils: foraminifers. Age and correlation: Miocene, Luisian Stage. Collector: D. L. Durham, 1963. Reference: Durham, 1968a, table 3. Remarks: fossil locality in figure 39 .

USGS loc. Mf781 (field No. 634049). In bluff along San Antonio River, $22,200 \mathrm{ft} \mathrm{S.,} 12,450 \mathrm{ft} \mathrm{W}$. of NE. cor. quadrangle, Pleyto land grant. Fossils: foraminifers. Age and correlation: Miocene, upper Luisian Stage. Collector: D. L. Durham, 1963. Reference: Durham, 1968a, table 3. Remarks: fossil locality in figure 39.

USGS loc. Mf782 (field No. 634056). In bank of San Antonio River, 23,000 ft S., 14,350 ft W. of NE. cor. quadrangle, Pleyto land grant. Fossils: foraminifers. Age and correlation: Miocene, Luisian Stage. Collector: D. L. Durham, 1963. Reference: Durham, 1968a, table 3. Remarks: fossil locality in figure 39.

USGS loc. Mf783 (field No. 634062). In bank of San Antonio River, 24,350 ft S., 8,800 ft W. of NE. cor. quadrangle, Pleyto land grant. Fossils: foraminifers. Age and correlation: Miocene, Luisian Stage. Col- 
Monterey Formation, Sandholdt Member-Continued

Tierra Redonda Mountain quadrangle-Continued lector: D. L. Durham, 1963. Reference: Durham, 1968a, table 3. Remarks: fossil locality in figure 39.

USGS loc. Mf784 (field No. 634067). On hillside, $20,075 \mathrm{ft} \mathrm{S}$., $20,025 \mathrm{ft} \mathrm{W}$. of NE. cor. quadrangle, Pleyto land grant. Fossils: foraminifers. Age and correlation: Miocene, Luisian Stage. Collector: D. L. Durham, 1963. Reference: Durham, 1968a, table 3. Remarks: fossil locality in figure 39 .

USGS loc. Mf785 (field No. 634068). In roadcut, $18,200 \mathrm{ft} \mathrm{S}$., $20,625 \mathrm{ft} \mathrm{W}$. of NE. cor. quadrangle, Pleyto land grant. Fossils: foraminifers. Age and correlation: Miocene, lower Luisian Stage. Collector: D. L. Durham, 1963, 1965. Reference: Durham, 1968a, table 3. Remarks: fossil locality in figure 39.

USGS loc. Mf786 (field No. 634071). In roadcut, $16,000 \mathrm{ft} \mathrm{S}$., $6,300 \mathrm{ft} \mathrm{E}$. of $\mathrm{NW}$. cor. quadrangle, Pleyto land grant. Fossils: foraminifers. Age and correlation: Miocene, Luisian Stage. Collector: D. L. Durham, 1963. Reference: Durham, 1968a, table 3.

USGS loc. Mf787 (field No. 634103). On hillside, $17,800 \mathrm{ft} S$., $1,825 \mathrm{ft} E$. of $\mathrm{NW}$. cor. quadrangle, Pleyto land grant. Fossils: foraminifers. Age and correlation: Miocene, upper Luisian Stage. Collector: D. L. Durham, 1963. Reference: Durham, 1968a, table 3.

USGS loc. Mf788 (field No. 634104). On hillside, $12,600 \mathrm{ft} \mathrm{S}$., 4,950 ft E. of NW. cor. quadrangle, Pleyto land grant. Fossils: foraminifers. Age and correlation: Miocene, upper Luisian Stage. Collector: D. L. Durham, 1963. Reference: Durham, 1968a, table 3.

USGS loc. Mf825 (field No. 644037). In roadcut, 100 $\mathrm{ft}$ N., 1,525 ft E. of SW. cor. sec. 10, T. $25 \mathrm{~S}$., R. 10 E. Fossils: foraminifers. Age and correlation: Miocene, upper Relizian Stage. Collector: D. L. Durham, 1964. Reference: Durham, 1968a, table 3.

USGS loc. Mf826 (field No. 644074). In roadcut, $1,350 \mathrm{ft} \mathrm{N}$., $1,400 \mathrm{ft}$ E. of SW. cor. sec. 3, T. $25 \mathrm{~S}$., R. 10 E. Fossils: foraminifers. Age and correlation: Miocene upper Relizian or lower Luisian Stage. Collector: D. L. Durham, 1964, Reference: Durham, 1968a, table 3.

USGS loc. Mf827 (field No. 644077). In roadcut, 1,300 ft N., 1,050 ft E. of SW. cor. sec. 3, T. 25 S., R. 10 E. Fossils: foraminifers. Age and correlation: Miocene, Relizian or Lower Luisian Stage. Collector: D. L. Durham, 1964. Reference: Durham, 1968a, table 3.

USGS loc. Mf828 (field No. 644192). In canyon bottom, 1,850 ft N., 1,500 ft W. of SE. cor. sec. 4, T. 25 S., R. 10 E. Fossils: foraminifers. Age and correlation: Miocene, upper Relizian or lower Luisian Stage. Collector: D. L. Durham, 1964. Reference: Durham, 1968a, table 3.

USGS loc. Mf830 (field No. 644242). On hillside, $2,925 \mathrm{ft} \mathrm{N}$., 2,175 ft E. of SW. cor. sec. 32, T. $24 \mathrm{~S}$., R. 10 E. Fossils: foraminifers. Age and correlation: Miocene, lower Luisian Stage. Collector: D. L. Durham, 1964. Reference: Durham, 1968a, table 3. Remarks: fossil locality in figure 39.

USGS loc. Mf831 (field No. 644260). In roadcut, 1,975 $\mathrm{ft} \mathrm{S.,} 250 \mathrm{ft}$ E. of NW. cor. sec. 10, T. 25 S., R. 10 E. Fossils: foraminifers. Age and correlation: Miocene,
Monterey Formation, Sandholdt Member-Continued

Tierra Redonda Mountain quadrangle-Continued lower Luisian Stage. Collector: D. L. Durham, 1964. Reference: Durham, 1968a, table 3.

USGS loc. Mf832 (field No. 644375). On hillside, 3,475 ft N., $50 \mathrm{ft}$ E. of SW. cor. sec. 32, T. 24 S., R. 10 E. Fossils: foraminifers. Age and correlation: Miocene, lower Luisian Stage. Collector: D. L. Durham, 1964. Reference: Durham, 1968a, table 3. Remarks: fossil locality in figure 39.

USGS loc. Mf853 (field No. 654003). On hillside, 1,850 ft S., 1,475 ft W. of NE. cor. sec. 7, T. 25 S., R. 10 E. Fossils: foraminifers. Age and correlation: Miocene, lower Luisian Stage. Collectors: D. L. Durham and T. L. Winder, 1965. Reference: Durham, 1968a, table 3. Remarks: fossil locality in figure 41.

USGS loc. Mf854 (field No. 654019). In roadcut, 1,950 ft S., 2,400 ft E. of NW. cor. sec. 5, T. 25 S., R. 10 E. Fossils: foraminifers. Age and correlation: Miocene, upper Relizian or lower Luisian Stage. Collectors: D. L. Durham and T. L. Winder, 1965. Reference: Durham, 1968a, table 3. Remarks: fossil locality in figure 41.

USGS loc. Mf893 (field No. 644330). In roadcut, 50 $\mathrm{ft}$ N., 1,750 ft W. of SE. cor. sec. 5, T. 25 S., R. 10 E. Fossils: foraminifers. Age and correlation: Miocene, Saucesian Stage. Collector: D. L. Durham, 1964. Reference: Durham, 1968a, table 3. Remarks: fossil locality in figure 41.

USGS loc. Mf899 (field No. 662066). In roadcut, 400 ft S., 1,600 ft E. of NW. cor. sec. 15, T. 25 S., R. 10 E. Fossils: foraminifers. Age and correlation: Miocene, Saucesian Stage. Collector: D. L. Durham, 1966. Reference: Durham, 1968a, table 3.

USGS loc. Mf901 (field No. 662068). Series of samples from sequence of beds $80 \mathrm{ft}$ thick in roadcut, about $600 \mathrm{ft} \mathrm{S.,} 200 \mathrm{ft}$ W. of NE. cor. sec. 9, T. $25 \mathrm{~S}$., R. 10 E. Fossils: foraminifers. Age and correlation: Miocene, upper Relizian or lower Luisian Stage at base, lower Luisian Stage above. Collector: D. L. Durham, 1966. Reference: Durham, 1968a, table 4.

USGS loc. Mf1489 (field No. 694021). In roadcut, $17,500 \mathrm{ft} \mathrm{S}$., $6,100 \mathrm{ft} \mathrm{E}$. of $\mathrm{NW}$. cor. quadrangle, Pleyto land grant. Fossils: foraminifers. Age and correlation: Miocene, Saucesian Stage. Collector: D. L. Durham, 1969.

USGS loc. Mf1491 (field No. 694023). In roadcut, 300 $\mathrm{ft}$ S., 2,700 ft W. of NE. cor. sec. 8, T. 25 S., R. $10 \mathrm{E}$. Fossils: foraminifers. Age and correlation: Miocene, Saucesian Stage. Collector: D. L. Durham, 1969. Remarks: fossil locality in figure 41.

Loc. B-2. In roadcut " 3100 ' due south of lower edge of ' $\mathrm{E}$ ' in Pleyto" (Bradley 15-minute quadrangle), projected sec. 22, T. 9 S., R. 24 E. (M. N. Bramlette, unpub. field notes dated December 1943). Fossils: foraminifers. Collector: M. N. Bramlette, 1943. Reference: Bandy and Ingle, 1970, p. 159.

Bradley quadrangle

USGS loc. Mf820 (field No. 641041). In bank of Nacimiento River, $2,825 \mathrm{ft} \mathrm{S.,} 1,050 \mathrm{ft} \mathrm{W}$. of NE. cor. sec. 14, T. 25 S., R. 10 E. Fossils: foraminifers. Age and correlation: Miocene, upper Luisian Stage. Collectors: D. L. Durham and R. J. McLaughlin, 1964. Reference: Durham, 1968a, table 3. 
Monterey Formation, Sandholdt Member-Continued Bradley quadrangle - Continued

USGS loc. Mf829 (field No. 644213). In bank of Nacimiento River, 2,500 ft S., 1,500 ft E. of NW. cor. sec. 14, T. 25 S., R. 10 E. Fossils: foraminifers. Age and correlation: Miocene, upper Relizian Stage. Collector: D. L. Durham, 1964. Reference. Durham, 1968a, table 3.

Lime Mountain quadrangle

USGS loc. Mf1448 (field No. 692040). In cut on ranch road, $200 \mathrm{ft} \mathrm{S.,} 350 \mathrm{ft}$ E. of NW. cor. sec. 9, T. $26 \mathrm{~S}$., R. 10 E. Fossils: foraminifers. Age: Miocene, lower Relizian Stage. Collector: D. L. Durham, 1969.

USGS loc. Mf1449 (field No. 692041). In streambank, $1,400 \mathrm{ft} \mathrm{N}$., $800 \mathrm{ft} \mathrm{W}$. of SE. cor. sec. $17, T$. $26 \mathrm{~S}$. R. 10 E. Fossils: foraminifers. Age and correlation: Miocene, Saucesian Stage. Collector: D. L. Durham, 1969. Remarks: fauna listed in text.

LSJU loc. 1156. On hillside, $1,100 \mathrm{ft}$ N., $200 \mathrm{ft} \mathrm{W}$. of SE. cor. sec. 7, T. 26 S., R. 10 E. Fossils: foraminifers. Reference: Taliaferro and Schenck, 1933, p. 77.

Loc. M-63. "Small outcrop on bare hillside at head of small canyon about 300 yards above spring in gulch which passes by B.M. 1019," $700 \mathrm{ft} \mathrm{N}$., 2,400 ft E. of SW. cor. sec. 5, T. 26 S., R. 10 E. Fossils: foraminifers. Reference: Schenck and Childs, 1942, p. 26.

Loc. M-64. "Near the head of a small creek just south of a saddle which is east of a hill of 1,000-feet elevation," $1,200 \mathrm{ft} \mathrm{S.,} 2,450 \mathrm{ft}$ W. of NE. cor. sec. 7, T. 26 S., R. 10 E. Fossils: foraminifers. Reference: Schenck and Childs, 1942, p. 26-27.

Adelaida quadrangle

USGS loc. Mf821 (field No. 641056). In canyon bottom $1,300 \mathrm{ft} \mathrm{S.,} 2,375 \mathrm{ft} \mathrm{W}$. of NE. cor. sec. 24 , T. 25 S., R. 10 E. Fossils: foraminifers. Age and correlation: Miocene, upper Luisian Stage. Collectors: D. L. Durham and R. J. McLaughlin, 1964. References: Durham, 1968b; Smith and Durham, 1968, table 1.

USGS loc. Mf822 (field No. 642078). In roadcut, 725 $\mathrm{ft}$ N., 1,075 ft W. of SE. cor. sec. 32, T. $25 \mathrm{~S}$., R. $11 \mathrm{E}$. Fossils: foraminifers. Age and correlation: Miocene, upper Luisian Stage. Collectors: D. L. Durham and R. J. McLaughlin, 1964. References: Durham, 1968b; Smith and Durham, 1968, table 1.

USGS loc. Mf823 (field No. 642079). In roadcut, 1,450 $\mathrm{ft} \mathrm{N}$., $1,600 \mathrm{ft} \mathrm{W}$. of $\mathrm{SE}$. cor. sec. 32, T. $25 \mathrm{~S}$., R. 11 E. Fossils: foraminifers. Age and correlation: Miocene, upper Luisian Stage. Collectors: D. L. Durham and R. J. McLaughlin, 1964. References: Durham, 1968b; Smith and Durham, 1968, table 1.

USGS loc. Mf855 (field No. 654049). In roadcut, 400 ft S., $1,475 \mathrm{ft} \mathrm{W}$. of NE. cor. sec. 16, T. $26 \mathrm{~S}$., R. $11 \mathrm{E}$. Fossils: foraminifers. Age and correlation: Miocene, upper Relizian Stage. Collectors: D. L. Durham and T. L. Winder, 1965. References: Durham, 1968b; Smith and Durham, 1968, table 1.

USGS loc. Mf856 (field No. 654050). In roadcut, 250 $\mathrm{ft} \mathrm{S} ., 1,100 \mathrm{ft} \mathrm{W}$. of NE. cor. sec. 16, T. $26 \mathrm{~S}$., R. $11 \mathrm{E}$. Fossils: foraminifers. Age and correlation: Miocene, Relizian or Luisian Stage. Collectors: D. L. Durham and T. L. Winder, 1965. References: Durham, 1968b; Smith and Durham, 1968, table 1.
Monterey Formation, Sandholdt Member-Continued Adelaida quadrangle-Continued

USGS loc. Mf857 (field No. 654065). On hillside, 2,300 $\mathrm{ft}$ N., $500 \mathrm{ft}$ W. of SE. cor. sec. 10, T. 26 S., R. 11 E. Fossils: foraminifers. Age and correlation: Miocene, lower Luisian Stage. Collector: D. L. Durham, 1965. References: Durham, 1968b; Smith and Durham, 1968 , table 1.

USGS loc. Mf858 (field No. 654119). In roadcut, 1,125 ft S. of NE. cor. sec. 27, T. 26 S., R. 10 E. Fossils: foraminifers. Age and correlation: Miocene, upper Luisian Stage. Collectors: D. L. Durham and T. L. Winder, 1965. References: Durham, 1968b; Smith and Durham, 1968, table 1. Remarks: fauna listed in text.

USGS loc. Mf859 (field No. 654120). In roadcut, 2,200 $\mathrm{ft} \mathrm{S.,} 2,425 \mathrm{ft} \mathrm{W}$. of NE. cor. sec. 26, T. 26 S., R. $10 \mathrm{E}$. Fossils: foraminifers. Age and correlation: Miocene, upper Relizian Stage. Collectors: D. L. Durham and T. L. Winder, 1965. References: Durham, 1968b; Smith and Durham, 1968, table 1.

USGS loc. Mf860 (field No. 654121). In roadcut, 2,575 ft S., $900 \mathrm{ft} \mathrm{E}$. of NW. cor. sec. 25, T. 26 S., R. 10 E. Fossils: foraminifers. Age and correlation: Miocene, lower Relizian Stage. Collectors: D. L. Durham and T. L. Winder, 1965. References: Durham, 1968b; Smith and Durham, 1968, table 1.

USGS loc. Mf861 (field No. 654123). In roadcut, 2,425 $\mathrm{ft} \mathrm{N}$., 1,450 ft E. of SW. cor. sec. 30, T. 26 S., R. 11 E. Fossils: foraminifers. Age and correlation: Miocene, lower Relizian Stage. Collectors: D. L. Durham and T. L. Winder, 1965. References: Durham, 1968b; Smith and Durham, 1968, table 1.

USGS loc. Mf862 (field No. 654136). In roadcut, 850 $\mathrm{ft}$ S., 2,200 ft E. of NW. cor. sec. 22, T. 26 S., R. 11 E. Fossils: foraminifers. Age and correlation: Miocene, lower Relizian Stage. Collectors: D. L. Durham and T. L. Winder, 1965. References: Durham, 1968b; Smith and Durham, 1968, table 1. Remarks: locs. Mf862 and Mf863 are near LSJU loc. 688, collected by H. G. Schenck and listed by Kleinpell (1938, p. 49).

USGS loc. Mf863 (field No. 654137). In roadcut, 225 $\mathrm{ft} \mathrm{S}$, $2,225 \mathrm{ft}$ E. of NW. cor. sec. 22, T. $26 \mathrm{~S}$., R. $11 \mathrm{E}$. Fossils: foraminifers. Age and correlation: Miocene, lower(?) Relizian Stage. Collectors: D. L. Durham and T. L. Winder, 1965. References: Durham, 1968b; Smith and Durham, 1968, table 1.

USGS loc. Mf864 (field No. 654079). On hillside, 1,250 ft N., 2,450 ft E. of SW. cor. sec. 24, T. $25 \mathrm{~S} .$, R. $10 \mathrm{E}$. Fossils: foraminifers. Age and correlation: Miocene, lower Relizian Stage. Collectors: D. L. Durham and T. L. Winder, 1965. References: Durham, 1968b; Smith and Durham, 1968, table 1.

USGS loc. Mf865 (field No. 654192). On hillside, 1,625 ft N., $300 \mathrm{ft}$ E. of SW. cor. sec. 11, T. 26 S., R. $10 \mathrm{E}$. Fossils: foraminifers. Age and correlation: Miocene, Relizian Stage. Collectors: D. L. Durham and T. L. Winder, 1965. References: Durham, 1968b; Smith and Durham, 1968, table 1.

USGS loc. Mf866 (field No. 654200). On hillside, 1,175 ft S., 1,400 ft W. of NE. cor. sec. 23, T. 26 S., R. $10 \mathrm{E}$. Fossils: foraminifers. Age and correlation: Miocene, upper Relizian or lower Luisian Stage. Collectors: 
Monterey Formation, Sandholdt Member-Continued Adelaida quadrangle-Continued

D. L. Durham and T. L. Winder, 1965. References: Durham, 1968b; Smith and Durham, 1968, table 1.

USGS loc. Mf867 (field No. 654214). On hillside, 2,550 ft S., $1,025 \mathrm{ft} \mathrm{E}$. of NW. cor. sec. 24, T. $26 \mathrm{~S}$., R. $10 \mathrm{E}$. Fossils: foraminifers. Age and correlation: Miocene, Relizian or Luisian Stage. Collectors: D. L. Durham and T. L. Winder, 1965. References: Durham, 1968b; Smith and Durham, 1968, table 1.

USGS loc. Mf868 (field No. 654223). In cut along oil pipeline, $225 \mathrm{ft} \mathrm{N}$., $50 \mathrm{ft} \mathrm{E}$. of $\mathrm{SW}$. cor. sec. 24 , T. 26 S., R. 10 E. Fossils: foraminifers. Age and correlation: Miocene, upper Relizian Stage. Collectors: D. L. Durham and T. L. Winder, 1965. References: Durham, 1968b; Smith and Durham, 1968 , table 1.

USGS loc. Mf869 (field No. 654232). On hillside, 275 ft N., 2,250 ft E. of SW. cor. sec. 19, T. 26 S., R. 11 E. Fossils: foraminifers. Age and correlation: Miocene, lower Relizian Stage. Collectors: D. L. Durham and T. L. Winder, 1965. References: Durham, 1968b; Smith and Durham, 1968, table 1.

USGS loc. Mf870 (field No. 654246). On ridgetop, 500 ft S., 1,400 ft E. of NW. cor. sec. 29 , T. 26 S., R. 11 E. Fossils: foraminifers. Age and correlation: Miocene, Relizian Stage. Collectors: D. L. Durham and T. L. Winder, 1965. References: Durham, 1968b; Smith and Durham, 1968, table 1.

USGS loc. Mf871 (field No. 654254). On ridge crest, $1,750 \mathrm{ft} \mathrm{S.,} \mathrm{2,250} \mathrm{ft} \mathrm{E.} \mathrm{of} \mathrm{NW.} \mathrm{cor.} \mathrm{sec.} \mathrm{32,} \mathrm{T.} 26 \mathrm{~S}$., R. 11 E. Fossils: foraminifers. Age and correlation: Miocene, Relizian or lower Luisian Stage. Collectors: D. L. Durham and T. L. Winder, 1965. References: Durham, 1968b; Smith and Durham, 1968, table 1.

USGS loc. Mf872 (field No. 654264). In roadcut, 750 $\mathrm{ft}$ N., $350 \mathrm{ft} \mathrm{W}$. of SE. cor. sec. 26, T. $26 \mathrm{~S}$., R. $10 \mathrm{E}$. Fossils: foraminifers. Age and correlation: Miocene, lower Luisian Stage. Collectors: D. L. Durham and T. L. Winder, 1965. References: Durham, 1968b; Smith and Durham, 1968, table 1.

USGS loc. Mf895 (field No. 662057). In roadcut, 2,450 ft S., 1,450 ft W. of NE. cor. sec. 33, T. 26 S., R. $11 \mathrm{E}$. Fossils: foraminifers. Age and correlation: Miocene, lower Luisian Stage. Collector: D. L. Durham, 1966. References: Durham, 1968b; Smith and Durham, 1968, table 1.

USGS loc. Mf896 (field No. 662060). On hillside, 1,950 ft S., 2,700 ft W. of NE. cor. sec. 33, T. $26 \mathrm{~S} .$, R. 11 E. Fossils: foraminifers. Age and correlation: Miocene, Relizian or Luisian Stage. Collector: D. L. Durham, 1966. References: Durham, 1968b; Smith and Durham, 1968, table 1.

USGS loc. Mf897 (field No. 662064). In roadcut, 2,100 ft S., $400 \mathrm{ft}$ W. of NE. cor. sec. 34, T. 26 S., R. 11 E. Fossils: foraminifers. Age and correlation: Miocene, lower Luisian Stage. Collector: D. L. Durham, 1966. References: Durham, 1968b; Smith and Durham, 1968, table 1.

USGS loc. Mf898 (field No. 662065). In roadcut, 1,550 ft S., 3,000 ft E. of NW. cor. sec. 35, T. 26 S., R. 11 E. Fossils: foraminifers. Age and correlation: Miocene. lower Luisian Stage. Collector: D. L. Durham, 1966.
Monterey Formation, Sandholdt Member-Continued Adelaida quadrangle - Continued

References: Durham, 1968b; Smith and Durham, 1968, table 1.

LSJU loc. 689. "On Las Tablas Creek, where it crosses the E. line of Section 26," T. 26 S., R. 10 E. Fossils: foraminifers. Reference: Kleinpell, 1938, p. 49.

York Mountain quadrangle

USGS loc. Mf1440 (field No. 692032). In roadcut, 200 $\mathrm{ft}$ S., $450 \mathrm{ft}$ W. of NE. cor. sec. 12, T. 27 S., R. $10 \mathrm{E}$. Fossils: foraminifers. Age and correlation: Miocene, upper Saucesian or lower Relizian Stage. Collector: D. L. Durham, 1969.

USGS loc. Mf1441 (field No. 692033). In roadcut, $13,600 \mathrm{ft} \mathrm{S}$., $20,300 \mathrm{ft} \mathrm{W}$. of NE. cor. quadrangle, Paso de Robles land grant. Fossils: foraminifers. Age and correlation: Miocene, lower Relizian Stage. Collector: D. L. Durham, 1969. Remarks: fauna listed in text.

USGS loc. Mf1442 (field No. 692034). In ditch along road, $21,600 \mathrm{ft} \mathrm{S}$., $10,750 \mathrm{ft} \mathrm{W}$. of $\mathrm{NE}$. cor. quadrangle, Paso de Robles land grant. Fossils: foraminifers. Age and correlation: Miocene, Saucesian Stage. Collector: D. L. Durham, 1969. Remarks: fauna listed in text.

USGS loc. Mf1443 (field No. 692035). In roadcut, $19,350 \mathrm{ft} \mathrm{N}$., $10,000 \mathrm{ft} \mathrm{W}$. of $\mathrm{SE}$. cor. quadrangle, Paso de Robles land grant. Fossils: foraminifers. Age and correlation: Miocene, upper Saucesian or lower Relizian Stage. Collector: D. L. Durham, 1969.

USGS loc. Mf1444 (field No. 692036). In roadcut, $17,000 \mathrm{ft} \mathrm{N}$., $12,875 \mathrm{ft}$ W. of $S E$. cor. quadrangle, Paso de Robles land grant. Fossils: foraminifers. Age and correlation: Miocene, upper Saucesian or lower Relizian Stage. Collector: D. L. Durham, 1969.

USGS loc. Mf1445 (field No. 692037). In roadcut, $21,300 \mathrm{ft} \mathrm{N}$., $3,250 \mathrm{ft} \mathrm{W}$. of SE. cor. quadrangle, Paso de Robles land grant. Fossils: foraminifers. Age and correlation: Miocene, upper Saucesian or lower Relizian Stage. Collector: D. L. Durham, 1969.

USGS loc. Mf1447 (field No. 692039). In roadcut $12,100 \mathrm{ft} \mathrm{N}$., $50 \mathrm{ft} \mathrm{W}$. of SE. cor. quadrangle, Paso de Robles land grant. Fossils: foraminifers. Age and correlation: Miocene, lower Relizian Stage. Collector: D. L. Durham, 1969.

USGS loc. Mf1450 (field No. 692043). In roadcut, $19,400 \mathrm{ft} \mathrm{S}$., $350 \mathrm{ft} \mathrm{W}$. of NE. cor. quadrangle, Paso de Robles land grant. Fossils: foraminifers. Age and correlation: Miocene, upper Relizian or lower Luisian Stage. Collector: D. L. Durham, 1969.

USGS loc. Mf1452 (field No. 692045). On ridge crest, $8,000 \mathrm{ft} \mathrm{N}$., $50 \mathrm{ft} \mathrm{W}$. of SE. cor. quadrangle, Paso de Robles land grant. Fossils: foraminifers. Age and correlation: Miocene, Relizian Stage. Collector: D. L. Durham, 1969.

USGS loc. Mf1458 (field No. 692051). In roadcut, $15,900 \mathrm{ft} \mathrm{S}$., $10,025 \mathrm{ft} \mathrm{W}$. of NE. cor. quadrangle, Paso de Robles land grant. Fossils: foraminifers. Age and correlation: Miocene, Relizian or lower Luisian Stage. Collector: D. L. Durham, 1969.

USGS loc. Mf1459 (field No. 692052). In roadcut, $1,600 \mathrm{ft} \mathrm{N}$., $2,325 \mathrm{ft} \mathrm{W.} \mathrm{of} \mathrm{SE.} \mathrm{cor.} \mathrm{sec.} \mathrm{5,} \mathrm{T.} 27 \mathrm{~S}$., R. 11 E. Fossils: foraminifers. Age and correlation: Miocene, lower Relizian Stage. Collector: D. L. Durham, 1969. 
Monterey Formation, Sandholdt Member-Continued York Mountain quadrangle - Continued

LSJU loc. 679. "On east side of ridge, about 15 feet below crest," ctr. sec. 12, T. 27 S., R. 10 E. Fossils: foraminifers. Collector: R. R. Wilson. Reference: Kleinpell, 1938, p. 49.

LSJU loc. 681. On Summit Creek, "2,100 feet N., 75 E. of German Church," Paso de Robles land grant. Fossils: foraminifers. Reference: Kleinpell, 1938, p. 49.

Loc. A-23. Along road about $950 \mathrm{ft} S ., 1,350 \mathrm{ft} E$. of NW. cor. sec. 4, T. 27 S., R. 11 E., "at 1.6 miles N. of Summit School" (M. N. Bramlette, unpub. field notes dated May 30, 1944). Fossils: foraminifers. Collector: M. N. Bramlette, 1944. Reference: Bandy and Ingle, 1970, p. 159.

Templeton quadrangle

USGS loc. Mf1011 (field No. 674022). In roadcut, $16,950 \mathrm{ft} \mathrm{N}$., $15,300 \mathrm{ft} \mathrm{E}$. of $\mathrm{SW}$. cor. quadrangle, Asuncion land grant. Fossils: foraminifers. Age and correlation: Miocene, Relizian or lower Luisian Stage. Collector: D. L. Durham, 1967.

USGS loc. Mf1446 (field No. 692038). In roadcut, $18,900 \mathrm{ft} \mathrm{N}$., $350 \mathrm{ft}$ E. of SW. cor. quadrangle, Paso de Robles land grant. Fossils: foraminifers. Age and correlation: Miocene, Saucesian Stage. Collector: D. L. Durham, 1969. Remarks: fauna listed in text.

USGS loc. Mf1457 (field No. 692050). In roadcut, $1,750 \mathrm{ft}$ N., $11,675 \mathrm{ft} \mathrm{E}$. of $\mathrm{SW}$. cor. quadrangle, Asuncion land grant. Fossils: foraminifers. Age and correlation: Miocene, upper(?) Saucesian Stage. Collector: D. L. Durham, 1969.

Atascadero quadrangle

USGS loc. Mf1451 (field No. 692044). In roadcut, $23,600 \mathrm{ft} \mathrm{S}, 8,600 \mathrm{ft} \mathrm{W}$. of $\mathrm{NE}$. cor. quadrangle, Asuncion land grant. Fossils: foraminifers. Age and correlation: Miocene, upper Saucesian or lower Relizian Stage. Collector: D. L. Durham, 1969. Remarks: about $900 \mathrm{ft} \mathrm{S}$. of S. border of mapped area.

USGS loc. Mf1453 (field No. 692046). In bank of Graves Creek, $1,375 \mathrm{ft} \mathrm{S}$., $16,400 \mathrm{ft} \mathrm{E}$. of NW. cor. quadrangle, Asuncion land grant. Fossils: foraminifers. Age and correlation: Miocene, Relizian Stage. Collector: D. L. Durham, 1969.

USGS loc. Mf1455 (field No. 692048). In bank of Graves Creek, 2,100 ft S., $16,150 \mathrm{ft} \mathrm{E}$. of $\mathrm{NW}$. cor. quadrangle, Asuncion land grant. Fossils: foraminifers. Age and correlation: Miocene, lower Relizian Stage. Collector: D. L. Durham, 1969. Remarks: fauna listed in text.

USGS loc. Mf1501 (field No. 168). Near road, 5,100 ft S., $19,800 \mathrm{ft} \mathrm{W}$. of $\mathrm{NE}$. cor. quadrangle, Asuncion land grant. Fossils: foraminifers. Age and correlation: Miocene, middle or upper Saucesian Stage. Collector: E. W. Hart, 1968.

Santa Margarita quadrangle

USGS loc. Mf1190 (field No. 682054). In streambank, $150 \mathrm{ft} \mathrm{S.,} \mathrm{1,375} \mathrm{ft} \mathrm{W.} \mathrm{of} \mathrm{NE.} \mathrm{cor.} \mathrm{sec.} \mathrm{19,} \mathrm{T.} 28 \mathrm{~S}$., R. 13 E. Fossils: foraminifers. Age and correlation: Miocene, upper Saucesian or lower Relizian Stage. Collector: D. L. Durham, 1968.

USGS loc. Mf1191 (field No. 682058). In roadcut, $1,950 \mathrm{ft}$ S., $700 \mathrm{ft} \mathrm{W}$. of NE. cor. sec. 31 , T. $28 \mathrm{~S}$.,
Monterey Formation, Sandholdt Member-Continued

Santa Margarita quadrangle-Continued

R. 13 E. Fossils: foraminifers. Age and correlation: Miocene, lower Relizian Stage. Collector: D. L. Durham, 1968. Remarks: fauna listed in text.

USGS loc. Mf1192 (field No. 682060). In cut by earthfill dam, $1,950 \mathrm{ft} S$., $1,400 \mathrm{ft} E$. of NW. cor. sec. 32 , T. 28 S., R. 13 E. Fossils: foraminifers. Age and correlation: Miocene, lower Relizian Stage. Collector: D. L. Durham, 1968.

Wilson Corner quadrangle

USGS loc. Mf1176 (field No. 682019). In creek bank, $2,075 \mathrm{ft}$ S., $1,400 \mathrm{ft} \mathrm{W}$. of NE. cor. sec. $24, T$. $28 \mathrm{~S}$., R. 14 E. Fossils: foraminifers. Age and correlation: Miocene, Relizian or Luisian Stage. Collector: D. L. Durham, 1968.

USGS loc. Mf1177 (field No. 682020). In creek bank, $2,850 \mathrm{ft} \mathrm{S}$., $825 \mathrm{ft} \mathrm{W}$. of NE. cor. sec. $24, \mathrm{~T}$. $28 \mathrm{~S}$., R. 14 E. Fossils: foraminifers. Age and correlation: Miocene, upper(?) Luisian Stage. Collector: D. L. Durham, 1968.

USGS loc. Mf1178 (field No. 682021). In bluff, 1,150 ft N., $200 \mathrm{ft} \mathrm{W.} \mathrm{of} \mathrm{SE.} \mathrm{cor.} \mathrm{sec.} \mathrm{24,} \mathrm{T.} 28$ S., R. 14 E. Fossils: foraminifers. Age and correlation: Miocene, Luisian(?) Stage. Collector: D. L. Durham, 1968.

USGS loc. Mf1179 (field No. 682022). In creek bank, $375 \mathrm{ft} \mathrm{N}$., $375 \mathrm{ft}$ W. of SE. cor. sec. 24 , T. $28 \mathrm{~S}$., R. 14 E. Fossils: foraminifers. Age and correlation: Miocene, lower Luisian Stage. Collector: D. L. Durham, 1968.

USGS loc. Mf1180 (field No. 682030). In artificial cut near Indian Creek, $100 \mathrm{ft} \mathrm{S.,} \mathrm{3,000} \mathrm{ft} \mathrm{E.} \mathrm{of} \mathrm{NW.} \mathrm{cor.}$ sec. 29, T. 28 S., R. 15 E. Fossils: foraminifers. Age: Miocene. Collector: D. L. Durham, 1968.

USGS loc. Mf1181 (field No. 682031). In roadcut, $1,825 \mathrm{ft} \mathrm{S}$., 2,350 ft E. of NW. cor. sec. 29 , T. $28 \mathrm{~S}$., R. 15 E. Fossils: foraminifers. Age and correlation: Miocene, Luisian Stage. Collector: D. L. Durham, 1968.

USGS loc. Mf1182 (field No. 682034). In roadcut, $2,300 \mathrm{ft} \mathrm{S}$., 2,150 ft E. of NW. cor. sec. 29 , T. $28 \mathrm{~S}$., R. 15 E. Fossils: foraminifers. Age and correlation: Miocene, Relizian or lower Luisian Stage. Collector: D. L. Durham, 1968.

USGS loc. Mf1183 (field No. 682035). In bluff along Indian Creek, $400 \mathrm{ft} \mathrm{S.,} \mathrm{2,575} \mathrm{ft} \mathrm{E.} \mathrm{of} \mathrm{NW.} \mathrm{cor.} \mathrm{sec.}$ 29, T. 28 S., R. 15 E. Fossils: foraminifers. Age and correlation: Miocene, Luisian Stage. Collector: D. L. Durham, 1968.

USGS loc. Mf1184 (field No. 682037). In roadcut, $1,025 \mathrm{ft} \mathrm{S}$., $600 \mathrm{ft} \mathrm{E}$. of NW. cor. sec. 24, T. $28 \mathrm{~S}$., R. 14 E. Fossils: foraminifers. Age and correlation: Miocene, Luisian or Mohnian Stage. Collector: D. L. Durham, 1968.

USGS loc. Mf1185 (field No. 682039). On side of canyon, $1,050 \mathrm{ft} \mathrm{N}$., $475 \mathrm{ft} \mathrm{W}$. of $\mathrm{SE}$. cor. sec. 21 , T. 28 S., R. 14 E. Fossils: foraminifers. Age and correlation: Miocene, lower Luisian Stage. Collector: D. L. Durham, 1968.

USGS loc. Mf1186 (field No. 682040). In gully, $500 \mathrm{ft}$ N., $800 \mathrm{ft} \mathrm{W}$. of SE. cor. sec. 21, T. $28 \mathrm{~S}$., R. $14 \mathrm{E}$. Fossils: foraminifers. Age and correlation: Miocene, upper(?) Relizian Stage. Collector: D. L. Durham, 1968. 
Monterey Formation, Sandholdt Member-Continued

Wilson Corner quadrangle-Continued

USGS loc. Mf1187 (field No. 682040A). At top of bluff about $45 \mathrm{ft}$ stratigraphically above locality Mf1186, $675 \mathrm{ft} \mathrm{N}$., $750 \mathrm{ft} \mathrm{W}$. of SE. cor. sec. 21 , T. $28 \mathrm{~S}$., R. 14 E. Fossils: foraminifers. Age and correlation: Miocene, Luisian Stage. Collector: D. L. Durham, 1968.

USGS loc. Mf1188 (field No. 682041). Near ridge crest, $1,350 \mathrm{ft} \mathrm{S}$., $150 \mathrm{ft} \mathrm{E}$. of NW. cor. sec. 27, T. 28 S., R. 14 E. Fossils foraminifers. Age and correlation: Miocene, lower Relizian Stage. Collector: D. L. Durham, 1968.

USGS loc. Mf1189 (field No. 682050). In creek bank, $1,900 \mathrm{ft} \mathrm{S}$., $1,550 \mathrm{ft} \mathrm{W}$. of NE. cor. sec. 16, T. $28 \mathrm{~S}$., R. 14 E. Fossils: foraminifers. Age and correlation: Miocene, lower Luisian Stage. Collector: D. L. Durham, 1968. Remarks: fauna listed in text.

Monterey Formation, Hames Member

Reliz Canyon quadrangle

UC loc. 6009. On ridge, about $1,450 \mathrm{ft} \mathrm{S.,} 2,450 \mathrm{ft} \mathrm{W}$. of NE. cor. sec. 33, T. 19 S., R. 6 E. Fossils: mollusks. Collector: H. W. Lee, 1922. Reference: Lee, 1923.

San Ardo quadrangle

USGS loc. M4198 (field No. ACSA 69-3). On ridge crest, about $1,200 \mathrm{ft} S$., $1,150 \mathrm{ft} E$. of $N W$. cor. sec. 19, T. 22 S., R. 10 E. Fossils: mollusks. Age: late Miocene. Collectors: W. O. Addicott, Kôichirô Masuda, T. W. Dibblee, Jr., and D. L. Durham, 1970.

Stockdale Mountain quadrangle

USGS loc. M3990 (field No. 684005). On hillside, 2,025 ft S., $1,475 \mathrm{ft} \mathrm{W}$. of NE. cor. sec. 7, T. 23 S., R. 13 E. Fossils: mollusks. Age: middle or late Miocene. Collector: D. L. Durham, 1968.

USGS loc. M4005 (field No. 684034). In creek bottom, $1,350 \mathrm{ft} \mathrm{S}$., $50 \mathrm{ft} \mathrm{E}$. of NW. cor. sec. 6, T. $23 \mathrm{~S}$., R. 13 E. Fossils: mollusks. Age: Miocene or early Pliocene. Collector: D. L. Durham, 1968.

Santa Margarita Formation

Stockdale Mountain quadrangle

USGS loc. M1968 (field No. 641003). On hillside, 2,700 $\mathrm{ft} \mathrm{N}$., 1,775 ft E. of SW. cor. sec. 34, T. $23 \mathrm{~S}$., R. $13 \mathrm{E}$. Fossils: mollusks, barnacles. Age: late Miocene. Collectors: W. O. Addicott and D. L. Durham, 1964. Reference: Durham and Addicott, 1965, p. A11.

USGS loc. M1969 (field No. 641003-PR). On hillside, $2,625 \mathrm{ft} \mathrm{N}$., 1,850 ft E. of SW. cor. sec. 34, T. $23 \mathrm{~S}$., R. 13 E. Fossils: brachiopods, mollusks. Age: late Miocene. Collectors: W. O. Addicott and D. L. Durham, 1965. Reference Durham and Addicott, 1965, table 1. Remarks: about $12 \mathrm{ft}$ stratigraphically above loc. M1968; age determination revised from early Pliocene to late Miocene; fauna listed in text.

USGS loc. M3950 (field No. 786-514a). On steep slope, $300 \mathrm{ft} \mathrm{N}$., $325 \mathrm{ft}$ E. of SW. cor. sec. 23 , T. 23 S., R. 13 E., and (along strike of beds) $150 \mathrm{ft} \mathrm{S.,}$ $850 \mathrm{ft}$ E. of NW. cor. sec. 26, T. 23 S., R. $13 \mathrm{E}$. Fossils: mollusks. Age: late Miocene. Collector: O. F. Huffman, 1968.

USGS loc. M3952 (field No. 786-520d). On hillside, $2,200 \mathrm{ft} \mathrm{S.,} 800 \mathrm{ft} \mathrm{W}$. of NE. cor. sec. 17, T. $23 \mathrm{~S}$., R. 13 E. Fossils: mollusks. Age: late Miocene. Collector: O. F. Huffman, 1968.
Santa Margarita Formation-Continued

Stockdale Mountain quadrangle--Continued

USGS loc. M3954 (field No. 786-521 b b $_{2}$. On hillside, $500 \mathrm{ft} \mathrm{S}$., $2,050 \mathrm{ft} \mathrm{W}$. of NE. cor. sec. 17, T. $23 \mathrm{~S}$., R. 13 E. Fossils: mollusks, barnacles. Age: late Miocene. Collector: O. F. Huffman, 1968. Remarks: fauna listed in text.

USGS loc. M3989 (field No. 684004). On ridgetop, 50 ft N., 2,100 ft E. of SW. cor. sec. 8, T. 23 S., R. $13 \mathrm{E}$. Fossils: mollusks. Age: late Miocene. Collector: D. L. Durham, 1968.

USGS loc. M3992 (field No. 684007). On hillside, $1,150 \mathrm{ft} \mathrm{N}$., 2,550 ft W. of SE. cor. sec. 8, T. $23 \mathrm{~S}$., R. 13 E. Fossils mollusks. Age: late Miocene. Collector: D. L. Durham, 1968.

USGS loc. M3993 (field No. 684013). On hillside, 450 $\mathrm{ft} \mathrm{N}$., $500 \mathrm{ft}$ E. of SW. cor. sec. 22, T. 23 S., R. $13 \mathrm{E}$. Fossils: mollusks. Age: late Miocene. Collector: D. L. Durham, 1968.

USGS loc. M3994 (field No. 684014). On ridge crest, $1,100 \mathrm{ft} \mathrm{S}$., $2,000 \mathrm{ft} \mathrm{E}$. of NW. cor. sec. 26, T. $23 \mathrm{~S}$., R. 13 E. Fossils mollusks. Age: probably late Miocene. Collector: D. L. Durham, 1968.

USGS loc. M3995 (field No. 684018). On hillside, 200 $\mathrm{ft}$ N., 2,550 ft E. of SW. cor. sec. 16, T. 23 S., R. 13 E. Fossils: mollusks. Age: late Miocene. Collector: D. L. Durham, 1968.

USGS loc. M3996 (field No. 684020). In streambank, $2,500 \mathrm{ft} \mathrm{N}$., 1,100 ft E. of SW. cor. sec. 28 , T. $23 \mathrm{~S}$., R. 13 E. Fossils: mollusks. Age: late Miocene or early Pliocene. Collectors: D. L. Durham, 1968; W. O. Addicott and D. L. Durham, 1969.

USGS loc. M4001 (field No. 684028). In roadcut, $1,550 \mathrm{ft} \mathrm{S}$., $50 \mathrm{ft} E$. of NW. cor. sec. $20, T .23 \mathrm{~S}$., R. 13 E. Fossils: mollusks. Age: late Miocene. Collector: D. L. Durham, 1968.

USGS loc. M4002 (field No. 684030). On side of canyon, $1,050 \mathrm{ft} \mathrm{N}$., $650 \mathrm{ft} E$. of $S W$. cor. sec. 35, T. 23 S., R. 13 E. Fossils: mollusks, barnacle fragments. Age: late Miocene. Collector: D. L. Durham, 1968.

USGS loc. M4003 (field No. 684031). In creek bank, $1,000 \mathrm{ft} \mathrm{S.,} \mathrm{2,075} \mathrm{ft} \mathrm{E.} \mathrm{of} \mathrm{NW.} \mathrm{cor.} \mathrm{sec.} \mathrm{35,} \mathrm{T.} 23 \mathrm{~S}$., R. 13 E. Fossils: mollusks. Age: late Miocene. Collector: D. L. Durham, 1968.

USGS loc. M4004 (field No. 684033). On canyon side, $2,150 \mathrm{ft} \mathrm{N}$., 2,900 ft W. of SE. cor. sec. 31, T. $22 \mathrm{~S}$., R. 13 E. Fossils: mollusks. Age: probably late Miocene. Collector: D. L. Durham, 1968.

USGS loc. M4008 (field No. 684044). On hillside, $2,250 \mathrm{ft} \mathrm{N}$., 2,575 ft E. of SW. cor. sec. 34, T. $23 \mathrm{~S}$., R. 13 E. Fossils: mollusks. Age: late Miocene. Collector: T. W. Dibblee, Jr., 1968. Remarks: fauna listed in text.

USGS loc. M4069 (field No. 692026). Pieces of rock in plowed field, about $1,200 \mathrm{ft} \mathrm{S}$., $150 \mathrm{ft} \mathrm{W}$. of NE. cor. sec. 29 , T. 23 S., R. 13 E. Fossils: mollusks. Age: late Miocene or early Pliocene. Collectors: W. O. Addicott and D. L. Durham, 1969.

USGS loc. M4070 (field No. 692027). On hillside, $2,500 \mathrm{ft} \mathrm{N}$., 2,325 ft E. of SW. cor. sec. 34, T. $23 \mathrm{~S}$., R. 13 E. Fossils: mollusks. Age: late Miocene or early Pliocene. Collectors: W. O. Addicott and D. L. Durham, 1969. 
Santa Margarita Formation-Continued

Stockdale Mountain quadrangle - Continued

USGS loc. M4071 (field No. 692028). On hillside, collected along strike of beds, about $50 \mathrm{ft} N ., 1,125 \mathrm{ft} \mathrm{E}$. of SW. cor. sec. 5, T. 23 S., R. 13 E. Fossils: echinoids, mollusks. Age: late Miocene or early Pliocene. Collectors: W. O. Addicott and D. L. Durham, 1969.

USGS loc. M4072 (field No. 692029). On hillside, $1,250 \mathrm{ft} \mathrm{N}$., $2,400 \mathrm{ft} \mathrm{W}$. of SE. cor. sec. $8, T$. $23 \mathrm{~S}$., R. 13 E. Fossils: brachiopods, mollusks. Age: late Miocene. Collectors: W. O. Addicott and D. L. Durham, 1969. Remarks: fauna listed in text.

USGS loc. M4073 (field No. 692030). On hillside, $2,275 \mathrm{ft} \mathrm{N}$., $1,900 \mathrm{ft} \mathrm{W}$. of SE. cor. sec. 8, T. $23 \mathrm{~S}$., R. 13 E. Fossils: echinoids, mollusks. Age: late Miocene or early Pliocene. Collectors: W. O. Addicott and D. L. Durham, 1969.

USGS loc. M4086. On ridge, 1,250 ft $S$., 1,900 ft E. of NW. cor. sec. 26, T. 23 S., R. 13 E. Fossils: mollusks. Age: late Miocene or early Pliocene. Collector: W. O. Addicott, 1969. Remarks: about $50 \mathrm{ft}$ stratigraphically below loc. M3994.

Loc. 2259. Along Middle Fork, $2,080 \mathrm{ft} \mathrm{S.,} 1,520 \mathrm{ft}$ E. of NW. cor. sec. 28 , T. 23 S., R. 13 E. Fossils: foraminifers. Reference: Taggart and Kraetsch, 1963.

Loc. SM-1. East side of Middle Fork, 1,900 ft N., $1,000 \mathrm{ft} \mathrm{W}$. of SE. cor. sec. 32 , T. $23 \mathrm{~S}$., R. $13 \mathrm{E}$. Fossils: brachiopods, mollusks, barnacles. Collector: M. N. Bramlette, 1943. Reference: M. N. Bramlette, unpub. field notes dated Nov. 11, 1943.

Tierra Redonda Mountain quadrangle

USGS loc. M1936 (field No. 634002). On hillside, $21,600 \mathrm{ft} \mathrm{N}$., $11,650 \mathrm{ft}$ W. of SE. cor. quadrangle, Pleyto land grant. Fossils echinoid spines, mollusks. Age: late Miocene. Collectors: W. O. Addicott and D. L. Durham, 1963. Reference: Durham, 1968a, table 5. Remarks: fossil locality in figure 39.

USGS loc. M1940. On hillside, 2,500 ft S., 2,175 ft W. of NE. cor. sec. 33, T. 24 S., R. 10 E. Fossils: echinoids, mollusks. Age: late Miocene. Collectors: W. O. Addicott and D. L. Durham, 1963. Reference: Durham, 1968a, table 5.

USGS loc. M2308 (field No. 644373). On steep hillside, $19,950 \mathrm{ft}$ N., $12,250 \mathrm{ft} \mathrm{W}$. of $\mathrm{SE}$. cor. quadrangle, Pley to land grant. Fossils: echinoids, mollusks. Age: late Miocene. Collector: D. L. Durham, 1964. Reference: Durham, 1968a, table 5. Remarks: fossil locality in figure 39.

Bradley quadrangle

USGS loc. M2046 (field No. 641012). On hillside, $1,800 \mathrm{ft} \mathrm{N}$., $100 \mathrm{ft}$ W. of SE. cor. sec. 11, T. $25 \mathrm{~S}$., R. 10 E. Fossils: brachiopods, mollusks. Age: late Miocene. Collectors: W. O. Addicott, D. L. Durham, and R. J. McLaughlin, 1964. Reference: Durham, 1965b, p. D110; Durham, 1968a, table 5.

UCLA loc. 1106. "Three miles southwesterly on south side and up the Nacimiento River from the Nacimiento Ranch house, well toward the head of a ravine northwest of 1,108 -foot hill, in the $\mathrm{NW} 1 / 4$ of the SE $1 / 4$ of sec. 13, T. 25 S., R. 10 E." Fossils: brachiopods. Collectors: Mr. and Mrs. E. H. Quayle, 1938. Reference: Hertlein and Grant, 1944, p. 123.
Santa Margarita Formation-Continued

Adelaida quadrangle

USGS loc. M2048 (field No. 642146-A). In cut along oil pipeline, $2,250 \mathrm{ft} \mathrm{S}$., $875 \mathrm{ft}$ E. of $\mathrm{NW}$. cor. sec. 19 , T. 25 S., R. 11 E. Fossils: mollusks. Age: probably late Miocene. Collectors: W. O. Addicott, D. L. Durham, and R. J. McLaughlin, 1964. Reference: Durham, 1968b.

USGS loc. M2049 (field No. 642146-B). In cut along oil pipeline, 2,300 ft S., $500 \mathrm{ft}$ E. of NW. cor. sec. 19, T. 25 S., R. 11 E. Fossils: echinoids, brachiopods, mollusks, barnacles. Age: late Miocene. Collectors: W. O. Addicott, D. L. Durham, and R. J. McLaughlin, 1964. Reference: Durham, 1965b, p. D110; Durham, 1968b.

USGS loc. M2051 (field No. 642067). In canyon bottom, $1,725 \mathrm{ft} \mathrm{S.,} 150 \mathrm{ft} \mathrm{W}$. of NE. cor. sec. 32 , T. 25 S., R. 11 E. Fossils: echinoids, mollusks. Age: late Miocene. Collectors: W. O. Addicott, D. L. Durham, and R. J. McLaughlin, 1964. Reference Durham, $1968 \mathrm{~b}$.

Loc. 1939A. At SE. cor. NE $1 / 4 \mathrm{NE}^{1 / 4}$ sec. 30, T. $25 \mathrm{~S}$, R. 11 E. Fossils: echinoids, mollusks. Reference: N. L. Taliaferro, unpub. field notes dated May 19, 1939.

Templeton quadrangle

USGS loc. M4193 (field No. 694012). On hillside, $10,100 \mathrm{ft} \mathrm{N}$., 6,150 ft $\mathrm{W}$. of $\mathrm{SE}$. cor. quadrangle, Asuncion land grant. Fossils: mollusks. Age: late Miocene or early Pliocene. Collectors: D. L. Durham and R. J. McLaughlin, 1969.

Wilson Corner quadrangle

USGS loc. M3811 (field No. 682025). At base of hill, $2,500 \mathrm{ft} \mathrm{N}$., 2,225 ft W. of SE. cor. sec. $13, \mathrm{~T} .28 \mathrm{~S}$., R. 14 E. Fossils: mollusks, Age: middle or late Miocene. Collector: D. L. Durham, 1968.

USGS loc. M3812 (field No. 682026). At base of hill, $400 \mathrm{ft} \mathrm{S}$., 1,300 ft W. of NE. cor. sec. 13, T. $28 \mathrm{~S}$., R. 14 E. Fossils: mollusks. Age: late Miocene. Collector: D. L. Durham, 1968.

Pancho Rico Formation

Sycamore Flat quadrangle

UC loc. 6016. Near ctr. S. line sec. 24, T. 19 S., R. 5 E. Fossils: mollusks. Collector: H. W. Lee, 1922. Reference: Lee, 1923, p. 6-7, 15.

Loc. 6. About $400 \mathrm{ft} \mathrm{S.,} \mathrm{2,100} \mathrm{ft} \mathrm{E.} \mathrm{of} \mathrm{NW.} \mathrm{cor.} \mathrm{sec.} 25$, T. 19 S., R. 5 E. Fossils: echinoids, mollusks. Collector: L. F. Schombel, 1938-1939. Reference: Schombel, 1940, p. 27.

Paraiso Springs quadrangle

USGS loc. M2900 (field No. 664074). On ridge, $300 \mathrm{ft}$ N., $1,900 \mathrm{ft} \mathrm{W}$. of SE. cor. sec. 5, T. 19 S., R. 6 E. Fossils: mollusks, barnacles. Age: late Miocene or early Pliocene. Collector: D. L. Durham, 1966. Reference: Durham, 1970, table 3.

USGS loc. M2903 (field No. 1-B). In bluff S. of Arroyo Seco, $500 \mathrm{ft} \mathrm{S.,} \mathrm{1,150} \mathrm{ft} \mathrm{W.} \mathrm{of} \mathrm{NE.} \mathrm{cor.} \mathrm{sec.}$ 25, T. 19 S., R. 5 E. Fossils: mollusks. Age: late Miocene or Pliocene. Collector: R. L. Bendixen, 1966. Reference: Durham, 1970, table 3.

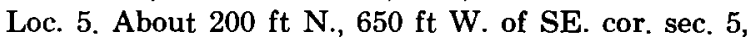
T. 19 S., R. 6 E. Fossils: mollusks. Collector: L. F. Schombel, 1938-39. Reference: Schombel, 1940, p. 27. 
Pancho Rico Formation-Continued

Pinalito Canyon quadrangle

USGS loc. M2280 (field No. AG-64-1). In canyon $1,650 \mathrm{ft} \mathrm{N}$., $1,750 \mathrm{ft}$ E. of SW. cor. sec. 29 , T. $18 \mathrm{~S}$., R. 9 E. Fossils: mollusks, barnacles. Age: early Pliocene. Collector: W. O. Addicott, 1964. Reference: Durham and Addicott, 1965, table 1. Remarks: fauna listed in text.

Lonoak quadrangle

USGS loc. M2275 (field No. AHV-64-1). In roadcut, $100 \mathrm{ft} \mathrm{S}$., 2,400 ft E. of NW. cor. sec. 26 , T. $19 \mathrm{~S}$. R. 9 E. Fossils: mollusks, barnacles. Age: early Pliocene. Collector: W. O. Addicott, 1964.

USGS loc. M4006 (field No. 684042). On ridge, 200 ft S., $150 \mathrm{ft}$ E. of NW. cor. sec. 23, T. 19 S., R. 9 E. Fossils: brachiopods, mollusks, barnacles. Age: early Pliocene. Collector: D. L. Durham, 1968. Remarks: fauna listed in text.

Reliz Canyon quadrangle

USGS loc. M902 (field No. 601-5). In bluff on side of canyon, $650 \mathrm{ft} \mathrm{S.,} 1,875 \mathrm{ft} \mathrm{W}$. of NE. cor. sec. 35 , T. 19 S., R. 6 E. Fossils: foraminifers, brachiopods, mollusks, barnacles. Age: early Pliocene. Collectors: D. L. Durham, 1960; W. O. Addicott and D. L. Durham, 1964; R. L. Pierce, 1968. References: Durham, 1963, p. Q20; Durham and Addicott, 1965, table 1. Remarks: same as UC loc. 3953 mentioned in Hertlein and Grant (1944, p. 140); fauna listed in text.

USGS loc. M981 (field No. 601-173). On side of gully, $650 \mathrm{ft} \mathrm{N}$., $1,950 \mathrm{ft} \mathrm{W}$. of SE. cor. sec. $26, \mathrm{~T} .19 \mathrm{~S}$., R. 6 E. Fossils: brachiopods, mollusks, barnacles. Age: Pliocene. Collector: D. L. Durham and N. T. Durham, 1960. Reference: Durham, 1963, p. Q20; Durham and Addicott, 1965, table 1.

UC loc. 6010 (field No. 1112). About 1,050 ft S., 1,800 ft E. of NW. cor. sec. 36, T. 19 S., R. 6 E. Fossils: mollusks, barnacles. Collector: H. W. Lee, 1922. Reference: Lee, 1923, p. 15.

UC loc. 6011 (field No. 1113). About $100 \mathrm{ft} \mathrm{N}$., 700 ft E. of SW. cor. sec. 30, T. 19 S., R. 7 E. Fossils: mollusks. Collector: H. W. Lee, 1922. Reference: Lee, 1923, p. 15.

UC loc. 6012 (field No. 1114). About $1,700 \mathrm{ft} \mathrm{N}$. $1,950 \mathrm{ft} \mathrm{W}$. of SE. cor. $\sec 25$, T. 19 S., R. 6 E. Fossils: mollusks. Collector: H. W. Lee, 1922. Reference: Lee, 1923, p. 15.

UC loc. 6014 (field No. 1119). About $1,450 \mathrm{ft}$ N., $2,250 \mathrm{ft}$ E. of SW. cor. sec. 26, T. 19 S., R. 6 E. Fossils: mollusks. Collector: H. W. Lee, 1922. Reference: Lee, 1923, p. 15.

UC loc. 6015 (field No. 1120). About 2,100 ft N., 1,750 $\mathrm{ft}$ E. of SW. cor. sec. 26, T. 19 S., R. 6 E. Fossils: mollusks. Collector: H. W. Lee, 1922. Reference: Lee, 1923, p. 15.

Thompson Canyon quadrangle

USGS loc. M918 (field No. 584-468). On hillside, $2,000 \mathrm{ft} \mathrm{N}$., $1,475 \mathrm{ft} \mathrm{W}$. of SE. cor. sec. $23, \mathrm{~T} .20 \mathrm{~S}$., R. 7 E. Fossils: mollusks. Age: Pliocene. Collectors: D. L. Durham and R. P. Hunter, 1958. Reference: Durham, 1963, p. Q20; Durham and Addicott, 1965, table 1.

UC loc. B4923. About $800 \mathrm{ft} \mathrm{S.,} \mathrm{2,375} \mathrm{ft} \mathrm{E.} \mathrm{of} \mathrm{NW.}$ cor. sec. 14, T. 20 S., R. 7 E. Fossils: mollusks. Collector: R. M. Weidman, 1951-53. Reference: Weidman, 1958, p. 224.
Pancho Rico Formation-Continued

Thompson Canyon quadrangle-Continued

UC loc. B4924. About 2,250 ft S., 1,675 ft E. of NW. cor. sec. 14, T. 20 S., R. 7 E. Fossils: mollusks. Collector: R. M. Weidman, 1951-53. Reference: Weidman, 1958, p. 224.

USGS loc. M903 (field No. 594-414). In bluff, $425 \mathrm{ft}$ S., $425 \mathrm{ft} \mathrm{W}$. of NE. cor. sec. 5, T. 21 S., R. $9 \mathrm{E}$. Fossils: echinoids, mollusks, barnacles. Age: early Pliocene. Collectors: D. L. Durham, 1959; W. O. Addicott and D. L. Durham, 1964. Reference: Durham, 1963, table 1; Durham and Addicott, 1965, table 1. Remarks: fauna listed in text.

USGS loc. M912 (field No. P59-46). On hillside, 2,150 ft N. of SW. cor. sec. 9, T. 20 S., R. 9 E. Fossils: mollusks. Age: early Pliocene. Collector: P. J. Pattee, 1959. Reference: Durham, 1963, table 1.

USGS loc. M913 (field No. 601-3). In bluff on hillside, $2,650 \mathrm{ft} \mathrm{N}$., 1,075 ft E. of SW. cor. sec. 8, T. $20 \mathrm{~S}$., R. 9 E. Fossils: echinoids, mollusks, barnacles. Age: early Pliocene. Collector: D. L. Durham, 1960. Reference: Durham, 1963, table 1; Durham and Addicott, 1965, table 1.

USGS loc. M920 (field No. 601-1). On hillside, 2,825 ft N., 1,075 ft E. of SW. cor. sec. 8, T. 20 S., R. 9 E. Fossils: mollusks. Age: early Pliocene. Collector: D. L. Durham, 1960. Reference: Durham, 1963, table 1.

USGS loc. M952 (field No. 594-415). On hillside, 800 $\mathrm{ft}$ N., 2,250 ft E. of SW. cor. sec. 32, T. 19 S., R. 9 E. Fossils: mollusks. Age: early Pliocene. Collector: D. L. Durham, 1959. References: Durham, 1963, table 1; Durham and Addicott, 1965, table 1.

USGS loc. M987 (field No. P59-49). On hillside, 650 $\mathrm{ft} \mathrm{S.,} 850 \mathrm{ft}$ E. of NW. cor. sec. 16, T. 20 S., R. $9 \mathrm{E}$. Fossils: mollusks. Age: early Pliocene. Collector: P. J. Pattee, 1959. Reference: Durham, 1963, table 1.

USGS loc. M988 (field No. 594-407). On ridge crest, $3,150 \mathrm{ft} \mathrm{N}$., $325 \mathrm{ft} \mathrm{E}$. of SW. cor. sec. $28, T$. $19 \mathrm{~S}$., R. 9 E. Fossils: mollusks, barnacles. Age: early Pliocene. Collector: D. L. Durham, 1959. Reference: Durham, 1963, table 1.

USGS loc. M990 (field No. 602-333). In roadcut, 300 ft S., 1,500 ft W. of NE. cor. sec. 32, T. 19 S., R. 9 E. Fossils: mollusks, barnacles. Age: early Pliocene. Collector: D. L. Durham, 1960. Reference: Durham, 1963, table 1.

USGS loc. M2279 (field No. AKC-64-1). Pieces of rock near head of gully, 2,500 ft N., $300 \mathrm{ft} \mathrm{W}$. of SE. cor. sec. 8, T. 20 S., R. 9 E. Fossils: echinoids, mollusks, barnacles. Age: early Pliocene. Collector: W. O. Addicott, 1964. Reference: Durham and Addicott, 1965, p. A14, A20.

UC loc. A906. On N. wall of Wildhorse Canyon, 1,000 ft S. of NE. cor. sec. 8, T. 20 S., R. 9 E. Fossils: echinoids, mollusks. Reference: Durham and Addicott, 1965, table 1.

UC loc. A7570. About 2,600 ft N., 2,450 ft E. of SW. cor. sec. 33, T. 19 S., R. 9 E. Fossils: mollusks, barnacles. Collector: R. M. Weidman, 1951-53. Reference: Weidman, 1958, p. 224-225. Remarks: UC loc. A7571 is at about the same place. 
Pancho Rico Formation-Continued

San Lucas quadrangle-Continued

UC loc. A7572. About 1,550 ft N., 2,575 ft E. of $S W$. cor. sec. 33, T. 19 S., R. 9 E. Fossils: echinoids, mollusks. Collector: R. M. Weidman, 1951-53. Reference: Weidman, 1958, p. 225.

UC loc. A7573. About 1,350 ft N., 2,350 ft E. of SW. cor. sec. 33, T. 20 S., R. 9 E. Fossils: echinoids, mollusks. Collector: R. M. Weidman, 1951-53. Reference: Weidman, 1958, p. 224.

UC loc. B4921. About $675 \mathrm{ft} \mathrm{S.,} 125 \mathrm{ft} \mathrm{W}$. of NE. cor. sec. 36, T. 19 S., R. 8 E. Fossils: echinoids. Collector: R. M. Weidman, 1951-53. Reference: Weidman, 1958 , p. 224

UC loc. B4922. About $700 \mathrm{ft} \mathrm{N}$., 1,950 ft E. of $\mathrm{SW}$. cor. sec. 26, T. 19 S., R. 8 E. Fossils: mollusks. Collector: R. M. Weidman, 1951-53. Reference: Weidman, 1958, p. 224.

Nattrass Valley quadrangle

USGS loc. M2275 (field No. ASA-64-1). In gully, $1,900 \mathrm{ft} \mathrm{S}$., $900 \mathrm{ft} \mathrm{E}$. of NW. cor. sec. 14, T. $20 \mathrm{~S}$. R. 9 E. Fossils: mollusks, barnacles. Age: early Pliocene. Collector: W. O. Addicott, 1964. Remarks: probably near Terebratlia arnoldi quaylei locality mentioned by Hertlein and Grant (1944, p 123); fauna listed in text.

USGS loc. 3586. In Wildhorse Canyon, $\mathrm{NW}^{1 / 4} \mathrm{sec}$ 14, T. 20 S., R. 9 E. Fossils: barnacles. Reference: Woodring, Stewart, and Richards, 1940, p. 96.

Monarch Peak quadrangle

USGS loc. M2278 (field No. ASA-64-3). In roadcut, $22,500 \mathrm{ft} \mathrm{N}$., $13,750 \mathrm{ft} \mathrm{E}$. of $\mathrm{SW}$. cor. quadrangle, San Lorenzo (Randall) land grant. Fossils: mollusks. Age: early Pliocene. Collector: W. O. Addicott, 1964. Reference: Durham and Addicott, 1965, table 1. Remarks: fauna listed in text.

Cosio Knob quadrangle

USGS loc. M1060 (field No. 604227). On hillside, $2,325 \mathrm{ft} \mathrm{W}$. along sec. line from NE. cor. sec. $2, \mathrm{~T}$. 22 S., R. 7 E. Fossils: mollusks. Age: early (?) Pliocene. Collector: D. L. Durham, 1960. Reference: Durham, 1964, p. H16; Durham and Addicott, 1965, table 1.

USGS loc. M1062 (field No. 612129). On hillside, $4,225 \mathrm{ft} \mathrm{S}$., $425 \mathrm{ft} \mathrm{W}$. of NE. cor. sec. $33, \mathrm{~T} .21 \mathrm{~S}$., R. 7 E. Fossils: mollusks. Age: early (?) Pliocene. Collector: D. L. Durham, 1961. Reference: Durham, 1964 , p. H16.

USGS loc. M1063 (field No. 612132). On hillside, $4,275 \mathrm{ft} \mathrm{S}$., $600 \mathrm{ft}$ E. of NW. cor. sec. 34, T. $21 \mathrm{~S}$., R. 7 E. Fossils: mollusks. Age: Pliocene. Collector: D. L. Durham, 1961. Reference: Durham, 1964, p. H16.

USGS loc. M1065 (field No. 612193). On ridge crest, $13,200 \mathrm{ft} N$., $6,125 \mathrm{ft} E$. of $S W$. cor. quadrangle, Milpitas land grant. Fossils mollusks. Age: Pliocene. Collector: D. L. Durham, 1961. Reference: Durham, 1964, p. H16.

USGS loc. M1066 (field No. 612209). In artificial cut, $20,350 \mathrm{ft} \mathrm{N}$., 4,575 ft E. of SW. cor. quadrangle, Milpitas land grant. Fossils: mollusks. Age: Miocene or Pliocene. Collector: D. L. Durham, 1961. Reference: Durham, 1964, p. H16; Durham and Addicott, 1965, table 1 .
Pancho Rico Formation-Continued Cosio Knob quadrangle-Continued

USGS loc. M1067 (field No. 612256). On hillside, $9,275 \mathrm{ft} \mathrm{N}$., 2,475 ft $E$. of $\mathrm{SW}$. cor. quadrangle, Milpitas land grant. Fossils: mollusks. Age: Pliocene. Collector: D. L. Durham, 1961. Reference: Durham, 1964, p. H16; Durham and Addicott, 1965, table 1.

UC loc. A8968. About 2,900 ft W. of NE. cor. sec. 2, T. 22 S., R. 7 E. Fossils: mollusks. Collector: R. M. Weidman, 1951-53. Reference: Weidman, 1958, p. 225-226.

UC loc. B4919. About 2,800 ft S., 2,250 ft W. of NE. cor. sec. 30, T. 21 S., R. 7 E. Fossils: mollusks. Collector: R. M. Weidman, 1951-53. Reference: Weidman, 1958, p. 225.

UC loc. B4920. About 13,800 ft N., 9,700 ft E. of SW. cor. quadrangle, Milpitas land grant. Fossils: mollusks. Collector: R. M. Weidman, 1951-53. Reference: Weidman, 1958 , p. 225.

UC loc. B4925. About 10,000 ft N., 7,400 ft E. of SW. cor. quadrangle, Milpitas land grant. Fossils: mollusks. Collector: R. M. Weidman, 1951-53. Reference: Weidman, 1958, p. 223.

UC loc. B4926. About 10,000 ft N., 7,600 ft E. of SW. cor. quadrangle, Milpitas land grant. Fossils: mollusks. Collector: R. M. Weidman, 1951-53. Reference: Weidman, 1958, p. 223.

UC loc. B4927. About 9,900 ft N., 8,200 ft E. of SW. cor. quadrangle, Milpitas land grant. Fossils: mollusks. Collector: R. M. Weidman, 1951-53. Reference: Weidman, 1958, p. 223.

UC loc. B4928. About 10,150 ft N., 8,300 ft E. of SW. cor. quadrangle, Milpitas land grant. Fossils: mollusks. Collector: R. M. Weidman, 1951-53. Reference: Weidman, 1958, p. 223.

San Ardo quadrangle

USGS loc. M975 (field No. CR-98). On hillside, 300 $\mathrm{ft} \mathrm{S.,} 1,000 \mathrm{ft}$ E. of NW. cor. sec. 9, T. 22 S., R. $10 \mathrm{E}$. Fossils: echinoids, mollusks, barnacles. Age: early Pliocene. Collector: C. L. Rice, 1960. Reference: Durham and Addicott, 1965, table 1.

USGS loc. M996 (field No. CR-130-25). On ridgetop, $900 \mathrm{ft} \mathrm{S.,} 150 \mathrm{ft}$ E. of NW. cor. sec. 15, T. $21 \mathrm{~S}$., R. 10 E. Fossils: mollusks. Age: Pliocene. Collector: C. L. Rice, 1960. Reference: Durham and Addicott, 1965 , table 1 .

USGS loc. M4196 (field No. ACSA 69-1). On ridgetop, $1,900 \mathrm{ft} \mathrm{S}$., $1,675 \mathrm{ft} \mathrm{E}$. of NW. cor. sec. $18, \mathrm{~T}$. 22 S., R. 10 E. Fossils: mollusks, barnacles. Age: early Pliocene. Collectors: W. O. Addicott, D. L. Durham, and T. W. Dibblee, Jr., 1970.

USGS loc. M4197 (field No. ACSA 69-2). On crest of small knoll, 1,650 ft S., 1,300 ft E. of NW. cor. sec. 18, T. 22 S., R. 10 E. Fossils: mollusks. Age: probably late Miocene or Pliocene. Collectors: W. O. Addicott, Kôichirô Masuda, T. W. Dibblee, Jr., and D. L. Durham, 1970.

Loc. SA-17. About $500 \mathrm{ft} \mathrm{S.,} \mathrm{2,800} \mathrm{ft} \mathrm{W.} \mathrm{of} \mathrm{NE.} \mathrm{cor.}$ sec. 15, T. 21 S., R. 9 E. Fossils: mollusks. Collector: M. N. Bramlette, 1944. Reference: M. N. Bramlette, unpub. field notes dated Feb. 25, 1944. Remarks: other nearby localities that contain echinoids, mollusks, and barnacles as follows: SA-15, 
Pancho Rico Formation-Continued

San Ardo quadrangle-Continued $6,600 \mathrm{ft} \mathrm{S}$., 1,600 ft E. of NW. cor. quadrangle, San Bernardo land grant; $\mathrm{SA}-16,3,700 \mathrm{ft} \mathrm{W}$. of $\mathrm{NE}$. cor. sec. 15 , T. 21 S., R. 9 E.; SA-18, $1,600 \mathrm{ft} \mathrm{S.,}$ $1,000 \mathrm{ft} \mathrm{W}$. of NE. cor sec. 15, T. 21 S., R. 9 E.; SA-23, $100 \mathrm{ft}$ N., $1,600 \mathrm{ft} \mathrm{W}$. of SE. cor. sec. 10 , T. 21 S., R. 9 E. (M. N. Bramlette, unpub. field notes dated Feb. 25, 1944, and Mar. 2, 1944).

Pancho Rico Valley quadrangle

USGS loc. M976 (field No. CR-108). On ridge crest, $2,600 \mathrm{ft} \mathrm{S}$., $600 \mathrm{ft} \mathrm{W}$. of NE. cor. sec. 3, T. $22 \mathrm{~S}$., R. 10 E. Fossils: echinoids. Age: early Pliocene (J. W. Durham, written commun., 1960). Collector: C. L. Rice, 1960. Reference: Durham and Addicott, 1965, p. A19.

USGS loc. M977 (field No. 602-331). In bluff on S. side of Pancho Rico Creek, $950 \mathrm{ft} \mathrm{N}$., 3,100 ft W. of SE. cor. sec. 11, T. 22 S., R. 10 E. Fossils: mollusks. Age: early Pliocene. Collectors: D. L. Durham, W. Nash, R. Cooley, R. Newell, 1960; W. O. Addicott and D. L. Durham, 1963. Reference: Durham and Addicott, 1965, table 1. Remarks: same as USGS loc. M1939.

USGS loc. M979 (field No. 602-330). On hillside, $700 \mathrm{ft}$ S., $1,200 \mathrm{ft} \mathrm{W}$. of NE. cor. sec. 15, T. $22 \mathrm{~S}$., R. 10 E. Fossils: mollusks. Age: Pliocene. Collectors: D. L. Durham, W. Nash, R. Cooley, R. Newell, 1960. Reference: Durham and Addicott, 1965, table 1.

USGS loc. M980 (field No. 602-332). In bluff on S. side of Pancho Rico Creek, 1,550 ft N., 1,400 ft W. of SE. cor. sec. 11, T. 22 S., R. 10 E. Fossils: echinoids, mollusks, barnacles. Age: early Pliocene. Collectors: D. L. Durham, W. Nash, R. Cooley, and R. Newell, 1960; W. O. Addicott and D. L. Durham, 1963. Reference: Durham and Addicott, 1965, table 1. Remarks: same as USGS loc. M1929; fauna listed in text.

USGS loc. M2282 (field No. ASA-64-4). On gully side, $300 \mathrm{ft} \mathrm{N}$., $1,600 \mathrm{ft} \mathrm{E}$. of SW. cor. sec. 8, T. 22 S., R. 11 E. Fossils: echinoids, mollusks. Age: early Pliocene. Collector: W. O. Addicott, 1964. Reference: Durham and Addicott, 1965, table 1.

USGS loc. M2283 (field No. ASA-64-5). On hillside, $2,300 \mathrm{ft} \mathrm{S}$., 2,200 ft E. of NW. cor. sec. 8, T. $22 \mathrm{~S}$., R. 11 E. Fossils: mollusks, barnacles. Age: early Pliocene. Collector: W. O. Addicott, 1964. Reference: Durham and Addicott, 1965, table 1.

LSJU loc. 201. On ridge N. of Brown Canyon, sec. 12, T. 21 S., R. 10 E. Fossils: foraminifers. Reference: Cushman and Grant, 1927, p. 75.

Loc. SA-20. On ridge S. of Pancho Rico Creek, 2,000 ft N., $800 \mathrm{ft} \mathrm{W}$. of SE. cor. sec. 6, T. 22 S., R. 11 E. Fossils: echinoids, mollusks. Collector: M. N. Bramlette, 1944. Reference: M. N. Bramlette, unpub. field notes dated Feb. 25, 1944.

Loc. SA-21. In streambank, Lynch Canyon, $2,200 \mathrm{ft}$ N., 2,100 ft W. of SE. cor. sec. 3, T. 22 S., R. 11 E. Fossils: echinoids, mollusks. Collector: M. N. Bramlette, 1944. Reference: M. N. Bramlette, unpub. field notes dated Feb. 25, 1944.

Loc. SA-22. North of Sargent Canyon, $1,800 \mathrm{ft} \mathrm{S}$., $1,900 \mathrm{ft}$ E. of NW. cor. sec. 22, T. 22 S., R. $11 \mathrm{E}$. Fossils: mollusks. Collector: M. N. Bramlette, 1944. Reference: M. N. Bramlette, unpub. field notes dated Mar. 1, 1944.
Pancho Rico Formation-Continued

Slack Canyon quadrangle

UC loc. A3425. On ridge, NW $1 / 4$ sec. 9 , T. 22 S., R. 12 E. Fossils: echinoids, mollusks, barnacles. Reference: Durham and Addicott, 1965, table 1.

Williams Hill quadrangle

USGS loc. M1455 (field No. 622525). In roadcut, $4,775 \mathrm{ft} \mathrm{N}$., $18,300 \mathrm{ft} \mathrm{W}$. of $\mathrm{SE}$. cor. quadrangle, Los Ojitos land grant. Fossils: mollusks. Age: Pliocene. Collectors: D. L. Durham and D. C. Wiese, 1962. References: Durham, 1965a, p. Q17; Durham and Addicott, 1965, table 1.

Hames Valley quadrangle

USGS loc. M1676 (field No. 624225). On ridge crest, $1,050 \mathrm{ft} \mathrm{N}$., 2,500 ft W. of SE. cor. sec. 29, T. $22 \mathrm{~S}$., R. 10 E. Fossils: mollusks, barnacles. Age: Pliocene. Collectors: D. L. Durham and D. C. Wiese, 1962. References: Durham, 1966, p. B17; Durham and Addicott, 1965, table 1. Remarks: UC loc. A762 and LSJU loc. 1270 noted by Reinhart $(1943$, p. 65) in the NW $1 / 4 \mathrm{SE}^{1 / 4}$ sec. 29 , T. 22 S., R. 10 E., may be near USGS loc. M1676.

Wunpost quadrangle

USGS loc. M982. In roadcut, $150 \mathrm{ft} \mathrm{N}$., 2,525 ft W. of SE. cor. sec. 25 , T. 23 S., R. 10 E. Fossils: echinoids, mollusks, barnacles. Age: early Pliocene. Collectors: J. G. Vedder and C. A. Repenning, 1960. References: Durham, 1966, p. B17; Durham and Addicott, 1965; table 1 .

USGS loc. M983. In roadcut, $450 \mathrm{ft} N$., $2,525 \mathrm{ft} W$. of SE. cor. sec. 25, T. 23 S., R. 10 E. Fossils: mollusks. Age: Pliocene. Collectors: J. G. Vedder and C. A. Repenning, 1960. Reference: Durham, 1966, p. B17.

USGS loc. M1674 (field No. 624015). In creekbed, $475 \mathrm{ft} \mathrm{S}$., 2,525 ft E. of NW. cor. sec. 36, T. $23 \mathrm{~S}$., R. 10 E. Fossils: echinoids, mollusks. Age: probably early Pliocene. Collector: D. L. Durham, 1962. References: Durham, 1966, p. B17; Durham and Addicott, 1965, p. A14.

USGS loc. M1675 (field No. 624052). On hillside, $3,150 \mathrm{ft} \mathrm{S.,} \mathrm{1,925} \mathrm{ft} \mathrm{E.} \mathrm{of} \mathrm{NW.} \mathrm{cor.} \mathrm{sec.} 25$, T. $23 \mathrm{~S}$., R. 10 E. Fossils: mollusks. Age: Pliocene. Collector: D. L. Durham, 1962. Reference: Durham, 1966, p. B17.

USGS loc. M1934 (field No. 632052-9). In railroad cut, $550 \mathrm{ft} \mathrm{N}$., $175 \mathrm{ft}$ W. of SE. cor. sec. $25, T .23 \mathrm{~S}$., R. 10 E. Fossils: mollusks. Age: Pliocene. Collectors: W. O. Addicott and D. L. Durham, 1963. References: Durham, 1966, p. B17; Durham and Addicott, 1965, table 1.

USGS loc. M1935 (field No. 634001). On gully side, $900 \mathrm{ft} \mathrm{N}$., $850 \mathrm{ft}$ W. of SE. cor. sec. 28 , T. $22 \mathrm{~S}$., R. 11 E. Fossils: echinoids, mollusks, barnacles. Age: early Pliocene. Collectors: W. O. Addicott and D. L. Durham, 1963. References: Durham, 1966, p. B17; Durham and Addicott, 1965, table 1. Remarks: fauna listed in text.

USGS loc. M1970. In railroad cut, $425 \mathrm{ft} N$., $175 \mathrm{ft} \mathrm{W}$. of SE. cor. sec. 25, T. 23 S., R. 10 E. Fossils: mollusks, barnacles. Age: Pliocene. Collectors: W. O. Addicott and D. L. Durham, 1964. References: Durham, 1966, p. B17; Durham and Addicott, 1965, table 1. Remarks: about $40 \mathrm{ft}$ stratigraphically below USGS loc. M1934. 
Pancho Rico Formation-Continued

Valleton quadrangle

USGS loc. M1930 (field No. 632025). On hillside, $2,175 \mathrm{ft} \mathrm{S.,} \mathrm{2,100} \mathrm{ft} \mathrm{W.} \mathrm{of} \mathrm{NE.} \mathrm{cor.} \mathrm{sec.} \mathrm{9,} \mathrm{T.} 23 \mathrm{~S}$., R. 12 E. Fossils: mollusks, barnacles. Age: early Pliocene. Collector: D. L. Durham, 1963. References: Durham, 1966, p. B17; Durham and Addicott, 1965, table 1 .

USGS loc. M1933 (field No. 632029). On hillside, 225 ft S., $950 \mathrm{ft} \mathrm{W.} \mathrm{of} \mathrm{NE.} \mathrm{cor.} \mathrm{sec.} \mathrm{15,} \mathrm{T.} 23$ S., R. 12 E. Fossils: barnacles. Age: Pliocene (?) References: Durham, 1966, p. B17; Durham and Addicott, 1965, p. A20.

USGS loc. M1966 (field No. 641002). Near base of hill, $50 \mathrm{ft}$ N., 1,550 ft E. of SW. cor. sec. 36, T. $22 \mathrm{~S}$. R. 11 E. Fossils: echinoids, mollusks, barnacles. Age: early Pliocene. Collectors: W. O. Addicott and D. L. Durham, 1964. Reference: Durham, 1966, p. B17.

USGS loc. M1967 (field No. 641002-B). On ridge, $400 \mathrm{ft} \mathrm{S}$., 2,300 ft E. of NW. cor. sec. 1, T. $23 \mathrm{~S}$., R. 11 E. Fossils: mollusks. Age: Pliocene. Collectors: W. O. Addicott and D. L. Durham, 1964. References: Durham, 1966, p. B17; Durham and Addicott, 1965 , table 1.

USGS loc. M2281 (field No. ASM-61-1). On hillside, $600 \mathrm{ft} \mathrm{S.,} 1,050 \mathrm{ft}$ W. of NE. cor. sec. 26, T. $22 \mathrm{~S}$., R. 11 E. Fossils: echinoids, mollusks. Age: early Pliocene. Collector: W. O. Addicott, 1964.

UC loc. A914. SE. of Indian Valley in NE1/4 NE1/4 sec. 21, T. 23 S., R. 12 E. Fossils: mollusks. Reference: Durham and Addicott, 1965, table 1.

Loc. I-G. In ctr. W1/4 of SE $1 / 4 \mathrm{NE}^{1 / 4}$ sec. $27, \mathrm{~T} .22 \mathrm{~S}$., R. 12 E. Fossils: mollusks. Collector: N. L. Taliaferro, 1935. Reference: N. L. Taliaferro, unpub. field notes dated May 17, 1935.

Loc. SM-9. W. of Indian Valley, $50 \mathrm{ft}$ N., 2,000 ft W. of SE. cor. sec. 4, T. 23 S., R. 12 E. Fossils: echinoids, mollusks. Collector: M. N. Bramlette, 1944. Reference: M. N. Bramlette, unpub. field notes dated Feb. 26, 1944. Remarks: nearby localities as follows: SM-10, $50 \mathrm{ft}$ S., 1,900 ft W. of NE. cor. sec. 9, T. 23 S., R. 12 E.; SM-11, $300 \mathrm{ft} \mathrm{S.,} \mathrm{1,500} \mathrm{ft} \mathrm{W.}$ of NE. cor. sec. 9 , T. 23 S., R. 12 E. (M. N. Bramlette, unpub, field notes dated Feb. 26, 1944).

Loc. SM-13. On hillside, 2,000 ft S., 1,750 ft E. of NW. cor. sec. 36, T. 22 S., R. 11 E. Fossils: mollusks. Collector: M. N. Bramlette, 1944. Reference: M. N. Bramlette, unpub. field notes dated Mar. 1, 1944.

Bryson quadrangle

USGS loc. M3241 (field No. 664017). In bed of Copperhead Creek, $700 \mathrm{ft} \mathrm{S}$., 1,850 ft W. of NE. cor. sec. 18, T. 24 S., R. 9 E. Fossils: mollusks. Age: early Pliocene. Collectors: W. O. Addicott and D. L. Durham, 1967. Remarks fauna listed in text; fossil locality in figure 38.

USGS loc. M4191 (field No. 694010). In creek bottom, $8,950 \mathrm{ft} \mathrm{S.,} 4,700 \mathrm{ft} \mathrm{W}$. of NE. cor. quadrangle, Pleyto land grant. Fossils: mollusks. Age: late Miocene or early Pliocene. Collectors: D. L. Durham and R. J. McLaughlin, 1969.

Tierra Redonda Mountain quadrangle

USGS loc. M2307 (field No. 644280). In bluff on N. side of San Antonio River, 1,900 ft S., 3,425 ft W.
Pancho Rico Formation-Continued

Tierra Redonda Mountain quadrangle-Continued of NE. cor. sec. 29, T. 24 S., R. 10 E. Fossils: mollusks. Age: late Miocene or early Pliocene. Collector: D. L. Durham, 1964. Reference: Durham, 1968a, p. 35. Remarks: fossil locality in figure 39.

Bradley quadrangle

USGS loc. M2301 (field No. 644035). On ridge, 2,850 $\mathrm{ft}$ N., $725 \mathrm{ft}$ W. of SE. cor. sec. 15, T. 24 S., R. $10 \mathrm{E}$. Fossils: mollusks, barnacles. Age: Miocene or Pliocene. Collector: D. L. Durham, 1964. Reference: Durham, 1968a, p. 35.

USGS loc. M2302 (field No. 644063). Near base of hill, $1,825 \mathrm{ft} \mathrm{N}$., $1,400 \mathrm{ft} \mathrm{W}$. of SE. cor. sec. 26, T. 24 S., R. 10 E. Fossils: mollusks. Age: early Pliocene (?) Collector: D. L. Durham, 1964. Reference: Durham, 1968a, p. 35.

Ranchito Canyon quadrangle

USGS loc. M3998 (field No. 684025). On ridge, 1,150 $\mathrm{ft}$ N., 2,375 ft E. of SW. cor. sec. 7, T. 24 S., R. 14 E. Fossils: mollusks. Age: early Pliocene. Collector: D. L. Durham, 1968.

USGS loc. M3999 (field No. 684026). On ridge, 200 ft S., 2,550 ft E. of NW. cor. sec. 18, T. 24 S., R. 14 E. Fossils: echinoids, mollusks, barnacles. Age: early Pliocene. Collectors: D. L. Durham, 1968; W. O. Addicott and D. L. Durham, 1969. Remarks: fauna listed in text.

USGS loc. M4000 (field No. 684027). On ridge, 450 $\mathrm{ft}$ S., 2,550 ft E. of NW. cor. sec. 18, T. 24 S., R. 14 E. Fossils: echinoids, mollusks, barnacles. Age: early Pliocene. Collectors D. L. Durham, 1968; W. O. Addicott and D. L. Durham, 1969. Remarks, fauna listed in text.

Adelaida quadrangle

USGS loc. M2047 (field No. 642145). On canyon side, $550 \mathrm{ft} \mathrm{N}$., $225 \mathrm{ft} . W$. of SE. cor. sec. 19, T. $25 \mathrm{~S}$., R. 11 E. Fossils: mollusks. Age: late Miocene or early Pliocene. Collectors: W. O. Addicott, D. L. Durham, and R. J. McLaughlin, 1964. References: Durham, 1968b; Durham and Addicott, 1965, table 1.

USGS loc. M2050 (field No. 642147). On gully side, $2,225 \mathrm{ft} \mathrm{N}$., $1,250 \mathrm{~W}$. of SE. cor. sec. 29 , T. $25 \mathrm{~S}$., R. 11 E. Fossils: mollusks. Age: early Pliocene. Collectors: W. O. Addicott, D. L. Durham and R. J. McLaughlin, 1964. References: Durham, 1965b, p. D110; Durham, 1968b; Durham and Addicott, 1965, table 1. Remarks: fauna listed in text.

\section{REFERENCES CITED}

Adams, E. W., and Beatty, W. B., 1962, Bituminous rocks in California: California Div. Mines and Geology Mineral Inf. Service, v. 15 , no. 4 , p. 1-9.

Addicott, W. O., 1970, Tertiary paleoclimatic trends in the San Joaquin basin, California: U.S. Geol. Survey Prof. Paper 644-D, 19 p.

Anderson, F. M., and Martin, Bruce, 1914, Neocene record in the Temblor basin. California, and Neocene deposits of the San Juan district, San Luis Obispo County: California Acad. Sci. Proc., 4th ser., v. 4, p. 15-112.

Angel, Myron, 1890a, Monterey County [California]: California Mining Bur. 10th Ann. Rept. State Mineralogist, p. 345-348. 
Angel, Myron, 1890b, San Luis Obispo County [California]: California Mining Bur. 10th Ann. Rept. State Mineralogist, p. 567-585.

Antisell, Thomas, 1855 [On fossiliferous beds in San Luis Obispo County, Caliornia]: Caliornia Acad. Nat. Sci. Proc., v. 1, p. 34-35.

- 1856, Geological report [Parke's surveys in California and near thirty-second parallel]: U.S. Pacific Railroad Explor. (U.S. 33d Cong., 2d sess., S. Ex. Doc. 78, H. Ex. Doc 91), v. 7, pt. 2, 204 p.

Arnold, Ralph, and Johnson, H.R., 1910, Preliminary report on the McKittrick-Sunset oil region, Kern and San Luis Obispo Counties, Caliornia: U.S. Geol. Survey Bull. 406, $225 \mathrm{p}$.

Aubury, L. E., 1906, The structural and industrial materials of California: California Mining Bur. Bull, 38, p. 13-378.

Averill, C. V., 1947, Mines and mineral resources of San Benito County, California: California Jour. Mines and Geology, v. 43, no. 1, p. 41-60.

Bagg, R. M., Jr., 1905, Miocene Foraminifera from the Monterey Shale of California, with a few species from the Tejon Formation: U.S. Geol. Survey Bull. 268, 78 p.

Baldwin, T. A., 1949, San Ardo, a stratigraphic analysis [abs.]: Am. Assoc. Petroleum Geologists Bull., v. 33, no. 12, p. 2058.

1950, San Ardo-A stratigraphic analysis of a California oil field: Am. Assoc. Petroleum Geologists Bull., v. 34, no. 10, p. 1981-1989.

-1953, San Ardo field-A geologic case history: Jour. Petroleum Technology, v. 5, no. 1, sec. 1, p. 9-10; sec. 2, p.5.

Baldwin, T. A., and others, 1951, Salinas Valley cross section [abs.]: Am. Assoc. Petroleum Geologists Bull., v. 35, no. 12 , p. 2633.

Ball, M. W., 1951, The synthetic liquid fuel potential of California: Ford, Bacon and Davis, Inc., Report for [U.S.] Bur. Mines, p. 12-34.

Ball Associates, Ltd., 1965, Surface and shallow oil-impregnated rocks and shallow oil fields in the United States: U.S. Bur. Mines Mon. 12, 375 p.

Bandy, O. L., and Ingle, J.C., Jr., 1970, Neogene planktonic events and radiometric scale, California: Geol. Soc. America Spec. Paper 124, p. 131-172.

Bandy, O. L., Morin, R. W., and Wright, R. C., 1969, Definition of the Catapsydrax stainforthi Zone in the Saucesian Stage, California: Nature, v. 222, no. 5192 , p. 468-469.

Barger, R. M., and Zulberti, J. L., 1949, San Ardo oil field: California Oil Fields, v. 35, no. 2, p. 15-20.

Bell, G. L., 1940, A geologic section of the Santa Lucia Mountains, Coast Range, California: California Univ. (Berkeley), M.A. thesis, 54 p.

Bell, K. G., 1960, Uranium and other trace elements in petroleums and rock asphalts: U.S. Geol. Survey Prof. Paper 356-B, p. 45-65.

Berkstresser, C. F., Jr., 1968, Data for springs in the southern Coast, Transverse, and Peninsular Ranges of California: U.S. Geol. Survey open-file report.

Bishop, C. C., and Chapman, R. H., 1967, Bouguer gravity map of California, Santa Cruz sheet: California Div. Mines and Geology, scale 1:250,000.

Blake, W. P., 1855, Notice of remarkable strata containing the remains of infusoria and polythalmia in the Tertiary formation of Monterey, California: Acad. Nat. Sci. Philadelphia Proc., v. 7, p. 328-331 [1856].
1856, Observations on the physical geography and geology of the coast of California, from Bodega Bay to San Diego: U.S. Coast Survey, Rept. Supt. 1855, p. 376398.

1857, Geological report [Williamson's reconnaissance in California]: U.S. Pacific Railroad Explor. (U.S. 33d Cong., 2d sess., S. Ex. Doc. 78, H. Ex. Doc. 91), v. 5, pt. 2, 370 p.

Bradford, W. C., and Lawrence, E. D., 1956, San Ardo oil field: California Oil Fields, v. 42, no. 2, p. 27-31.

Bradley, W. W., and Logan, C. A., 1917, San Benito County, Chap. 2, in The counties of Monterey, San Benito, San Luis Obispo, Santa Barbara, Ventura, by W. W. Bradley, Emile Huguenin, C. A. Logan, and C. A. Waring, pt. 5 of Mines and mineral resources of portions of California: California Mining Bur., 15th Rept. State Minerologist, p. $616-673$.

Bramlette, M. N., 1946, The Monterey Formation of California and the origin of its siliceous rocks: U.S. Geol. Survey Prof. Paper 212, $57 \mathrm{p}$.

Bramlette, M. N., and Daviess, S. N., 1944, Geology and oil possibilities of the Salinas Valley, California: U.S. Geol. Survey Oil and Gas Inv. Prelim. Map 24, scale $1: 125,000$.

Burch, S. H., 1971, Complete Bouguer gravity and general geology of the Cape San Martin, Bryson, Piedras Blancas, and San Simeon quadrangles, California: U.S. Geol. Survey Prof. Paper 646-A, $12 \mathrm{p}$.

Burch, S. H., and Durham, D. L., 1970, Complete Bouguer gravity and general geology of the Bradley, San Miguel, Adelaida, and Paso Robles quadrangles, California: U.S. Geol. Survey Prof. Paper 646-B, 14 p.

Burch, S. H., Grannel, R. B., and Hanna, W. F., 1971 Bouguer gravity map of California, San Luis Obispo sheet: California Div. Mines and Geology, scale $1: 250,000$.

Burford, R. O., 1966, Strain analysis across the San Andreas fault and Coast Ranges of California: Acad. Sci. Fennicae Annales, ser. A., III, Geologica-Geographica 90, p. 99-110. 1968, Evidence of recent strain in the San Andreas fault system from triangulation surveys [abs.], in Conference on geologic problems of San Andreas fault system, Stanford, Calif., 1967, Proceedings: Stanford Univ. Pubs. Geol. Sci., v. 11, p. $87-88$.

California Division of Mines, 1955, Sand and gravel: California Div. Mines Mineral Inf. Service, v. 8, no. 12, p. 1-7. 1956, Gypsum: California Div. Mines Mineral Inf. Service, v. 9 , no. 6, p. 1-5.

California Oil Fields, 1947-1969, San Francisco, Calif., Summary of Operations, v. 33-55.

Campbell, H. A., 1948, San Ardo oil field [abs.]: Am. Assoc. Petroleum Geologists Bull., v. 32, no. 12, p. 2319.

Chester, A. H., 1896, A dictionary of the names of minerals, including their history and etymology: New York, John Wiley and Sons, $320 \mathrm{p}$.

Christensen, E. W., 1963, Petrography of some basement rocks in the King City area, in Guidebook to the geology of Salinas Valley and the San Andreas fault: Am. Assoc. Petroleum Geologists-Soc. Econ. Paleontologists and Mineralogists, Pacific Sec., Ann. Spring Field Trip, 1963, p. 110-112.

Church, H. V., 1963a, King City oil field, in Guidebook to the geology of Salinas Valley and the San Andreas fault: Am. Assoc. Petroleum Geologists-Soc. Econ. Paleontologists and Mineralogists, Pacific Sec., Ann. Spring Field Trip, 1963, p. 60-70. 
1963b, The King City oil field [abs.]: Pacific Petroleum Geologist, v. 17, no. 1, p. 2-3.

Clark, B. L., 1930, Tectonics of the Coast Ranges of middle California: Geol. Soc. America Bull., v. 41, no. 4, p. 747828.

1940, Two new Pliocene formations in California [abs.]: Geol. Soc. America Bull., v. 51, no. 12, pt. 2, p. 1956-1957.

Colvin, R. G., 1963, San Ardo oil field, Monterey County, California, in Guidebook to the geology of Salinas Valley and the San Andreas fault: Am. Assoc. Petroleum GeologistsSoc. Econ. Paleontologists and Mineralogists, Pacific Sec., Ann. Spring Field Trip, 1963, p. 57-59.

Compton, R. R., 1957, New Paleocene formation in the central Coast Ranges, California [abs.]: Geol. Soc. America Bull., v. 68 , no. 12 , pt. 2 , p. $1820-1821$.

1966a, Granitic and metamorphic rocks of the Salinian block, California Coast Ranges: California Div. Mines and Geology Bull. 190, p. 277-287.

1966b, Analyses of Pliocene-Pleistocene deformation and stresses in northern Santa Lucia Range, California: Geol. Soc. America Bull., v. 77, no. 12, p. 1361-1379.

Corey, W. H., 1954, Tertiary basins of southern California: California Div. Mines Bull. 170, chap. 3, p. 73-83.

Crawford, J. J., 1894, Mines and mining products of California: California Mining Bur. 12th Rept. State Mineralogist, p. $21-412$.

1896, Report of the State Mineralogist: California Mining Bur. 13th Rept. State Mineralogist, p. 10-646.

Curtis, G. H., Evernden, J. F., and Lipson, J. I., 1958, Age determination of some granitic rocks in California by the potassium-argon method: California Div. Mines Spec. Rept. 54, 16 p.

Cushman, J. A., and Grant, U. S., 4th, 1927, Late Tertiary and Quaternary elphidiums of the West Coast of North America: San Diego Soc. Nat. History Trans., v. 5, no. 6, p. 71-82.

Davis, C. H., 1912, The Los Burros mining district: Mining Sci. Press, v. 104, no. 20 , p. $696-698$.

Dickert, P. F., 1966, Tertiary phosphatic facies of the Coast Ranges: California Div. Mines and Geology Bull. 190, p. 289-304.

Dickinson, W. R., 1959, Structural relationships of Church Creek and Willow Creek faults, Santa Lucia Range, California [abs.]: Geol. Soc. America Bull., v. 70, no. 12, pt. 2, p. 1715.

1965, Tertiary stratigraphy of the Church Creek area, Monterey County, California: California Div. Mines and Geology Spec. Rept. 86, p. 25-44.

Durham, D. L., 1963, Geology of the Reliz Canyon, Thompson Canyon, and San Lucas quadrangles, Monterey County, California: U.S. Geol. Survey Bull. 1141-Q, 41 p.

1964, Geology of the Cosio Knob and Espinosa Canyon quadrangles, Monterey County, California: U.S. Geol. Survey Bull. 1161-H, 29 p.

- 1965a, Geology of the Jolon and Williams Hill quadrangles, Monterey County, California: U.S. Geol. Survey Bull. 1181-Q, 27 p.

1965b, Evidence of large strike-slip displacement along a fault in the southern Salinas Valley, California: U.S. Geol. Survey Prof. Paper 525-D, p. D106-D111.

1966, Geology of the Hames Valley, Wunpost, and Valleton quadrangles, Monterey County, California: U.S. Geol. Survey Bull. 1221-B, 53 p. -1968a, Geology of the Tierra Redonda Mountain and Bradley quadrangles, Monterey and San Luis Obispo Counties, California: U.S. Geol. Survey Bull. 1255, 60 p.

1968b, Geologic map of the Adelaida quadrangle, San Luis Obispo County, California: U.S. Geol. Survey Geol. Quad. Map GQ-768, scale 1:24,000.

1970 , Geology of the Sycamore Flat and Paraiso Springs quadrangles, Monterey County, California: U.S. Geol. Survey Bull. 1285, 34 p.

Durham, D. L., and Addicott, W. O., 1964, Upper Miocene and Pliocene marine stratigraphy in southern Salinas Valley, California: U.S. Geol. Survey Bull. 1194-E, 7 p.

1965, Pancho Rico Formation, Salinas Valley, California: U.S. Geol. Survey Prof. Paper 524-A, 22 p.

Durham, J. W., 1954, The marine Cenozoic of southern California: California Div. Mines Bull. 170, chap. 3, p. 23-31.

Eakle, A. S., 1914, Minerals of California: California Mining Bur. Bull. 67, 226 p.

Eldridge, G. H., 1901, The asphalt and bituminous rock deposits of the United States: U.S. Geol. Survey 22d Ann. Rept., pt. 1, p. 209-452.

-1903, Origin and distribution of asphalt and bituminous rock deposits in the United States: U.S. Geol. Survey Bull. 213 , p. 296-305.

English, W. A., 1918, Geology and oil prospects of the Salinas Valley-Parkfield area, California: U.S. Geol. Survey Bull. 691-H, p. 219-250.

Ernst, W. G., and Calvert, S. E., 1969, An experimental study of the recrystallization of porcelanite and its bearing on the origin of some bedded cherts: Am. Jour. Sci., Schairer Volume, v. 267-A, p. 114-133.

Fackler, J. H., 1953, Peculiarities of Aurignac sand accumulation in San Ardo field, Monterey County, California [abs.]: Am. Assoc. Petroleum Geologists Bull., v. 37, no. 1, p. 185.

Fairbanks, H. W., 1894, Geology of northern Ventura, Santa Barbara, San Luis Obispo, Monterey, and San Benito Counties [California]: California Mining Bur. 12th Rept. State Mineralogist, p. 493-526.

1895, The stratigraphy of the California Coast Ranges: Jour. Geology, v. 3, no. 4, p. 415-433.

1896, The possibilities of the petroleum industry in California: Eng. Mining Jour., v. 61, no. 25, p. 588.

1898 , Geology of a portion of the southern Coast Ranges: Jour. Geology, v. 6, no. 6, p. 551-576.

1900, The oil-yielding formations, in Monterey County, chap. 1, in Monterey, San Luis Obispo, and San Benito Counties, pt. 8 of Oil and gas yielding formations of California, by W. L. Watts: California Mining Bur. Bull. 19, p. 143-144.

1904a, Description of the San Luis quadrangle [California]: U.S. Geol. Survey Geol. Atlas, Folio 101.

1904b, Gypsum deposits in California: U.S. Geol. Survey Bull. 223, p. 119-123.

Fiedler, W. M., 1944, Geology of the Jamesburg quadrangle, Monterey County, California: California Jour. Mines and Geology, v. 40, no. 2, p. 177-250.

Franke, H. A., 1935, Mines and mineral resources of San Luis Obispo County, in San Francisco field district: California Jour. Mines and Geology, v. 31, no. 4, p. 402-461.

Galehouse, J. S., 1967, Provenance and paleocurrents of the Paso Robles Formation, California: Geol. Soc. America Bull., v. 78, no. 8, p. 951-978. 
Goldman, H. B., 1962, The Monterey Formation as a source of construction materials: California Assoc. Eng. Geologists, 5th Ann. Mtg., 1962, Tech. Papers, p. 57-62.

- 1964, Sand and gravel in California, an inventory of deposits, pt. B-central California: California Div. Mines and Geology Bull. 180-B, 58 p.

Galliher, E. W., 1931, Collophane from Miocene brown shales of California: Am. Assoc. Petroleum Geologists Bull., v. 15, no. 3, p. 257-269.

Goodyear, W. A., 1888, Petroleum, asphaltum, and natural gas: California Mining Bur. 7th Ann. Rept. State Mineralogist, p. 63-114.

Gower, H. D., 1966, Phosphate, in Mineral resources of California: California Div. Mines and Geology Bull. 191, p. 328-332.

Gower, H. D., and Madsen, B. M., 1964, The occurrence of phosphate rocks in California, in Geological Survey research 1964: U.S. Geol. Survey Prof. Paper 501-D, p. D79-D85.

Gribi, E. A., Jr., 1963a, Lynch Canyon oil field, Monterey County, California, in Guidebook to the geology of Salinas Valley and the San Andreas fault: Am. Assoc. Petroleum Geologists-Soc. Econ. Paleontologists and Mineralogists, Pacific Sec., Ann. Spring Field Trip, 1963, p. 72-73.

-1963b, Monroe Swell oil field, Monterey County, California, in Guidebook to the geology of Salinas Valley and the San Andreas fault: Am. Assoc. Petroleum GeologistsSoc. Econ. Paleontologists and Mineralogists, Pacific Sec., Ann. Spring Field Trip, 1963, p. 76-77.

Hail, W. J., Jr., 1957, Reconnaissance for uranium in asphaltbearing rocks in the western United States: U.S. Geol. Survey Bull. 1046-E, p. 55-85.

Haley, C. S., 1923, Gold placers of California: California Mining Bur Bull. 92, $167 \mathrm{p}$.

Hamlin, Homer, 1904, Water resources of the Salinas Valley, California: U.S. Geol. Survey Water-Supply and Irrigation Paper 89, $91 \mathrm{p}$.

Hanks, H. G., 1886, Mineral springs in California: California Mining Bur. 6th Ann. Rept. State Mineralogist, pt. 1, p. $57-76$.

Harland, W. B., Smith, A. G., and Wilcock, B., eds., 1964, Summary of the Phanerozoic time-scale, in The Phanerozoic time-scale, A symposium dedicated to Professor Arthur Holmes: Geol. Soc. London Quart. Jour., v. 120s, p. $260-262$.

Hart, E. W., 1966, Mines and mineral resources of Monterey County, California: California Div. Mines and Geology County Rept. 5, 142 p.

1968, [Remarks following, Structural and stratigraphic relations along the Nacimiento fault in the southern Santa Lucia Range and San Rafael Mountains, California, by J. G. Vedder and R. D. Brown, Jr.], in Conference on geologic problems of San Andreas fault system, Stanford, Calif., 1967, Proceedings: Stanford Univ. Pubs. Geol. Sci., v. 11, p. $258-259$.

Hertlein, L. G., and Grant, U. S., 4th, 1944, The Cenozoic Brachiopoda of western North America: California Univ. Los Angeles Pubs. Math. Phys. Sci., v. 3, 236 p.

Hess, F. L., 1920, California, in Gypsum deposits of the United States: U.S. Geol. Survey Bull. 697, p. 58-86.

Hill, J. M., 1923, The Los Burros district, Monterey County, California: U.S. Geol. Survey Bull. 735-J, p. 323-329.
Irelan, William, Jr., 1888, Report of the State Mineralogist: California Mining Bur. 8th Ann. Rept. State Mineralogist, $946 \mathrm{p}$.

Jenkins, O. P., 1943, Geomorphic provinces of California: California Div. Mines Bull. 118, p. 83-88.

Jennings, C. W., 1957, Asphalt and bituminous rock: California Div. Mines Bull. 176, p. 59-70.

Jennings, C. W., and Strand, R. G., 1958, Geologic map of California, Olaf P. Jenkins edition, Santa Cruz sheet: California Div. Mines, scale 1:250,000.

Kilkenny, J. E., 1948, Geology and exploration for oil in Salinas Valley, California: Am. Assoc. Petroleum Geologists Bull., v. 32, no. 12, p. 2254-2268.

Kilkenny, J. E., chm., and others, 1952, Cenozoic correlation section, Salinas Valley from San Antonio River northerly to San Andreas fault through San Ardo oil field, California: Am. Assoc. Petroleum Geologists, Pacific Sec., scale 1: 12,000 .

Kirwan, Richard, 1794, Elements of mineralogy, Earths and stones [2d. ed., v. 1]: London, printed by J. Nichols, for P. Elmsly.

Kleinpell, R. M., 1930, Zonal distribution of the Miocene Foraminifera in Reliz Canyon, California: Micropaleontology Bull., v. 2, no. 2, p. 27-32.

1938, Miocene stratigraphy of California: Tulsa, Okla., Am. Assoc. Petroleum Geologists, $450 \mathrm{p}$.

Kleinpell, R. M., Weaver, D. W., and Doerner, D. P., 1967, Glimpses of the Paleogene depositional record west, north, northeast, and east of the Gabilan Mesa, in Guidebook, Gabilan Range and adjacent San Andreas fault: Am. Assoc. Petroleum Geologists and Soc. Econ. Paleontologists and Mineralogists, Pacific Sec., p. 38-44.

Laizure, C. M., 1925a, Monterey County, in San Francisco field division: California Mining Bur. 21st Rept. State Mineralogist, p. 23-57.

1925b, San Luis Obispo County, in San Francisco field division: California Mining Bur. 21st Rept. State Mineralogist, p. 499-538.

Lawson, A. C., 1893, The post-Pliocene diastrophism of the coast of southern California: California Univ., Dept. Geology Bull., v. 1, no. 4, p. 115-160.

Lawson, A. C., chm., and others, 1908, The California earthquake of April 18, 1906. Report of the State Earthquake Investigation Commission: Carnegie Inst. Washington Pub. 87, v. 1, pts. 1, 2, 451 p., and Atlas.

Lee, H. W., 1923, Description of some new species together with notes on the stratigraphy of the upper Miocene and lower Pliocene of lower Reliz Creek, Monterey County, California: California Univ. (Berkeley), M.A. thesis, 15 p.

Loel, Wayne, and Corey, W. H., 1932, Paleontology, pt. 1 of The Vaqueros Formation, lower Miocene of California: California Univ. Pubs., Dept. Geol. Sci. Bull., v. 22, no. 3, p. 31-410.

Logan, C. A., 1917, San Luis Obispo County, chap. 3, in The Counties of Monterey, San Benito, San Luis Obispo, Santa Barbara, Ventura, by W. W. Bradley, Emile Huguenin, C. A. Logan, and C. A. Waring, pt. 5 of Mines and mineral resources of portions of California: California Mining Bur. 15th Rept. State Mineralogist, p. 674-726.

Mallory, V. S., 1959, Lower Tertiary biostratigraphy of the California Coast Ranges: Tulsa, Okla., Am. Assoc. Petroleum Geologists, $416 \mathrm{p}$. 
Mandra, Y. T., 1960a, Fossil silicoflagellates from California [abs.]: Dissert. Abs., v. 20, p. 4370.

1960b, Fossil silicoflagellates from California, U.S.A.: Internat. Geol. Cong., 21st, Copenhagen 1960, Rept., pt. 6 , Pre-Quaternary micropaleontology, p. 77-89.

1963, Buttle Diatomite, a new member of the Monterey Formation, Salinas Valley, California, in Guidebook to the geology of Salinas Valley and the San Andreas fault: Am. Assoc. Petroleum Geologists-Soc. Econ. Paleontologists and Mineralogists, Pacific Sec., Ann. Spring Field Trip, 1963, p. 104-105.

Merriam, C. W., 1941, Fossil turritellas from the Pacific Coast region of North America: California Univ. Pubs., Dept. Geol. Sci. Bull., v. 26, no. 1, p. 1-214.

Miller, H. O., 1953, San Ardo field-A history of development: Jour. Petroleum Technology, v. 5, no. 1, sec. 1, p. 11-13; sec. 2 , p. 5 .

Newsom, J. F., 1903, Clastic dikes: Geol. Soc. America Bull., v. 14 , p. $227-268$.

Nicholls, W. M., 1924, A geologic section across the middle Salinas Valley of California, from the San Antonio River to San Lorenzo Creek: California Univ. (Berkeley), M.A. thesis.

Nickell, F. A., 1931, Geology of the Soledad quadrangle, central California [abs.]: Geol. Soc. America Bull., v. 42, no. 1, p. 313-314.

Nomland, J. O., 1917, The Etchegoin Pliocene of middle California: California Univ. Pubs., Dept. Geology Bull., v. 10, no. 14, p. 191-254.

Oakeshott, G. B., 1957, Diatomite: California Div. Mines Bull. 176, p. $183-193$.

Pack, R. W., and English, W. A., 1915, Geology and oil prospects in Waltham, Priest, Bitterwater, and Peachtree Valleys, California: U.S. Geol. Survey Bull. 581, p. 119160.

Page, B. M., 1969, Relation between ocean floor spreading and structure of the Santa Lucia Range, California [abs.]: Geol. Soc. America Abstracts with Programs 1969, pt. 3, p. 51-52.

1970, Time of completion of underthrusting, Franciscan vs. Great Valley rocks, Santa Lucia Range, California [abs.]: Geol. Soc. America Abstracts with Programs, v. 2, no. 2, p. 129.

Peale, A. C., 1886, Lists and analyses of the mineral springs of the United States: U.S. Geol. Survey Bull. 32, 235 p.

Popenoe, W. P., Imlay, R. W., and Murphy, M. A., 1960, Correlation of the Cretaceous formations of the Pacific Coast (United States and northwestern Mexico): Geol. Soc. America Bull., v. 71, no. 10, p. 1491-1540.

Preston, E. B., 1893, Monterey County [California]: California Mining Bur. 11th Rept. State Mineralogist, p. 259-262.

Reed, R. D., 1925, The post-Monterey disturbance in the Salinas Valley, California: Jour. Geology, v. 33, no. 6, p. 588-607.

1927, Phosphate beds in the Monterey shales [abs.]: Geol. Soc. America Bull., v. 38, no. 1, p. 195-196.

Reinhart, P. W., 1943, Mesozoic and Cenozoic Arcidae from the Pacific slope of North America: Geol. Soc. America Spec. Paper 47, $117 \mathrm{p}$.

Rintoul, Bill, 1961, Hot time in the oil patch: Western Oil and Refining, v. 58, no. 8, p. 22, 24-25.

1964, Full steam ahead in California: California Oil World, v. 57, no. 13, p. 1-6.
1965, The steam story-Some case histories: California Oil World, v. 58, no. 10, p. 1-2, 4-5.

1966a, Thermal recovery, steam-in situ burning: California Oil World, v. 59, no. 2, p. 18-38.

1966b, San Ardo, showcase for thermal recovery: California Oil World, v. 59, no. 4, p. 1-4.

1967, Thermal recovery-The steam story: California Oil World, v. 60, no. 2, p. 48-63.

Schenck, H. G., 1936, Nuculid bivalves of the genus Acila: Geol. Soc. America Spec. Paper 4, 149 p.

Schenck, H. G., and Childs, T. S., Jr., 1942, Significance of Lepidocyclina (Lepidocyclina) californica, new species, in the Vaqueros Formation (Tertiary), California: Stanford Univ. Pubs. Geol. Sci., v. 3, no. 2, p. 5-57.

Schombel, L. F., 1940, Preliminary report on the geology of the Soledad quadrangle, Monterey County, California: California Univ. (Berkeley), M.A. thesis.

1943, Soledad quadrangle: California Div. Mines Bull. 118, p. 467-470.

Simm, C. N., 1964, How combustion drive projects are performing in California: World Oil, v. 159, no. 5, p. 151-154, 204.

Smith, F. E., Jr., 1963, Paris Valley oil field, Monterey County, California, in Guidebook to the geology of Salinas Valley and the San Andreas fault: Am. Assoc. Petroleum Geologists-Soc. Econ. Paleontologists and Mineralogists, Pacific Sec., Ann. Spring Field Trip, 1963, p. 79-81.

Smith, P. B., 1968, Paleoenvironment of phosphate-bearing Monterey Shale in Salinas Valley, California: Am. Assoc. Petroleum Geologists Bull., v. 52, no. 9, p. 1785-1791.

Smith, P. B., and Durham, D. L., 1968, Middle Miocene Foraminifera and stratigraphic relations in the Adelaida quadrangle, San Luis Obispo County, California: U.S. Geol. Survey Bull. 1271-A, 14 p.

Stalder, Walter, 1924, A section of the Monterey (Salinas) shales in Pine Canyon, Monterey County, California: Am. Assoc. Petroleum Geologists Bull., v. 8, no. 1, p. 55-60.

Stanton, T. E., 1948, Correlation of laboratory tests with field experiences of excessive concrete expansion induced by a reaction between the cement and aggregate: Am. Soc. Testing Materials Proc., v. 48, p. 1057-1066.

Stanton, W. L., Jr., 1931, Geology of the Adelaida quadrangle, California: California Inst. Technology, Pasadena, Ph.D. thesis.

Taggart, Larry, and Kraetsch, R. B., 1963, Fossil register of Salinas Valley area, in Guidebook to the geology of Salinas Valley and the San Andreas fault: Am. Assoc. Petroleum Geologists-Soc. Econ. Paleontologists and Mineralogists, Pacific Sec., Ann. Spring Field Trip, 1963, p. 54.

Taliaferro, N. L., 1934, Contraction phenomena in cherts: Geol. Soc. America Bull., v. 45, no. 2, p. 189-232.

1943a, Geologic history and structure of the central Coast Ranges of California: California Div. Mines Bull. 118, p. 119-163.

1943b, Bradley-San Miguel district: California Div. Mines Bull. 118, p. 456-462.

1944, Cretaceous and Paleocene of Santa Lucia Range, California: Am. Assoc. Petroleum Geologists Bull., v. 28, no. 4, p. 449-521.

Taliaferro, N. L., and Schenck, H. G., 1933, Lepidocyclina in California: Am. Jour. Sci., 5th ser., v. 25, no. 145, p. 74-80.

Tarr, W. A., 1938, Terminology of the chemical siliceous sediments, Exhibit A of Report of the Committee on Sedimentation, 1937-1938: Natl. Research Council, p. 8-27. 
Thorup, R. R., 1941, Vaqueros Formation (Tertiary) at its type locality, Junipero Serra quadrangle, Monterey County, California [abs.]: Geol. Soc. America Bull., v. 52, no. 12, pt. 2, p. 1957-1958.

1942, The stratigraphy of the Vaqueros Formation at its type locality, Monterey County, California: Stanford Univ., Stanford, Calif., M. A. thesis.

1943, Type locality of the Vaqueros Formation: California Div. Mines Bull. 118, p. 463-466.

1948, Recent developments in Salinas Valley [abs.] Am. Assoc. Petroleum Geologists Bull., v. 32, no. 12, p. 2317,2319

1961, King City oil field, Monterey County, California [abs.]: Am. Assoc. Petroleum Geologists Bull., v. 45, no. 1, p. 130.

Trask, J. B., 1854, Report on the geology of the Coast Mountains and part of the Sierra Nevada, embracing their industrial resources in agriculture and mining: [California] Assembly Doc. 9, Sess. 1854, 95 p.

Trask, P. D., 1926, Geology of Point Sur quadrangle, California: California Univ. Pubs., Dept. of Geol. Sci. Bull., v. 16 , no. 6 , p. 119-186.

U.S. Geological Survey, 1964, Compilation of records of surface waters of the United States, October 1950 to September 1960, pt. 11, Pacific slope basins in California: U.S. Geol. Survey Water-Supply Paper 1735, 715 p.

U.S. Geological Survey and California Division of Mines and Geology, 1966, Geologic map of California: U.S. Geol. Survey Misc. Geol. Inv. Map I-512, scale 1:2,500,000.

Vander Leck, Lawrence, 1921, Petroleum resources of California, with special reference to unproved areas: California Mining Bur. Bull. 89, 186 p.

1922, Memoranda on asphalt and bituminous sand deposits of California: California Mining Bur. 18th Rept. State Mineralogist, p. 228-230.

Van Gundy, C. E., 1934, The relations of the Upper Cretaceous and Martinez Formations in the northern part of the Adelaida quadrangle: California Univ. (Berkeley), M.A. thesis, $60 \mathrm{p}$.

Ver Planck, W. E., 1952, Gypsum in California: California Div. Mines Bull. 163, 151 p.
1957, Gypsum: California Div. Mines Bull. 176, p. 231240.

Wardle, W. C., 1957, Eocene Foraminifera from the Lucia Shale: California Univ. (Berkeley), M.A. thesis.

Waring, C. A., 1914, Geology and possibilities of oil in portions of Monterey, San Luis Obispo, and San Benito Counties, Chap. 10, in McLaughlin, R. P., Petroleum industry of California: California Mining Bur. Bull. 69, p. 418-438.

Waring, C. A., and Bradley, W. W., 1917, Monterey County, Chap. 1 in The counties of Monterey, San Benito, San Luis Obispo, Santa Barbara, Ventura, by W. W. Bradley, Emile Huguenin, C. A. Logan, and C. A. Waring, pt. 5 of Mines and mineral resources of portions of California: California Mining Bur. 15th Rept. State Mineralogist, p. 595-615.

Waring, G. A., 1915, Springs of California: U.S. Geol. Survey Water-Supply Paper 338, 410 p.

Weaver, C. E., chm., and others, 1944, Correlation of the marine Cenozoic formations of western North America, Chart no. 11: Geol. Soc. America Bull., v. 55, no. 5, p. 569-598.

Weidman, R. M., 1958, Geology of the King City quadrangle, California: California Univ. (Berkeley), Ph.D. thesis, $225 \mathrm{p}$.

Whitney, J. D., 1865, Report of progress and synopsis of the fieldwork from 1860 to 1864: California Geol. Survey, Geology, v. 1, 498 p.

Wiebe, R. A., 1970, Pre-Cenozoic tectonic history of the Salinian block, western California: Geol. Soc. America Bull., v. 81, no. 6 , p. 1837-1842.

Wilkinson, E. R., 1964, Lynch Canyon oil field: California Oil Fields, v. 50, no. 2, p. 79-85.

1965, McCool Ranch oil field: California Oil Fields, v. 51 , no. 2 , p. $75-80$.

Williams, Howel, Turner, F. J., and Gilbert, C. M., 1954, Petrography, an introduction to the study of rocks in thin sections: San Francisco, Calif., W. H. Freeman and Co., $406 \mathrm{p}$.

Woodring, W. P., Stewart, Ralph, and Richards, R. W., 1940, Geology of the Kettleman Hills oil field, California: U.S. Geol. Survey Prof. Paper 195, 170 p.

Zullo, V. A., 1969, Thoracic Cirripedia of the San Diego Formation, San Diego County, California: Los Angeles County Mus. Contr. Sci., no. 159, 25 p. 


\section{INDEX}

[Italic page numbers indicate major references]

Page

Acanthina n. sp . Acknowledgments Acteon sp Addicott, Warren, cited ...................... 5, 18, 25, 29, $30,31,47,48,51,54,56,83$ Adelaida Adelaida quadrangle ............ 4, 18, 22, 28, 41, 42 , $48,52,55,57,60,61,63,65,75$

Ages, radiometric .

Allomorphina cretacea

Alluvium

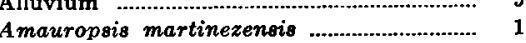

Ammodiscus incertus ......................................

Ampullaspira martinezensis ....................... 16

Ampullina concipio ........................................ 18

Amussiopecten vanvlecki ................................ $\quad 30$

Anadara ......................................................

camulosengis .............................................. 53

montereyana ........................................... 47

trilineata ...................................... 51, 53

canalis ............................................ 53

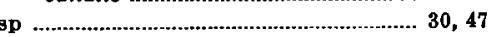
(Anadara) trilineata ............................ 52

Anchura sp .................................................. 18

Angulogerina sp ........................................... 44

Anomalina glabrata ........................................ 43 patella ..................................................... 42

regina

salinasenoio $42,43,44$

Anomia vaquerosensis ............................... 27

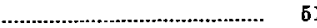

Antillophos posunculensis ........................... 30

Arca santamariensis ..................................... 47

Arch, reconstructed ................................. 11, 73, 74

Arroyo Seco ……...... 4, 5, 6, 7, 9, 25, 28, 31, 35, $40,41,48,50,54,69,70,74,81,82$

drainage area ................................ 75 Asphalt .

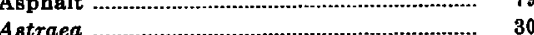

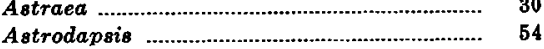
arnoldi ...................................................... 52, 53 fernandoensis .................................... 51, 53 spatiosus

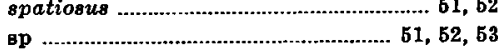
Asuncion Formation .................................. 16, 19 Asuncion Group ........................................... 16, 19 Atascadero 45,61

Atascadero Formation ……............................... 16, 43 Atascadero Formation $\ldots \ldots \ldots \ldots \ldots \ldots \ldots \ldots \ldots \ldots . . \ldots \ldots \ldots$
Atascadero quadrangle Atrina sp

Baculites sp ................................................... 19 Baggina californica ................................. 42, 44 cancriformia .................................... 42, 43, 44 robusta

Baja California ............................................. 31

Balanus ............................................................. gregarius .................................. 47, 51, 52, 53 sp ................................................. 52, 57

Ball Associates, Ltd ...................................... 79

Bandini Petroleum Doud 54X-19 well ........ 78

Barnacles ….................... 30, 47, 51, 52, 53, 54, 57 Basalt ....

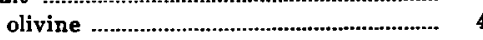

Basement complex, pre-Tertiary .......... 4, 12, 20, $22,25,29,45,47,48,51,55,58,61$. $63,67,69,70,71,75,79,81$

Salinian block …............................... 16,71 Basement complex surface.

relief features …....... $72,74,78,80$

Bathysiphon sp elief features …....... $72,74,78,80$

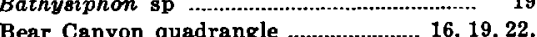
$24,25,27,35,50,60,82$ Bee Rock $24,25,27,35,50,60,82$ Bee Rock fault .............................................. 61 Bee Rock fault zone ................................... 60,61 Bentonite ..................................................... 36 Berry Conglomerate ..................................... 22 type locality ........................................ 22

Berry Formation ......................................... 21, 22

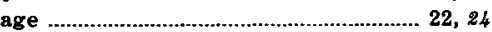
deposition ................................................ 24

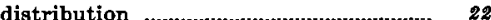
lithology .................................................... 24 nomenclature ............................................ 22 stratigraphic relations …...................... 21, 24 thickness …............................................ 22 Biotite ............................................ 18, 21, 25 Bittium casmaliense ….........................52, 54

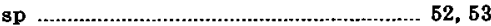

Bituminous rock .............................. 39, 75, 78 Bituminous Slate series .............................. 31

Bolivina advena.

advena striatella ................................42, 43, 44 brevior .................................................42, 43

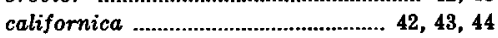
conica .................................................. 42, 44 cuneiformis ...................................... 42, 43, 44 eurta guadaloupae ................................................... 42, 43 imbricata ............................................ 42, 44 marginata ...................................... 42, 43, 44 adelaidana ....................................... 43 gracillima ........................................... 42 ovata …........................................... 44

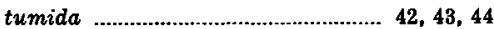
Brachiopods …........................... 47, 51, 53, 57 Bradley ............................................. 54, 55, 57 Bradley quadrangle .............................. $32,39,47$, $61,65,74,75,79,80,82$ Bramlette, M. N., quoted ........................ 35 Bruclarkia barkeriana .................................. 30 Bryson quadrangle ............................ 19, 25, 27, Bulimina alligata $42,43,53,60,63,80,82$

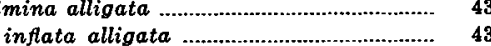
montereyana ......................................... 43, 44 ovula pseudoafinis pseudotorta ................................................ 42 rinconensis ......................................... 42, 43

Buliminella curta ................................... 42, 43, 44 curtissma ................................................. 21 grata convoluta ....................................... 21 subfusiformis .................................. 42, 43, 44 Burford, R. O., cited ................................... 73 Buttle Canyon ................................................. Buttle Diatomite ............................................. 32 type locality
Buttle Member …………..................... 31, 32, 63

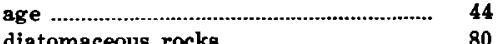
fossils

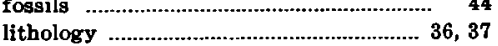

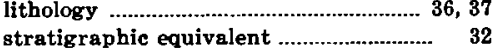
stratigraphic relations ............ 41, 45, 48, 51

\section{C}

C. A. Luckey Sinclair 5 well ......................... 78 Calcite ........................................................ 55 Calicantharus fortis ....................................... 52, 53

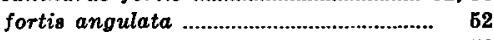
humerosus ................................................ 62 kettlemanensis ................................ 52, 53, 54

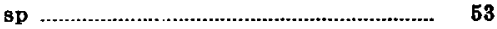

Calliostoma cammani ................................... 51 coalingense …........................................ 51, 53 etchegoinense ......................................... 53 alyptraea filosa .............................. 47, 51, 52, 53 sp ...................................................... 47, 51, 52, 53 Camp Roberts ................................... 4, 55, 57 Campanian Stage ......................................... 19 Cancellaria dalliana ................. 30 fernandoensis ...................................... 52, 53 rapa perrini ......................................... 53 (Euclia) n. sp. aff.

$$
C \text {. }(E .) \text { oregonensis }
$$

sp ........... 47, 51

Cancris baggi .............................................. 42

Carbon isotope analysis ............................... 58

Cardiid

Cardium lintium ..........

16 panzana ............................................. 43 pulchella ................................................... 42 williami ..................................................... 43

Cephalopods …….......................................... 19

Ceratostoma foliatum ..................................... 51 nuttalli .............................................. 51 Chalcedony .................................................. $55,50,55$ Chert …........ 35, $37,46,50,51,55,74,75$

Chico Group .

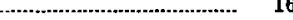

Chilostomella sp ............................................... 43

Chione fernandoensis .................................. 51 semiplicata...

temblorensis ...

(Chionopsis) sp

Chlamys hertleini$$
\text { hodgei }
$$

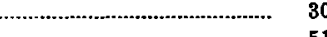

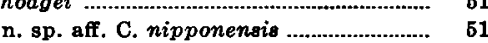

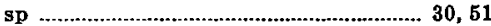

Christensen, E. W., cited ............................. 12, 15

Cibicides americanus ............................... 42, 43, 44

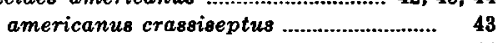
relizensis ................................................ 43, 44 spiropunctatus ….................................... 21

Clasts, composition .......................................... 71

Clavus coalingensis ...................................... 52, 54

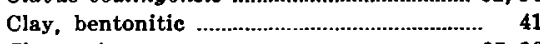

Clementia ...................................................... 27, 28

Clinocardium hannibali ................................. meelkianum …..................................... 54

Coalinga district, Calif ....................................... 54

Coast Ranges, southern ............................ 2, 4, 58

Coleman Canyon ............................................ 16, 24

Collection-locality descriptions ...................... 82 


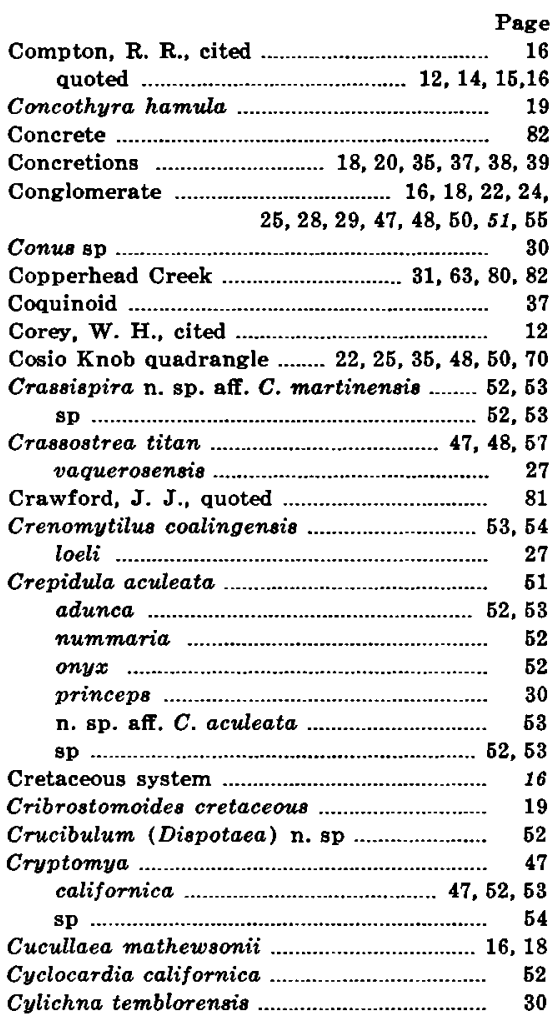

Danian Stage Deformation ...................................60, 63, 67, 73 Dendraster ................................................... 54

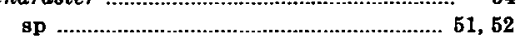
Dentalina consobrina .............................. 42 multilineata ............................................... 21 obliqua

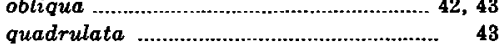
Dentalium sp ...................................................... 19 Deposition, marine ....................................... 71, 72 Diabase ......................................................... 41 Diatomaceous mudstone ………………... 37, 72 Diatomaceous rocks ................... 32, 35, $37,41,51$ Diatomite ..................................... 37, 48, 50, 75, 80 mine …............................................ 80 Diatoms ……....................... 37, 39, 41, 42, 51, 57 Dickinson, W. R., cited .......................... 18, 70 Dictyomitra multicostata ............................... $\quad 19$ Diodora sp ........................................... 51

Dip Creek Formation ..................................... 16 Diacinisca cumingi …................................. 47

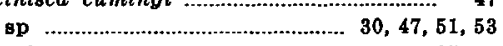

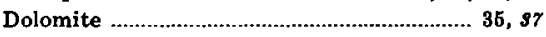
Dorothia ellisorae ........................................... 19

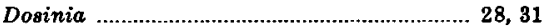
merriami …............................................ 30, 47 ponderosa ................................................. 53 sp ....................................................... 47

Drainage pattern .................................. 9 radial ..................................................... 74, 75 Dunes ……............................................... 58, 74 Durham, J. Wyatt, cited ............................ 5, 12

Echinoids ................... 27, 30, 47, 51, 52, 53, 54 Economic geology bituminous rock diatomite gold . gravel gypsum

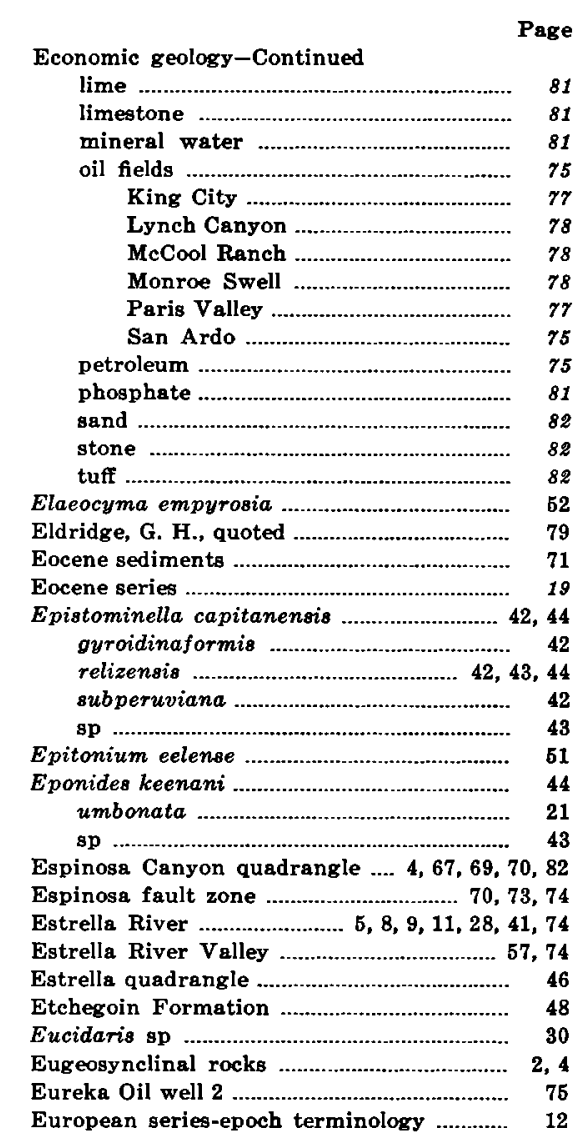

\section{F}

Fairbanks, H. W., cited

80

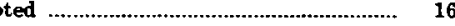

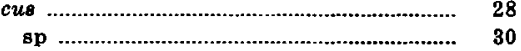
Florimetis biangulata ................................... 47, 52, 53 sp ……................................................. 54

Forreria belcheri …............................51, 52, 53 coalingensis ........................................ 51, 53 sp ............................................... 53 Foraminifers $. \ldots \ldots \ldots \ldots, 18,19,22,28$. orbitoid ... 30

Fossils, localities .................................................. 12, 18

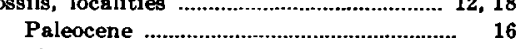

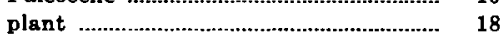

Franciscan Formation ............................ 2, 4, $12,16,18,55,58,60,71$
chert $\ldots \ldots \ldots \ldots$

G

Gabilan high ...................................... 47, 67, 69, $70,72,73,74,75,77,78$ Gabilan Range ............................... 11, 67, 70, 81 Galehouse, J. S., cited .................................... $\quad 66$ quoted ..................................................... 57

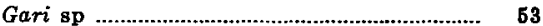

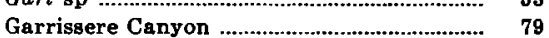

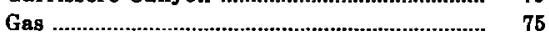

Gastropods ......... 18, 19, 27, 30, 47, 51, 62, 63, 57

Gaudryina bentonensis ................................ 19 tailleuri

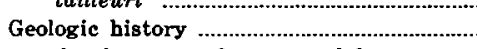
development of structural features ....

sedimentation

structural interpretation

summary of topography
Geologic investigations, previous Page

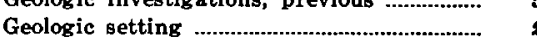

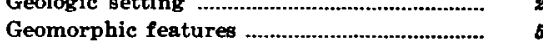

Glans n. sp. aff. G. radiata ..........................

Glauconite .....................................................

Globigerina soldadoensis yeguaensia ........... 21

Globigerinids .........................................42, 43, 44

Globorotalia aragonensis ................................ 22 broedermanni ............................................... 22 quetra .................................................. 22

Glycymeris ............................................ 19, 30

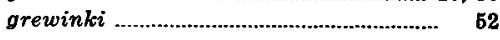
op ……............................................. 51, 52 Gold …...................................................... 75, 80

Granite dikes ............................................ 15

Granitic rocks ............................................... 2, 14, 51

Gravel …........................................... 75, 82

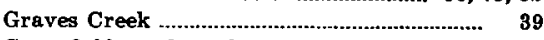

Greenfield quadrangle ....................................... 78

Gulf of California ...................................... 31

Gypsum ........................... 36, 55, 58, 72, 75, 81

Gyroidina reliziana ................................ 42, 43 rotundimaroo ................................................... 42

$\mathbf{H}$

Hames Member .................................. 28, 31, 32

age ........................................................ 44

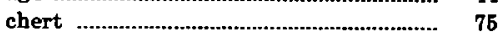
deposition ................................................ 44 fossils ............................................. 41, 42, 44 lithology ................................... 35, 36, 37, 39 pellet phosphate ....................................... 82 porcelaneous rocks .......................... 61, 75, 82 reference locality ...................................... 32 stratigraphic equivalent .......... 32, 45, 75, 78 stratigraphic relations .........................41, 45, $46,47,48,61,75,79$ structural features .................................. 61

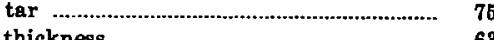

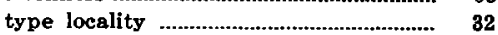
Hames Valley ............ 31, 32, 35, 60, 67, 69, 73, 80 Hames Valley quadrangle ........................ 4, 32.

$58,69,70,73,75$ ................................. 19, 24 Haplophragmoides excavatus ..................... 19 Harris Creek .................................................. 39, 41

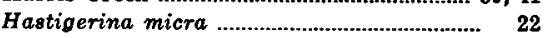
Hastula gnomon ............................................... 30

Here excavata .................................................... 52

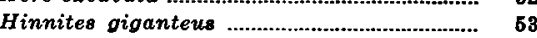

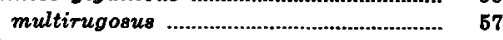

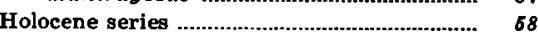
Horse Canyon ….............................................. 81 Huerhuero Creek ............................................... 71 Huerhuero fault ....................................... 69, 71, 73

Imperial mammoth ........................................... Indian Creek …..................................................... 44, 82 Indian Valley ............. 9, 35, 51, 67, 67, 74, 78 Infusorial earth .............................................. 82

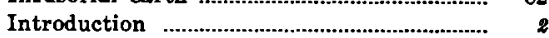

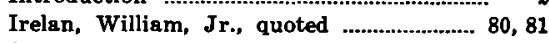
Israelsky, Merle, cited .................................... 5 Irvingtonian Stage ........................................... $\quad 68$

\section{$\mathbf{J}$}

Jacalitos Formation ...................................... 48 Jack Creek ….................................................. 41, 82 Jack Creek Formation ............................... 16, 19 Jamesburg quadrangle ................................. 70 Jolon ........................................................... 8, 80 Jolon fault ....................46, 47, 48, 60, 61, 66, 73 Jolon quadrangle ........................................ 4, 60 
Page

Jolon-Rinconada fault zone ...... 11, 12, 58, 60, 67 basement complex, configuration ........ 67 Bee Rock fault zone …........... 61

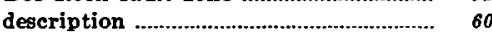
displacement ........................................65, 65 northeast area ….............................67, 67,75 faults ......................................... 70,73 southwest area ...........................................60, 60 Juniperan (Penutian) Stage .................... 22 Junipero Sandstone ........................................ 19 Junipero Serra high ............67, 69, 70, 72, 73, 75 Junipero Serra Peak quadrangle ......... 4, 19, 21 , $22,40,42,67,81,82$

\section{$\mathbf{K}$}

Karreriella arenasensis

Kelletia kelleti

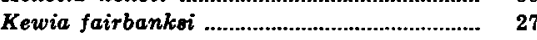

King City ……............... 7, 48, 64, 58, 75, 78, 79

King City fault

King City Formation ......... 48

King City

Knoxville Group

\section{$\mathbf{L}$}

La Panza higb

$67,69,70,72$

La Panza Range

$5,29,31$,

$32,45,67,60,69,74$

Laizure, C. M., cited

Land surfaces, old ................................. 9, 73, 74, 75

Landforms

Las Tablas Creek

Lawson, A. C., quoted

Lenticulina miocenica

miocenica smileyi

miocenicus

reedi

oimplex

sp

Lepidocyclina

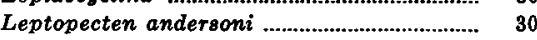

Lignite .................................................... 55, 58

Lima hemphilli

57,81

Lime Mountain quadrangle ............. 18, 30, 41, 43

Limestone ...................................... 18, 55, 58, 81

Lirophora n. sp .

Location Lockwod bigh ..............47, 66, 67, 69, 70, 71, 72, 73

Long Valley

7,9

Lonoak quadrangle .................................... 63, 54

Los Lobos fault .......................................... 70

Lowes Canyon .................................................... 57

Loxostomum applinae ...................................... 22

Lucia Shale .................................................. 19

Lucinisca

n. sp. aff. $L$. nuttalli ......... 47, 51, 52, 53, 54 sp ............................................................. 63

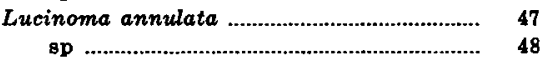
Luisian Stage ................................25, 30, 31, $41,42,43,44,57,63,72$

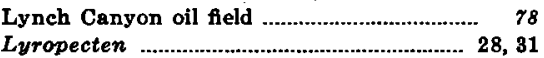

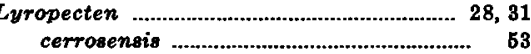
crassicardo ................................................ 30 estrellanus ................................47, 48, 51, 52

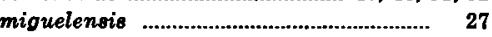
terminus ................................................. 52, 53, 54

Macoma arctata ........................................... $\quad 30$ astori indentata ............................................ 52 nasuta ....................................... 47, 48, 52, 53

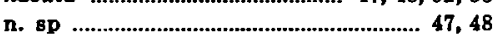

Macoma-Continued secto

58

$47,51,53$

Macrochlamio magnolia ................................ 27

Maestrichtian Stage .................................. 19

Mallory, V. S., cited ...................... 22

Mammuthus imperator .............. 58

Margaritan Stage

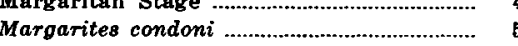

pupillus

Marginulina sp

Marmolejo Formation ....................................... 16

Martinez Stage .......................................... 16, 18

Martinottiella eocenica ................................... 22

McCool Ranch oil field

Megasurcula n. sp. aff.

$$
\text { M. wynoochensis }
$$

51,52

Mesalia martinezensis

Metamorphic rocks

Middle Fork .................................................. 47

Miltha

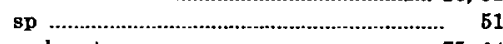

Mineral water ................................................. 75, 81

Mines ................................................... 75

Miocene sediments .................................. 71, 72, 73

Miocene series .......................................... 24

Mitrella sp ................................................... 52, 53

Modiolus sp ............................................. 48, 52, 63

Mojave Desert ................................................... 14

Monarch Peak quadrangle ..............................

Monroe Canyon …......................................... 78

Monroe Swell oil field ...................................... 67, 78

Monterey

Monterey County

Monterey Formation ................... 25, 28, s1, 55, 71

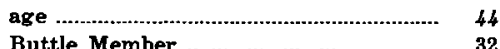
Buttle Member …....................................... 32

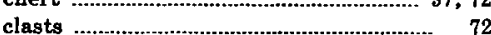
deposition ................................................. 39, 41, 44 diatomaceous rocks .............................. $s 7$ distribution ............................................. 25, 32 dolomite ............................................ $s 7$ fossils ................................................. 41, 44 Hames Member ................................ 28, 32, 35 lithology ............................................. 32, 35 members ….............................................. $s 1$ mudstone ............................................ $s 7,51$ nomenclature ........................................... $s 1$ oil .

phosphate ........................................................... 81, 82

phosphorite

porcelaneous rocks ................................ $\$ 5,49$

sand and gravel ........................................ 82

Sandholdt Member ….................. 28, 30, 31, 35

sandstone

$39,45,75$

............. 37 stratigraphic relations .. 28, 35, 41, 48, 51, 60 structural features ........................ 60, 61, 63 thickness

volcanic rocks

Monterey sandstone

Monteres Shale

Moore, Ellen, cited …............................................

Moriqui Exploration Lanigan 172 well ........ 78

Mudstone ......................................... 16, 18, 19 , $20,21,24,25,31,35,37,48,50,55$

Murdock Oil Marian 1 well

Mya arenaria

Mylar Quarry ......... 79

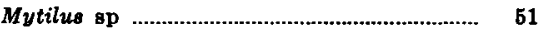
N

Nacimiento Dam

Nacimiento River 58,63 $8,9,11,18,25,29$, $32,39,41,45,46,47,48$, $61,63,75,78,79$

alluvium drainage system ...................................... 74 placer gold
Nassarius $\quad$ Page californianus ............................................ 52 coalingensis ............................................ 53, 54 grammatus ........................................... 53, 54 moranianus ...................................... 54

salinasensis ........................................... 53

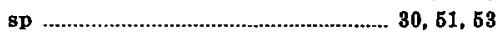

Nattrass Valley quadrangle .......................... 52

Nemocardium linteum ...................................... 18

Nettastomella rostrata ................................. $\quad \mathbf{5 7}$

Neverita 47

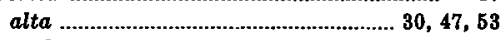

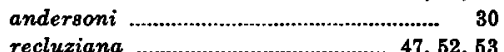
recluziana ................................... 47, 52, 63

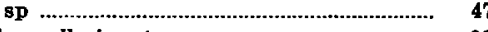

Nodosarella ignota ............................................ 22

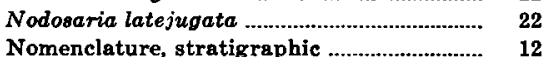

$\begin{array}{ll}\text { Nomenclature, stratigraphic ........................... } & 12 \\ \text { Nomland, J. O., cited } & 54\end{array}$

Nonion costiferum ................................ 42, 43, 44 incisum ....................................................... 43

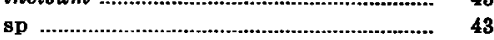

Nonionella miocenica .......................................... 42

Nucella etchegoinensis ................................. 63

Nuculana taphria ............................................

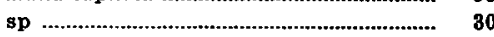

o

Oak Flat

cenebra

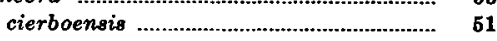

n. sp

tethys …......................................... 52

Oil

$$
\text { sp }
$$

$1,52,53$

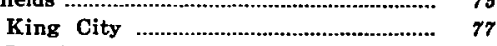

Lynch Canyon ............................................. 78

MeCool Ranch ........................................... 78

Monroe Swell ............................................... 78

Paris Valley ...................................................

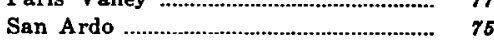

Oligocene series ............................................... 22

Olivella-ischnon ............................................... 30

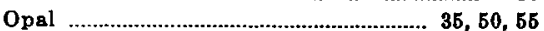

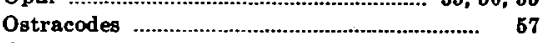

Ostrea atwoodi .................... 51, 52, 53, 54, 57 vespertina sequen ................................. 57

sp …................................................ 19, 53

Oxygen isotope analysis ...................................... $\quad 58$

\section{$\mathbf{P}$}

Pacheco Group

Pacific coast megainvertebrate

sequence ........... 12, 16, 28, 30, 44, 48

Pacific coast provincial chronology .............. 54 Page, B. M., cited ......................................... 65

Paloma fault .............................................. $\quad 70$

Pancho Rico Creek ................................... 9, 48

Pancho Rico Formation ................................ 48

age …...................................................... 44,54

bituminous rock .......................................... 78, 79

conglomerate ........................................... 51

deposition ...................................... 54, 72, 73

diatomaceous rock .................................. 80

distribution

fossils

lithology

mudstone ................................................. 50

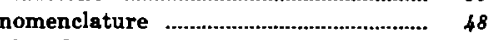

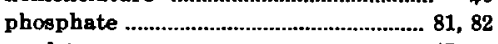

sandstone

45,50

stratigraphic relations ......... $32,45,51,55,66$

structural features .......................... $60,65,73$ thickness

48
52,78

Pancho Rico Valley quadrangle .................

Panopea abrupta ................................... 47, 52, 63 sp 


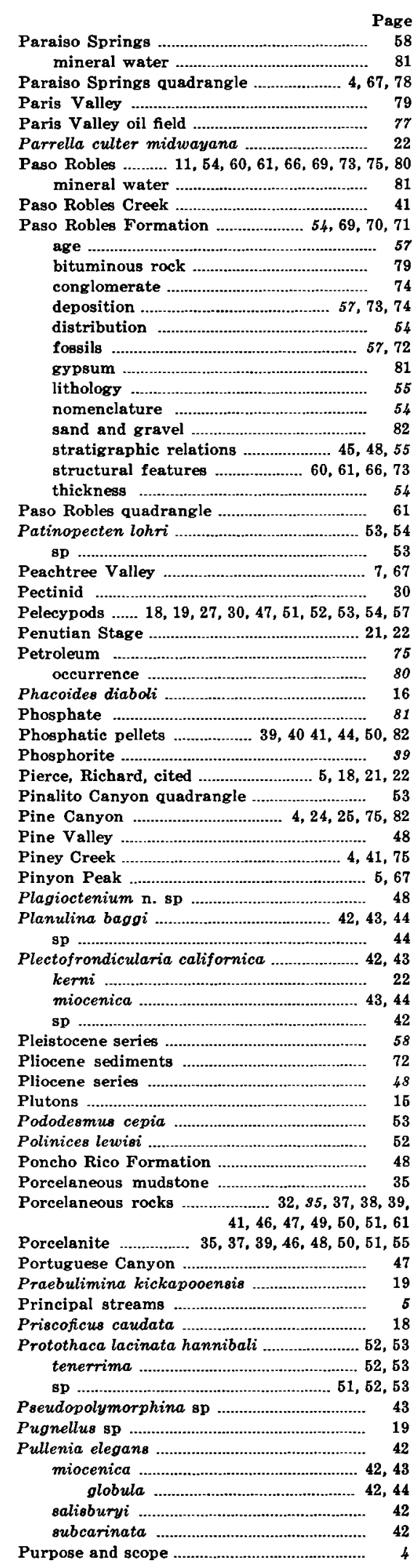

Q

Quarries 81 79 77 22 80
81 57
79 74 74 64 81 55 82 5 22 75 1 22 5

Quaternary system Quinado Canyon

Page 53 2 2

67

4

4

3

4

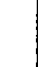

3

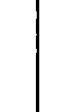

,

R. R. Thorup Thomas Doud Estate 2 …... 77 R. R. Thorup Thomas Doud Estate 3 ........ 77

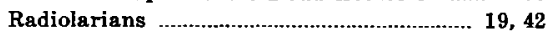
Ranchito Canyon ........................................ 32 Ranchito Canyon quadrangle .... 25, 46, 47, 53, 54

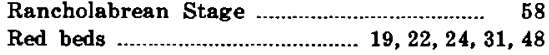
Red beds ................................... 19, 22, 24, 31, 48
References cited ............................. 101 Reliz Canyon ................................ 19, 22, 25, 28, Reliz Canyon $31,32,35,37,44,48,54,70,75$

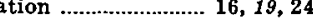
distribution ….......................................... 19 fossils

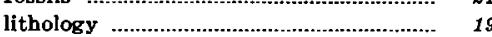
nomenclature 19 stratig raphic relations ......................... 20, 24 thickness …....................................... 19 Reliz Canyon quadrangle ........... 4, 19, 21, 22, 24, $25,32,43,44,50,51,54$, $57,70,75,81,82$ $\begin{array}{lr}\text { Reliz fault } & 70 \\ \text { Relizian Stage } \ldots \ldots \ldots \ldots . . . . . .25,31,41,42,43,44,63,72\end{array}$

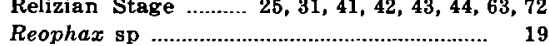
Reserve Oil and Gas Devries 37-25 well ...... 16 Rhabdammina eocenica .............................. 22 Rinconada fault ..................................60, 61, 69 Robulus simplex .......................................... 42 Rock-stratigraphic units ........................................ 12

\section{$\mathbf{S}$}

Saccella sp

Salinas River ............................ 4, 5, 6, 7, 8, 9, 11 , $46,48,49,50,51,54,58,60,61$, $67,69,70,73,74,75,77,78,82$

drainage system

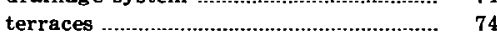
Salinas River valley .................................... 70, 74 Salinas shale ……...................................... 31 Salinas Valley ............................ 31, 48, 70, 74, 80 Salinas Valley area, southern ........ 2, 4, 5, 12, 16 , $45,54,58,60,71,75,80,81$ southern, strain analysis ................... 73 Salinian block …......... 12, 58, 60, 63, 67, 71, 72 Sam Jones fault zone ................................. 60.67 San Andreas fault zone …................. 4, 7, 46,

displacement $58,60,67,71,72$ San Antonio Dam ........................... 47, 58, 61, 82 San Antonio fault .................................. 61, 70 San Antonio River ................. 4, 5, 7, 8, 9, 11, 12 , $21,25,28,30,37,41,45,46$, $48,60,55,60,61,70,73,75,79$

alluvium ............................................... 82 drainage system ….............................. 74, 75

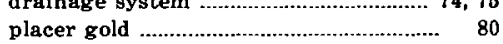
San Antonio River valley .......................... 54, 55, $60,61,70,73$
San Ardo San Ardo oil field ................. 5, 46, 54, 55, 75, 78 San Ardo quadrangle ......................... 4, 48, 50, 77 San Benito County

San Joaquin Valley

San Lorenzo Creek ... San Lucas ……....................................74, 78, 82 San Lucas quadrangle ........... 4, 48, 51, 54, 67, 77 San Luis Obispo County ................................ 2 San Marcos Creek ......................................... 12, 61 placer gold ........................................ $\quad 80$ San Marcos fault ..................................... 47, 60, 61

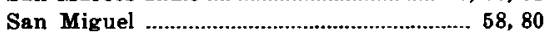
San Miguel quadrangle ........................ 25, 46, 57 San Pablo Formation ..................................... 48 Sand ......................................... 78, 82 Sandholdt Formation ...................................... 31
Page 28, 31, 35, 39

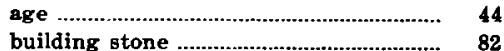
calcareous mudstone ............................ 75, 82 deposition ................................................ 44 dolomite …………..................................... 75, 82 fossils .................................................... 42, 44, 57 lithology ......... 28, 35, 36, 37, 39, 40, 41, 75 pellet phosphate ....................................... 82 stratigraphic equivalent ................ 28, 32, 77 stratigraphic relations ...........................30, 41 structural features .................................. 61, 63 Sandstone $\ldots \ldots \ldots \ldots . . .16,17,19,20,24,25,28,35$, $39,45,46,47,48,50,51,55$ Sandstone dikes ...................................... 39

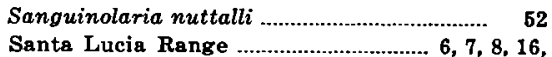
Santa Lucia Range .................... 6, 7, 8, 16, Santa Lueian orogeny ................................ 16 Santa Margarita .......................................... 45, 46 term ….................................................... 46 Santa Margarita Formation …......... 22, 28, 32, 45 age ….......................................... 44, 48, 57 deposition ………................................ 48

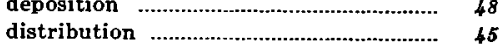

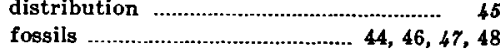

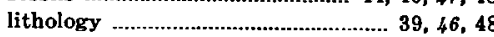
nomenclature ……................................ 45

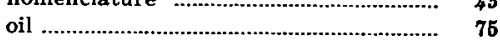

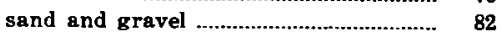
sandstone ......................... 46, 48, 75, 77, 78 stratigraphic equivalent .......... $32,45,75,78$ stratigraphic relations ................. 32, 35, 39, $46,61,55,57$ structural features ..................................61, 65 thickness ……............................................ 45 tuff …...................................................... 82

type area ............................................. 46 Santa Margarita quadrangle ........................ 42, 75

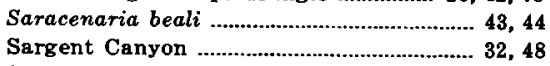
Saucesian Stage ............ 25, 28, 31, 42, 43, 44, 63 Saxidomus sp ................................................

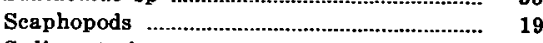
Sedimentation .............................................. 35, 71 Semas Mountain ............................................ 11

Semele sp ..................................................... 53

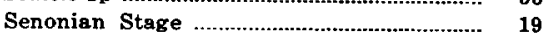

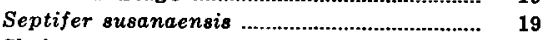
Shale ................................................... $31,48,75$ Shandon quadrangle ....................................... 46 Sheepcamp Creek ....................................... 40 Shell Oil Shell-Texas-Beedy I well ............. 69 Sierra de Salinas ...................... 6, 9, 29, 67, 70 Silicosigmoilina californica ........................... 19 Siliqua sp .................................................. 53, 54 Silt ….............................................................. 68

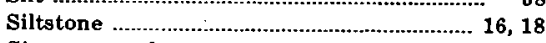
Sinum scopulosum .......................................... $\quad 62$ trigenarium ...................................... 47 Siphogenerina branneri .......................... 42, 43, 44 branneri collomi ...................................... 42 collomi …................................................ 44 hughesi ....................................... 42, 43, 44 kleinpelli ...................................... 42, 43, 44 reedi ........................................................ 42 transversa .................................... 42, 43, 44 Smith, Patsy, cited ............................ 5, 42, 54, 83 Solecurtus gabbianus ................................... $\quad 30$

Solen ........................................................... 19

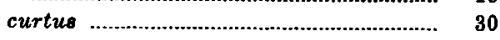

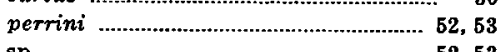
sp ……................................................ 52, 53

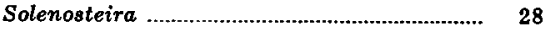
Spiroplectammina chicoana ........................... $\quad 19$ richardi .............................................. 22 sp ............................................................ 44

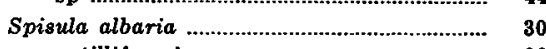

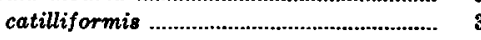

.




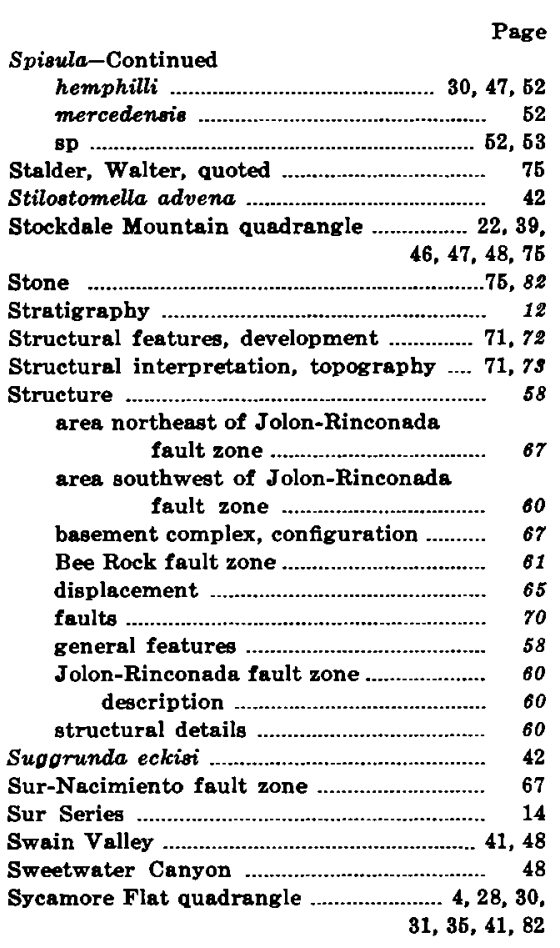

$\mathbf{T}$

Taliaferro, N. L., cited ................................ 16, 18 quoted ......................................... 19, 35, 41 Tar .............................................................. 75, 79

Tellina aragonia .................................. 52 idae .................................................... 52, 53 insurana ............................................. $\quad \mathbf{8 0}$ lutea

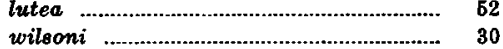

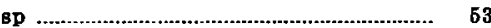

Temblor Group ................................................... 28

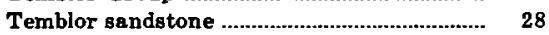

Temblor Stage .................................................... 30, 44 Templeton quadrangle ................... 30, 43, 56, 57, 61 Terebratalia arnoldi ............................ 51, 54, 57 sp ....................................................... 30 Tertiary sea ........................................ 55, 71, 72 Tertiary system …................................ 16, 19, 54 Tessarolax sp ................................................ 19 Texas Beedy (NCT-2) 1 .............................. 78

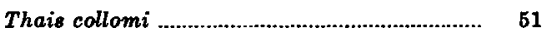
The Rocks Sandstone .................................... 19 Thompson Canyon .................................... 79 Thompson Canyon quadrangle ............. 4, 24, 25, $50,70,77,82$ Thorup, R. R., cited ............................ 19, 22, 24 Tierra Redonda Formation ............... 12, 25, 28, 66

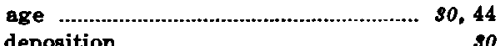
deposition ..... 25,28 distribution ………....................... 29,44

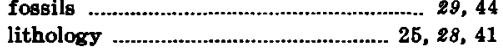
nomenclature ...................................... 28
Tierra Redonda Formation-Continued sand and gravel sandstone stratigraphic equivalent ............... 28, 32, 77 stratigraphic relations ......................... 28, 29 , $35,39,41,60$ structural features ......................... 61, 63, 65 thickness …............................................ 28 type area .................................................. 28, 29 type locality -................................... 28 Tierra Redonda Mountain .................. 11, 25, 28, 29 Tierra Redonda Mountain quadrangle ....... 4, 19, $25,27,37,39,41,47$, $61,63,65,66,70$

Topographic subdivisions ........................ 5 Topography, structural interpretation ...... $7 s$ Tornatellaea pinguis ..................................... 18

Toro Formation …............................................... 16

Trachycardium .................................................. $\mathbf{5 3}$ quadragenarium …........................ 47, 52, 53 vaquerosensis ...................................... 27

Transenella tantilla ...................................... 52 BD ............................................................. 62

Trask, J. B., quoted

Trask, P. D., quoted

Tresus nuttalli

Trifarina advena califormica

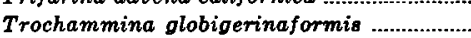

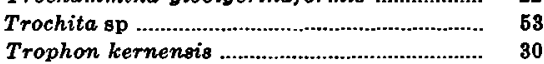

Trophosycon kerniana ............................... 47

Tuff ............................... 41, 46, 47, 75, 82

Tularcitos fault ......................................... 70

Tule Ganyon

Turcica caffea brevio ........................................ 51

Turricula n. sp .............................................. 30 piercei ...................................................... 30, 53

Turritella chicoensis perrini ......................... 18, 19 cooperi ….............................47, 51, 52, 53 gonostoma hemphilli ...................... 47, 62, 53 inezana pervulgata ........................................... 27 infragranulata .......................................... 16, 18 n. sp ( $T$. broderipiana stock) ...... 51, 62, 53 ocoyana .................................................. 30

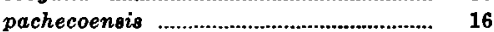

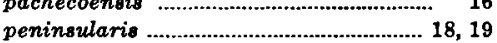
susanaensis .................................................. 16 temblorensis ocoyana ............................... 30 vanvlecki ................................................ 62, 54

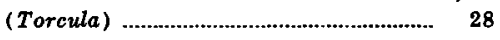

$\mathbf{U}$

Ulatisian Stage …….......................................... 22

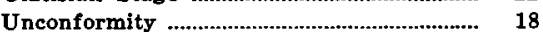

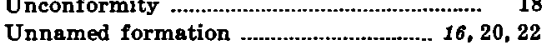
age clasts

deposition . distribution

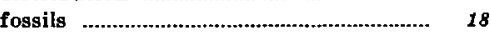
lithology ....................................... 16, 29, 58 stratigraphic relations $18,20,25,29$ structural feature ................................ 60,63

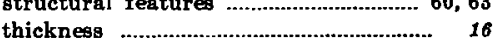

Uvigerina gallowavi hispido-costata
Uvigerina-Continued

hootisi

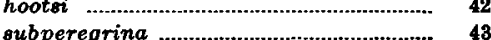

vigerinella californica ............................... 42, 44

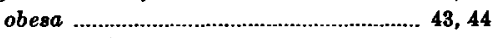

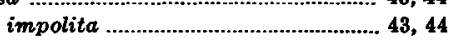

V

Vaginulinopsis asperuliformis ................... 22 Valleton quadrangle ......................... 35, 46, 54, 57 Valvulineria californica ........................ 42, 43, 44 californica appressa .............................. 44

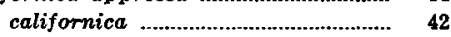
obesa .......................................... 42 casitasensis subcasitasensis ................... 43 depressa .................................. 42, 43, 44 miocenica ....................................................... 42 williami

43,44

Vaquero Sandstone ...................................... 19, 24

Vaqueros Creek .......................... 19, 24, 25, 75, 82

Vaqueros Formation .................................... 22, 24 age …

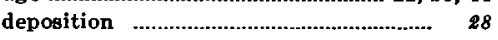
distribution ……...................................... 24, 72 fossils ……...................................... 25,44 lithology ............................................ 25, 28, 29

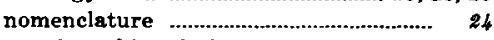
stratigraphic relations ........ 24, 25, 29, 31, 41 structural features ................................... 63 thickness ............................................ 24

Vaqueros Stage ................................. 25, 28, 30, 44

Vaqueros-Temblor sandstone ...................... 28

Venericardia venturensia ............................... $\quad 19$

Ver Planck, W. E., cited ................................. 81

Verneuiliana triangulata .......................................... 22

Vertipecten nevadanus .................................... 27

Vineyard Canyon ......................................... 51, 70

Virgulina bramlettei ................................... 43,44 californiensis .......................................... 42, 43 grandis ................................................ 44

Volcanic ash ............................................ 41

Volcanic rocks $41,51,55$

\section{w}

W. Frank Jones Marport-Ansberry 1 ....... $\quad 77$ Wardle, W. C., cited ..................................... $\quad 22$ Weaver, C. E., cited ................................................... 12

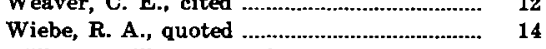
Williams Hill quadrangle ....................... 4, 48, 58 . $60,63,67,82$ Willow Creek fault ........................................ 70 Wilson Corner quadrangle ...................... 28, 30 , $31,35,42,46,47,71,82$

Wunpost quadrangle $41,46,48,62,55,74,75,78$

\section{$\mathbf{Y}$}

Yoldia temblorensis York Mountain quadrangle $41,42,43,82$

$\mathbf{z}$

Zemorrian Stage

Zirfaea pilsbryi

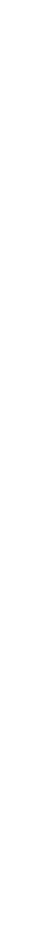






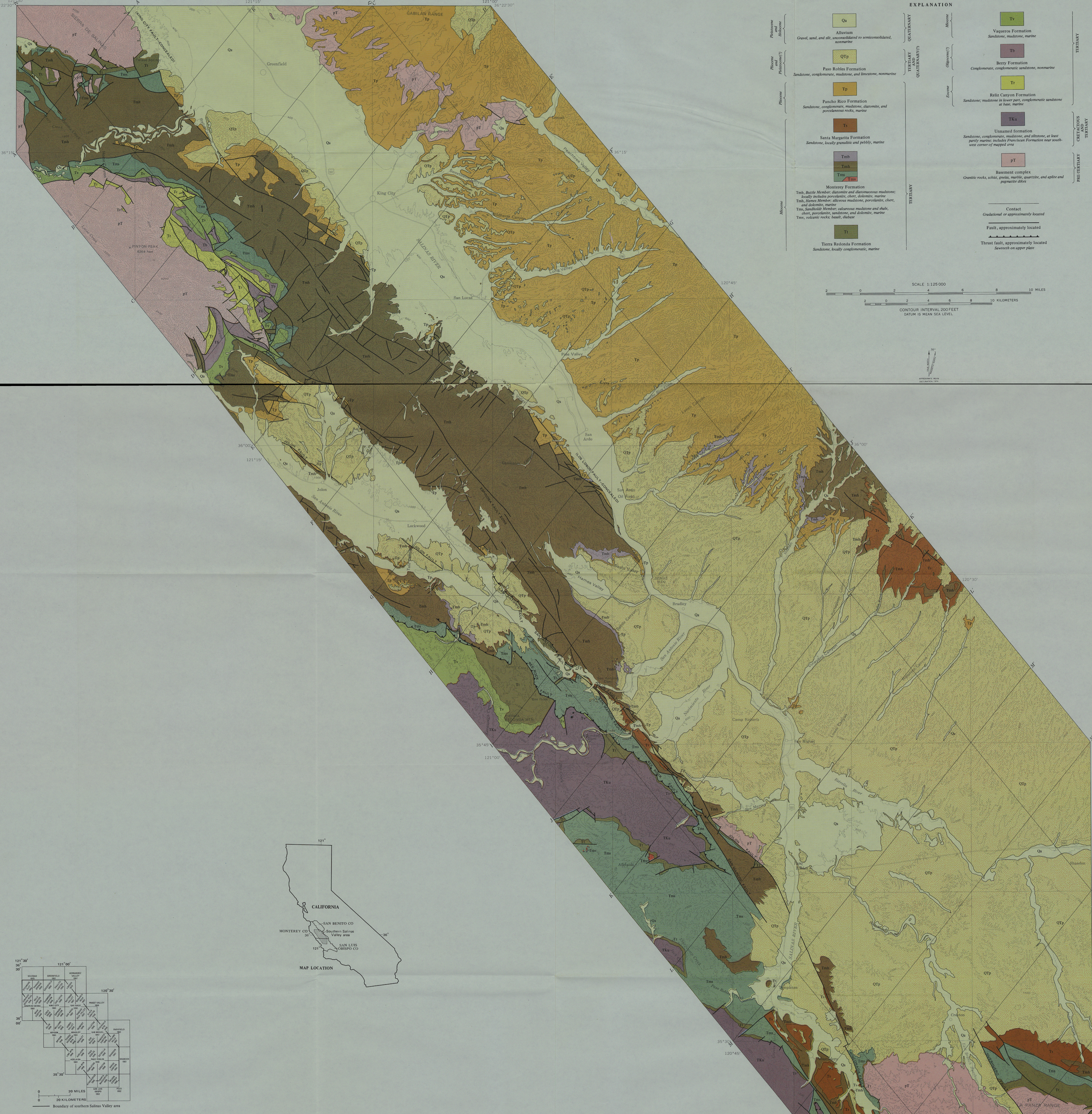



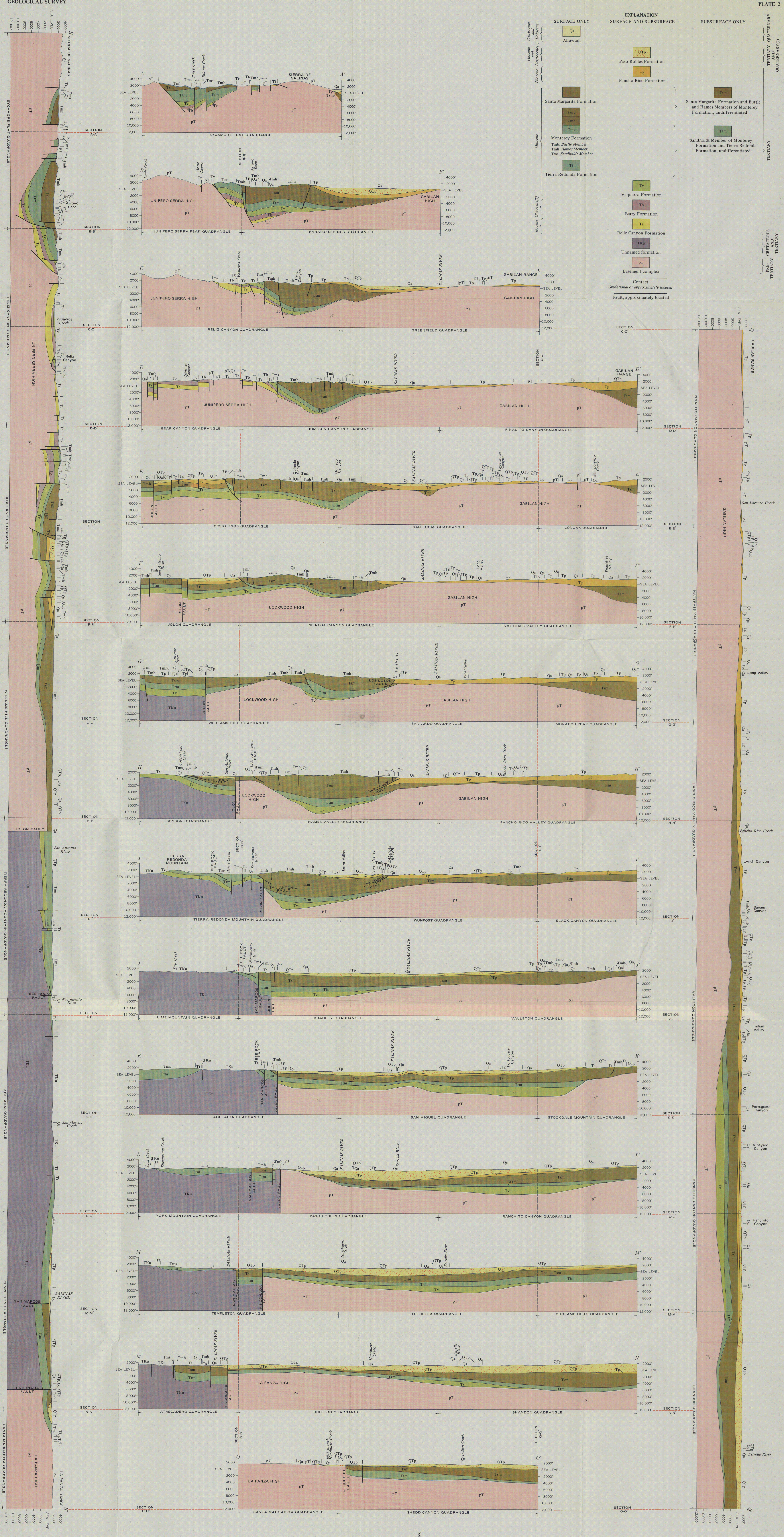

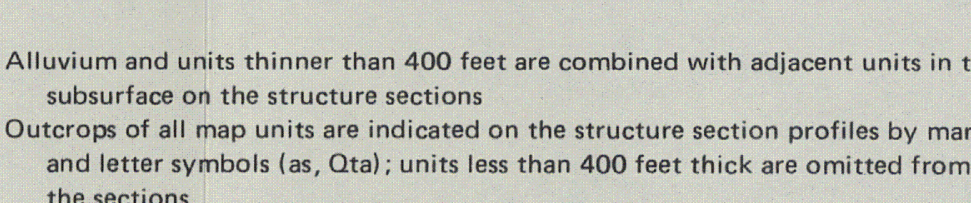

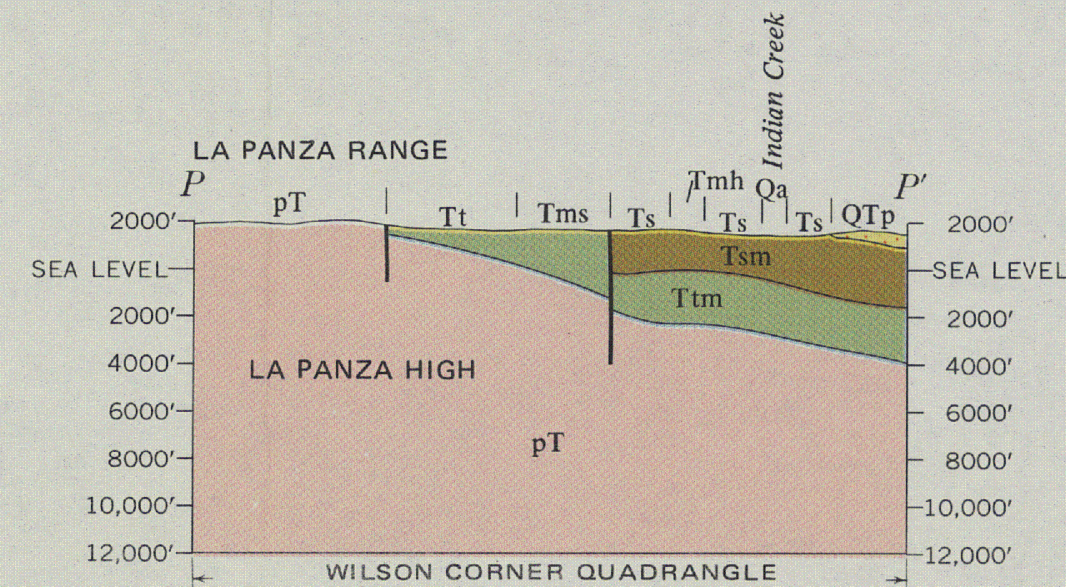





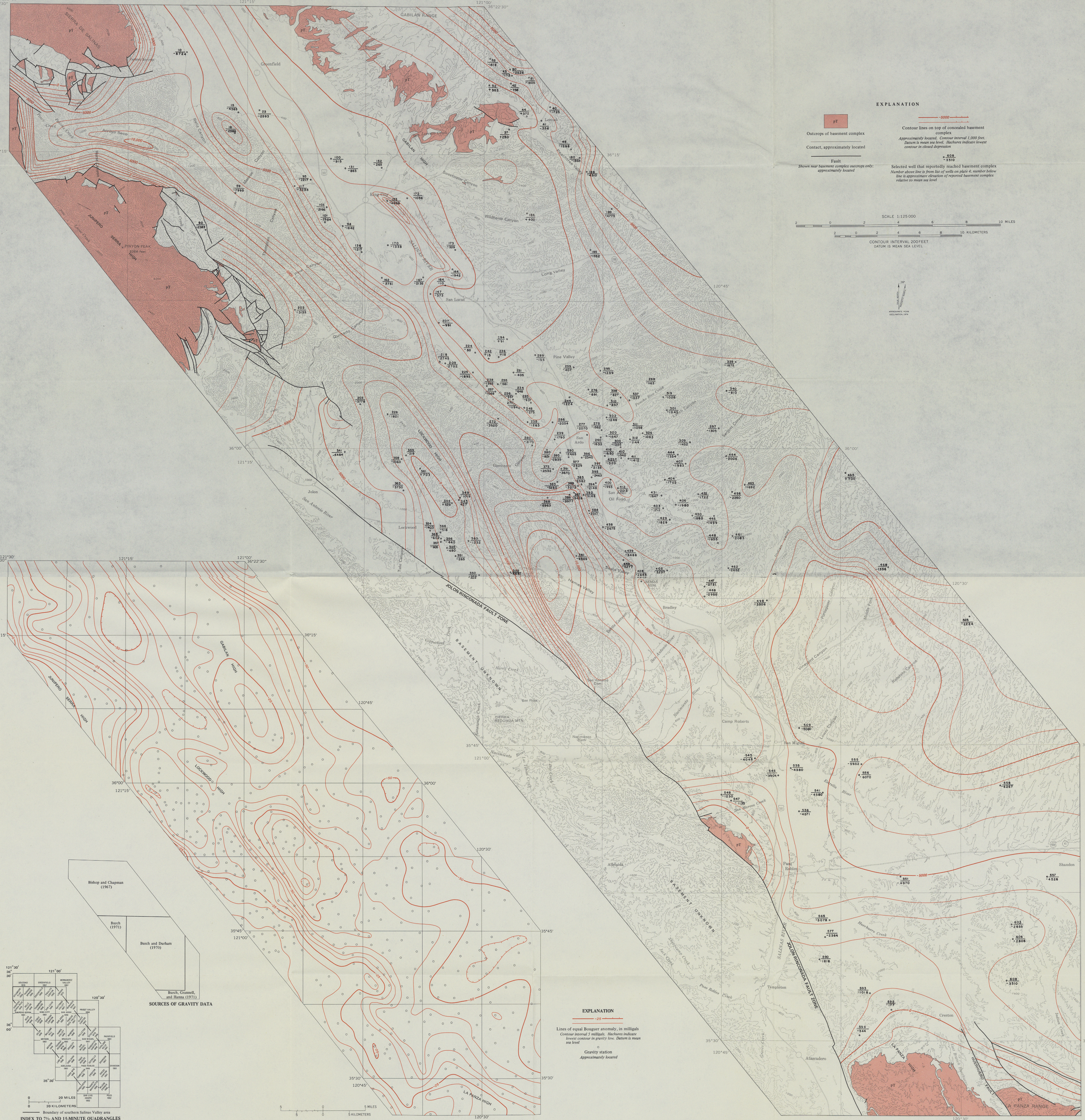



s.
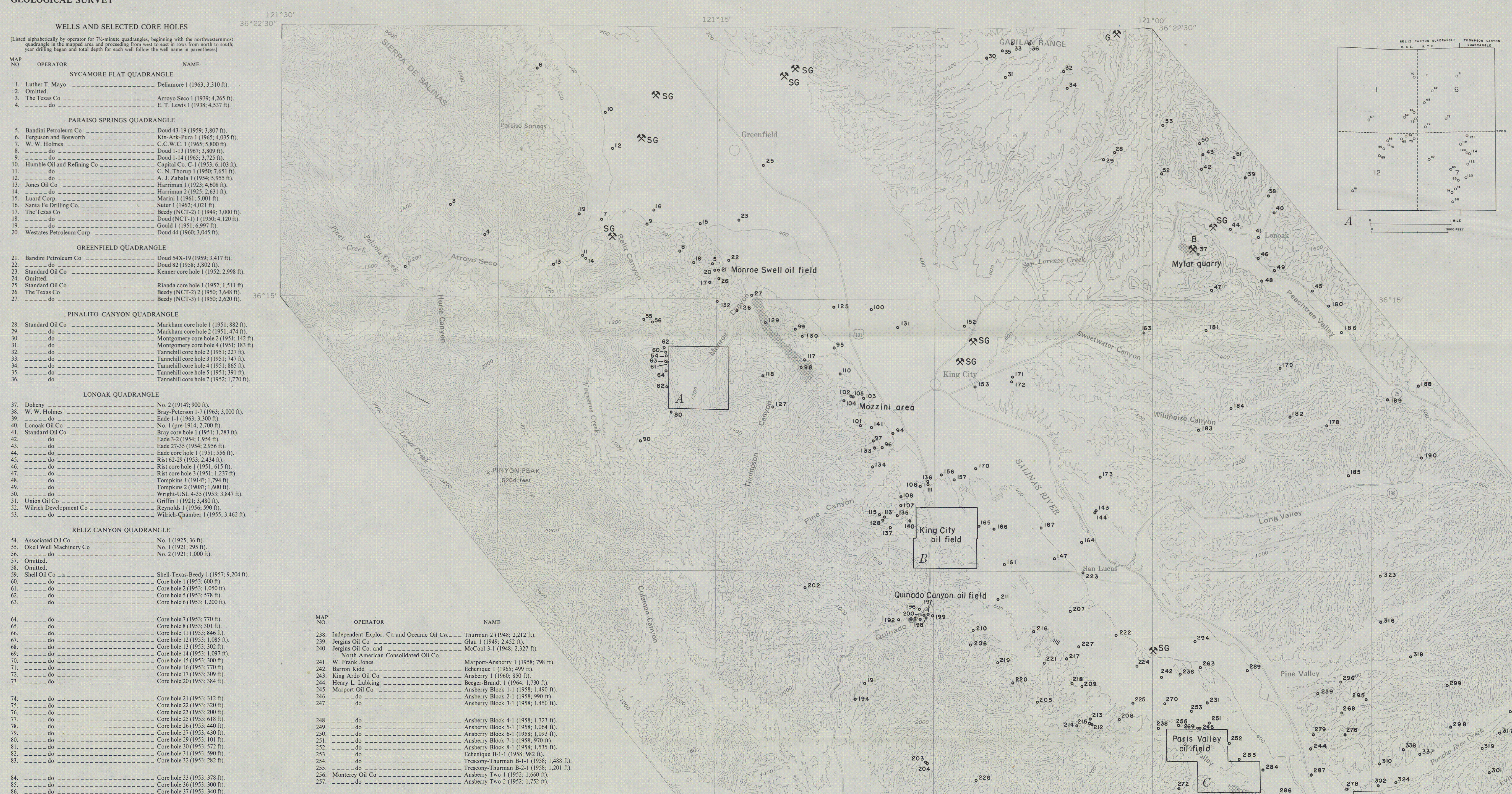

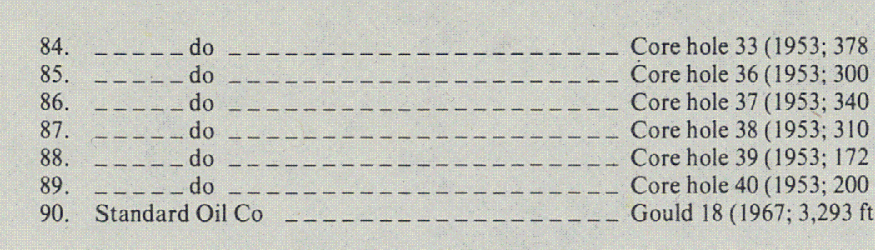

$n=0$
$y=-1$

ba

3
3

b

政

ind

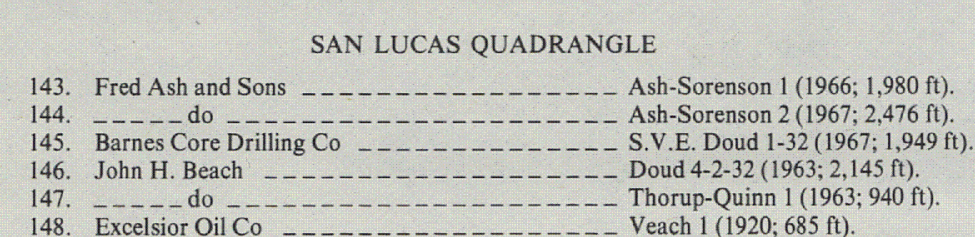

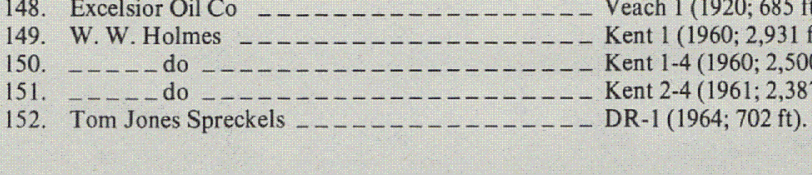

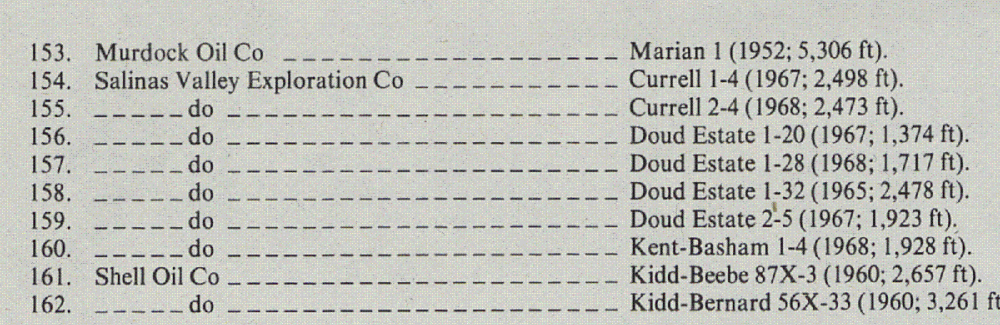

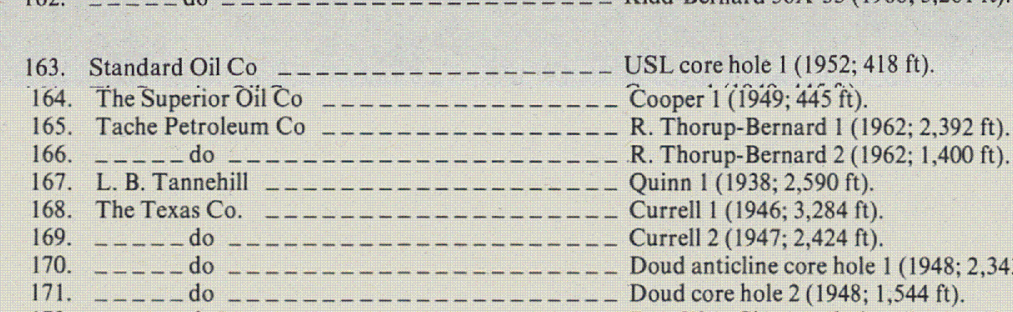

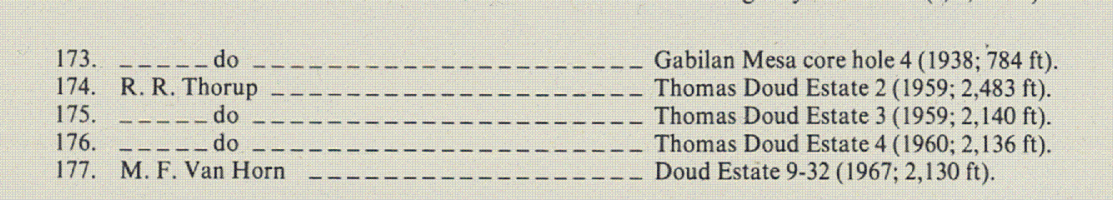

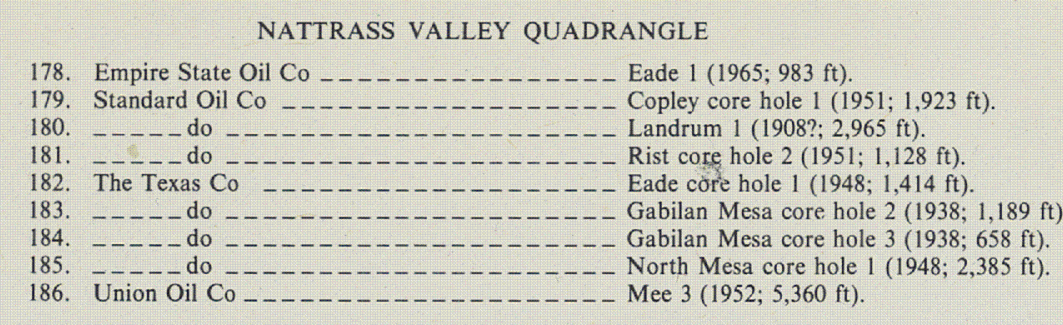

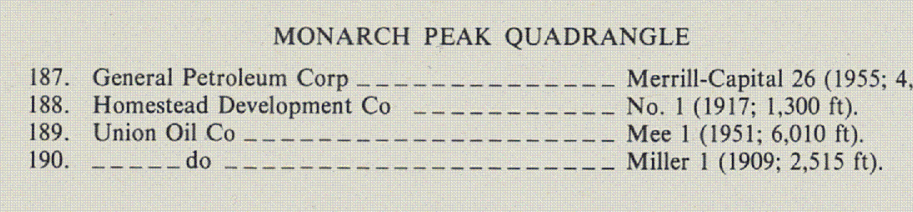

$y^{-5}=$

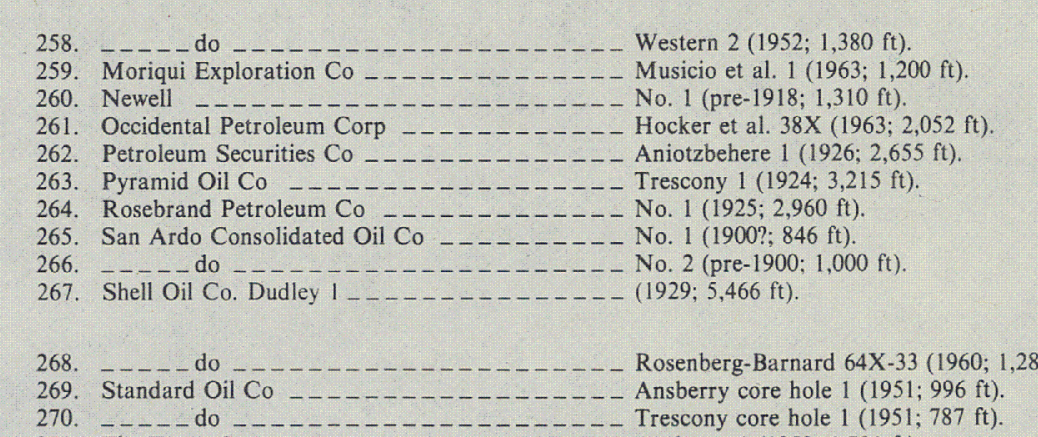

$3 \quad \underline{3}$

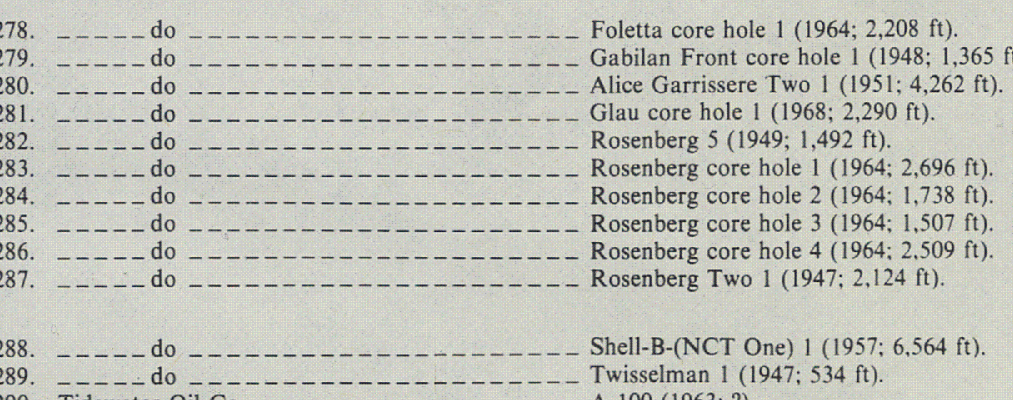

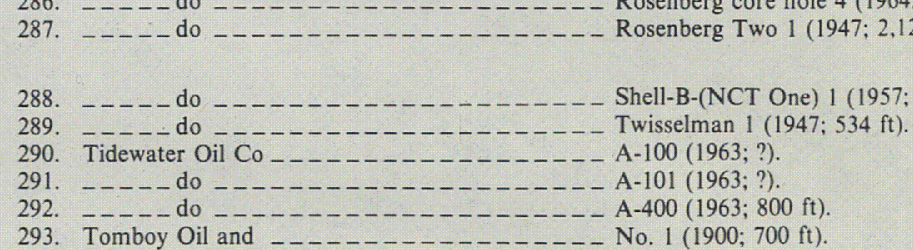

25

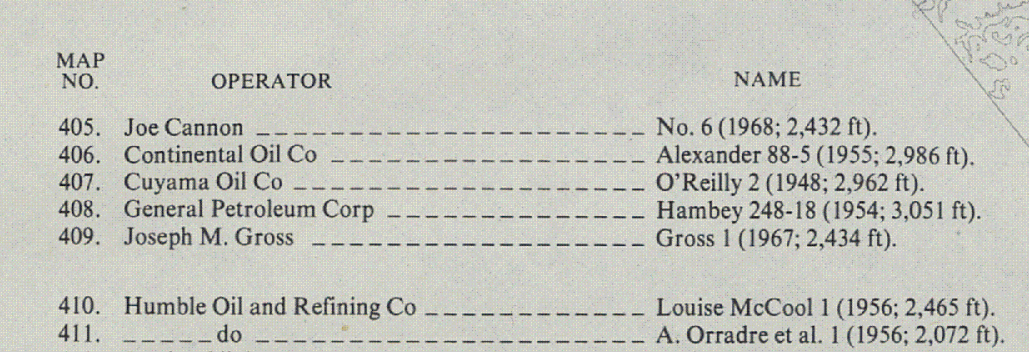

$-3$

$3-\underline{3}=$

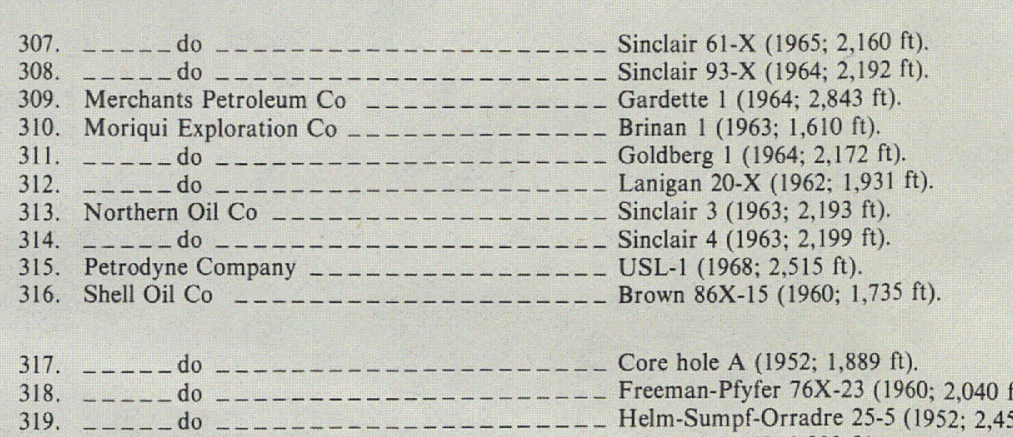

$\sqrt{3}=$

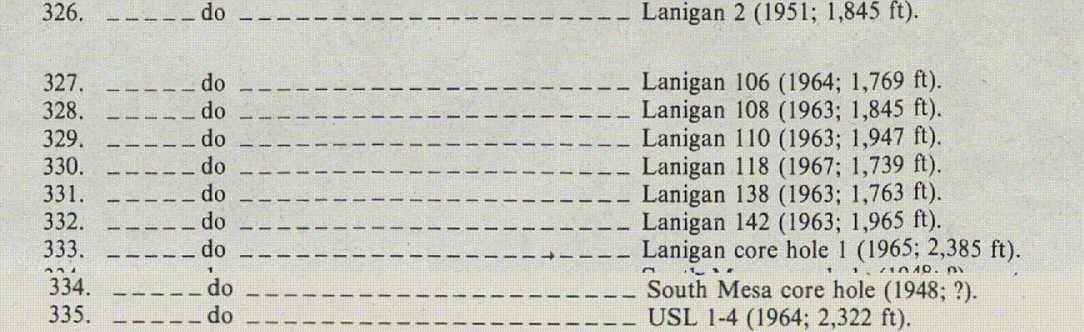

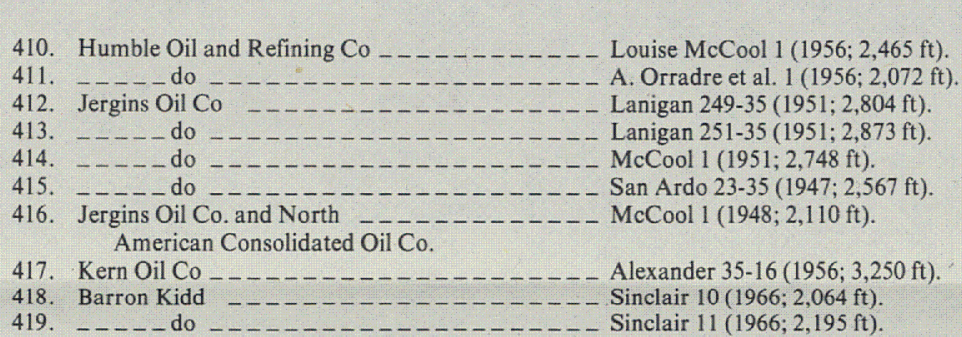

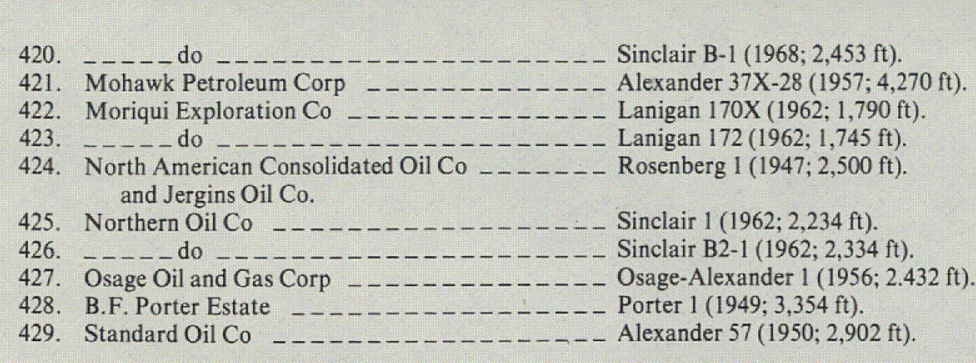

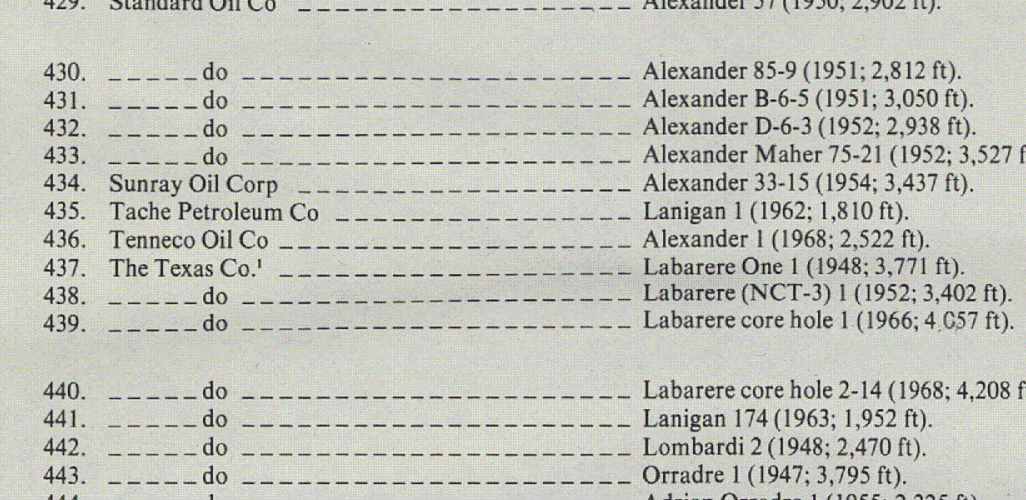

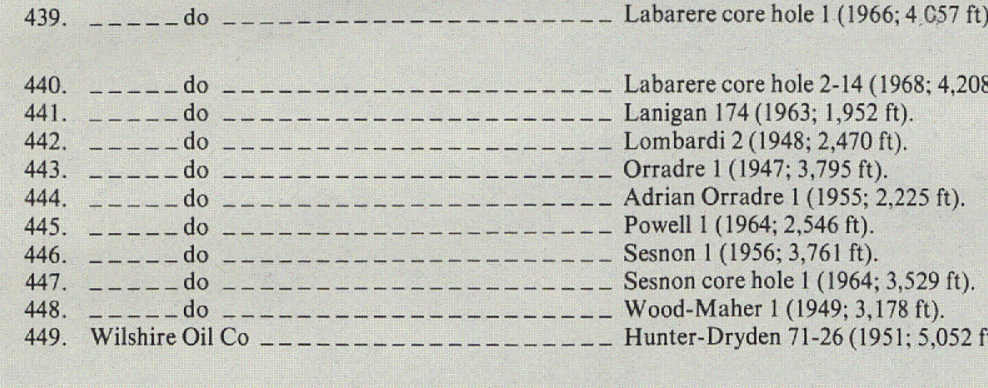

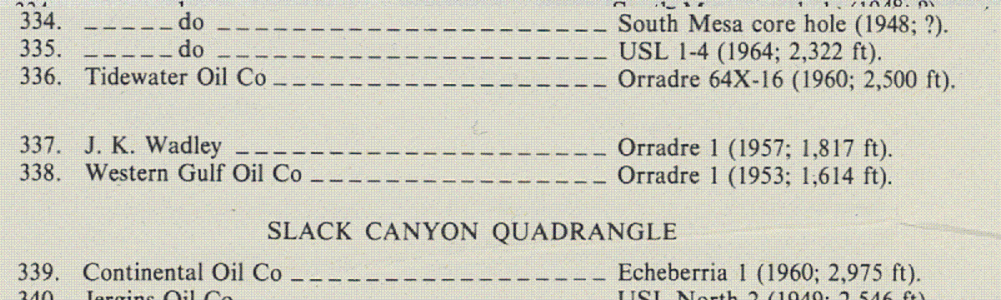

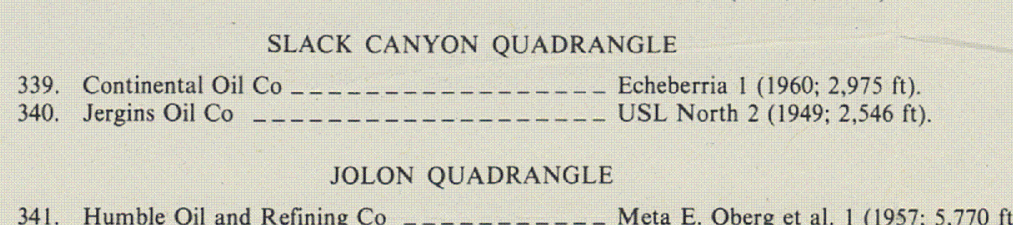

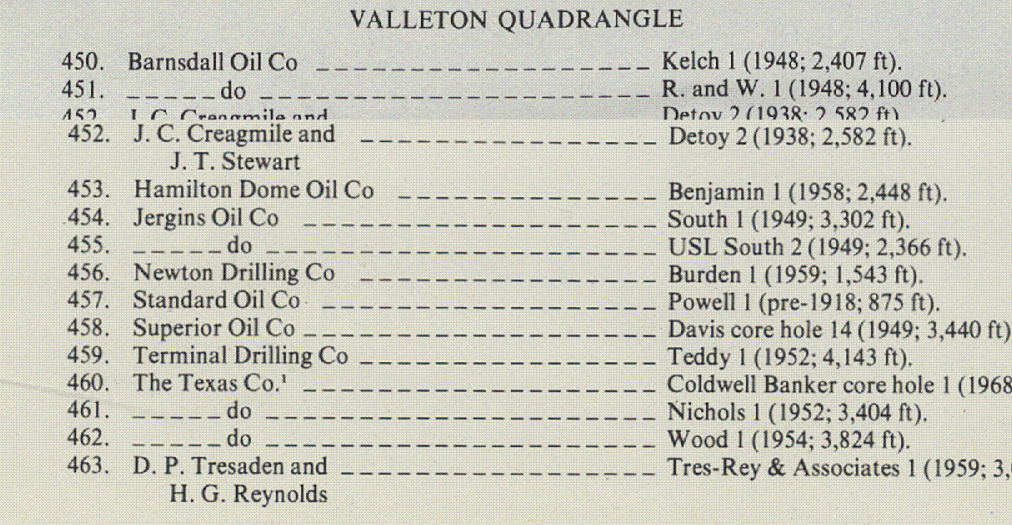

Evis

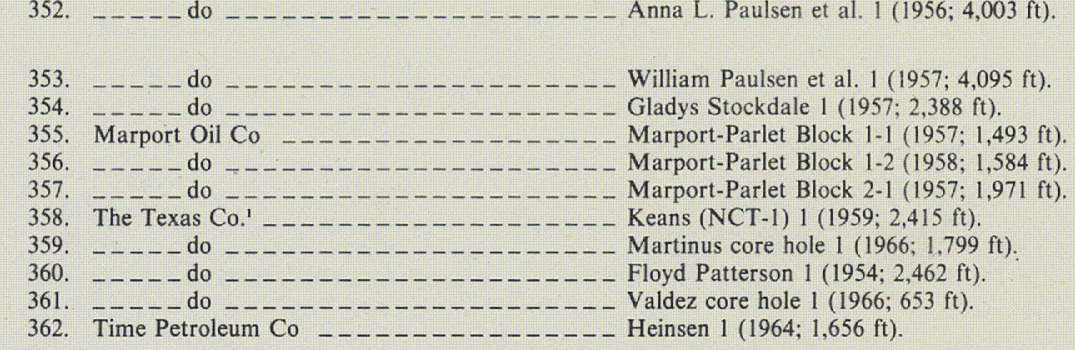

E

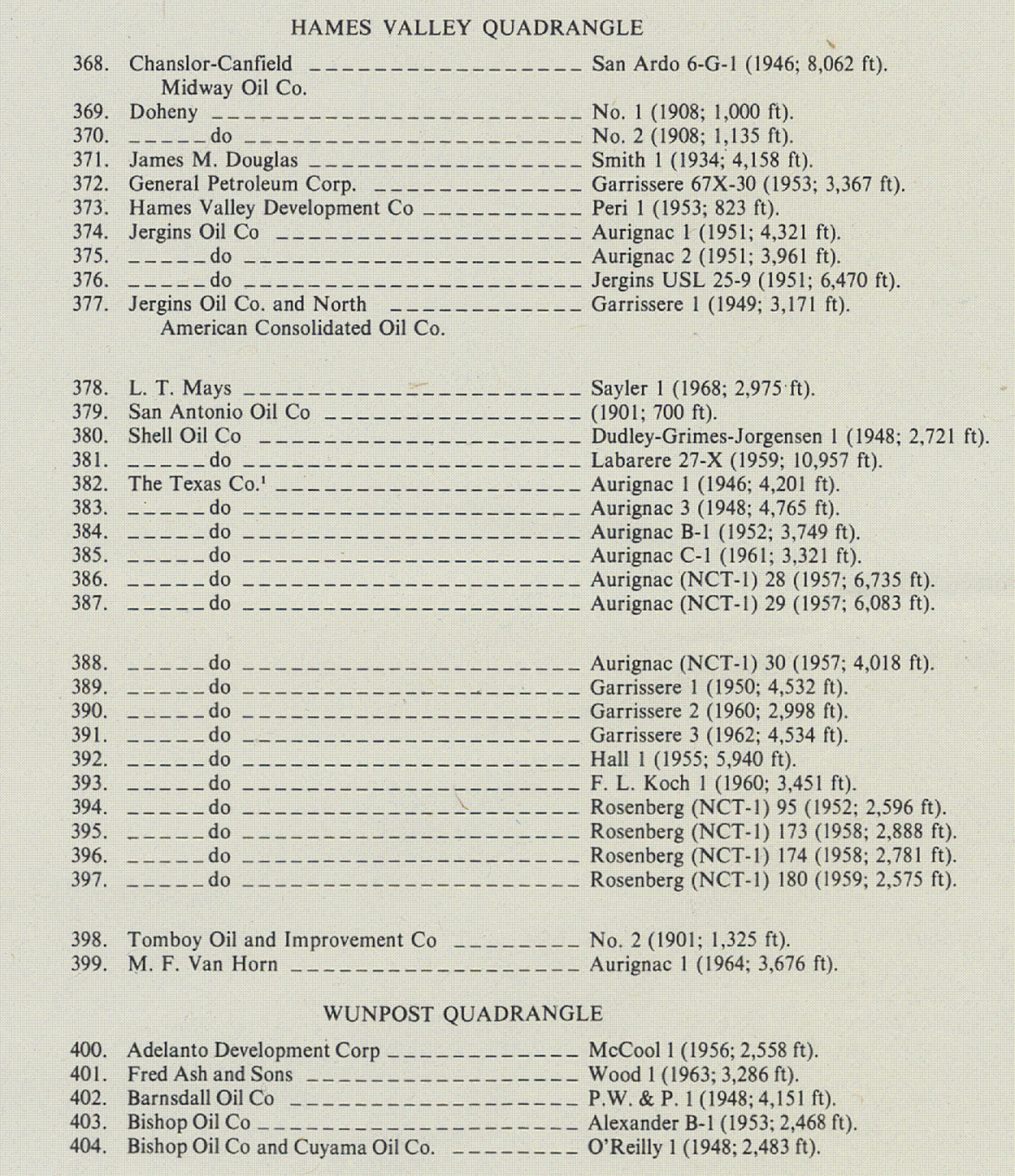

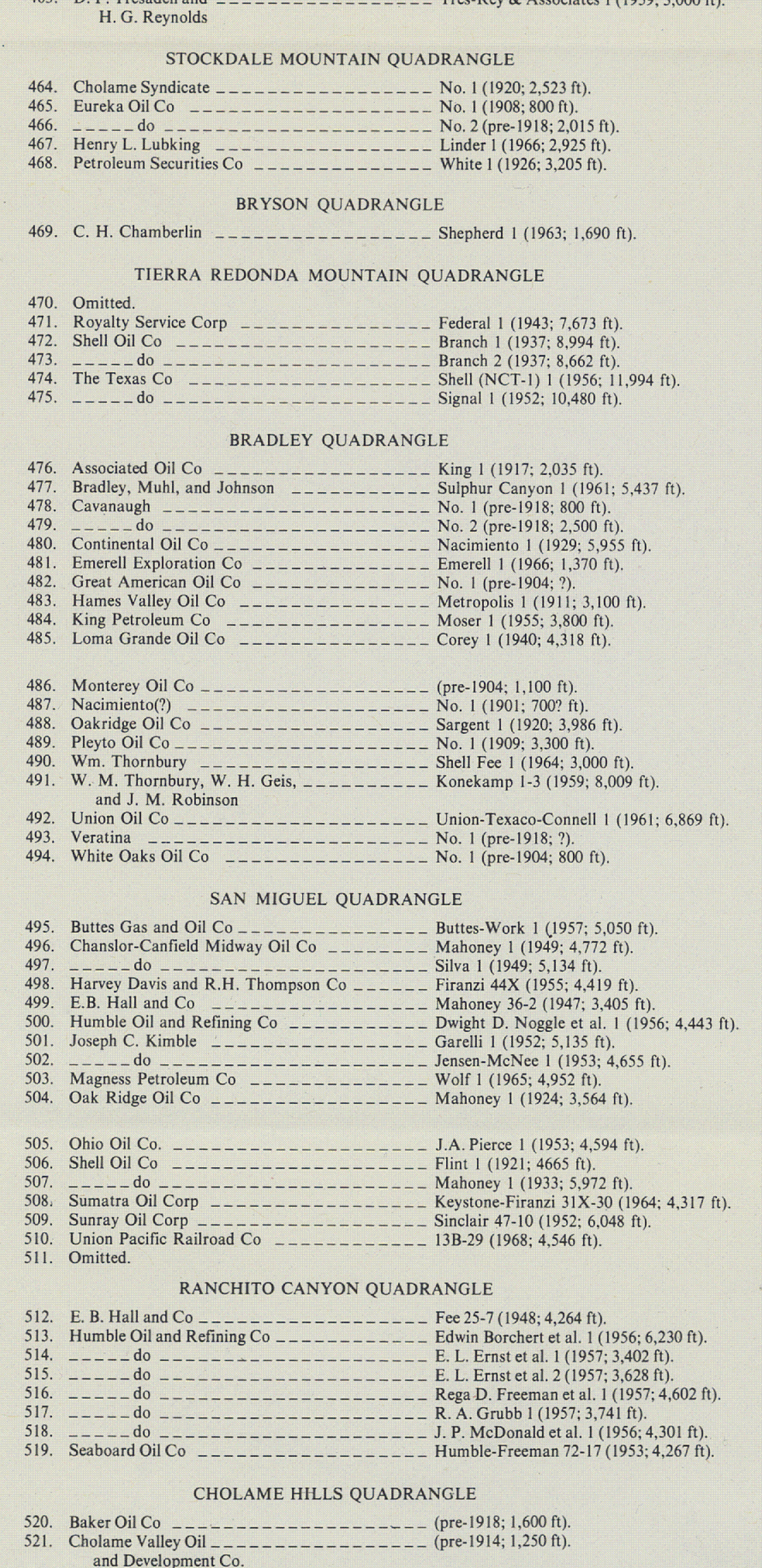
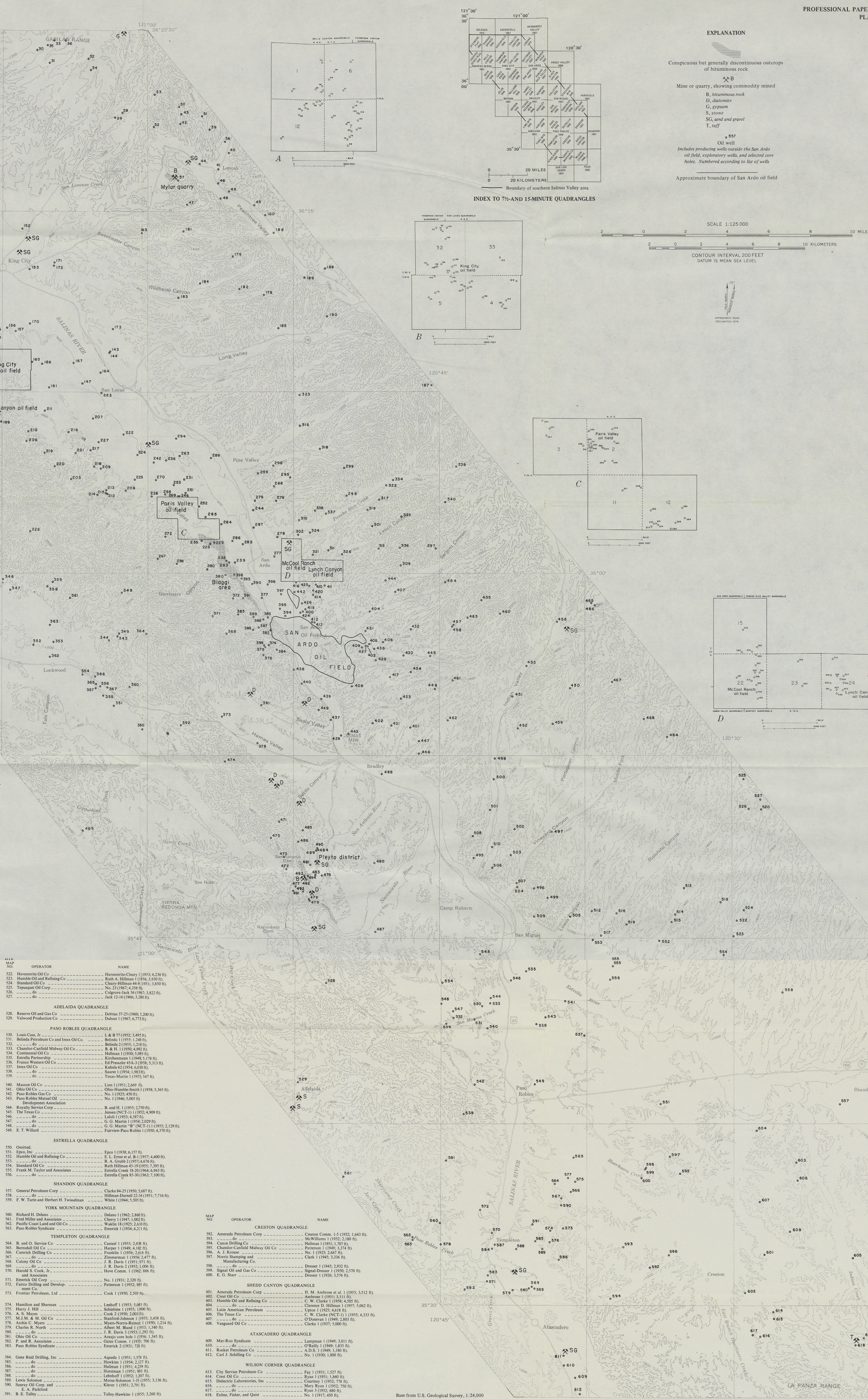

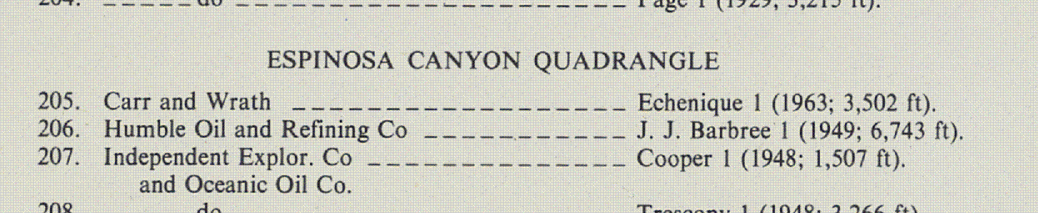

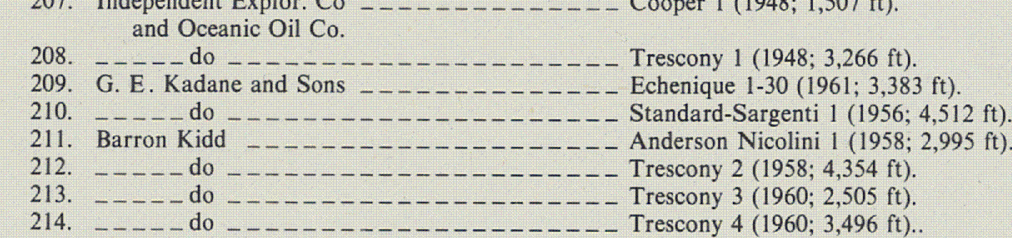

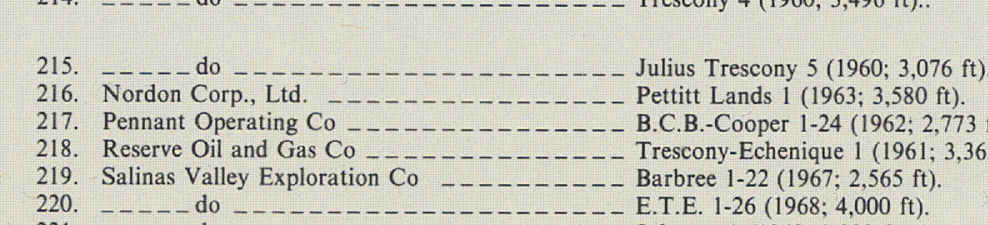

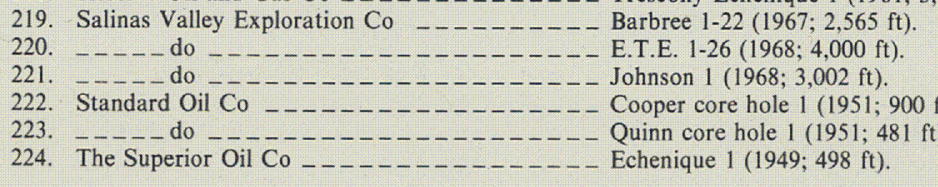

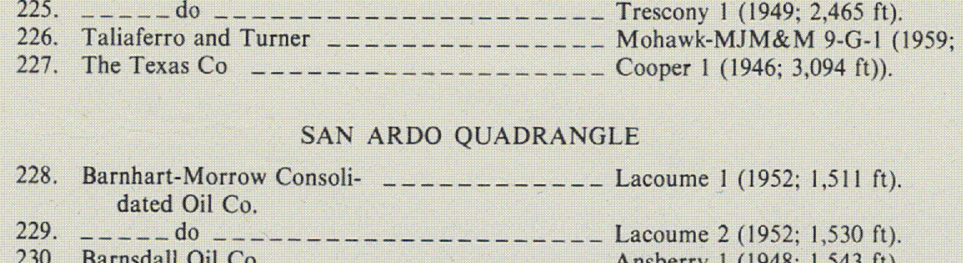

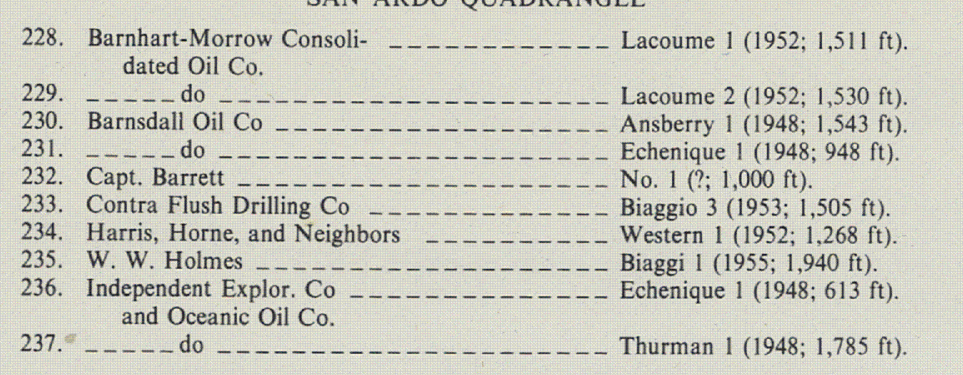



6) 
6) 